\title{
Retention of relict satellite DNA sequences in Anemone (Ranunculaceae)
}

\author{
VIŠNJA BESENDORFER, JELENA MLINAREC* \\ Faculty of Science, University of Zagreb, Division of Biology, Department of Molecular \\ Biology, Horvatovac 102a, HR-10000 Zagreb, Croatia
}

\begin{abstract}
Satellite DNA is a genomic component present in virtually all eukaryotic organisms. The turnover of highly repetitive satellite DNA is an important element in genome organization and evolution in plants. Here we study the presence, physical distribution and abundance of the satellite DNA family AhTR1 in Anemone. Twenty-two Anemone accessions were analyzed by PCR to assess the presence of AhTR1, while fluorescence in situ hybridization and Southern hybridization were used to determine the abundance and genomic distribution of AhTR1. The AhTR1 repeat unit was PCR-amplified only in eight phylogenetically related European Anemone taxa of the Anemone section. FISH signal with AhTR1 probe was visible only in A. hortensis and A. pavonina, showing localization of AhTR1 in the regions of interstitial heterochromatin in both species. The absence of a FISH signal in the six other taxa as well as weak signal after Southern hybridization suggest that in these species AhTR1 family appears as relict sequences. Thus, the data presented here support the »library hypothesis « for AhTR1 satellite evolution in Anemone. Similar species-specific satellite DNA profiles in A. hortensis and A. pavonina support the treatment of A. hortensis and A. pavonina as one species, i.e. A. hortensis s.l.
\end{abstract}

Keywords: Anemone, FISH, library hypothesis, satellite DNA

Abbreviations: FISH - fluorescence in situ hybridization, satDNA - satellite DNA

\section{Introduction}

The genus Anemone s.str. consists of approximately 150 species (TAMURA 1995), mainly distributed in the Northern Hemisphere. The ancestry, phylogenetic differentiation and systematic classification of Anemone have been debated for years. To advance the knowledge of the phylogenetic relationships within Anemone, considerable efforts based on DNA-analytical approach have been applied successfully and provided new insights into interspecific relationships (Hoot et al. 1994, Ehrendorfer and SAMUEL 2001, SchuetTPELZ et al. 2002,

* Corresponding author, e-mail: jelena@biol.pmf.hr

Copyright ${ }^{\circledR} 2013$ by Acta Botanica Croatica, the Faculty of Science, University of Zagreb. All rights reserved. 
EHrENDORFER et al. 2009, MEYER et al. 2010). Hoot et al. (1994) and MEYER et al. (2010) suggest that Hepatica, Knowltonia and Pulsatilla as well as the South American genera Oreithales and Barneoudia should be subsumed within the Anemone s. lat and propose a preliminary classification that recognizes two subgenera (Anemonidium and Anemone), seven sections, and 12 informal subsection groupings. The European Anemone taxa belong to the Anemone section, with only one exception, A. narcissifolia, which belongs to the Anemonidium section. The Coronaria group is the largest in the Anemone section, comprising all the Mediterranean and American tuberous Anemone.

Anemone species were considered favourable plant material in cytogenetic studies because of chromosomal polymorphism, different ploidy levels, as well as variation in DNA content among species (BöCHNER 1945, HEIMBURGER 1959, RothFELs et al. 1966, BAUMBerger 1970, MLinarec et al. 2006, Mlinarec et al. 2012a, Mlinarec et al. 2012b). Following the discovery of differential staining methods such as C-banding in the 1970s, Anemone again became a subject of interest due to the high quantities of heterochromatin and variation in distribution among species (MARKS 1974, MARKS and SCHWEIZER 1974). The greatest variations in heterochromatin amount and distribution on chromosomes are found among the members of the Coronaria group (MLINAREC et al. 2012b).

Satellite DNA (satDNA) is highly repetitive, non-coding and organized into long arrays composed of thousands to millions of tandemly arranged units. These arrays form constitutive heterochromatin (UGARKOVIĆ and PLOHL 2002). Different satDNA sequences can coexist in genomes, forming what has been defined as a library of satDNAs (FRY and SALSER 1977, MEŠTrović et al. 1998). Despite well-recognized roles of telomeric and centromeric satDNAs in the stabilization of chromosome ends and in cell division, their overall biological significance remains unclear (CSINK and HENIKOFF 1998).

Since satDNA evolves through evolutionary processes as predicted by the molecular drive model (DOVER 1986), DNA turnover usually leads to a high interspecific divergence and low intraspecific variation. The balance, persisting between satellite homogenization and persistence of satellite variants, could generate sufficient sequence divergence to cause reproductive isolation between intraspecific lineages, ultimately leading to speciation.

The AhTR1 satDNA monomer is an AT-rich sequence of $560 \mathrm{bp}$; this satDNA sequence constitutes about $0.14 \%$ of the A. hortensis genome, roughly about $3.05 \times 10^{4}$ copies (MLINAREC et al. 2009). The same authors only found evidence of AhTR1 in A. hortensis; the absence of Southern hybridization signals was found in other relatives tested. Here we characterize the presence, genomic distribution and abundance of the AhTR1 in 22 species of Anemone using PCR, fluorescence in situ hybridization (FISH) and Southern hybridization. Our goals were to: $i$ ) evaluate the phylogenetic signal of satDNA family in a genus and ii) gain an insight into the karyotype and genome evolution of Anemone using satDNA markers.

\section{Materials and methods}

\section{Plant material}

Information on all plant taxa used in this study is given in table 1. Plants were grown in pots in the Botanical Garden of University of Zagreb. All species were identified by morphological and karyological characteristics. For karyological studies, actively growing 
Tab. 1. Species and accessions used in this study. The sectional classification is according to MEYER et al. (2010). Positive (+) and negative (-) PCR amplifications of the AhTR1 of the analysed accessions are also reported.

\begin{tabular}{|c|c|c|c|c|}
\hline Taxon & $\begin{array}{l}\text { Accession } \\
\text { No. }\end{array}$ & Origin and/or Source & Section & PCR \\
\hline Anemone apennina $\mathrm{L}$. & 1446B & Dizdarica (Montenegro), & Anemone & + \\
\hline $\begin{array}{l}\text { Anemone blanda Schott et } \\
\text { Kotschy }\end{array}$ & 12418 & BG University of Vienna (Austria) & Anemone & + \\
\hline Anemone coronaria $\mathrm{L}$. & $1725 \mathrm{H}$ & $\begin{array}{l}\text { Anecor, Esdraelo Plain, Tel Shiron, } \\
25 \mathrm{~km} \text { SE of Haifa (Israel) }\end{array}$ & Anemone & + \\
\hline Anemone hortensis $\mathrm{L}$. & $8216 \mathrm{R}$ & Island of Hvar (Croatia) & Anemone & + \\
\hline Anemone palmata $\mathrm{L}$. & 12434 & Morgion, Marseille (France) & Anemone & + \\
\hline Anemone pavonina Lam. & 12724 & Bogdanci, Plajurci (Macedonia) & Anemone & + \\
\hline Anemone ranunculoides $\mathrm{L}$. & 289 & Delibatska peščara (Serbia) & Anemone & + \\
\hline Anemone sylvestris $\mathrm{L}$. & 1451B & Čučerje, Medvednica (Croatia) & Anemone & + \\
\hline Anemone parviflora Michx. & 20081630 & RBG Edinburgh (UK) & Anemone & - \\
\hline Anemone obtusiloba D. Don & 19861079 & RBG Edinburgh (UK) & Homalocarpus & - \\
\hline $\begin{array}{l}\text { Anemone demissa Hook et } \\
\text { Thomson }\end{array}$ & 19910632 & $\begin{array}{l}\text { Upper Mo Chu Dist. (Bhutan), } \\
\text { RBG Edinburgh (UK) }\end{array}$ & Homalocarpus & - \\
\hline $\begin{array}{l}\text { Anemone rivularis } \\
\text { Buch.-Ham. }\end{array}$ & 28070 & $\begin{array}{l}\text { Himalaya (Nepal), } \\
\text { RBG Kew (UK) }\end{array}$ & Rivularidium & - \\
\hline $\begin{array}{l}\text { Anemone hupehensis } \\
\text { Lemoine }\end{array}$ & 28069 & $\begin{array}{l}\text { Sichuan, Huangtuliang Hills } \\
\text { (China), RBG Kew (UK) }\end{array}$ & Rivularidium & - \\
\hline $\begin{array}{l}\text { Anemone tomentosa } \\
\quad \text { (Maxim.) C.'Pei }\end{array}$ & 28071 & RBG Kew (UK) & Rivularidium & - \\
\hline Anemone canadensis $\mathrm{L}$. & 28068 & $\begin{array}{l}\text { South Dakota (USA), RBG Kew } \\
\text { (UK) }\end{array}$ & Anemonidium & - \\
\hline Anemone narcissiflora $\mathrm{L}$. & $1864 \mathrm{~L}$ & $\begin{array}{l}\text { Baden-Würtemburg, German Alps } \\
\text { near Beuron (Germany), BG } \\
\text { University of Zagreb (Croatia) }\end{array}$ & Homalocarpus & - \\
\hline Anemone baldensis $\mathrm{L}$. & $698 \mathrm{G}$ & Vácrátót (Hungary), & Anemone & - \\
\hline Anemone trifolia $\mathrm{L}$. & 562 & $\begin{array}{l}\text { Botanical Garden of the } \\
\text { University of Zagreb }\end{array}$ & Anemone & - \\
\hline Anemone cylindrica A. Gray & $6559 \mathrm{~B}$ & Chemnitz (Germany) & Anemone & - \\
\hline Anemone multifida Poir. & 1247 & Chemnitz (Germany) & Anemone & - \\
\hline Anemone nemorosa $\mathrm{L}$. & 558 & Dubravkin put, Zagreb (Croatia) & Anemone & - \\
\hline Anemone virginiana $\mathrm{L}$. & 11838B & $\begin{array}{l}\text { Quebec, Country Deux-Montaignes } \\
\text { (Canada) }\end{array}$ & Anemone & - \\
\hline
\end{tabular}

root-tip meristems were pretreated with $0.05 \%$ colchicine (Sigma-Aldrich Chemie GmbH, Taufkirchen, Germany) for $4 \mathrm{~h}$ at RT, fixed in a solution of ethanol and acetic acid (3:1) for $24 \mathrm{~h}$ at $-20{ }^{\circ} \mathrm{C}$, and stored in $70 \%$ ethanol at $-20{ }^{\circ} \mathrm{C}$ until use. For cloning as well as for Southern hybridization, high quality genomic DNA was isolated from young leaves using the Qiagen mini kit (GmbH, Hilden, Germany) according to manufacturer's instructions. 


\section{PCR amplification and cloning}

PCR amplifications of the satDNA family AhTR1 were carried out in a $50 \mu \mathrm{L}$ reaction mixture containing $10 \mathrm{ng}$ template DNA, $0.4 \mu \mathrm{M}$ of each primer, $200 \mu \mathrm{M}$ dNTPs, $2.5 \mathrm{U}$ GoTaq ${ }^{\circledR}$ DNA Polymerase and corresponding $1 \mathrm{X}\left(1.5 \mathrm{mM} \mathrm{MgCl}_{2}\right)$ Green Reaction Buffer (Promega Cor., Madison, USA), using the primer pairs AhTR1-1 (5'GTGTGAGGTATAACACACTGT 3') and AhTR1-2 (5' TAGTGTTGTGGAATACACATC 3'). After an initial denaturing step at $94^{\circ} \mathrm{C}$ for $3 \mathrm{~min}$, the amplification was carried out in 30 cycles consisting of denaturation at $94{ }^{\circ} \mathrm{C}$ for $1 \mathrm{~min}$, annealing at $54{ }^{\circ} \mathrm{C}$ for $10 \mathrm{sec}$ and primer extension at 72 ${ }^{\circ} \mathrm{C}$ for $1 \mathrm{~min}$ with final extension at $72^{\circ} \mathrm{C}$ for $20 \mathrm{~min}$. Cloning and transformation procedure were carried out using the InsTAclone ${ }^{\mathrm{TM}}$ PCR Cloning Kit (Fermentas GmbH, Germany) or pGEM $^{\circledR}$-T Easy Vector System (Promega, USA) according to the manufacturer's instructions. Sequencing was carried out by Macrogen Inc. (Seoul, Korea).

\section{Sequence alignment and phylogenetic analysis}

The number of AhTR1 clones by Anemone taxa is indicated in table 2. AhTR1 clones of A. hortensis (EU769127-EU769132) were taken from MLinAREC et al. (2009). All sequences obtained in this study are the result of cloning and are deposited in GeneBank under the accession numbers: A. ranunculoides AhTR1 (KC148493- KC148496), A. apennina AhTR1 (KC148497-KC148500), A. sylvestris AhTR1 (KC148501-KC148502), A. coronaria AhTR1 (KC148503-KC148505), A. blanda AhTR1 (KC148506-KC148509), A. palmata AhTR1 (KC148510-KC148514), A. pavonina AhTR1 (KC148515-KC148520). Sequences were aligned with Clustal X v1.81 (ThOMPSON et al. 1997).

The evolutionary history was inferred using the Neighbor-Joining method (SAITOU and NEI 1987). The evolutionary distances were computed using the Kimura 2-parameter model (KIMURA 1980) and are in the units of the number of base substitutions per site. The analysis involved 34 nucleotide sequences. All positions containing gaps and missing data were eliminated. The tree is drawn to scale, with branch lengths in the same units as those of the evolutionary distances used to infer the phylogenetic tree. Evolutionary analyses were conducted in MEGA5 (TAMURA et al. 2011).

Tab. 2. Features of AhTR1 sequences by Anemone species.

\begin{tabular}{lcccc}
\hline \multicolumn{1}{c}{ Taxa } & $\begin{array}{c}\text { Sequence } \\
\text { number }\end{array}$ & $\begin{array}{c}\text { Sequence } \\
\text { length }\end{array}$ & AT \% & $\begin{array}{c}\text { Polymorphic } \\
\text { sites }\end{array}$ \\
\hline Anemone apennina & 4 & $490-494$ & 66 & 104 \\
A. blanda & 4 & $455-458$ & 67 & 41 \\
A. coronaria & 3 & $457-492$ & 65 & 106 \\
A. hortensis & 6 & $489-485$ & 68 & 163 \\
A. palmata & 5 & $385-495$ & 67 & 100 \\
A. pavonina & 6 & $492-496$ & 69 & 139 \\
A. ranunculoides & 4 & $488-495$ & 66 & 84 \\
A. sylvestris & 2 & 496 & 67 & 67 \\
\hline
\end{tabular}




\section{Chromosome preparation and fluorescence in situ hybridization}

Chromosome preparations for FISH are described in MLINAREC et al. (2006). FISH experiments were done according to MLINAREC et al. (2012b). The probes Apav2AhTR1 and Abla3AhTR were directly labelled with Cy3-dCTP (Amersham, GE Healthcare, Little Chalfont, Buckinghamshire, UK) by using a nick-translation kit according to the manufacturer's instructions (Roche Diagnostics GmbH, Mannheim, Germany). After overnight hybridization, slides were given a stringent wash in $1 \mathrm{X} \mathrm{SSC}$. These stringency conditions allowed the target sequences of approx. 56\% homology to remain hybridized (SCHWARZACHER and HeSLOP-HARRISON 2000). The preparations were mounted in Dako Fluorescent Mounting Medium (Dako North America, Inc., CA93013, USA) and stored at $4{ }^{\circ} \mathrm{C}$. Signals were visualized and photographs captured on an Olympus BX51 microscope, equipped with a highly sensitive Olympus DP70 digital camera. An average of 10 well-spread metaphases was analyzed for each individual. Two individuals per taxa were analyzed.

\section{Southern hybridization}

Southern hybridization analyses were performed using Gene Images AlkPhos Direct Labelling and Detection System (Amersham, GE Healthcare, UK). Genomic DNA (gDNA) $(1.6 \mu \mathrm{g})$ was digested over night with EcoRV (New England Biolabs, Ipswich, USA). Digested gDNA was loaded per lane on a $1 \%(\mathrm{w} / \mathrm{v})$ agarose gel and electrophoretically separated for several hours at $100 \mathrm{~V}$. DNA was blotted onto a positively charged nylon membrane (Roche, Basel, Switzerland) for one hour by using the Model 785 Vacuum Blotter (Biorad, Hercules, USA). Crosslinking was performed for $3 \mathrm{~min}\left(0.24 \mathrm{~J} \mathrm{~cm}^{-2}\right)$ on an UVlink CL508M crosslinker (Uvitec, Cambridge, UK). The membrane was prehybridized for half hour and hybridized over night at $55^{\circ} \mathrm{C}$ using the probe Apav2AhTR. Subsequently, the membrane was washed at $55^{\circ} \mathrm{C}$ and room temperature according to manufacturer's instructions.

\section{Results}

\section{PCR amplification of the AhTR1 satellite family in Anemone}

To detect the presence of AhTR1 satDNA family we performed PCR amplification in Anemone. The AhTR1 repeat unit was amplified in 8 of 22 Anemone taxa. All eight species in which the AhTR1 was amplified were phylogenetically related, belonging to the Anemone section. Six of the eight taxa were members of the Mediterranean group Coronaria $(A$. apennina, A. blanda, A. pavonina, A. palmata, A. hortensis and A. coronaria). Surprisingly, AhTR1 was amplified in A. sylvestris and A. ranunculoides, members of the Multifida and Nemorosa groups, respectively, but not in their closest relatives. As expected, successful PCR amplification usually resulted in a ladder pattern of products (data not shown), suggesting that the AhTR1 family exhibits a tandem repeat organization in the genome.

\section{Sequence analysis}

To investigate diversity of AhTR1 satDNA family in Anemone we have sequenced a total of 32 monomeric repeats of the AhTR1 family belonging to a total of eight species of the genus Anemone. Table 2 details for each species the number of repeat analyses, 
monomer length, base composition and polymorphism. The Anemone AhTR1 was 385-496 bp and 65-69\% in A+T content. The number of polymorphic sites ranged from 41-163, being the lowest in A. blanda and the highest in A. hortensis. Percentage similarity across all 32 AhTR1 sequences ranges from 53-99\%. Previously we found that AhTR1 satellite monomer of $A$. hortensis contains a pentanucletide sequence (CAAAA) that may have consequence for chromatin packing and sequence homogeneity (MLINAREC et al. 2009). Here we have found this motif in 26 out of 32 cloned AhTR1 sequences.

\section{Phylogenetic analysis}

To evaluate the phylogenetic signal of satDNA family in a genus we performed analyses with AhTR1 sequences as molecular markers. Un-rooted Neighbor-Joining tree showed

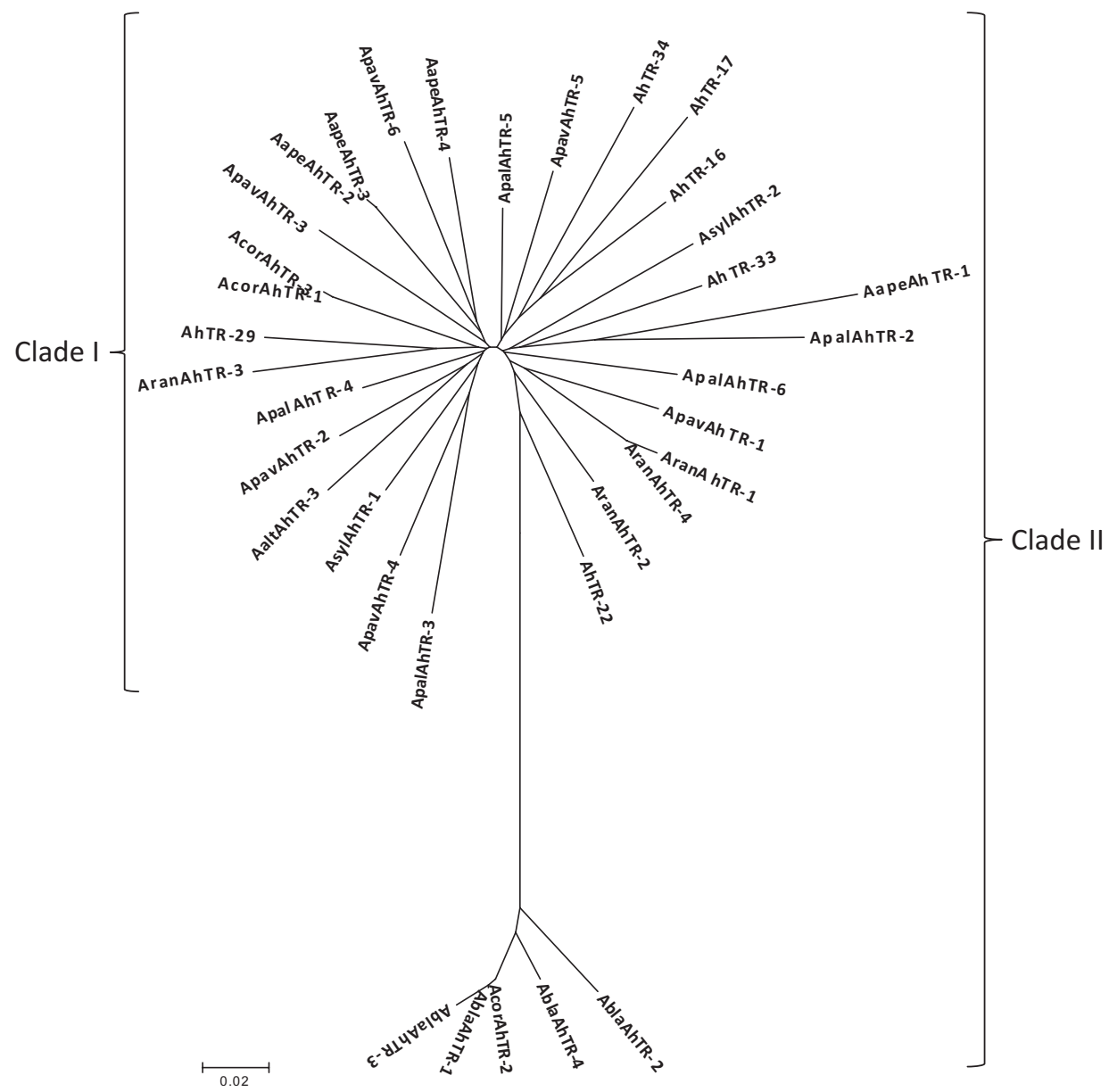

Fig. 1. Phylogenetic relationships among cloned AhTR1 sequences of A. apennina (AapeAhTR1), A. blanda (AblaAhTR1), A. coronaria (AcorAhTR1), A. hortensis (AhTR1), A. palmata (ApalAhTR1), A. pavonina (ApavAhTR1), A. ranunculoides (AranAhTR1) and A. sylvestris (AsylAhTR1). 
separation of sequences into two slightly divergent clades: I and II. The sequences originating from A. coronaria, A. sylvestris, A. apennina, A. palmata, A. hortensis, A. ranunculoides and $A$. pavonina fell within the two distinct clades I and II, while those from A. blanda fell only within clade II (Fig. 1). In both clades the sequences are intermingled. The only exception is $A$. blanda which showed a clear separation within clade II. Interestingly, one clone of $A$. coronaria associated with those of $A$. blanda. For more detailed phylogenetic analyses, more clones should be isolated from each individual.

\section{FISH in Anemone}

Clone Apav2AhTR1 was used as a probe to determine the chromosomal position of AhTR1 satDNA family in the Anemone taxa in which AhTR1 was PCR-amplified. The only exception was $A$. blanda in which clone Abla3AhTR was used as a probe as this species proved to have a distinctive AhTR1 family. The AhTR1 sequences were either completely lacking or predominantly localized at the intercalary DAPI-positive heterochromatic regions of chromosomes. Clear FISH signals were visible only in A. hortensis and A. pavonina (Fig. 2), while negative in situ results were obtained in the karyotypes of other six species in which the AhTR1 was PCR-amplified (data not shown).
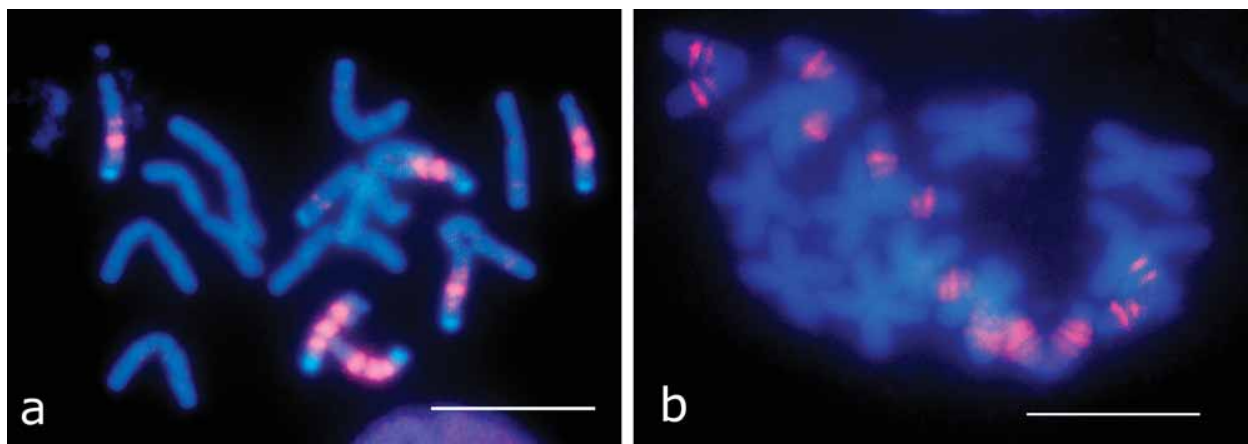

Fig. 2. FISH on mitotic chromosomes of Anemone hortensis (a) and A. pavonina (b) with labelled Apav2JME probe (in red). $B a r=10 \mu \mathrm{m}$.

\section{Southern blot analysis}

To determine the abundance and organization of AhTR1 isolated from A. hortensis within different species of Anemone, clone Apav2AhTR1 was hybridized to EcoRV-digested genomic DNA of A. apennina, A. blanda, A. coronaria, A. hortensis, A. palmata, A. pavonina, A. ranunculoides and A. sylvestris (Fig. 3). In accordance with the FISH experiments, only $A$. hortensis and A. pavonina exhibited a strong ladder-like hybridization signal of similar intensity, suggesting that in these two species satDNA family AhTR1 is highly abundant and represented by a similar copy number. In the lanes of the six other species, the hybridization signal was hardly visible suggesting that in these species AhTR1 is present only as minor repeats. 


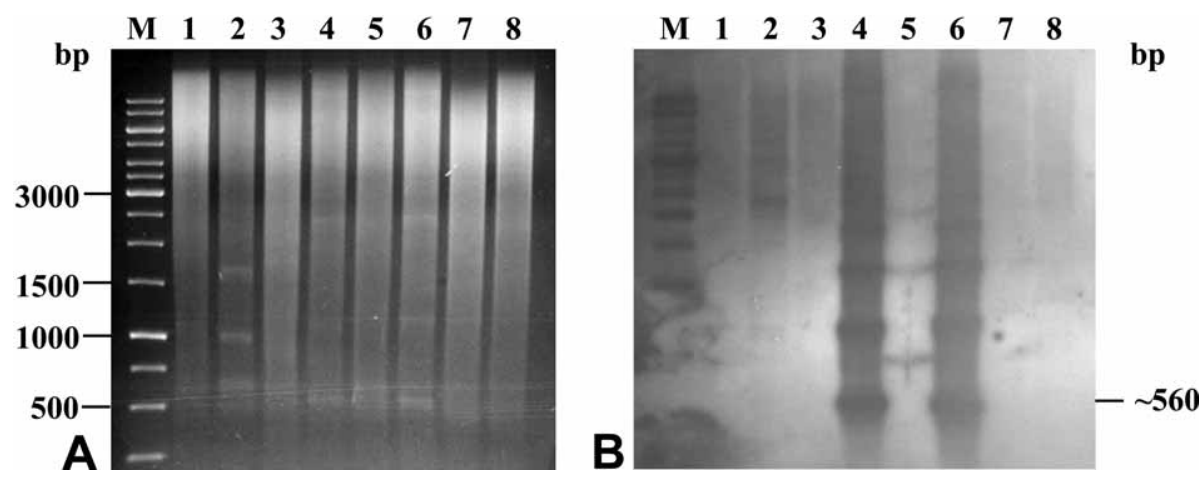

Fig. 3. Genomic restriction digests (A) and Southern blotting analyses (B) of Anemone apennina (1), A. blanda (2), A. coronaria (3), A. hortensis (4), A. palmata (5), A. pavonina (6), A. ranunculoides (7) and $A$. sylvestris (8) with restriction endonuclease EcoRV and probed with clone Apav2AhTR1. M - marker, bp - base pairs.

\section{Discussion}

Distribution of satDNA family AhTR1 is in agreement with phylogeny: the AhTR1 satDNA family is PCR-amplified in the European members of the Anemone section. By contrast, the phylogenetic tree of AhTR1 sequences is not congruent with the phylogeny of these species based on other markers. Using $a t p B-r b c L$ spacer region and ITS data MEYER et al. (2010) demonstrated that Anemone section contains three major clades: a basal clade composed of the members of the Baldensis group; a second clade composed of the members of the Nemorosa and Multifida groups; and a third clade including all tuberous Mediterranean and American Anemone of the Coronaria group. In contrast, the tree based on AhTR1 sequences shows an intermixture of sequences originating from the members of the Coronaria, Nemorosa and Multifida groups with slight divergence of sequences into two clades. The lack of species-specific clustering can be partly explained by divergence of sequences in the ancestors of the species analyzed. However, it is possible that deeper sampling of sequences, within each species, might produce sub-trees that are more representative of species relationships.

In the AhTR1 tree, the only exception is A. blanda, which shows low intra-individual nucleotide diversity and clear separation from the other Anemone taxa in which AhTR1 was amplified. The phylogenetic position of A. blanda has been debated for years. In the tree based on $a t p B-r b c L$ spacer region and ITS data $A$. blanda has a basal position to all anemones of the Anemone section. Thus, the position of A. blanda in the AhTR1 tree agrees with the position based on other molecular markers suggesting that although similar morphological characteristics and geographic distribution unite A. blanda with other Mediterranean anemones in the Coronaria group, this species underwent different evolutionary pathways than the other Mediterranean tuberous Anemone from the Coronaria group.

The DNA library model proposed by FRY and SALSER (1977) hypothesized that closely related species share a set of satellite DNA families (satDNA library) differing in copy number and sequence divergence (UGARKOVIĆ and PLOHL 2002). As a consequence of the 
amplification of a particular satDNA family in a species, this satDNA becomes highly abundant, while the others are present only as minor repeats. This leads to species-specific profiles (Ugarković and PloHl 2002). In Anemone we have found a support for this hypothesis. The presence of AhTR1 in all Mediterranean anemones as well as in the representatives of the other two groups of the Anemone section (the Multifida and Nemorosa groups) suggests that this family was present in the common ancestor of the Anemone section. However, the highly dynamic nature of satDNA turnover resulted in considerable fluctuation in satellite copy number. In A. hortensis and A. pavonina it became highly abundant, while in other members it stayed only as minor repeats, even in the close relative A. coronaria. Furthermore, the AbS1 satDNA family constitutes the major fraction of $A$. blanda interstitial AT-rich heterochromatin, about $2 \%$ of its genome, while in sister species A. apennina the family is present as minor repeats (HAGEMANN et al. 1993). These two satellite DNA families, AhTR1 and AbS1, are highly divergent ( $<35 \%$ similarity) suggesting that in A. hortensis and A. blanda different satDNA families were amplified and became abundant. This further supports the »satDNA library« hypothesis. Besides, it is worth mentioning that in the six species where AhTR1 was present in lower numbers, a ladder PCR pattern was still recovered. The tandem arrangement might be important for maintaining the identity of these repeats via homogenization mechanisms. There are, to our knowledge, few empirical examples for the »satDNA library « hypothesis in plants (KouKALOVA et al. 2010, QueSADA DEL BosQue et al. 2011).

The Mediterranean anemones are mostly diploids (except for A. palmata in which the autotetraploid $2 \mathrm{n}=4 \mathrm{x}=32$ populations are reported, MÉDAIL et al. 2002). The experimental hybrids between A. coronaria, A. palmata and A. hortensis exhibit meiotic asyndesis and are completely sterile (MAÏA and VENARD 1976). As repetitive sequences constitute the major fraction of the genome, it is reasonable to suggest that these are responsive to maintaining reproductive isolation between the Mediterranean Anemone taxa. On the other hand, experimental hybrids between A. hortensis and A. pavonina exhibit relatively normal meiosis and fertility (MAÏA and VENARD 1976). Considering this and the existence of molecular and morphological similarities between A. hortensis and A. pavonina, EHRENDORFER et al. (2009) proposed to treat A. hortensis and A. pavonina as one polymorphic species, i.e. A. hortensis s.l. The results of this study showed that $A$. hortensis and $A$. pavonina share similar species-specific satDNA profile and thus clearly support the treatment of A. hortensis and A. pavonina as one species, i.e. A. hortensis s.l.

In summary, the study of AhTR1 satellite DNA in Anemone reveals a complex evolutionary history where differential levels of satellite DNA amplification in different lineages, at different evolutionary times, and in different chromosomal places gave rise to sequence variants persisting as »library« (MEŠTROVIĆ et al. 1998).

\section{Acknowledgements}

We thank Darko Mihelj for maintaining the plant material and Avionan Danin, Mare Lisičkova, Peter Brownless from RBG Edinburgh and Mario Vallejo-Marin for assistance with the collection of plant material. This work was funded by the Ministry of Science, Education and Sport of the Republic of Croatia, grant no. 119-1191196-1201. 


\section{References}

BAumberger, H., 1970: Chromosomenzahlbestimmungen und karyotypanalysen bei den Gattungen Anemone, Hepatica und Pulsatilla. Berichte der Schweizerischen Botanischen Gesellschaft 80, 17-95.

BöchNER, T. W., 1945: Meiosis in Anemone apennina with special reference to chiasmata localization. Hereditas 31, 221-231.

Csink, A., Henikoff, S., 1998: Something from nothing: the evolution and utility of satellite repeats. Trends in Genetics 14, 200-204.

Dover, G.A., 1986: Molecular drive in multigenes families. How biological novelties arise, spread and are assimilated. Trends in Genetics 168, 159-165.

EHRENDORFER, F., SAMUEL, R., 2001: Contributions to a molecular phylogeny and systematics of Anemone and related genera (Ranunculaceae-Anemoninae). Acta Phytotaxonomica Sinica 39, 293-307.

Ehrendorfer, F., Ziman, S. N., König, C., Keener, C. S., Dutton, B. E., Tsarenko, O. N., Bulakh, E. V., Boscaiu, M., MédaIl, F., Kästner A., 2009: Taxonomic revision, phylogenetics and transcontinental distribution of Anemone section Anemone (Ranunculaceae). Botanical Journal of the Linnean Society 160, 312-354.

FRY, K., SALSER, W., 1977: Nucleotide sequence of Hs- satellite DNA from kangaroo rat Dipomys ordii and characterization of similar sequences in other rodents. The Cell 12, 1069-1084.

Hagemann, S., Scheer, B., Schweizer, D., 1993: Repetitive sequences in the genome of Anemone blanda: Identification of tandem arrays and dispersed repeats. Chromosoma $102,312-324$.

Heimburger, M., 1959: Cytotaxonomic studies in the genus Anemone. Canadian Journal of Botany 37, 587-612.

Hoot, S. B., RezniceK, A. A., Palmer, J. D., 1994: Phylogenetic relationships in Anemone (Ranunculaceae) based on morphology and chloroplast DNA. Systematic Botany 19, 169-200.

KIMURA, M., 1980: A simple method for estimating evolutionary rate of base substitutions through comparative studies of nucleotide sequences. Journal of Molecular Evolution $16,111-120$.

Koukalova, B., Moraes, A. P., Renny-Byfield, S., Matyasek, R., Leitch, A. R., Kovarik, A., 2010: Fall and rise of satellite repeats in allopolyploids of Nicotiana over $c .5$ million years. New Phytologist 186, 148-160.

MaÏA, N., Venard, P., 1976: Contribution a l'étude cytotaxonomique d'espèces Méditerranéennes d'Anemone et de leurs hybrides. Canadian Journal of Genetic and Cytology 18, 151-168.

MARKS, G. E., 1974: Giemsa banding of meiotic chromosomes in Anemone blanda L. Chromosoma 49, 113-119.

MARKs, G. E., SchweIZER, D., 1974: Giemsa banding: karyotype differences in some species of Anemone and in Hepatica nobilis. Chromosoma 44, 405-416. 
Médail, F., Ziman, S., Boscaiu, M., Riera, J., Lambrou, M., Vela, E., Dutton, B., EhrenDORFER, F., 2002: Comparative analysis of biological and ecological differentiation of Anemone palmata L. (Ranunculaceae) in the western Mediterranean (France and Spain): an assessment of rarity and population persistence. Botanical Journal of the Linnean Society $140,95-114$.

Meštrović, N., Plohl, M., Mravinac, B., Ugarković, Đ., 1998: Evolution of satellite DNAs from the genus Palorus-experimental evidence for the »library « hypothesis. Molecular Biology and Evolution 15, 1062-1068.

Meyer, K. M., Hoot, S. B., Arroyo, M. T. K., 2010: Phylogenetic affinities of South American Anemone (Ranunculaceae) including the endemic segregate genera, Barneoudia and Oreithales. International Journal of Plant Sciences 171, 323-331.

Mlinarec, J., Chester, M., Siljak-Yakovlev, S., Papeš, D., Besendorfer, V., 2009: Molecular structure and chromosome distribution of three repetitive DNA families in Anemone hortensis L. (Ranunculaceae). Chromosome Research 17, 331-343.

Mlinarec, J., PAPeš, D., Besendorfer, V., 2006: Ribosomal, telomeric and heterochromatin sequences localization in the karyotype of Anemone hortensis. Botanical Journal of the Linnean Society 150, 177-186.

Mlinarec, J., Šatović, Z., Malenica, N., Ivančić-Baće, I., BeSEndorfer, V. 2012a: Evolution of the tetraploid Anemone multifida $(2 \mathrm{n}=32)$ and hexaploid A. baldensis $(2 \mathrm{n}=$ 48) (Ranunculaceae) was accompanied by rDNA loci loss and intergenomic translocation: evidence for their common genome origin. Annals of Botany 110, 703-712.

Mlinarec, J., Šatović, Z., Mihelu, D., MalenicA, N., Besendorfer, V., 2012b: Cytogenetic and phylogenetic studies of diploid and polyploid members of tribe Anemoninae (Ranunculaceae). Plant Biology 14, 525-536.

Quesada del Bosque, M. E., Navajas-Perez, R., Panero, J. L., Fernandez-Gonzalez, A., GARRIDO-RAMOS, 2011: A satellite DNA evolutionary analysis in the North American endemic diocious plant Rumex hastatulus (Polygonaceae). Genome 54, 253-260.

Rothfels, K., Sexsmith, E., Heimburger, M., Krause, M. O., 1966: Chromosome size and DNA content of species of Anemone and related genera (Ranunculaceae). Chromosoma 20, 54-74.

SaItou, N., NeI, M., 1987: The neighbor-joining method: A new method for reconstructing phylogenetic trees. Molecular Biology and Evolution 4, 406-425.

Schuettpelz, E., Hoot, S. B., Samuel, R., Ehrendorfer, F., 2002: Multiple origins of Southern hemisphere Anemone (Ranunculaceae) based on plastid and nuclear sequence data. Plant Systematics and Evolution 231, 143-151.

Schwarzacher, T., Heslop-Harrison, J. S., 2000: Practical in situ hybridization. Oxford: Bios.

Tamura, K., Peterson, D., Peterson, N., Stecher, G., Nei, M., Kumar, S., 2011: MEGA5: Molecular evolutionary genetics analysis using maximum likelihood, evolutionary distance, and maximum parsimony methods. Molecular Biology and Evolution 28, 27312739. 
BESENDORfer V., MLinarec J.

TAMURA, M., 1995: Angiospermae: Ordnung Ranunculales, Fam. Ranunculaceae, Anemoneae. In: HIEPKO, P. (ed.), Die Natürlichen Pflanzenfamilien 17a, 4, 324-349. Duncker and Homblot, Berlin.

Thompson, J. D., Gibson, T. J., Plewniak, F., Jeanmougin, F., Higgins, D. G., 1997: ClUSTAL-X windows interface: flexible strategies for multiple sequence alignment aided by quality analysis tools. Nucleic Acids Research 25, 4876-4882.

Ugarković, Đ., Plohl, M., 2002: Variation in satellite DNA profiles-causes and effects. The EMBO Journal 21, 5955-5959. 
Acta Bot. Croat. $72(1), 13-22,2013$

\title{
Comparative study of in vitro, ex vitro and in vivo grown plants of Arnica montana - polyphenols and free radical scavenging activity
}

\author{
Milena Nikolova $^{1 *}$, Mariya Petrova ${ }^{2}$, Ely Zayova $^{2}$, Antonina VitKova $^{1}$, \\ LJUBA EvSTATIEVA ${ }^{1}$ \\ ${ }^{1}$ Institute of Biodiversity and Ecosystem Research, Acad. G. Bonchev 23, 1113 Sofia, \\ Bulgaria \\ ${ }^{2}$ Institute of Plant Physiology and Genetics, 21 G. Bonchev Street, 1113 Sofia, Bulgaria
}

\begin{abstract}
Arnica montana L. is an endangered species rich in sesquiterpene lactones, phenolic acids and flavonoids with high pharmaceutical value. The polyphenolic content and free radical scavenging activity of plants that had passed all stages of cultivation: micropropagation and rooting (in vitro), adaptation in greenhouse (ex vitro) and mountain conditions (in vivo) were evaluated. Four surface flavonoid aglycones [scutellarein 6-methyl ether (hispidulin), scutellarein 6,4'-dimethyl ether (pectolinarigenin), 6-OH luteolin 6-methyl ether and kempferol-6-methyl ether] were detected in the acetone exudates of the studied samples by means of thin layer chromatography. No differences in the accumulation of surface flavonoids were found among the tested leaf extracts of in vitro, ex vitro and in vivo samples. However, the extracts from the flowers were richer in surface flavonoids than extracts from the leaves. The methanol extracts of the samples from ex vitro and in vivo grown A. montana plants had significantly higher radical scavenging activity and polyphenolic content than the extracts of in vitro samples. The observed differences in the contents of these biologically active compounds were related to different growth conditions and stages of plant development. The biotechnological method of A. montana established holds promise for the future production of antioxidants.
\end{abstract}

Keywords: antioxidant, flavonoid, phenol, Arnica montana

\section{Introduction}

Arnica montana L. (Asteraceae) is a valuable perennial herb. The species contains sesquiterpene lactones (e.g. helenalin), phenolic acids (caffeic acid derivatives) and flavonoids (quercetin 3-O-glucuronic acid) with significant antiseptic, anti-inflammatory, antibacterial and antioxidant effects (WOERDENBAG et al. 1994, LYSS et al. 1997, IAUK et al.

* Corresponding author, e- mail: milena_n@bio.bas.bg

Copyright ${ }^{\circledR} 2013$ by Acta Botanica Croatica, the Faculty of Science, University of Zagreb. All rights reserved. 
2003, SANTOS et al. 2006). The plant has been used mainly as anti-inflammation drug and is applied topically for skin, bruises, rheumatic and muscle pains. The species is used as ingredient in many homeopathic remedies. Arnica montana is a rarely found in Bulgaria and has been reported to grow only on Rila mountain (ASSYOv and PETROVA 2006), however so far its distribution has not been confirmed. Therefore the development of a biotechnological method for in vitro propagation of the species and subsequently ex vitro and in vivo acclimatization is very important for its cultivation and sustainable use.

Phenolic compounds and flavonoids possess multiple biological effects including antioxidant, free radical scavenging abilities, inhibition of hydrolytic and oxidative enzymes, anti-inflammatory, anticarcinogenic, antibacterial, hypolipidemic, antimutagenic and other activities (Burda and OleszeK 2001, CAI et al. 2004, RochA-GuZMAN et al. 2007). They are also associated with the prevention and treatment of cardiovascular and cerebrovascular diseases (GAN et al. 2010). Arnica montana flavonoids are supposed to act synergistically with sesquiterpene lactones (WILLUHN 1991). They also serve as chemosystematic markers and are used to assess identity and purity of A. montana according to the European Pharmacopoeia (HÄNSEL and STICHER et al. 2007). The total polyphenol content and antioxidant activity of A. montana extracts have been reported in several publications (HAĂRMĂNESCU et al. 2008, Fraisse et al. 2011, GAWLIK-DzIKI et al. 2011, Moldovan et al. 2011). The literature survey showed that there is no information about the antioxidant activity of in vitro cultured A. montana plant material.

The purpose of this study was to evaluate the polyphenol content and antioxidant capacity of plants derived from in vitro culture and then adapted in greenhouse (ex vitro) and mountain conditions (in vivo).

\section{Material and methods}

\section{Plant material}

The origin of Arnica montana plants was Botanical Garden, Germany (AG). Six samples were analyzed: two in vitro samples: AGM (multiple plants), AGR (rooted plants); two ex vitro samples AG1: AG1_L (leaves), AG1_F (flower heads) of greenhouse plants from Sofia region $553 \mathrm{~m}$ a.s.l. and two in vivo sample AG2: AG2_L (leaves), AG2_F (flower heads) of cultivated plants from the Rhodope Mountains, Beglika.

\section{Preparation of extracts}

Acetone exudates. Air-dried (but not ground) 1g plant material was briefly (2-3 min) rinsed with acetone at room temperature to dissolve the lipophilic components accumulated on the surface. The obtained acetone filtrate was then dried using a rotary-evaporator to give a crude extract which was suspended in $\mathrm{MeOH}$ and then subjected on TLC.

Methanol extracts. Dry, ground plant material (1 g) was extracted with 80\% (3 x 30 $\mathrm{mL}$ ) methanol by classic maceration for $24 \mathrm{~h}$. After evaporation of the solvent the crude extract was subjected to subsequent analysis.

Biotechnological tools: The in vitro propagation protocol of A. montana plants consisted of four stages: 1) an initial stage - obtaining seedlings on basal MS medium (Murashige and SKOOG 1962) with $40 \mathrm{mg} \mathrm{L}^{-1}$ gibberellic acid; 2) a propagation stage - 
shoot formation on MS medium supplemented with $1 \mathrm{mg} \mathrm{L}^{-1}$ 6-benzylaminopurine and 0.1 $\mathrm{mg} \mathrm{L}^{-1}$ indole-3-acetic acid; 3 ) rooting stage - shoot rooting on half strength MS medium containing $0.5 \mathrm{mg} \mathrm{L}^{-1}$ indole-3-butyric acid; 4) ex vitro acclimatization of plants was carried out on a mix of peat, perlite and coconut fiber $(2: 1: 1 \mathrm{v} / \mathrm{v} / \mathrm{v})$ for 4 weeks. Then the plants were adapted in the experimental field in the Rhodopes Mountains at an altitude of $1500 \mathrm{~m}$ a.s.l (in vivo plants).

\section{Cultural conditions}

In vitro cultures were maintained in a growth room at temperature of $22 \pm 2{ }^{\circ} \mathrm{C}$ under a $16 \mathrm{~h}$ photoperiod with light intensity of $40 \mu \mathrm{M} \mathrm{m}^{-2} \mathrm{~s}^{-1}$ provided by cool white fluorescent tubes. The micropropagated plants were cultivated in ex vitro conditions ata temperature of $24 \pm 2{ }^{\circ} \mathrm{C}$ under a $16 \mathrm{~h}$ photoperiod with a light intensity of $50 \mu \mathrm{M} \mathrm{m}^{-2} \mathrm{~s}^{-1}$ with subsequent transfer to greenhouse. Then the plants were adapted in the experimental field in the Rhodopes Mountains at an altitude of $1500 \mathrm{~m}$ a.s.l (in vivo plants).

\section{Thin layer chromatographic analysis of flavonoid aglycones}

The acetone exudates were screened for surface flavonoids by TLC analysis. Three TLC sorbents and three mobile phases were used for the analysis of the flavonoid exudates. Toluene-dioxan-acetic acid (95:25:4, v/v/v) was applied for the development of the aglycones mixture on silica gel plates Kiselgel $60 \mathrm{~F}_{254}(10 \times 20 \mathrm{~cm}, 0.2 \mathrm{~mm}$ layer). Toluene-methylethylketone-methanol (60:25:15, v/v/v) was used for DC-Alufolien Polyamid 11 $\mathrm{F}_{254}$ plates $(10 \times 20 \mathrm{~cm}, 0.15 \mathrm{~mm}$ layer $)$. Acetic acid-water $(30: 70, \mathrm{v} / \mathrm{v})$ was used for cellulose plates DC-Alufolien Cellulose $5552(10 \times 20 \mathrm{~cm}, 0.1 \mathrm{~mm}$ layer). Chromatograms were viewed under UV light before and after spraying with »Natural product reagent $\mathrm{A} \ll$, $1 \%$ solution of diphenylboric acid 2-aminoethyl ester complex in methanol. The identification of the compounds was achieved by co-chromatography with authentic markers obtained from Prof. Eckhard Wollenweber.

Determination of total phenolic content. Total phenolic content of the methanol extracts was determined by employing the methods given in the literature involving Folin-Ciocalteu reagent and gallic acid as standard (GIORGI et al. 2009, NićIFOROVIĆ et al. 2010). Plant extracts were diluted to a concentration of $1 \mathrm{mg} \mathrm{mL}^{-1}$, and aliquots of $0.5 \mathrm{~mL}$ were mixed with $2.5 \mathrm{~mL}$ of Folin-Ciocalteu reagent (previously diluted 10-fold with distilled water) and $2 \mathrm{~mL}$ of $\mathrm{Na}_{2} \mathrm{CO}_{3}(6 \%)$. After $1 \mathrm{~h}$ at room temperature, the absorbances of the samples were measured at $765 \mathrm{~nm}$ on spectrophotometer versus blank sample. Total phenols were determined as gallic acid equivalents (mg GA per $\mathrm{g}$ of extract) by the following formula:

$$
\mathrm{C}=\mathrm{c} \times \mathrm{V} / \mathrm{m}
$$

where $\mathrm{C}$ is total content of phenolic compounds, $\mathrm{mg} \mathrm{g}^{-1}$ plant extract, in GAE; $\mathrm{c}$ is the concentration of gallic acid established from the calibration curve in $\mu \mathrm{g} \mathrm{mL}^{-1} ; \mathrm{V}$ is the volume of extract in $\mathrm{mL} ; \mathrm{m}$ is the weight of pure plant methanolic extract in grams.

Determination of total flavonoid content. Total flavonoid content was determined according to MiLIAUSKASA et al. (2004), using rutin as a reference compound. One mL of plant 
extract in methanol $\left(10 \mathrm{~g} \mathrm{~L}^{-1}\right)$ was mixed with $1 \mathrm{~mL}$ aluminium trichloride in ethanol $(20 \mathrm{~g}$ $\mathrm{L}^{-1}$ ) and diluted with ethanol to $25 \mathrm{~mL}$. The absorption at $415 \mathrm{~nm}$ was read after $40 \mathrm{~min}$ at room temperature. Blank samples were prepared from $1 \mathrm{~mL}$ plant extract and 1 drop acetic acid and diluted to $25 \mathrm{~mL}$. The absorption of rutin solutions was measured under the same conditions. Standard rutin solutions were prepared from $0.05 \mathrm{~g}$ rutin. All determinations were carried out in duplicate. The amount of flavonoids in plant extracts in rutin equivalents (RE) was calculated by the following formula:

$$
\mathrm{C}=\mathrm{Ab}_{\text {sample }} \times \mathrm{m}_{\text {control }} \times 10 / \mathrm{Ab}_{\text {control }} \times \mathrm{m}_{\text {sample }}
$$

where $\mathrm{C}$ is flavonoid content $\left(\mathrm{mg} \mathrm{g}^{-1}\right.$ plant extract) in $\mathrm{RE}$; $\mathrm{Ab}_{\text {sample }}$ is the absorption of plant extract solution; $\mathrm{Ab}_{\text {control }}$ is the absorption of standard rutin solution; $\mathrm{m}_{\text {sample }}$ is the weight of plant extract in grams; $\mathrm{m}_{\text {control }}$ is the weight of rutin in the solution in grams.

DPPH radical scavenging activity. The effect of methanolic extracts on DPPH radical was estimated according to CHOI et al. (2002) and STANOJEVIĆ et al. (2009). Different concentrations of plant extract $(10,20,50,100$ and $200 \mu \mathrm{g} / \mathrm{mL})$, in methanol were added at an equal volume $(2.5 \mathrm{~mL})$ to methanol solution of DPPH $(0.3 \mathrm{mM}, 1 \mathrm{~mL})$. After $30 \mathrm{~min}$ at room temperature, the Ab values were measured at $517 \mathrm{~nm}$ on a spectrophotometer (Jenway 6320D) and converted into the percentage antioxidant activity using the following equation:

$$
\text { DPPH antiradical scavenging capacity }(\%)=\left[1-\left(\mathrm{Ab}_{\text {sample }}-\mathrm{Ab}_{\text {blank }}\right) / \mathrm{Ab}_{\text {control }}\right] \times 100
$$

Methanol $(1.0 \mathrm{~mL})$ plus plant extract solution $(2.5 \mathrm{~mL})$ was used as a blank, while $\mathrm{DPPH}$ solution plus methanol was used as a control. The $\mathrm{IC}_{50}$ values were calculated by sigmoid non-linear regression model using plots, where the abscissa represented the concentration of tested plant extracts and the ordinate the average percent of scavenging capacity (Software Prizm 3.00). $\mathrm{IC}_{50}$ values denote the concentration of sample required to scavenge $50 \%$ of DPPH radical.

\section{Statistical analysis}

Statistical analysis was carried out using excel. All experiments were performed in triplicate. Results were presented as a value \pm standard deviation (SD). Significant levels were defined at $\mathrm{p}<0.05$ as analyzed by t-test.

\section{Results}

\section{Surface flavonoid aglycones}

Four surface flavonoid aglycones were detected in the acetone exudates of the studied samples (Fig. 1): scutellarein 6-methyl ether (hispidulin) (1), scutellarein 6,4'-dimethyl ether (pectolinarigenin) (2), 6-OH luteolin 6-methyl ether (3) and kempferol-6-methyl ether (4). Three of detected flavonoid structures belong to the flavone class of flavonoids and one belongs to the flavonol class. Thin layer chromatographic data $-\mathrm{R}_{\mathrm{F}}$ (rate of flow) and color of detected flavonoid aglycones are presented in table 1. The flavonoid aglycones (1) and (2) were the main flavonoids in all studied exudates. The flavonoid aglycones (3) and (4) 


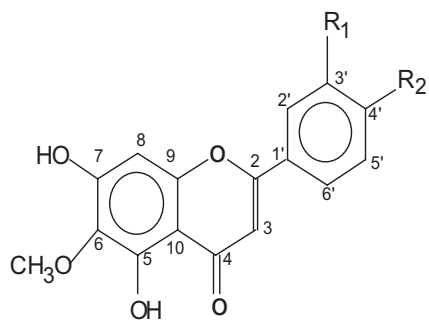

$(1,2,3)$

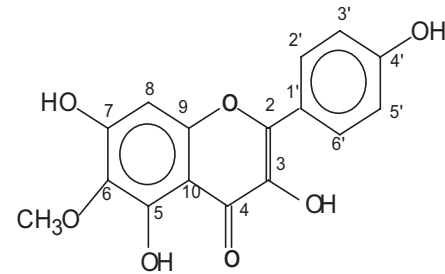

(4)

(1) $\mathrm{R}_{1}=\mathrm{H} ; \mathrm{R}_{2}=\mathrm{OH}$ scutellarein 6-methyl ether (hispidulin)

(2) $\mathrm{R}_{1}=\mathrm{H} ; \mathrm{R}_{2}=\mathrm{OCH}_{3}$ scutellarein 6,4'-dimethyl ether (pectolinarigenin)

(3) $\mathrm{R}_{1}=\mathrm{OH} ; \mathrm{R}_{2}=\mathrm{OH} 6-\mathrm{OH}$ luteolin 6-methyl ether (3)

(4) kempferol-6-methyl ether

Fig. 1. Structures of the identified flavonoid aglycones $1-4$.

Tab. 1. Thin layer chromatographic data on detected flavonoid aglycones in the studied samples of Arnica Montana

\begin{tabular}{|c|c|c|c|}
\hline \multirow{2}{*}{ Flavonoid aglycones } & \multicolumn{3}{|c|}{ Thin layer chromatographic data $-\mathrm{R}_{\mathrm{F}}$ (rate of flow) and color } \\
\hline & $\mathrm{S}_{1}$ & $\mathrm{~S}_{2}$ & $\mathrm{~S}_{3}$ \\
\hline $\begin{array}{l}\text { Scutellarein 6,4'-dimethyl } \\
\text { ether (pectolinarigenin) }\end{array}$ & $\begin{array}{l}0.52 \\
\text { (brown/ brown) }\end{array}$ & $\begin{array}{l}0.57 \\
\text { (brown/ brown) }\end{array}$ & $\begin{array}{l}0.67 \\
\text { (brown/ brown) }\end{array}$ \\
\hline $\begin{array}{l}\text { Scutellarein 6-methyl } \\
\text { ether (hispidulin) }\end{array}$ & $\begin{array}{l}0.33 \\
\text { (brown/ brown) }\end{array}$ & $\begin{array}{l}0.21 \\
\text { (brown / } \\
\text { brownish-yellow) }\end{array}$ & $\begin{array}{l}0.52 \\
\text { (brown/ brown) }\end{array}$ \\
\hline $\begin{array}{l}\text { Kempferol-3-methyl } \\
\text { ether }\end{array}$ & $\begin{array}{l}0.39 \\
\text { (brown / } \\
\text { brownish-yellow) }\end{array}$ & $\begin{array}{l}0.15 \\
\text { (brownish-yellow / } \\
\text { yellow) }\end{array}$ & $\begin{array}{l}0.28 \\
\text { (brownish-yellow / } \\
\text { yellow) }\end{array}$ \\
\hline $\begin{array}{l}\text { 6-OH luteolin } \\
\text { 6-methyl ether }\end{array}$ & $\begin{array}{l}0.16 \\
\text { (brown / orange) }\end{array}$ & $\begin{array}{l}0.06 \\
\text { (brown / yellow) }\end{array}$ & $\begin{array}{l}0.21 \\
\text { (brown / Light orange) }\end{array}$ \\
\hline
\end{tabular}

$S_{1}-$ sorbent=silicagel, eluent=toluene:dioxan:acetic acid (90:25:4); $S_{2}-$ sorbent $=$ polyamid, eluent $=$ toluene:methylethylketone:methanol (60:25:15); $S_{3}-$ sorbent - cellulose, eluent $=30 \%$ acetic acid

were detected in trace amounts in the leaf exudates while in the flower exudates they were present in high quantities. Differences among the leaf exudates of studied samples were not observed.

\section{Total phenolic content}

The results of total phenolic content determination in the methanol extracts of studied samples, evaluated using Folin - Ciocalteu method, are presented in table 2. The content of phenols in extracts of in vitro samples AGM and AGR expressed as gallic acid equivalents (GAE) was 23.65 to $24.78 \mathrm{mg} \mathrm{g}^{-1}$ of dry extract, respectively. There were no significant differences in content of total phenols $(p>0.05)$ among the methanol extracts of in vitro 
Tab. 2. Polyphenol content and free radical scavenging activity of samples of in vitro, ex vitro and in vivo grown Arnica montana plants

\begin{tabular}{llccc}
\hline Sample & Plant part & $\begin{array}{c}\text { Total phenols* } \\
\text { mg GAE/g extract }\end{array}$ & $\begin{array}{c}\text { Total flavonoids* } \\
(\mathrm{mg} \text { RE/g extract })\end{array}$ & $\begin{array}{c}\text { DPPH scavenging } \\
\text { activity } \\
\text { IC }_{50}(\mu \mathrm{g} / \mathrm{mL})\end{array}$ \\
\hline AGM in vitro & Leaves & $23.65 \pm 1.6^{\mathrm{a}}$ & $1.48 \pm 0.8^{\mathrm{d}}$ & $>200^{\mathrm{k}}$ \\
AGR in vitro & Leaves & $24.78 \pm 1.1^{\mathrm{a}}$ & $1.49 \pm 0.7^{\mathrm{d}}$ & $>200^{\mathrm{k}}$ \\
AG1_L ex vitro & Leaves & $38.13 \pm 3.5^{\mathrm{b}}$ & $4.20 \pm 1.4^{\mathrm{f}}$ & $64.01 \pm 5,51^{\mathrm{h}}$ \\
AG1_F ex vitro & Flower heads & $36.41 \pm 5.9^{\mathrm{b}}$ & $9.21 \pm 1.1^{\mathrm{e}}$ & $85.73 \pm 8,11^{\mathrm{j}}$ \\
AG2_Lin vivo & Leaves & $57.80 \pm 4.2^{\mathrm{c}}$ & $4.54 \pm 1.6^{\mathrm{f}}$ & $33.79 \pm 6,32^{\mathrm{g}}$ \\
AG2_F in vivo & Flower heads & $51.25 \pm 2.6^{\mathrm{c}}$ & $9.5 \pm 2.7^{\mathrm{e}}$ & $60.22 \pm 7,51^{\mathrm{h}}$ \\
\hline
\end{tabular}

AGM - in vitro sample multiple stage; AGR - in vitro sample, plant rooting stage; AG1_L - ex vitro grown plants, leaves, AG1_F - ex vitro grown plants, flower heads; AG2_L - in vivo grown plants, leaves; AG2_F - in vivo grown plants, flower heads; GAE- gallic acid equivalents; RE - rutin equivalents. * values represent mean $\pm \mathrm{SD}, \mathrm{n}=3$. Values with the same letter are not significantly different, $\mathrm{p} \geq$ 0.05

samples. The leaf extracts of ex vitro and in vivo (AG1 L and AG2 L) developing plants contain higher levels of phenols compared to extracts of in vitro samples, respectively 38.13 and $57.80 \mathrm{mg} \mathrm{g}^{-1}$ of dry extract. The extracts from flower heads of the same samples (AG1 F and AG2 F) contained phenols of respectively 36.41 and $51.25 \mathrm{mg} \mathrm{g}^{-1}$ of dry extract. The extracts of in vivo (AG2 L and AG2 F) samples contain higher phenols than extracts of ex vitro samples (AG1 L and AG1 F). The marked differences were statistically significant $(\mathrm{p}<$ 0.05). There were no significant differences in the phenolic content $(p>0.05)$, between the extracts of flower heads and leaves of a separate samples.

\section{Total flavonoid content}

Flavonoid contents is expressed as rutin equivalents: mg RE per g of dry extract. The amount of flavonoids was the lowest in the leaf extracts from in vitro grown plants AGM and AGR - 1.48 and $1.49 \mathrm{mg} \mathrm{g}^{-1}$ (Tab. 2). No differences in the content of total flavonoids among leaf extracts from ex vitro and in vivo grown plants (AG1 L and AG2 L) were observed -4.20 and $4.54 \mathrm{mg} \mathrm{g}^{-1}$ of dry extract, respectively. However, a significant difference $(\mathrm{p}<0.05)$ was found in the content of flavonoids between extracts of leaves and flowers of a sample. The extracts of flower heads of ex vitro and in vivo grown plants (AG1 F and AG2 F) contain flavonoids of respectively 9.21 and $9.50 \mathrm{mg} \mathrm{g}^{-1}$ of dry extract.

\section{DPPH free-radical scavenging activity}

The degree of discoloration of violet colour of DPPH., as it gets reduced, indicated the radical scavenging potential of the antioxidant. Results of the DPPH scavenging activity of studied samples, expressed as $\mathrm{IC}_{50}$ value that represent the concentration of the sample required to scavenge $50 \%$ of DPPH radicals, are given in table 2 .

It was found that the leaf extracts of ex vitro and in vivo samples had the strongest radical scavenging activity, respectively $\mathrm{IC}_{50}=64.01$ and $33.79 \mu \mathrm{g} \mathrm{mL}{ }^{-1}$. The extracts of in 
vitro samples showed low activity and their $\mathrm{IC}_{50}$ values were above $200 \mu \mathrm{g} \mathrm{mL}^{-1}$. The extracts of flower heads of ex vitro and in vivo samples showed slightly lower activity than the corresponding leaf extracts $\mathrm{IC}_{50}=85.73$ and $60.22 \mu \mathrm{g} \mathrm{mL}^{-1}$ respectively.

\section{Discussion}

The commercial importance of polyphenols has led to attempts to develop alternative systems for their production. The advantage of using the tissue and organ cultures is more stable production of secondary metabolites than cultures of undifferentiated cells, such as cells in callus or suspension culture (RAMACHANDRA RAO and RAVISHANKAR 2002). In the present study surface flavonoids, total phenols and flavonoids as well as the antioxidant potential of extracts from in vitro, ex vitro and in vivo grown plants of Arnica montana were analyzed. It was found that there was no difference in the synthesis of surface flavonoids among in vitro, ex vitro and in vivo grown plants. Differences were observed in the composition of surface flavonoids between the exudates of leaves and flower heads. The exudates of flower heads contained a high quantity of the flavonoids 6-OH luteolin 6-methyl ether and kempferol-6-methyl ether. This is in accordance with reports of other authors for differences in surface flavonoid composition in different plant organs (WILLIAMS et al. 1999).

The results of quantitative analysis showed that the total content of phenols and flavonoids in the extracts of in vitro cultures were lower than in the extracts of ex vitro and in vivo grown plants. The differences in the content of these secondary metabolites might be due to the different growth conditions and stages of plant development. The lower level of phenols in extracts of in vitro samples compared to extracts of field grown plants has been already reported (STANLY et al. 2001, RAMES et al. 2009, PARSAEIMEHR et al. 2010, SAGWAN et al. 2011, SinGH et al. 2011). RAMESH et al. (2009) explained the increased synthesis of phenols in natural conditions as a defensive reaction to environmental stress.

The higher content of total phenols in in vivo grown plants than in those from ex vitro adapted plants could be explained by the different altitudes at which they were grown, respectively Central Rhodopes - Beglica 1500 m a.s.l. and greenhouse, Sofia region $553 \mathrm{~m}$ a.s.l. The positive correlation between altitude and the content of caffeic acid derivatives in A. montana cv Arbo flower heads was reported (SPITALER et al. 2006, 2008). Higher levels of flavonoids in the extracts of flower heads of ex vitro and in vivo grown plants were observed compared to corresponding leaf extracts. This result is in agreement with other studies reporting flavonoid concentration in different plant parts (SAVICKIENE et al. 2002, TOMCZYK and Gudes 2003, KHATIwORA et al. 2010)

The extracts of ex vitro and in vivo samples had a radical scavenging activity greater than that of the extracts from in vitro samples. Higher activity of the extracts of these samples corresponds to a high content of phenols in them. A positive correlation between total phenolic contents and antioxidant activity has been reported by many authors (CAI et al. 2004, ShAn et al. 2005, Wong et al. 2006, Wu et al. 2006, MoldovAn et al. 2011, MAizurA et al. 2011). Moreover, the results presented confirm earlier observations that the antioxidant activity of extracts is correlated more strongly with the content of phenolics than that of flavonoids (MiliausKasA et al. 2004, NićIfOROVić et al. 2010, NiKOlOVA 2011). To the best of our knowledge the present study is the first report of polyphenol content and free radical scavenging activity of in vitro grown plants of Arnica montana. 
In conclusion, four surface flavonoid aglycones were identified in the acetone exudates of the studied samples of A. montana. No differences were observed in the synthesis of surface flavonoids among the extracts of in vitro, ex vitro and in vivo samples. But there was a difference between different organs - the extracts of the flower heads were richer in surface flavonoids than leaf extracts.

The antioxidant capacity and total flavonoid and phenolic content of the studied samples increased in the order in vitro, ex vitro and in vivo grown plants of $A$. montana. The extracts of flower heads were the richest in total flavonoids, but leaf extracts had the highest content of phenols and exhibited the highest free radical scavenging activity. A. montana plants obtained by in vitro technique and grown under natural conditions could be an appropriate source of antioxidants. The selection of highly productive lines as well as the optimization of cultivation environments is a prerequisite for the application of this system.

\section{Acknowledgements}

The authors are grateful for the financial support provided by the Bulgarian National Science Fund, Ministry of Education, Youth and Science (Project DTK-02/38). Also the authors thank Prof. E. Wollenweber for the kind gift of the flavonoid standards.

\section{References}

Assyov, B., Petrova, A., 2006: Conspectus of the Bulgarian vascular flora (in Bulgarian). Bulgarian Biodiversity Foundation, Sofia.

Burda, S., OleszeK, W., 2001: Antioxidant and antiradical activities of flavonoids. Journal of Agricultural and Food Chemistry 49, 2774-2779.

CAI, Y., LuO, Q., Sun, M., CoRKe, H., 2004: Antioxidant activity and phenolic compounds of 112 Chinese medicinal plants associated with anticancer. Life Sciences 74, 2157-2184.

Choi, C. W., Kim, S. C., Hwang, S. S., Choi, B. K., Ahn, H. J., Lee, M. Y., Park, S. H., Kim, S. K., 2002: Antioxidant activity and free radical scavenging capacity between Korean medicinal plants and flavonoids by assay-guided comparison. Plant Science 163, 11611168.

Gan, R. Y., Xu, X. R., Song, F. L., KuAnG, L., Li, H. B., 2010: Antioxidant activity and total phenolic content of medicinal plants associated with prevention and treatment of cardiovascular and cerebrovascular diseases. Journal of Medicinal Plants Research, 4, 24382444.

Gawlik-Dziki, U., Swieca, M., Sugier, D., Cichocka, J., 2011: Comparison of in vitro lipoxygenase, xanthine oxidase inhibitory and antioxidant activity of Arnica montana and Arnica chamissonis tinctures. Acta Scientiarum Polonorum-Hortorum Cultus 10, $15-27$.

Giorgi, A., Mingozzi, M., Madeo, M., Speranza, G., Cocucci, M., 2009: Effect of nitrogen starvation on the phenolic metabolism and antioxidant properties of yarrow (Achillea collina Becker ex Rchb.). Food Chemistry 114, 204-211.

Fraisse, D., Felgines, C., TeXier, O., Lamaison, J. L. 2011: Caffeoyl derivatives: major antioxidant compounds of some wild herbs of the Asteraceae family. Food and Nutrition Sciences 2, 181-192. 
HaĂRmĂnescu, M., Moisuc, A., RAdu, F., DrĂGAn, S., GERgen, I., 2008: Total polyphenols content determination in complex matrix of medicinal plants from Romania by NIR spectroscopy. Bulletin UASVM, Agriculture 65, 123-128.

HÄNSEl, R., Sticher, O., 2007: Pharmakogonosie - Phytopharmazie. Springer, Heidelberg.

Iauk, L., Lo, Bue, A. M., Milazzo, I., Rapisarda, A., Blandino, G., 2003: Antibacterial activity of medicinal plant extracts against periodontopathic bacteria. Phytotherapy Research 17, 599-604.

Khatiwora, E., Adsul, V. B., Kulkarni, M. M., Deshpandel, N. R., Kashalkar, R., V., 2010: Spectroscopic determination of total phenol and flavonoid contents of Ipomoea carnea. International Journal of ChemTech Research 2, 1698-1701.

Lyss, G., Schmidt, T. J., Merfort, I., PAHL, H. L., 1997: Helenalin, an anti-inflammatory sesquiterpene lactone from Arnica, selectively inhibits transcription factor NF-kappa-B. Biological Chemistry 378, 951-961.

Maizura, M., Aminah, A., Wan AidA, W. M., 2011: Total phenolic content and antioxidant activity of kesum (Polygonum minus), ginger (Zingiber officinale) and turmeric (Curcuma longa) extract. International Food Research Journal 18, 529-534.

Miliauskasa, G., Venskutonisa, P. R., van Beek, T. A., 2004: Screening of radical scavenging activity of some medicinal and aromatic plant extracts. Food Chemistry 85, 231-237.

Moldovan, L., Gaspar, A., Toma, L., Craciunescu, O., Saviuc, C., 2011: Comparison of polyphenolic content and antioxidant capacity of five Romanian traditional medicinal plants. Revista De Chimie 62, 299-303.

Murashige, T., Skoog, F., 1962: A revised medium for rapid growth and bioassays with tobacco tissue cultures. Physiologya Plantarum 15, 473-497.

Nićiforović, N., Mihailović, V., Masković, P., Solujić, S., Stojković, A., Muratspahić, D. P., 2010: Antioxidant activity of selected plant species; potential new sources of natural antioxidants. Food and Chemical Toxicology 48, 3125-30.

NiKolova, M., 2011: Screening of radical scavenging activity and polyphenol content of Bulgarian plant species. Pharmacognosy Research 3, 256-259.

RAMESh, J., Anshul, S., JAT, B. L., 2009: Analysis of antioxidant activity in extracts of Calotropis procera (Ait.) R.Br. Journal of Applied Biosciences 17, 899-903.

RAMACHANDRARAO, S., RAVISHANKAR, G. A., 2002: Plant tissue cultures; chemical factories of secondary metabolites. Biotechnology Advances 20, 101-153.

Rocha-Guzman, N. E., Herzog, A., Gonzalez-laredo, R. F., Ibarra-Perez, F. J., ZamBRANO-Galvan, G., Gallegos-Infante, J. A., 2007: Antioxidant and antimutagenic activity of phenolic compounds in three different colour groups of common bean cultivars (Phaseolus vulgaris). Food Chemistry 103, 521-527.

TOMCZYK, M., GudEJ, J., 2003: Quantitative analysis of flavonoids in the flowers and leaves of Ficaria verna Huds. Zeitschrift für Naturforschung 58c, 762-764.

Sagwan, S., RAO, D. V., Sharma, R. A., 2011: In-vitro and In-vivo antioxidant activity and total phenolic content of Pongamia pinnata (L.) Pierre: an important medicinal plant. International Journal of Biotechnology 4, 568-574. 
Santos, M. D., Almeida, M. C., Lopes, N. P., De Souza, G. E., 2006: Evaluation of the anti-inflammatory, analgesic and antipyretic activities of the natural polyphenol chlorogenic acid. Biological and Pharmaceutical Bulletin 29, 2236-2240.

Savickiene, N., Dagilyte, A., Barsteigiene, Z., KaZlauskas, S., Vaiciûniene, J., 2002: Analysis of flavonoids in the flowers and leaves of Monarda didyma L (in Lithuanian). Medicina (Kaunas) 11, 1119-22.

Singh, S., TANwer B. S., Khan, M., 2011: Iin vivo and in vitro comparative study of primary metabolites of Commiphora wightii (Arnott.) Bhandari.International Journal of Applied Biology and Pharmaceutical Technology 2, 162-166.

Shan, B., CAI, Y. Z., Sun, M., CORKe, H., 2005. Antioxidant capacity of 26 spice extracts and characterization of their phenolic constituents. Journal of the Agricultural and Food Chemistry 53, 7749-7759.

Spitaler, R. P., Schlorhaufer, D., Ellmerer, E. P., Merfort, I., Bortenschlager, S., STUPPNER, H., ZIDORN, CH., 2006: Altitudinal variation of secondary metabolite profiles in flowering heads of Arnica montana cv. ARBO. Phytochemistry 67, 409-417.

SPitAler, R., Winkler, I., Lins, S., YANAR, H., StupPer, H., Zidorn, C., 2008: Altitudinal variation of phenolic contents in flowering heads of Arnica montana cv. Arbo: a 3-year comparison. Journal of Chemical Ecology 34, 369-375.

Stanly, CH., Bhatt, A., Daffaralah, Ali, H. M., Keng, Ch. L., Lim, B. P., 2011: Evaluation of free radical scavenging activity and total phenolic content in the petiole-derived callus cultures of Zingiber zerumbet Smith. Journal of Medicinal Plants Research 5, 2210-2217.

Stanojević, L., Stanković, M., Nikolić, V., Nikolić, L., Ristić, D., ČAnadanovic-BruNET, J., TumBAS, V., 2009: Antioxidant activity and total phenolic and flavonoid contents of Hieracium pilosella L. extracts. Sensors 9, 5702-5714.

Williams, Ch. A., Harborne, J. B., Geiger, H., Robin, J., Hoult, S., 1999: The Favonoids of Tanacetum parthenium and T. vulgare and their anti-infammatory properties. Phytochemistry 51, 417-423.

Willuhn, G., 1991: Arnica montana L. portrait of a medicinal plant. Arnica montana L. Pharmazeutische Zeitung 136, 2453-2468.

Woerdenbag, H. J., Merfort, I., Passreiter, C. M., Schmidt, T. J., Willuhng, W., Pras, N., KAMPINGA, H., Konings, A., 1994: Cytotoxicity of flavonoids and sesquiterpene lactones from Arnica species against the GLC-4 and the COLO 320 cell lines. Planta Medica 60, 434-437.

Wong, C., Li, H., CHEnG, K., CHEN, F., 2006: A systematic survey of antioxidant activity of 30 Chinese medicinal plants using the ferric reducing antioxidant power assay. Food Chemistry 97, 705-711.

Wu, C. Q., Chen, F., Wang, X., Kim, H. J., He, G. Q., Haley-Zitlin, V., Huang, G., 2006: Antioxidant constituents in feverfew (Tanacetum parthenium) extract and their chromatographic quantification. Food Chemistry 96, 220-227. 
Acta Bot. Croat. 72 (1), 23-33, 2013

\title{
Amino acids through developmental stages of sunflower leaves
}

\author{
NAYAN ROY ${ }^{1}$, SUBRATA LASKAR ${ }^{2}$, ANANDAMAY BARIK $^{1 *}$ \\ ${ }^{1}$ Ecology Research Laboratory, Department of Zoology, The University of Burdwan, \\ Burdwan 713 104, West Bengal, India \\ 2 Department of Chemistry, The University of Burdwan, Burdwan 713 104, West \\ Bengal, India
}

\begin{abstract}
The PICO-TAG analysis of proteins revealed that 17 protein-bound and 18 free amino acids were present throughout the developmental stages of sunflower leaves. The total protein-bound amino acid content was much higher than total free amino acid content throughout the development of sunflower leaves. The contents of protein-bound and free amino acids as well as essential and non-essential ones displayed different patterns with leaf maturation, suggesting that total protein levels are poor predictors of the nutritive status of leaves.
\end{abstract}

Key words: amino acids, Helianthus annuus, sunflower

\section{Introduction}

Studies in plant-insect interactions have mainly concentrated on the effects of insect performance of plant secondary metabolites or nutritive compounds (SCHOONHOVEN et al. 2005). The nutritional quality of plants is generally characterized in terms of total nitrogen or protein content (RUUHOLA et al. 2003), and the growth efficiency of a variety of insects is closely related to plant nitrogen content. Further, the nutritive quality of plant tissues for insects may be affected by the amino acid composition of protein (SCHOONHOVEN et al. 2005). Low protein level in the insect diet, i.e., poor food resources from a nutritional point of view possibly may lead to ingestion of some amount of toxic secondary compounds (BROADWAY and DuFFEY 1988, HAUKIOJA et al. 1991, SLANSKY and WHEELER 1992, RUUHOLA et al. 2003), which may affect optimal insect growth, survival and fecundity. The balance of amino acids that constitute plant proteins differs from that of insects and deficiency in even one essential amino acid in a herbivore diet may cause an unbalanced nitrogen metabolism in insects (BERENBAUM 1995).

* Corresponding author, e-mail: anandamaybarik@yahoo.co.in

Copyright $^{\circledR} 2013$ by Acta Botanica Croatica, the Faculty of Science, University of Zagreb. All rights reserved. 
Diacrisia casignetum Kollar (Lepidoptera: Arctiidae) is polyphytophagous and damages numerous field crops (i.e., sunflower, jute, sesame, castor, etc.) in India and many other Asian countries (ROY and BARIK 2012 a, b). It has been a serious pest of the sunflower (Helianthus annuus L.) in India for many years (BANERJEE and HAQUE 1984). It feeds gregariously on sunflower leaves leaving the mid ribs only. Variation in performance and abundance of phytophagous insects is mainly due to variation in qualitative and quantitative amounts of amino acids among host plants, including changes in the nutritional quality of leaves within a particular host plant during its different developmental stages (SCHOONHOVEN et al. 2005). Herbivores often show a preference for young leaves within a plant because of the increasing toughness along with decreased water and protein content of mature leaves (MATTSON and SCRIBER 1987; SCHOONHOVEN et al. 2005). Further, the amino acid composition of the proteins indicates the nutritive quality of plant tissues, which may affect insect's growth and development because total protein levels are poor predictors of the nutritive status of leaves (BERENBAUM 1995). Therefore, the present investigation was undertaken to determine the qualitative and quantitative variations in free and protein-bound amino acids in sunflower (Helianthus annuus L.) leaves throughout the developmental stages of sunflower leaves, which will be used as experimental diets in further studies of the herbivorous insect, $D$. casignetum to understand the nutritional ecology of this insect pest for the purpose of developing better control strategies. There have been a number of studies on the amino acid content of sunflower leaves (CABELlo et al. 2006, DuLERMO et al. 2009, AGUERA et al. 2010); but the available data mainly focuses on metabolic changes during natural ageing in sunflower leaves (CABELLO et al. 2006), amino acid changes in sunflower cotyledon during a necrotrophic fungus (i.e., Botrytis cinera) interaction (DULERMO et al. 2009) and leaf development in sunflower plants grown with varying nitrate concentrations (AGUERA et al. 2010). But, there have been no reports on the differences in free and protein-bound amino acids throughout the developmental stages of sunflower leaves.

\section{Materials and methods}

\section{Plant material}

Fresh young (1-2 weeks old), mature (2-4 weeks old) and senescent (5-7 weeks old) sunflower cv. PAC-36 leaves were harvested randomly during January, 2011 from sunflower plants (cv. PAC-36) growing in the field near Chinsurah Rice Research Center $\left(22^{\circ}\right.$ 53' N, 88 23' E), West Bengal, India (RoY and BARIK 2012a).

\section{Total amino acid content measurement}

The variability of total amino acid content of sunflower leaves throughout the development state of sunflower leaves was estimated taking $1 \mathrm{~g}$ each of fresh young, mature and senescent leaves by the method of MoORE and STEIN (1948). Each determination was repeated three times. One gram of each kind of fresh leaf was placed separately in a hot-air oven at $50 \pm 1{ }^{\circ} \mathrm{C}$ temperature for $72 \mathrm{~h}$, materials were removed from the oven, and weighed in a digital monopan balance. One portion $(25 \mathrm{mg})$ of the oven-dried sample was taken in a covered heat-resistant porcelain crucible $(50 \mathrm{~mL})$ and placed in a muffle furnace (Sunvic, UK) for burning. Material was initially allowed to smoke slowly and to lose organic matter gradually by increasing the furnace temperature at the rate of $5^{\circ} \mathrm{C} \mathrm{min}{ }^{-1}$ to $450{ }^{\circ} \mathrm{C}$ and burnt 
to ash at $450 \pm 5^{\circ} \mathrm{C}$ for $30 \mathrm{~min}$. The resultant ash was reconstituted with distilled water, dried to a constant dry weight in the hot air oven at $100 \pm 0.5^{\circ} \mathrm{C}$ for $2 \mathrm{~h}$, and weighed in a digital monopan balance. This procedure was repeated three times for each kind of leaf tissue. The total amino acid content was presented as mean $\mu \mathrm{g} \mathrm{mg}^{-1}$ ash-free leaf tissue \pm standard error.

\section{Protein-bound amino acid measurement}

A sufficient amount of freshly collected leaves (young, mature and senescent) was rinsed with double distilled water and dried on a paper towel. One hundred $\mathrm{g}$ fresh leaf samples of each kind were dipped in $3 \mathrm{~L}$ n-hexane in a $5 \mathrm{~L}$ cotton-plugged conical flask and kept in the laboratory at room temperature for 21 days. The flask was then vigorously shaken daily for $30 \mathrm{~min}$. The leaves were removed from n-hexane and dried in air at room temperature $\left(27 \pm 1^{\circ} \mathrm{C}\right)$. The dried leaf material was extracted with phosphate buffer $(\mathrm{pH} 7)$ for $30 \mathrm{~min}$, kept for $30 \mathrm{~min}$ in a $-20^{\circ} \mathrm{C}$ freezer, and was filtered through Whatman No. 41 filter paper (Maidstone, UK). Each kind of water extract was dialyzed in deionized water and then placed in a lyophilizer. The powdered protein obtained from each kind of leaf was weighed in a digital balance $( \pm 0.01 \mathrm{mg})$. This process was repeated three times for each kind of leaf and values were expressed as mean \pm standard error. These nine powdered protein samples were used for amino acid analysis separately.

The powdered protein sample $(20 \mu \mathrm{g})$ was hydrolyzed by $6 \mathrm{~N}$ hydrochloric acid containing 5\% thioglycolic acid (MATSUBARA and SASAKI 1969). The solution was sealed in a tube under nitrogen and incubated in a hot-air oven at $110{ }^{\circ} \mathrm{C}$ for $24 \mathrm{~h}$ in the PICO.TAG work station. The hydrolyzed sample and the authentic amino acids internal standard - 'Standard $\mathrm{H}^{\prime}(0.005 \mathrm{~mL})$, were taken in respective tubes, introduced into the reaction vial and dried completely. These were then separately derivatised in a solution mixture of ethanol: triethyl amine: water: phenyl isothiocyanate (7:1:1:1 v/v) in a nitrogen atmosphere at $25^{\circ} \mathrm{C}$ for 20 min (GHOSH et al. 1997). The samples were dried and reconstituted in a diluent solution $\left(\mathrm{Na}_{2} \mathrm{HPO}_{4}, 0.071 \%\right.$ w/v in distilled water with $\mathrm{pH} 7.4 ; \mathrm{pH}$ was adjusted by $10 \% \mathrm{H}_{3} \mathrm{PO}_{4}$ containing $5 \% \mathrm{v} / \mathrm{v}$ acetonitrile). Amino acids were analyzed at $38{ }^{\circ} \mathrm{C}$ as per the PICO.TAG manual using a Pico-Tag $\mathrm{C}_{18}$ hydrophobic column $(5 \mu \mathrm{m}, 3.9 \times 150 \mathrm{~mm}$; Waters $)$ and detected at $254 \mathrm{~nm}$ (chart speed $-2 \mathrm{~cm} / \mathrm{min}$ ). Amino acids present in the unknown sample was characterized by comparing the peaks of the amino acids in the 'Standard H' (Pierce, Rockford, IL, USA), and the actual amount of each amino acid present was determined from the area under the individual curve. All solvents used were of analytical grade and purchased from E. Merck (India).

\section{Free amino acid measurement}

Freshly collected leaves of each kind (young, mature and senescent) were rinsed with double distilled water and dried by paper towel. One hundred $g$ of fresh leaf samples of each kind were dipped in $2 \mathrm{~L}$ millipore water in a $5 \mathrm{~L}$ cotton-plugged conical flask and kept at room temperature $\left(27 \pm 1{ }^{\circ} \mathrm{C}\right)$ for 20 min using a magnetic stirrer. The extract of each kind was filtered through Whatman No. 41 filter paper. The filtrate was kept for $30 \mathrm{~min}$ in a $-20{ }^{\circ} \mathrm{C}$ freezer and was again filtered through Whatman No. 41 filter paper (Maidstone, UK). The water extract from each kind of leaf was placed in lyophilizer. The powdered proteins obtained were weighed in a digital monopan balance. This procedure was repeated 
three times for each of the samples of young, mature and senescent sunflower leaf. The total free amino acid content was presented as mean \pm standard error. These powdered protein samples were used for amino acid analysis separately by the above mentioned procedure.

\section{Results}

\section{Total amino acid content}

Total amino acid content varied throughout the developmental stages of sunflower leaves. Total amino acid content was the highest in mature leaves $(3.61 \pm 0.442 \mu \mathrm{g}$ per $\mathrm{mg}$ ash-free leaf tissue) followed by young leaves ( $2.88 \pm 0.378 \mu \mathrm{g}$ per $\mathrm{mg}$ ash-free leaf tissue) and senescent leaves $(2.287 \pm 0.268 \mu \mathrm{g}$ per $\mathrm{mg}$ ash-free leaf tissue).

\section{Amino acids bound in proteins}

Amino acid bound in proteins was greatest in mature leaves $\left(0.521 \pm 0.014 \mathrm{mg} \mathrm{g}^{-1}\right.$ leaf tissue) followed by young leaves $(0.441 \pm 0.012 \mathrm{mg}$ per $\mathrm{g}$ leaf tissue) and senescent leaves $(0.383 \pm 0.015 \mathrm{mg}$ per $\mathrm{g}$ leaf tissue) (Tab. 1$)$. The PICO.TAG analysis of protein-bound amino acids demonstrated that 17 different types of amino acids were present throughout

Tab. 1. Total protein-bound and free amino acid content (mg per $\mathrm{g}$ fresh leaf tissue) throughout the developmental stages of sunflower leaves

\begin{tabular}{ccc}
\hline Leaf stages & Protein-bound amino acids & Free amino acids \\
\hline Young & $0.441 \pm 0.012$ & $0.280 \pm 0.007$ \\
Mature & $0.521 \pm 0.014$ & $0.304 \pm 0.010$ \\
Senescent & $0.383 \pm 0.015$ & $0.226 \pm 0.006$ \\
\hline
\end{tabular}

Mean \pm SE, $n=3$.

the developmental stages of sunflower leaves (Tab. 2). The quantitative analysis revealed that bound monocarboxylic amino acids, aromatic amino acids, heterocyclic amino acids and sulphur-containing amino acids were present in highest level in young leaves, whereas dicarboxylic amino acids and hydroxy amino acids were present in the largest amount in mature and senescent sunflower leaves. The total monocarboxylic amino acid content gradually decreased throughout the developmental stages of sunflower leaves (from young leaf to senescent leaf). In this group, glycine was found to be absent during the development of sunflower leaves (Tab. 2). Further, alanine and leucine were present in the highest amount in young and mature leaves, respectively, whereas isoleucine was detected in trace amounts in senescent leaves.

The two amino acids of the dicarboxylic group, aspartic acid and glutamic acid and their amides, were present in moderate amounts since they represent almost $20 \%$ of the total amino acids. Further, these two amino acids increased slightly throughout the developmental age of sunflower leaves. The amount of hydroxy amino acids increased from young leaf $(22.03 \pm 0.814 \%)$ to mature leaf $(34.02 \pm 0.756 \%)$ and then slightly decreased in senescent 
Tab. 2. Percentage of amino acids ( $\mathrm{g}$ per $16 \mathrm{~g} \mathrm{~N}^{* *}$ ) bound in proteins throughout the developmental stages of sunflower leaves

\begin{tabular}{|c|c|c|c|c|}
\hline Group & & Young & Mature & Senescent \\
\hline \multirow{6}{*}{$\begin{array}{l}\text { Monocarboxylic } \\
\text { amino acids }\end{array}$} & Alanine & $11.14 \pm 0.398$ & $5.21 \pm 0.133$ & $3.44 \pm 0.144$ \\
\hline & Glycine & - & - & - \\
\hline & Valine* & $7.03 \pm 0.300$ & $6.59 \pm 0.225$ & $8.55 \pm 0.292$ \\
\hline & Leucine* & $9.60 \pm 0.518$ & $11.11 \pm 0.543$ & $8.18 \pm 0.265$ \\
\hline & Isoleucine* & $3.07 \pm 0.132$ & $4.14 \pm 0.133$ & $0.16 \pm 0.012$ \\
\hline & Total & $30.84 \pm 0.277$ & $27.05 \pm 0.318$ & $20.33 \pm 0.159$ \\
\hline \multirow[t]{3}{*}{$\begin{array}{l}\text { Dicarboxylic } \\
\text { amino acids }\end{array}$} & $\begin{array}{l}\text { Glutamic acid } \\
+ \text { glutamine }\end{array}$ & $10.40 \pm 0.219$ & $10.69 \pm 0.318$ & $11.78 \pm 0.514$ \\
\hline & $\begin{array}{l}\text { Aspartic acid } \\
+ \text { asparagine }\end{array}$ & $9.40 \pm 0.398$ & $9.65 \pm 0.179$ & $11.14 \pm 0.416$ \\
\hline & Total & $19.80 \pm 0.618$ & $20.34 \pm 0.139$ & $22.92 \pm 0.098$ \\
\hline \multirow{3}{*}{$\begin{array}{l}\text { Hydroxy amino } \\
\text { acids }\end{array}$} & Threonine* & $7.13 \pm 0.217$ & $17.55 \pm 0.497$ & $17.48 \pm 0.364$ \\
\hline & Serine & $14.90 \pm 0.537$ & $16.47 \pm 0.259$ & $15.60 \pm 0.248$ \\
\hline & Total & $22.03 \pm 0.814$ & $34.02 \pm 0.756$ & $33.08 \pm 0.612$ \\
\hline \multirow[t]{3}{*}{ Diamino acids } & Arginine* & $3.37 \pm 0.139$ & $5.67 \pm 0.352$ & $3.66 \pm 0.214$ \\
\hline & Lysine* & $2.77 \pm 0.058$ & $3.56 \pm 0.225$ & $3.82 \pm 0.156$ \\
\hline & Total & $6.14 \pm 0.081$ & $9.23 \pm 0.577$ & $7.48 \pm 0.369$ \\
\hline \multirow{3}{*}{$\begin{array}{l}\text { Aromatic amino } \\
\text { acids }\end{array}$} & Tyrosine & $5.25 \pm 0.237$ & $5.02 \pm 0.398$ & $5.65 \pm 0.179$ \\
\hline & Phenylalanine* & $8.66 \pm 0.144$ & $0.35 \pm 0.017$ & $5.92 \pm 0.352$ \\
\hline & Total & $13.91 \pm 0.093$ & $5.37 \pm 0.381$ & $11.57 \pm 0.173$ \\
\hline \multirow{3}{*}{$\begin{array}{l}\text { Heterocyclic } \\
\text { amino acids }\end{array}$} & Histidine* & - & - & - \\
\hline & Proline & $1.29 \pm 0.092$ & - & $0.7 \pm 0.011$ \\
\hline & Total & $1.29 \pm 0.092$ & - & $0.7 \pm 0.011$ \\
\hline \multirow{3}{*}{$\begin{array}{l}\text { Sulphur containing } \\
\text { amino acids }\end{array}$} & Cysteine & $0.79 \pm 0.015$ & $0.35 \pm 0.023$ & $0.43 \pm 0.012$ \\
\hline & Methionine* & $5.20 \pm 0.012$ & $3.64 \pm 0.358$ & $3.49 \pm 0.163$ \\
\hline & Total & $5.99 \pm 0.005$ & $3.99 \pm 0.381$ & $3.92 \pm 0.176$ \\
\hline \multicolumn{2}{|l|}{ Essential } & $46.83 \pm 0.162$ & $52.61 \pm 0.109$ & $51.26 \pm 0.207$ \\
\hline \multicolumn{2}{|l|}{ Non-essential } & $53.17 \pm 0.162$ & $47.39 \pm 0.109$ & $48.74 \pm 0.207$ \\
\hline
\end{tabular}

* essential amino acid; Mean \pm SE, $n=3$.

** g per $16 \mathrm{~g} \mathrm{~N}=$ Amino acid composition data were reported as grams amino acid per $100 \mathrm{~g}$ of sample for each amino acid. The nitrogen content of the sample was used to convert amino acid per $16 \mathrm{~g}$ nitrogen and the values are expressed as g per $16 \mathrm{~g} \mathrm{~N}$. For calculation of protein content, the nitrogen content is multiplied by 6.25 , the practice originated from early research of proteins that were found to contain $16 \%$ nitrogen $(100 / 16=6.25)$. 
leaf $(33.08 \pm 0.612 \%)$. Threonine was found to be present in the highest amount in mature $(17.55 \pm 0.497 \%)$ and senescent $(17.48 \pm 0.364 \%)$ leaves, whereas serine was present in the highest amount in young leaves $(14.90 \pm 0.537 \%)$ among all the amino acids. The total content of diamino acids increased from young leaf to mature leaf and then decreased in senescent leaf, but this pattern is not followed in lysine content which increased slightly throughout the developmental stages of leaves.

Aromatic amino acids were lower in mature leaves than young and senescent leaves. Tyrosine was almost same throughout the developmental age of sunflower leaves, whereas phenylalanine drastically reduced to a trace amount from young leaf to mature leaf and then it increased almost seventeen fold in senescent leaf. In the heterocyclic amino acids group, histidine was found to be absent throughout the developmental state of leaves, whereas proline was absent in mature leaf. Among the sulphur-containing amino acids, cysteine was present in a small amount at all stages of leaf development, whereas methionine decreased from young leaf to senescent leaf.

\section{Free amino acids}

Total free amino acid content was highest in mature leaves $\left(0.304 \pm 0.010 \mathrm{mg} \mathrm{g}^{-1}\right)$ followed by young leaves $\left(0.280 \pm 0.009 \mathrm{mg} \mathrm{g}^{-1}\right)$ and senescent leaves $\left(0.226 \pm 0.006 \mathrm{mg} \mathrm{g}^{-1}\right)$ (Tab. 1). The amount of the total monocarboxylic amino acids group gradually decreased throughout the development of sunflower leaves, like bound amino acids (Tab. 3). Though, the amount of this group was higher throughout the development of sunflower leaves in comparison with bound amino acids. Unlike bound amino acids, alanine was found to be absent, and glycine was present throughout the development stages of sunflower leaves. Further, glycine also formed a large portion of amino acids in mature leaves.

The amount of aspartic acid and glutamic acid (and their amides) increased from young leaf to mature leaf stage and then a decrease was observed in senescent leaf (Tab. 3). The amount of hydroxy amino acid was lower throughout the developmental stages of sunflower leaves in comparison with bound amino acids, but serine content was high in mature and senescent leaves in comparison with bound forms. The diamino acid content was higher than the bound amino acid content in young and senescent leaves. In mature leaves a decreased free amino acid content was observed due to a drastic reduction of arginine.

Tyrosine gradually decreased throughout the developmental stages of sunflower leaves. The percentage of phenylalanine was almost doubled from young leaf to senescent leaf except in the mature leaf where a large decrease (i.e., 2.26 fold from young leaf) was noticed. Phenylalanine was very high in mature and senescent leaves in comparison with the bound amino acid form. Histidine, which formed a major portion of heterocyclic amino acids in young and senescent leaves, was absent in bound amino acids. The percentage of proline content was almost equal in young and senescent leaf, but increased or decreased almost 3.5 fold in mature leaf from that in young leaf or senescent leaf, respectively. Among the sulphur-containing amino acids, methionine followed almost the same pattern as the bound form whereas cysteine content was higher in the free amino acid form. The drastic decrease in the contents of essential free amino acids in mature leaves was due to an increase in the contents of non-essential amino acids. 
Tab. 3. Percentage of free amino acids ( $\mathrm{g}$ per $16 \mathrm{~g} \mathrm{~N}^{* *}$ ) throughout the developmental stages of sunflower leaves

\begin{tabular}{|c|c|c|c|c|}
\hline Group & & Young & Mature & Senescent \\
\hline \multirow{6}{*}{$\begin{array}{l}\text { Monocarboxylic } \\
\text { amino acids }\end{array}$} & Alanine & - & - & - \\
\hline & Glycine & $7.74 \pm 0.243$ & $20.69 \pm 0.508$ & $6.25 \pm 0.248$ \\
\hline & Valine* & $12.14 \pm 0.490$ & $6.51 \pm 0.323$ & $11.90 \pm 0.473$ \\
\hline & Leucine* & $9.48 \pm 0.363$ & $2.92 \pm 0.207$ & $4.97 \pm 0.185$ \\
\hline & Isoleucine* & $3.55 \pm 0.133$ & $2.26 \pm 0.121$ & $3.47 \pm 0.121$ \\
\hline & Total & $32.91 \pm 0.249$ & $32.38 \pm 0.502$ & $26.59 \pm 0.658$ \\
\hline \multirow[t]{3}{*}{$\begin{array}{l}\text { Dicarboxylic } \\
\text { amino acids }\end{array}$} & $\begin{array}{l}\text { Glutamic acid } \\
+ \text { glutamine }\end{array}$ & $8.82 \pm 0.341$ & $9.22 \pm 0.266$ & $4.22 \pm 0.162$ \\
\hline & $\begin{array}{l}\text { Aspartic acid } \\
+ \text { asparagine }\end{array}$ & $2.43 \pm 0.109$ & $8.34 \pm 0.213$ & $3.84 \pm 0.109$ \\
\hline & Total & $11.25 \pm 0.450$ & $17.56 \pm 0.479$ & $8.06 \pm 0.271$ \\
\hline \multirow{3}{*}{$\begin{array}{l}\text { Hydroxy amino } \\
\text { acids }\end{array}$} & Threonine* & $1.19 \pm 0.075$ & $4.33 \pm 0.167$ & $1.27 \pm 0.121$ \\
\hline & Serine & $6.29 \pm 0.265$ & $23.28 \pm 0.554$ & $19.69 \pm 0.487$ \\
\hline & Total & $7.48 \pm 0.341$ & $27.61 \pm 0.722$ & $20.96 \pm 0.609$ \\
\hline \multirow[t]{3}{*}{ Diamino acids } & Arginine* & $12.17 \pm 0.421$ & $0.94 \pm 0.012$ & $10.77 \pm 0.179$ \\
\hline & Lysine* & $1.82 \pm 0.185$ & $1.06 \pm 0.139$ & $1.00 \pm 0.040$ \\
\hline & Total & $13.99 \pm 0.236$ & $2.00 \pm 0.150$ & $11.77 \pm 0.219$ \\
\hline \multirow{3}{*}{$\begin{array}{l}\text { Aromatic amino } \\
\text { acids }\end{array}$} & Tyrosine & $9.48 \pm 0.440$ & $6.56 \pm 0.150$ & $3.19 \pm 0.092$ \\
\hline & Phenylalanine* & $6.66 \pm 0.162$ & $2.94 \pm 0.080$ & $13.83 \pm 0.306$ \\
\hline & Total & $16.14 \pm 0.375$ & $9.5 \pm 0.231$ & $17.02 \pm 0.398$ \\
\hline \multirow{3}{*}{$\begin{array}{l}\text { Heterocyclic } \\
\text { amino acids }\end{array}$} & Histidine* & $10.85 \pm 0.312$ & $0.84 \pm 0.017$ & $9.61 \pm 0.145$ \\
\hline & Proline & $1.14 \pm 0.069$ & $4.17 \pm 0.103$ & $1.23 \pm 0.069$ \\
\hline & Total & $11.99 \pm 0.381$ & $5.01 \pm 0.121$ & $10.84 \pm 0.214$ \\
\hline \multirow{3}{*}{$\begin{array}{l}\text { Sulphur containing } \\
\text { amino acids }\end{array}$} & Cysteine & $1.66 \pm 0.133$ & $2.03 \pm 0.138$ & $1.41 \pm 0.133$ \\
\hline & Methionine* & $4.58 \pm 0.248$ & $3.91 \pm 0.133$ & $3.35 \pm 0.132$ \\
\hline & Total & $6.24 \pm 0.381$ & $5.94 \pm 0.272$ & $4.76 \pm 0.266$ \\
\hline \multicolumn{2}{|l|}{ Essential } & $62.44 \pm 0.092$ & $25.71 \pm 0.519$ & $60.17 \pm 0.216$ \\
\hline \multicolumn{2}{|l|}{ Non-essential } & $37.56 \pm 0.092$ & $74.29 \pm 0.519$ & $39.83 \pm 0.216$ \\
\hline
\end{tabular}

* essential amino acid; Mean \pm SE, $n=3$.

** g per $16 \mathrm{~g} \mathrm{~N}=$ Amino acid composition data were reported as grams amino acid per $100 \mathrm{~g}$ of sample for each amino acid. The nitrogen content of the sample was used to convert amino acid per $16 \mathrm{~g}$ nitrogen and the values are expressed as g per $16 \mathrm{~g} \mathrm{~N}$. For calculation of protein content, the nitrogen content is multiplied by 6.25 , the practice originated from early research of proteins that were found to contain $16 \%$ nitrogen $(100 / 16=6.25)$. 


\section{Discussion}

The overall total amino acid concentrations in plants vary extremely, depending, however, on environmental conditions (SHobana et al. 2010). Amino acid is an important factor affecting the feeding behaviour of herbivorous insects. The total content of protein-bound amino acids was much higher than that of total free amino acids throughout the developmental stages of sunflower leaves, indicating that the role of protein-bound amino acids is probably more important than that of free amino acids (RuUHOLA et al. 2003). The critical importance of amino acid composition of diet to the growth and reproduction of insects is well documented in the literature (HoriE and Watanable 1983, NATION 2001). While considering variation in amino acid composition, it is important to distinguish among the developmental stages of plant leaves (KARLEY et al. 2002). This study demonstrated that changes in the contents of both free and protein-bound amino acids varied considerably throughout the development of sunflower leaves. The protein-bound amino acid content, i.e., dicarboxylic amino acids and hydroxy amino acids, is higher than free amino acid content throughout the developmental stages of sunflower leaves, whereas monocarboxylic amino acids, aromatic amino acids, heterocyclic amino acids and sulphur containing amino acids are higher in free amino acids, indicating that the roles of free and protein-bound amino acids are both important in the nutrition of herbivores. A decrease in the contents of monocarboxylic protein-bound or free amino acids occurred in senescing leaves which indicate the breakdown of cellular proteins and withdrawal of amino acids (RuUHola et al. 2003). Glycine was detected in large quantities in free amino acid forms in mature leaves, being the most abundant amino acid in this group. This amino acid, which is involved in many metabolic processes in the cell, apart from being a component in many proteins, was absent in bound forms. The relative levels of the two nitrogen-rich essential protein-bound amino acids, diamino acids, lysine and arginine, increased from young leaf to mature leaf and then decreased in senescent leaf. This decrease indicates the reduction of nutritive quality in senescent leaves (WEIBuLL et al. 1990), since these two amino acids are target sites for proteolysis by trypsin which is a common protease of insect gut (BROADWAY and DUFFEY 1988). The high level of free amino acids in young and mature leaves, especially of free glutamic acid (and its amides), reflect the active metabolism of growing tissues (WeIBULL 1987). Interestingly, the relative content of free essential amino acids decreased at the expense of non-essential amino acids from young leaf to mature leaf in sunflower plants, suggesting that the quality of the amino acid pool actually decreased. Though the relative content of free essential amino acids increased again in senescent leaves, which is due to the higher content of histidine, arginine, valine and phenylalanine. Serine in free amino acid forms was found to be most active amino acid to promote senescence of leaves, while cysteine and phenylalanine had similar but less effect (MARTin and THIMANN 1972). Senescent sunflower leaves also demonstrated a higher percentage of serine and phenylalanine than young leaves in free amino acid forms. Free aromatic amino acids are used for the synthesis of phenolic compounds and lignin (STRACK 1997). Further, phenylalanine is suggested to be a limiting factor for both the biosynthesis of phenolics and plant growth (JONES and HARTLEY 1999). The absolute content of free phenylalanine decreased 2.26 fold from young leaf to mature leaf and then increased almost five fold in senescent leaf. This suggests that phenylalanine is most active in senescent leaves and herbivorous insects do not prefer this kind of leaf. 
The process leading to developmental changes in amino acid composition might be due to developmental regulation of transporter expression from phloem loading of amino acids in leaf vascular tissue (FISCHER et al. 1995, KARLEY et al. 2002). However, there are other processes, i.e., metabolism, unloading and xylem-phloem transfer pathway which might be responsible for developmental changes of amino acid composition during leaf ageing (RENTSCH and Frommer 1996, HiRner et al. 1998, RuUHOLA et al. 2003). In the literature, clear information is available that the amino acid composition changes throughout the development of plant leaves (KARLEY et al. 2002, AMIARD et al. 2004). The reasons for this variation are probably related to fundamental aspects of plant physiology, i.e., the changes reflect the role of amino acid in both the form of nitrogen transported and the portioning of nitrogen during development (KARLEY et al. 2002).

The value of leaves for its insect pests is known to decline rapidly with leaf maturation due to decrease in water and protein content as well as increased toughness of leaves (HAUKioja et al. 2002). But changes in the profiles of the protein-bound and free amino acids may further change the nutritive value of leaves because the dietary value of proteins may be inferior due to the absence of appropriate levels of needed amino acids (BRODBECK and Strong 1987, SCHOONHOVEN et al. 2005). In conclusion, the amino acid composition of sunflower leaves in free and bound forms displayed different patterns throughout the developmental stages of sunflower leaves, which may provide useful information to clarify the quality of sunflower leaves as total protein levels are poor predictors for the nutrition for D. casignetum (RuUhola et al. 2003, Schoonhoven et al. 2005). It will be interesting to follow the behavior of the herbivorous insect $D$. casignetum when feeding on the three stages of leaves with different quantities of amino acids in free and bound forms.

\section{Acknowledgement}

This study was supported financially by the University Grants Commission, New Delhi, India through a Minor Research Project (No. F. NO. 37/615/2009).

\section{References}

Aguera, E., Cabello, P., De la HabA, P., 2010: Induction of leaf senescence by low nitrogen nutrition in sunflower (Helianthus annuus) plants. Physiologia Plantarum 138, 256-267.

Amiard, V., Morvan-Bertrand, A., Cliquet, J. B., Billard, J. P., Huault, C., Sandstrom, J. P., PRUD'Homme, M. P., 2004: Carbohydrates and amino acid composition in phloem sap of Lolium perenne L. before and after defoliation. Canadian Journal of Botany 82, 1594-1601.

BanerJee, T. C., Haque, N., 1984: Defoliation and yield loss in sunflower caused by caterpillars of Diacrisia casignetum Kollar (Lepidoptera: Arctiidae). Indian Journal of Agricultural Science 54, 137-141.

BERENBAUM, M. R., 1995: Turnabout is fair play: secondary roles for primary compounds. Journal of Chemical Ecology 21, 925-940. 
Broadway, R. M., DufFey, S. S., 1988: The effect of plant protein quality on insect digestive physiology and the toxicity of plant proteinase inhibitors. Journal of Insect Physiology 34, 1111-1117.

BrodBeck, B., Strong, D., 1987: Amino acid nutrition in herbivorous insects and stress to host plants. In: BARbosA, P., Schultz, J. C., (eds.), Insect outbreaks, 347-364. Academic Press, London.

Cabello, P., Aguera, E., Haba, P. D. L., 2006: Metabolic changes during natural ageing in sunflower (Helianthus annuus) leaves: expression and activity of glutamine synthetase isoforms are regulated differently during senescence. Physiologia Plantarum 128, 175185.

Dulermo, T., Bligny, R., Gout, E., Cotton, P., 2009: Amino acid changes during sunflower infection by necrotrophic fungus B. cinerea. Plant Signaling and Behavior 4, 859-861.

Fischer, W. N., Kwart, M., Hummel, S., Frommer, W. B., 1995: Substrate specificity and expression profile of amino acid transporters (AAPs) in Arabidopsis. Journal of Biological Chemistry 270, 16315-16320.

Ghosh, A. K., Naskar, A. K., Sengupta, S., 1997: Characterization of a xylanolytic amyloglucosidase of Termitomyces clypeatus. Biochimica et Biophysica Acta 1339, 289-296.

Horie, Y., Watanable, K., 1983: Effect of various kinds of dietary protein and supplementation with limiting amino acids on growth, haemolymph components and uric acid extraction in silk worm, Bombyx mori. Journal of Insect Physiology 19, 187-199.

Haukioja, E., Ruohomaki, K., Suomela, J., Vuorisalo, T., 1991: Nutritional quality as a defense against herbivores. Forest Ecology and Management 39, 237-245.

HAukioja, E., Ossipov, V., LEMPA, K. 2002: Leaf maturation vs. phenolics as modifiers of insect consumption and growth. Entomologia Experimentalis et Applicata 104, 125136.

Hirner, B., Fischer, W. N., Rensch, D., Kwart, M., Frommer, W. B., 1998: Developmental control of $\mathrm{H}^{1}$ /amino acid permease gene expression during seed development of Arabidopsis. The Plant Journal 14, 535-544.

Jones, C. G., HARTLEY, S. E., 1999: A protein competition model of phenolic competition. Oikos 86, 27-44.

Karley, A. J., Douglas, A. E., Parker, W. E., 2002: Amino acid composition and nutritional quality of potato leaf phloem sap for aphids. Journal of Experimental Botany 205, 3009-3018.

Martin, C., Thimann, K. V., 1972: Role of protein synthesis in the senescent leaves II. The influence of amino acids in senescence. Plant Physiology 50, 432-437.

Matsubara, H., Sasaki, R. M., 1969: High recovery of tryptophan from acid hydrolysis of proteins. Biochemical and Biophysical Research Communication 35, 175-181.

MatTson, W. J., Scriber, J. M., 1987: Nutritional ecology of insect folivores of woody plants: nitrogen, water, fiber, and mineral conditions. In: SLANSKY, F., RodRIQUEZ, J. G. (eds.), Nutritional ecology of insects, mites, spiders and related invertebrates, 105-146. John Wiley and Sons, New York. 
Moore, R. A., SteIn, W. H., 1948: Photometric ninhydrin method for use in the chromatography of amino acids. Journal of Biological Chemistry 176, 367-388.

NAtion, J. P., 2001: Insect physiology and biochemistry. CRC Press, Boca Raton.

RENTSCH, D., Frommer, W. B., 1996: Molecular approaches towards an understanding of loading and unloading of assimilates in higher plants. Journal of Experimental Botany 47, 1199-1204.

Roy, N., BARIK, A., 2012 a. The impact of variation in foliar constituents of sunflower on development and reproduction of Diacrisia casignetum Kollar (Lepidoptera: Arctiidae). Psyche 2012, Article ID 812091, 9 pages.

RoY, N., BARIK, A., 2012 b. Influence of four host plants on feeding, growth and reproduction of Diacrisia casignetum (Lepidoptera: Arctiidae). Entomological Science DOI. $1111 / \mathrm{j} .1479-8298.2012 .000546 . x$

Ruuhola, T., Ossipov, V., Lempa, K., Haukioja, E., 2003: Amino acids during development of mountain birch leaves. Chemoecology 13, 95-101.

Schoonhoven, L. M., van Loon, J. J. A., Dicke, M., 2005: Insect-Plant biology. Oxford University Press, Oxford.

Shobana, K., Murugan, K., NAResh Kumar, A., 2010: Influence of host plants on feeding, growth and reproduction of Papilio polytes (The common mormon). Journal of Insect Physiology 56, 1065-1070.

SLANSKY, F., WheELER, G. S., 1992: Caterpillars' compensatory feeding response to diluted nutrients leads to toxic allelochemical dose. Entomologia Experimentalis et Applicata $65,171-186$.

Strack, D., 1997: Phenolic metabolism. In: Dey, P. M., Harborne, J. B. (Eds.), Plant Biochemistry 387-416. Academic Press, GB-London.

WeIBULL, J., 1987: Seasonal changes in the free amino acids of oat and barley phloem sap in relation to plant growth stage and growth of Rhopalosiphum padi. Annals of Applied Biology 111, 729-736.

WeIBUll, J., RENQUiST, F., BRISHAMmAR, S., 1990: Free amino acid composition of leaf exudates and phloem sap. Plant Physiology 92, 222-226. 


\title{
Pseudo-nitzschia Peragallo (Bacillariophyceae) diversity and domoic acid accumulation in tuberculate cockles and sweet clams in M'diq Bay, Morocco
}

\author{
BenlahCEn Rijal Leblad ${ }^{* 1,2}$, Nina Lundholm ${ }^{4}$, Didier GouX ${ }^{5}$, \\ Benoît Veron ${ }^{3}$, Regia Sagou ${ }^{6}$, Hamid Taleb $^{6}$, Hassan NhHala ${ }^{1}$, \\ HASSAN ER-RAIOUI ${ }^{2}$ \\ ${ }^{1}$ Laboratoire de Phytoplancton, Institut National de Recherche Halieutique, \\ 90000 Tanger, Morocco \\ ${ }^{2}$ Faculté des Sciences et Techniques, Université Abdelmalek Essadi, Tanger, Morocco \\ ${ }^{3}$ UMR 100 PE2M, Université de Caen Basse-Normandie, 14032 Caen, France \\ ${ }^{4}$ The Natural History Museum of Denmark; Sølvgade 83S; DK-1307 Copenhagen, \\ Denmark \\ ${ }^{5}$ CMABio, Université de Caen Basse-Normandie, 14032 Caen, France \\ ${ }^{6}$ Laboratoire des Biotoxines, Institut National de Recherche Halieutique, Casablanca, \\ Morocco
}

\begin{abstract}
The diversity of Pseudo-nitzschia (Bacillariophyceae) and accumulation of the neurotoxin domoic acid (DA) in two types of shellfish; tuberculate cockles (Acanthocardia tuberculata) and sweet clams (Challista chione) was explored in M'diq Bay, Morocco during 2007. The highest abundances of Pseudo-nitzschia were found during the period from March to October, with peaks occurring in May and September. Toxin analysis showed an accumulation of domoic acid in shellfish sampled during spring and autumn. The maximum toxin concentration was $4.9 \mu \mathrm{g} \mathrm{DA} \mathrm{g}^{-1}$ of the whole tissue recorded in sweet clam during spring. Using transmission electron microscopy, thirteen Pseudo-nitzschia species were identified, eight of which are known as producers of domoic acid: $P$. multistriata, $P$. cuspidata, $P$. galaxiae, $P$. multiseries, $P$. pseudodelicatissima, $P$. pungens var aveirensis, $P$. calliantha and $P$. fraudulenta. The five non- toxic species observed were $P$. subpacifica, $P$. arenysensis, $P$. dolorosa, $P$. subfraudulenta, and $P$. cf. caciantha.
\end{abstract}

Key words: Diatoms, domoic acid, phytoplankton, Pseudo-nitzschia, shellfish, Morocco

* Corresponding author, e-mail: benlahcenr@yahoo.fr

Copyright ${ }^{\circledR} 2013$ by Acta Botanica Croatica, the Faculty of Science, University of Zagreb. All rights reserved. 


\section{Introduction}

The planktonic diatom genus Pseudo-nitzschia presently comprises 37 species ( $>20 \mu \mathrm{m}$ long), several of which have a wide biogeographical distribution (HASLE 2002). Fourteen species are known to produce domoic acid (DA), a toxin that may accumulate e.g. in shellfish, and cause amnesic shellfish poisoning (ASP) in humans eating contaminated shellfish. Human intoxication with DA gives an array of gastro-intestinal and neurological symptoms such as vomiting, diarrhoea, mental confusion, memory loss (amnesia), disorientation and coma (WRIGHT et al. 1989). The first correlation between Pseudo-nitzschia bloom and DA contained in shellfish was confirmed in Prince Edward Island, Canada (BATES et al. 1989), where $P$. multiseries abundance exceeded $15 \times 10^{6}$ cells L ${ }^{-1}$ and mussels were contaminated by $790 \mu \mathrm{g}$ of DA g ${ }^{-1}$ of shellfish meat. On the other hand, AMzIL et al. (2001) first reported DA in relation to Pseudo-nitzschia blooms on the French Mediterranean coast. Subsequently, other studies have reported detection of DA in Italy (SARNO and DAHLMANN (2000)), Greece (KANIOU- GRIGORIADOU et al. 2005, MoschANDREOU et al. 2010), Tunisia (INÈs et al. 2006) and Croatia (UJEVIĆ et al. 2010).

Massuti and Margalef (1950) and MARgalef (1969) have previously described Nitzschia delicatissima, N. pungens, and N. seriata in the Mediterranean coasts. In the last decade, several studies were conducted on the systematics of Pseudo-nitzschia, and a number of species have been identified. Species identified in Spain are $P$. brasiliana, $P$. calliantha, $P$. delicatissima, $P$. fraudulenta, $P$. multistriata, $P$. pungens, $P$. galaxiae, $P$. cacciantha, $P$. mannii, $P$. arenysensis (QUIJANO-SCHEGGIA et al. 2008, 2010) and $P$. australis (ZAPATA et al. 2011). In Italy, P. calliantha and P. delicatissima (CAROPPO et al. 2005, ZINGONE et al. 2006), P. galaxiae, P. multistriata (SARNO and DAHLMANN 2000), ORSINI et al. 2002, CERINo et al. 2005, ZINGONE et al. 2006), P. fraudulenta (ZINGONE et al. 2006) were identified. Pseudo-nitzschia calliantha (SPATHARIs et al. 2007) was identified in Greece. In the southern Black Sea (BARGU et al. 2002) and in the eastern Adriatic Sea, P. calliantha, P. fraudulenta, P. pungens, P. pseudodelicatissima, P. manii (LJUBEŠIĆ et al. 2011, MARIĆ et al. 2011) were identified. The Maghreb coasts were also investigated and some species of Pseudo-nitzschia were identified such as $P$. calliantha in Tunisia (INÈs et al. 2006) and $P$. calliantha in Algeria (ILloul et al. 2008). In Morocco, only one study dealing with Pseudo-nitzschia systematics was done, by AKALlal et al. (2002) in the Atlantic coast; seven species was identified: P. fraudulenta, $P$. multiseries, $P$. multistriata, $P$. pungens var. cingulata, . subpacifica, $P$. delicatissima and P. pseudodelicatissima.

In Morocco, PSP (paralytic shellfish poisoning) intoxication by mussels was first reported in November 1971 and October 1975 (ESSAID 1977). Subsequently, several intoxications by PSP toxins were recorded: in October 1982 with two deaths (BOURHILI 1984), in November 1994 with high number of incidences of human intoxication and four deaths (TALEB et al. 2001). The first human intoxication with domoic acid after ingestion of infected mussels probably dates back to 1978 in Al-Hoceima (Mediterranean coast), where patients who had eaten mussels (Mytilus galloprovincialis) suffered from loss of memory and disorientation. These symptoms are characteristic of DA effects on human consumers; and of other shellfish poisonings, none results in amnesiac states.

Pseudo-nitzschia blooms have frequently been observed off the western Mediterranean coast of Morocco since 2002. . Due to previous ASP episodes in and outside Morocco, it was judged important to explore Pseudo-nitzschia diversity in local areas such as M'diq bay, which is subjected to commercial shellfish exploitation and to gather knowledge on 
species dynamics in order to highlight their effect on shellfish continuation, mainly tuberculate cockles and sweet clams.

In this regard, the present study was undertaken in M'diq Bay from January to December 2007, aiming at determining the biodiversity of Pseudo-nitzschia. This study deals with their seasonal diversity follow-up and abundance and identification of putative DA producers.

\section{Material and methods}

\section{Location stations}

Sampling was performed in M'diq Bay, which is located in the west Mediterranean coast of Morocco, adjacent to the Gibraltar Strait (3543’ $\left.425 \mathrm{~N}-05^{\circ} 19^{\prime} 841 \mathrm{~W}\right)$. This sampling point is 7-10 m deep (Fig. 1). Continental inputs reach $\mathbf{M}^{\prime}$ diq Bay through one temporal and torrential stream. This bay features important socio-economic activities, particularly tourism and fishing. Among the latter, shellfish catching is important (559 tons year $\left.{ }^{-1}\right)$.

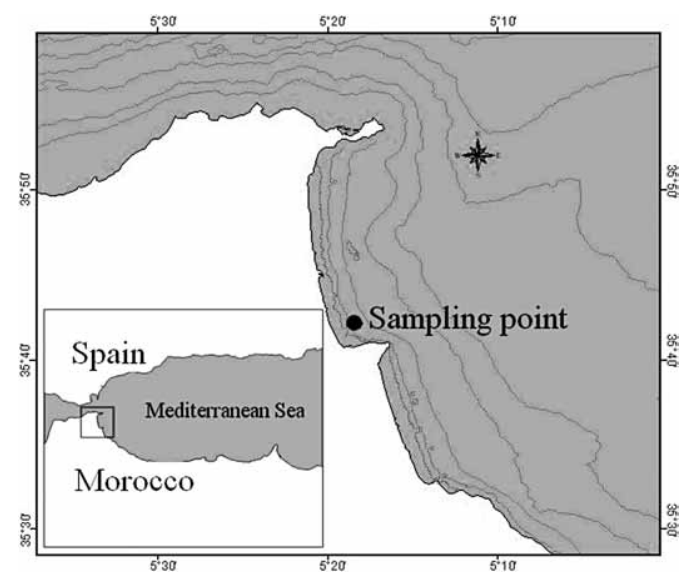

Fig. 1. Location of the sampling site in M'diq Bay (Morocco).

\section{Seawater sampling}

Seawater samples were taken on a weekly frequency basis; this was to allow a weekly estimation of Pseudo-nitzschia abundance. Seawater samples were taken using Nansen bottles at depths of $0.5 \mathrm{~m}$. Monthly samplings of seawater were also carried out using a plankton net with a $20 \mu \mathrm{m}$ mesh for Pseudo-nitzschia species identification purpose. These samples were fixed with an appropriate solution (acetic Lugol) and kept in conditions of darkness.

\section{Phytoplankton analysis}

Pseudo-nitzschia abundance was evaluated by counting using the inverteded microscope (UTERMÖHL 1958). For electron microscope analysis, about 100 specimens were examined for each sample in order to identify its species and determine its composition. 
For ultra-structural examination of the frustules, the cells were rinsed by chemical oxidation (LUNDHOLM et al. 2002); ten $\mathrm{mL}$ of each sample was transferred into $50 \mathrm{~mL}$ conical tubes. $\mathrm{CaCO}_{3}$ was removed by adding $1 \mathrm{~mL} 10 \% \mathrm{HCl}$ and overnight oxidation took place after addition of $2 \mathrm{~mL} 30 \% \mathrm{H}_{2} \mathrm{SO}_{4}$ and $10 \mathrm{~mL}$ saturated aqueous solution of $\mathrm{KMnO}_{4}$, with periodic agitation. Samples were cleared by the addition of $10 \mathrm{~mL}$ of saturated oxalic acid and rinsed with distilled water and centrifuged (3-4 times). After removal of the supernatant, $20 \mu \mathrm{L}$ of the obtained material was placed on a Millipore disc and left to dry. Examination of the grids was done by transmission electron microscope (TEM) using a Jeol/ JEM-1011.

\section{Domoic acid analysis}

Concentrations of DA were determined by HPLC (Shimadzu 10vp type). This apparatus is composed of a SCL-10vp Controller, a LC-10ADvp Quaternary Pomp, a CTO-10vp Colonne Four, a SIL-10ADvp Autosampler, a SPD-M10Avp Photodiode Array Detector, a Vydac C18 column $(250 \times 4.6 \mathrm{~mm}$, with $5 \mu \mathrm{m})$ and the Guard Cartridge (Vydac C18, $5 \mu \mathrm{m}$ ).

DA was assessed in periods of high Pseudo-nitzschia abundance. It is measured in the whole meat of cockles and sweet clams according to the QuILLIAM et al. (1995) protocol. Threefold analysis was performed using about $100 \mathrm{~g}$ of shellfish meat (ten to fifteen individuals are required to have such an amount of meat). After being shredded and homogenated, four $\mathrm{g}$ of meat were added to $16 \mathrm{~mL}$ of solvent extraction (methanol-water, 1:1) and then homogenized (Ultra-Turrax for 3 minutes at about 10,000 rpm). The homogenate was centrifuged at least at 4,000 rpm for $10 \mathrm{~min}$ to obtain supernatant. The later was analyzed using the following chromatographic conditions: mobile phase flow rate of $1 \mathrm{~mL} \mathrm{~min}^{-1}$, detector wave length of $242 \mathrm{~nm}$, injection volume of $20 \mu \mathrm{L}$ and an oven temperature for the column of $40{ }^{\circ} \mathrm{C}$. The determination of DA content in samples was done with a detection limit of 0.3 $\mu \mathrm{g} \mathrm{g}^{-1}$.

\section{Results}

\section{Domoic acid and Pseudo-nitzschia abundance}

During the sampling period (January to December 2007), Pseudo-nitzschia in M'diq Bay was present continuously in low abundance and higher abundance (ca. 10-20 cells $\mathrm{mL}^{-1}$ ) were observed from March to November (Fig. 2). Five proliferation periods ( $>30$ cells $\mathrm{mL}^{-1}$ ) were recorded during this period, with two major peaks ( 88 cells $\mathrm{mL}^{-1}$ and 157 cells $\mathrm{mL}^{-1}$ ) occurring in May and in the end of September, respectively (Fig. 2).

HPLC Analysis showed the presence of DA on five occasions (Tab. 1, Fig. 2). The highest DA levels were recorded during spring. The highest DA concentration found was $4.9 \mu \mathrm{g}$ $\mathrm{DA} \mathrm{g}^{-1}$ recorded in sweet clam in May 2007. This study reports for the first time the presence of DA in shellfish in the Mediterranean coast of Morocco. However, DA concentration never exceeded the normative threshold of $20 \mu \mathrm{g} \mathrm{AD} \mathrm{g}^{-1}$ of shellfish meat (Tab. 1).

\section{Pseudo-nitzschia diversity}

Using scanning transmission electron microscopy, thirteen species were identified as toxic (Tab. 2, Fig. 3): Pseudo-nitzschia cuspidata (Hasle), P. fraudulenta (Cleve), P. 


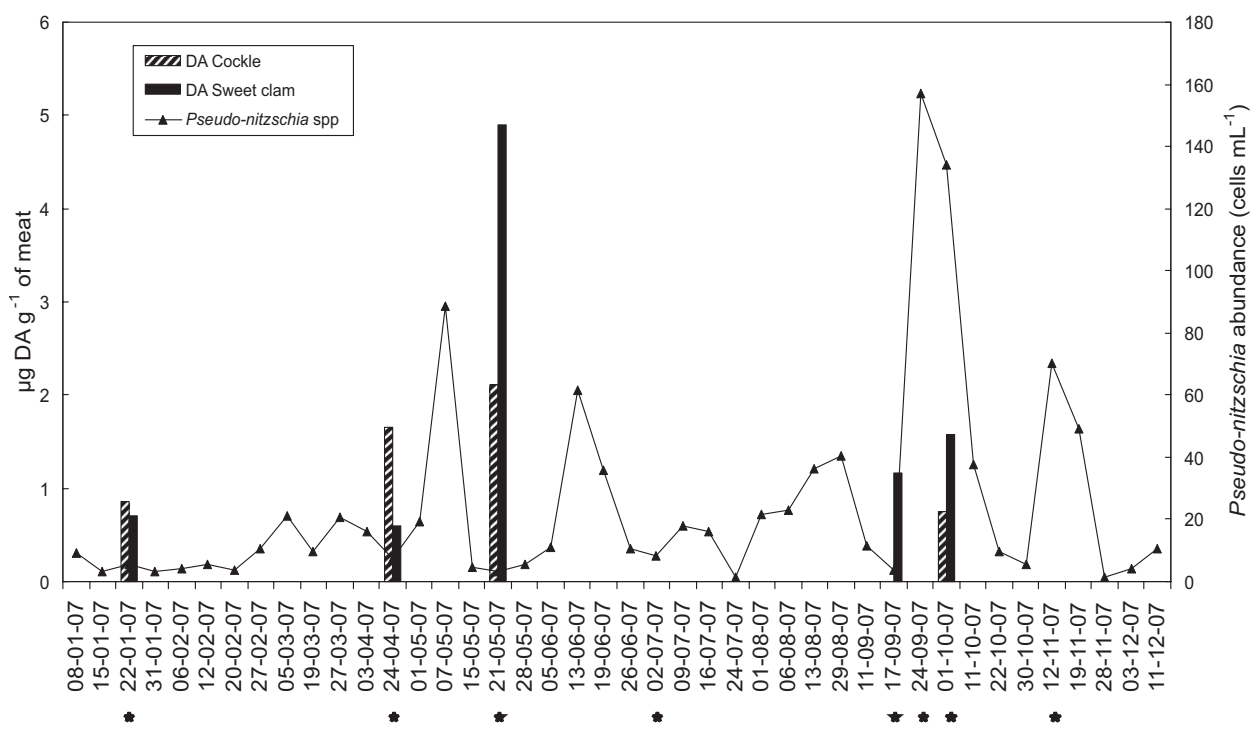

Fig. 2. Abundance of Pseudo-nitzschia and domoic acid (DA) concentrations in shellfish from M'diq Bay during 2007. $\star$ Sampling for domoic acid determination

Tab. 1. Domoic acid concentration ( $\mu \mathrm{g} \mathrm{DA} \mathrm{g}^{-1}$ of meat) in shellfish Acanthocardia tuberculata (tuberculate cockle) and Callista chione (sweet clam). ND = not detected.

\begin{tabular}{ccc}
\hline Date & $\begin{array}{c}\mu \mathrm{g} \mathrm{DA} \mathrm{g}^{-1} \text { of meat } \\
\text { (Acanthocardia tuberculata) }\end{array}$ & $\begin{array}{c}\mu \mathrm{g} \mathrm{DA} \mathrm{g}^{-1} \text { of meat } \\
(\text { Callista chione })\end{array}$ \\
\hline $2007-01-22$ & $0.85( \pm 0.10)$ & $0.71( \pm 0.80)$ \\
$2007-04-24$ & $1.66( \pm 0.19)$ & $0.59( \pm 0.7)$ \\
$2007-05-21$ & $2.11( \pm 0.25)$ & $4.90( \pm 0.58)$ \\
$2007-07-02$ & $\mathrm{ND}$ & $\mathrm{ND}$ \\
$2007-09-17$ & $\mathrm{ND}$ & $1.16( \pm 0.13)$ \\
$2007-09-24$ & $\mathrm{ND}$ & $\mathrm{ND}$ \\
$2007-10-01$ & $0.75( \pm 0.09)$ & $1.57( \pm 0.18)$ \\
$2007-11-12$ & $\mathrm{ND}$ & $\mathrm{ND}$ \\
\hline
\end{tabular}

multistriata (Takano), P. pseudodelicatissima (Hasle), P. galaxiae (Lundholm et Moestrup), $P$. multiseries (Hasle), P. calliantha (Lundholm, Moestrup et Hasle) and $P$. pungens var. aveirensis (Lundholm, Churro, Carreira et Calado). The other five non-toxic species are $P$. dolorosa (Lundholm et Moestrup), P. arenysensis (Quijano-Scheggia, Garcés, Lundholm), $P$. subpacifica (Hasle), P. subfraudulenta (Hasle), and P. cf. caciantha (Lundholm, Moestrup et Hasle).

The composition of Pseudo-nitzschia species varied greatly during the year (Fig. 4). Some species were found during a long period of the year while others appeared in specific short periods. $P$. cuspidata, $P$. fraudulenta, $P$. subpacifica and $P$. arenysensis / P. delicatissima were the most frequently recorded species. The spring and autumn periods are the 
Rujal Leblad B., Lundholm N., Goux D., Veron B., Sagou R., et al.

Tab. 2. Morphometric summary of Pseudo-nitzschia species in M'diq Bay.

\begin{tabular}{|c|c|c|c|c|c|c|c|c|}
\hline Species name & $\begin{array}{l}\text { Valve } \\
\text { shape }\end{array}$ & $\begin{array}{c}\text { Fibulae } \\
\text { in } 10 \mu \mathrm{m}\end{array}$ & $\begin{array}{l}\text { Striae in } \\
10 \mu \mathrm{m}\end{array}$ & $\begin{array}{l}\text { Row of } \\
\text { poroids }\end{array}$ & $\begin{array}{l}\text { Poroids } \\
\text { in } 1 \mu \mathrm{m}\end{array}$ & $\begin{array}{c}\text { Centrale } \\
\text { nodule }\end{array}$ & $\begin{array}{l}\text { Length } \\
(\mu \mathrm{m})\end{array}$ & $\begin{array}{l}\text { Width } \\
(\mu \mathrm{m})\end{array}$ \\
\hline P. cuspidata & lanceolate & $20-24$ & $34-41$ & 1 & $5-6$ & + & $58.5-65.3$ & $1.6-2.3$ \\
\hline P. subpacifuca & linear & $17-20$ & $28-32$ & 2(3) & $9-10$ & + & $45.2-60.1$ & $4.9-6.1$ \\
\hline $\begin{array}{l}\text { P. arenysensis/ } \\
\text { P. delicatissima }\end{array}$ & lanceolate & $20-24$ & $36-38$ & 2 & $9-12$ & + & $39.5-45.1$ & $1.8-2.1$ \\
\hline P. fraudulenta & linear & $21-24$ & $21-24$ & 2(3) & $6-7$ & + & $65.4-70.1$ & $4.3-5.2$ \\
\hline P. multistriata & lanceolate & $26-30$ & $38-40$ & 2(3) & 12 & - & $60.2-70.3$ & $3.3-3.8$ \\
\hline $\begin{array}{l}\text { P. pseudo- } \\
\text { delicatissima }\end{array}$ & linear & $20-26$ & $36-45$ & 1 & $5-6$ & + & $65.5-69.0$ & $1.7-2.1$ \\
\hline P. subfraudulenta & linear & $15-18$ & $25-26$ & 2 & & + & $46.3-52.1$ & $4.2-4.9$ \\
\hline P. multiseries & lanceolate & $16-17$ & $16-17$ & $3(2-4)$ & $6-7$ & - & $80.0-85.2$ & $2.8-3.2$ \\
\hline \multirow[t]{2}{*}{ P. calliantha } & linear & $19-21$ & $32-36$ & 1 & $5-6$ & + & $58.2-68.1$ & $1.7-1.9$ \\
\hline & & $24-26$ & $44-45$ & 1 & $5-6$ & + & & \\
\hline P. dolorosa & lanceolate & $17-20$ & $30-37$ & $1(2)$ & 6 & + & $73.0-90.3$ & $2.2-2.8$ \\
\hline P. galaxiae & Lanceolate & $20-25$ & $68-70$ & n.d. & n.d. & + & $20.0-25.0$ & $1.3-1.6$ \\
\hline $\begin{array}{l}\text { P. pungens } \\
\text { var. aveirensis }\end{array}$ & n.d. & 16 & 16 & 2 & 4 & - & n.d. & $2.9-3.1$ \\
\hline P. cf. cacciantha & lanceolate & $18-21$ & $33-34$ & 1 & 5 & + & $72.0-75.0$ & $2.6-2.7$ \\
\hline
\end{tabular}

two main seasons for proliferation of Pseudo-nitzchia species, particularly those known to be producing DA. Eight and nine species were identified during spring and autumn, respectively (Fig. 4). During Pseudo-nitzschia bloom in May, P. arenysensis / P. delicatissima were significantly dominant at $65 \%$ while during the Pseudo-nitzschia bloom in October, several species of Pseudo-nitzschia proliferated but there were three dominating species $(P$. pseudodelicatissima, $P$. dolorosa and $P$. cuspidata) with lower values, reaching $20 \%, 18 \%$ and $17 \%$ respectively.

\section{Discussion}

This study was conducted in the M'diq Bay during 2007. The evolution of species composition of Pseudo-nitzschia was studied in comparison with the local evolution of DA detection in two shellfish species: tuberculate cockle (Acanthocardia tuberculata) and sweet clam (Challista chione). This study is the first for the Mediterranean coastline of Morocco.

It has been shown that there is a continuous presence of Pseudo-nitzschia spp. in M'diq Bay, characterized by 5 proliferation periods $\left(>20\right.$ cells $\mathrm{mL}^{-1}$ ) (March to November). The lower abundances were recorded during the rainy period (December - February). Similar results were found by QUIJANO-SCHEGGA et al. (2008) on the Spanish Mediterranean coast. According to LOUREIRO et al. (2009), the Pseudo-nitzschia abundance recorded in Catalonia in 2007 was similar to that recorded in this study in autumn, while in April, their reported value of Pseudo-nitzschia abundance is lower than in the present study. Perhaps the Pseudo-nitzschia bloom registered on the Spanish coast during April could be conducted by ocean currents to the Moroccan coast. 


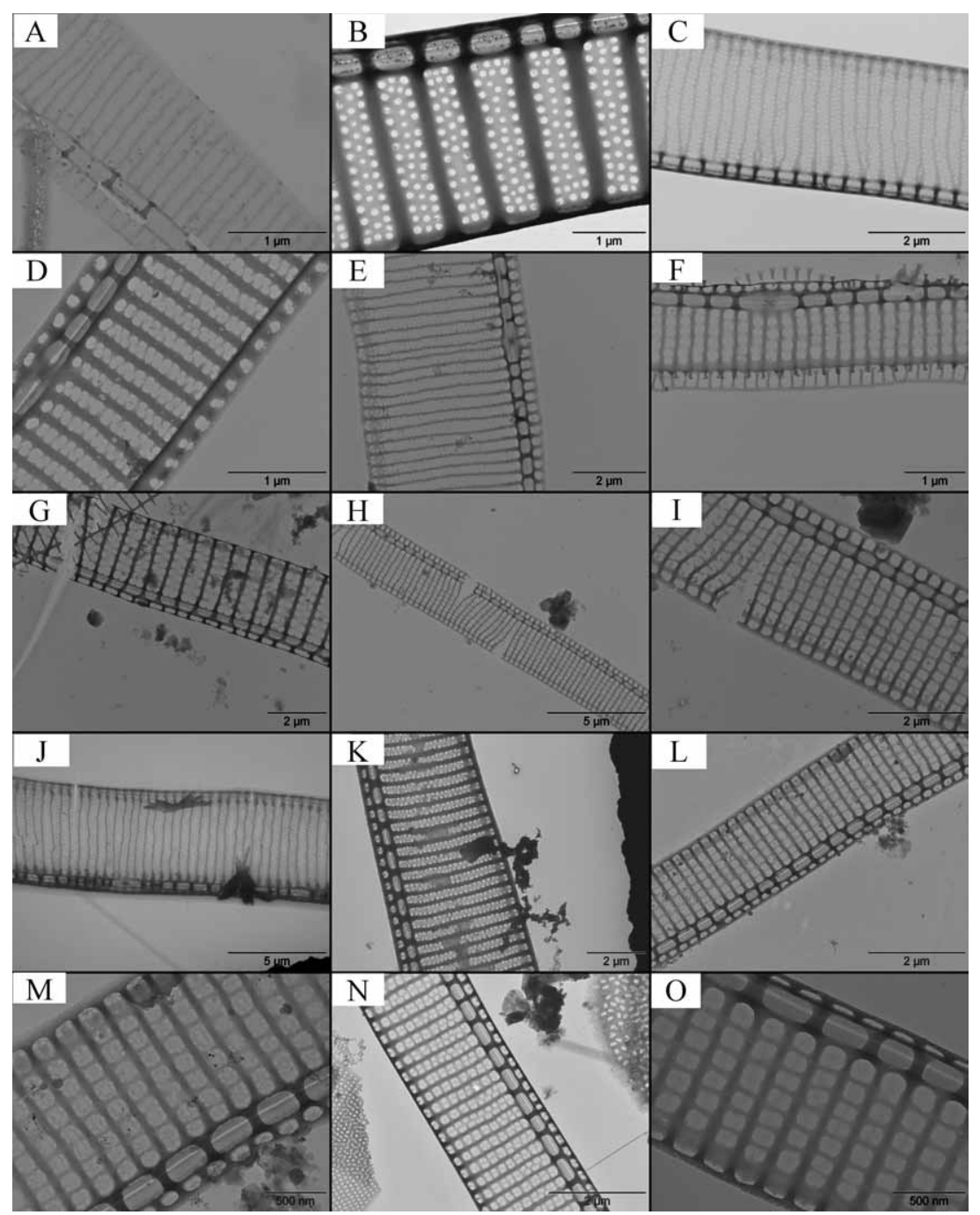

Fig. 3. Transmission electron micrographs of Pseudo-nitzschia spp. from M'diq Bay. A-P. galaxiae; $\mathrm{B}-$ P. multiseries; $\mathrm{C}-$ P. multistriata $; \mathrm{D}-$ P. arenysensis; $\mathrm{E}-P$. subpacifica; $\mathrm{F}-$ P. cuspidata; $\mathrm{G}-$ P. pungens var. aveirensis; $\mathrm{H}, \mathrm{I}-P$. cf. cacciantha; $\mathrm{J}-$ P. fraudulenta $; \mathrm{K}-$ P. subfraudulenta $; \mathrm{L}, \mathrm{M}-$ P. calliantha $\mathrm{N}-$ P. dolorosa $; \mathrm{O}-$ P. pseudodelicatissima.

In this study, the highest Pseudo-nitzschia abundance and DA concentration occurred in May and the end of September; both periods showing a transition between cold and warm seasons. Environmental condition changes seem likely to have boosted Pseudo-nitzschia development. It is possible that the M' diq bay area experienced an increase in nutrients during these periods. Several studies suggested that Pseudo-nitzschia blooms are associated with cool and high nutrient waters (TRAINER et al. 2000). Pseudo-nitzschia abundance has a positive correlation with water temperature, phosphate and ammonium (LJUBEŠIĆ et al. 2011). 


\begin{tabular}{|c|c|c|}
\hline 目 P.cuspidata & 國 P. subpacifica & $\square P$. arenysensis \\
\hline P. fraudulenta & $\square$ P. multistriata & $\square P$.pseudodelicatissima \\
\hline D. subfraudulenta & 图 P. multiseries & 固 P. calliantha \\
\hline 毘 P. dolorosa & 图 P. galaxiae & 目 P.pungens Var. aveirensis \\
\hline p.cf. cacciantha & 四 pseudo-nitzschia sp & \\
\hline
\end{tabular}

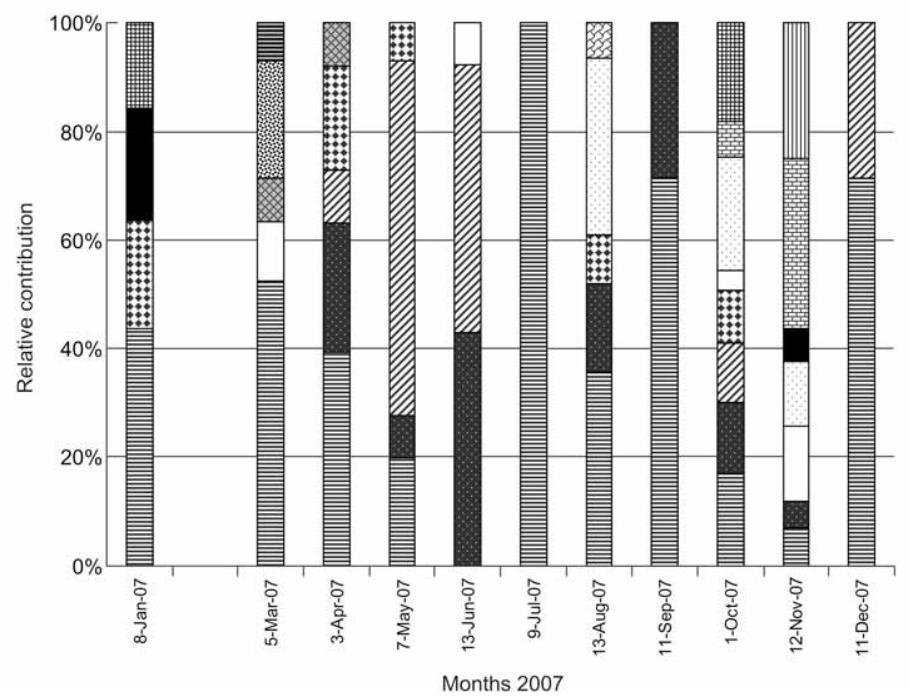

Fig. 4. Relative contributions of Pseudo-nitzschia species in M'diq Bay in the period January to December 2007.

In spring bloom ( 88 cells $\mathrm{mL}^{-1}$ ), we recorded DA presence in both the two studied shellfish species, showing a high value in sweet clam $\left(4.9 \mu \mathrm{g} \mathrm{DA} \mathrm{g}^{-1}\right)$ and low value in tuberculate cockle $\left(2.11 \mu \mathrm{g} \mathrm{DA} \mathrm{g}^{-1}\right)$. This variation of DA contamination between these two shellfish species could be related to their different biological characteristics; it seems that their specific receptors for DA could be different and have varying affinities for DA. The same explanation was given by SAGOU et al. (2005) for contamination by PSP toxins. During spring bloom, we observed four dominant Pseudo-nitzschia species: P. arenysensis (65\%) and $P$. cuspidata $(19 \%)$ as well as two species with lower abundance: P. fraudulenta $(7 \%)$ and $P$. subpacifica (9\%) (Fig. 4).

Eight identified species (Tab. 2, Fig. 3) are considered producers of DA (according to LunDHOLM et al. 2011). Domoic acid recorded in shellfish could be related to $P$. cuspidata and P. fraudulenta, as they are known to be DA producers (RHODES et al. 1996, RHODES 1998, Trainer et al. 2009, QuiJANO-SchegGia et al. 2010). For the other two species, $P$. subpacifica is not known to be a DA producer while the case of $P$. Arenysensis requires some clarification. Pseudo-nitzschia arenysensis is quite similar to P. delicatissima; it is not possible to distinguish between them using microscopic observation, only by genetic analysis (Quijano-Scheggia et al. 2008). Moreover, $P$. delicatissima is deemed to be toxic but $P$. arenysensis is not. Thus, the $65 \%$ of spring bloom, apparently taken by $P$. arenysensis, could be also composed partially or totally of $P$. delicatissima, which could produce DA and likely infect shellfish. 
In the autumn bloom, we recorded a Pseudo-nitzschia abundance reaching $157 \times 10^{3}$ cells. $\mathrm{L}^{-1}$ and composed of 8 Pseudo-nitzschia species, such as: P. pseudodelicatissima (20\%), P. dolorosa (18\%), P. cuspidata (17\%), P. subpacifica (13\%), P. arenysensis (10\%), $P$. fraudulenta (9\%), P. calliantha (6\%) and P. multistriata (3\%). Among these species, $P$. dolorosa has never been recognized as a DA producer while P. pseudodelicatissima (MARTIN et al. 1990, PAn et al. 2001, AmzIL et al. 2001), P. multistriata (RHODES et al. 2000, SARNO and Dahlmann 2000, Amato et al. 2010, QuiJANo-SchegGia et al. 2010) and $P$. calliantha (BesikTEPE et al. 2008, Alvarez et al. 2009, QuiJANO-SchegGiA et al. 2010) are already known to be DA producers.

Even if Pseudo-nitzschia bloom in autumn was the highest, DA concentration in both the two studied shellfish species was low and lower than that recorded in spring bloom: 1.57 $\mu \mathrm{g} \mathrm{DA} \mathrm{g}^{-1}$ in sweet clam and $0.75 \mu \mathrm{g} \mathrm{DA} \mathrm{g}^{-1}$ in tuberculate cockle. This difference of contamination between spring and autumn could be explained by both the difference in environmental conditions during spring and autumn periods and the differences in Pseudo-nitzschia species composing blooms. The production of DA is dependent on the concentration of nutrients (PAN et al. 1996, KLEIN et al. 2010).

The DA detected in tuberculate cockle and sweet clam was due to the presence of some toxic species such as $P$. multistriata, $P$. cuspidata, $P$. galaxiae, $P$. multiseries, $P$. pseudodelicatissima, $P$. pungens var. aveirensis, $P$. calliantha and $P$. fraudulenta. In the present study, the DA level measured in spring and autumn blooms did not exceed the normative threshold of $20 \mu \mathrm{g} \mathrm{DA} \mathrm{g}^{-1}$ of shellfish meat. In the literature, several blooms of Pseudo-nitzschia resulting in shellfish contamination by DA were studied. Taking into account the available literature on the Mediterranean Sea, the results of the present study, particularly in terms of shellfish DA concentrations, are not sufficient to suggest there is a danger to public health.

During 2007, a large diversity of Pseudo-nitzschia species was observed in M'diq Bay. Some of them have already been identified in Mediterranean waters while others are described for the first time: P. cuspidata, P. multiseries, P. subpacifica and P. subfraudulenta.

\section{Conclusion}

The present study has shown that there is a seasonal succession of thirteen species of Pseudo-nitzschia all the year round. Some of them have already been identified in Mediterranean waters while others are described for the first time: P. cuspidata, P. multiseries, $P$. subpacifica and $P$. subfraudulenta.

The highest abundance of Pseudo-nitzschia species was recorded in spring and autumn. Some of them are known to be producers of a large quantity of DA. During spring and autumn seasons, DA concentration in the two shellfish species studied, tuberculate cockle (Acanthocardia tuberculata) and sweet clam (Callista cheone), was higher in the latter than in the former. In M' diq bay, these two seasons have to be considered a potentially dangerous period for ASP events. However, much more work needs undertaking for the mechanisms of Pseudo-nitzschia species development in relationship with local environmental conditions to be understood. This study is in fact the first attempt at an assessment of Pseudo-nitzschia species succession and domoic acid production on the Moroccan Mediterranean Coast. 
Rujal Leblad B., Lundholm N., Goux D., Veron B., Sagou R., et al.

\section{References}

Akallal, R., Chantal, B., Jacqueline, F., Thierry, C., Mouradi, A., 2002: Contribution à l'étude du phytoplancton de la côte atlantique marocaine, II. Le Genre Pseudo-nitzschia (Bacillariophyceae). Cryptogamie, Algologie 23, 187-202.

Alvarez, G., Uribe, E., Quijano-Scheggia, S., Rivera, A. L., Marino, C., Blanco, J., 2009: Domoic acid production by Pseudo-nitzschia australis and Pseudo-nitzschia calliantha isolated from North Chile. Harmful Algae 8, 938-945.

AmAto, A., LÜDEKING, A., KooISTRA, W. H., 2010: Intracellular domoic acid production in Pseudo-nitzschia multistriata isolated from the Gulf of Naples (Tyrrhenian Sea, Italy). Toxicon 55,157-161.

Amzil, Z., Jaqueline, F., Dominique, L. G., Chantal, B., 2001: Domoic acid accumulation in French shellfish in relation to toxic species of Pseudo-nitzschia multiseries and $P$. pseudodelillcatissima. Toxicon 39, 1245-1251.

Bargu, S., Koray, T., Lunddholm, N., 2002: First report of Pseudo-nitzschia calliantha Lundholm, Moestrup \& Hassle 2003, a new potentially toxic species from Turkish coasts. Journal of Fisheries and Aquatic Sciences 19, 479-483.

Bates, S. S., Bird, C. J., De Freitas, A. S. W., Foxall, L. A., Hanic, L. A. Johnson, G. R., Mcculloch, A. W., Odense, P., Pocklington, R., Quilliam, M. A., Sim, P. G., Smith, J. C., Subba, RaO, D. V., Todd, E. C. D., Walter, J. A., Wright, J. L. C., 1989: Pennate diatom Nitzschia pungens as the primary source of domoic acid, a toxin in shellfish from eastern Prince Edward Island, Canada. Canadian Journal of Fisheries and Aquatic Sciences 46, 1203-1215.

Besiktepe, S., Larisa, R., Dilek, E., Doruk, Y., Arife, Z., Vitaly, R., Raisa, L., 2008: Domoic acid production by Pseudo-nitzschia calliantha Lundholm, Moestrup et Hasle (bacillariophyta) isolated from the Black Sea. Harmful Algae 7, 438-442.

BourhILI, E., 1984: Intoxication alimentaire par les Moules. (51 cas). Agadir octobre et novembre 1982. Thèse no. 33, Faculté de Médecine et Pharmacie, Rabat.

Caroppo, C., Congestri, R., Bracchini, L., Albertano, P., 2005: On the presence of Pseudo-nitzschia calliantha Lundholm, moestrup et Hasle and Pseudo-nitzschia delicatissima (Cleve) Heiden in the Southern Adriatic Sea (Mediterranean Sea, Italy). Journal of Plankton Research 27, 163-774.

Cerino, F., Orsini, L., Sarno, D., Carmela, D. A., Tartaglione, L., Zingone, A, 2005 : The alternation of different morphotypes in the seasonal cycle of the toxic diatom Pseudo-nitzschia galaxiae. Harmful Algae 4, 33-48.

EsSAID, E. F., 1977: L'intoxication paralytique par les fruits de mer. Thèse no. 44, Faculté Médecine et Pharmacie, Rabat.

HASLE, G. R., 2002: Are most of the domoic acid-producing species of the diatom genus Pseudo-nitzschia cosmopolites? Harmful Algae 1, 137-146.

Illoul, H., Maso, M., Fortuno, J. M., Cros, L., Morales-Blake, A., SÉRIDJi, R., 2008: Potentially harmful microalgae in coastal waters of the Algiers area (Southern Mediterranean Sea). Cryptogamie, Algologie 29, 261-278.

Inès, S., Asma, S. H., Bates, S. S., 2006: First detection of toxic Pseudo-nitzschia Calliantha in Bizert lagoon, Tunisia. Harmful Algae News 30, 8-9. 
Kaniou-Grigoriadou, I., Mouratidou, T., Katikou, P., 2005: Investigation on the presence of domoic acid in Greek shellfish. Harmful Algae 4, 717-723.

Klein, C., Claquin, P., Bouchart, V., Le Roy, B., Véron, B., 2010: Dynamics of Pseudo-nitzschia spp. and domoic acid production in a macrotidal ecosystem of the Eastern English Channel (Normandy, France). Harmful Algae 9, 218-226.

Luubešić, Z., Bosak, S., Viličić, D., Kralu Borojević, K., Marić, D., Godrijan, J., Ujević, I., Peharec, P., Duakovac, T., 2011: Ecology and taxonomy of potentially toxic Pseudo-nitzschia species in Lim Bay (north-eastern Adriatic Sea). Harmful Algae 10, 713-722.

Loureiro, S., Garés, E., Fernandz, T. M., Vaqué, D., CAmp, J., 2009: Pseudo-nitzschia spp. (Bacillariophyceae) and dissolved organic matter (DOM) dynamics in the Ebro Delta (Alfacs Bay, NW Mediterranean Sea). Estuarine, Coastal Shelf Science 83, 539-549.

LundHolm, N., (ed.) 2011: Bacillariophyta, in IOC-UNESCO Taxonomic Reference List of Harmful Micro Algae. Retrieved June 11, 2012, from http://www.marinespecies.org/ $\mathrm{HAB}$

Lundholm, N., NeILs, D., OJvind, M., 2002: Phylogeny of the Bacillariaceae with emphasis on the genus Pseudo-nitzschia (Bacillariophyceae) based on partial LSU rDNA. Journal of Phycology 37, 115-134.

Margalef, R., 1969: Composicion especifica del fitoplancton de la costa Catalano-levantina (mediterraneo occidental)) en 1962-1967. Investigacion of Pesquera 33, 345-380.

Marić, D., LuJbešić, Z., GodriJan, J., Viličić, D., Ujević, I., PreCAli, R., 2011: Blooms of the potentially toxic diatom Pseudo-nitzschia calliantha Lundholm, Moestrup \& Hasle in coastal waters of the northern Adriatic Sea (Croatia). Estuarine Coastal and Shelf Science $92,323-331$.

Martin, J. L., Haya, K., Burridge, L. E., Wildish, D. J., 1990: Nitzschia pseudodelicatissma a source of domoic acid in the Bay of Fundy, eastern Canada. Marine Ecology Progress Series 67, 177-182.

Massuti, M., Margalef, R., 1950: Introducciyn al studio del plankton marino. Patronato juan de la Cierva de Investigacion técnica, Barcelona.

Moschandreou, K. K., Papaefthimiou, D., Katikou, P., Kalopesa, E., Panou, A., NikolaiDIS, G., 2010: Morphology, phylogeny and toxin analysis of Pseudo-nitschia pseudodelicatissima (Bacillariophyceae) isolated from the Thermaikos Gulf, Greece. Phycologia 49, 260-273.

Orsini, L., Diana, S., Gabreille, P., Roberto, P., Jens, D., Marina, M., 2002: Toxic Pseudo-nitzschia multistriata (Bacillariophyceae) from the Gulf of Naples: morphology, toxin analysis and phylogenetic relationships with other Pseudo-nitzschia species. European Journal of Phycology 37, 247-257.

PAn, Y., SubBa, R. D. V., MAnN, K. H., LI, W. K. W., HARrison, W. G., 1996: Effects of silicate limitation on production of domoic acid, a neurotoxin, by the diatom Pseudo -nitzschia multiseries. II. Continuous culture studies. Marine Ecology Progress Series $131,235-243$.

Pan, Y., Michael, L. P., Mark, B., Moeller, P. D. R., Quay Dortch, Powell, C. L., Doucette, G. J., 2001: Pseudo-nitzschia sp. cf. pseudodelicatissima a confirmed pro- 
ducer of domoic acid from the northern Gulf of Mexico. Marine Ecology Progress Series 22, 83-92.

Quijano-Scheggia, S., Esther, G., Nagore, S., Kees, V. L., Eva, F., Karl, A., José-MAnuel, F., Jordi, C., 2008: Identification and characterisation of the dominant Pseudo-nitzschia species (Bacillariophyceae) along the NE Spanish coast (Catalonia, NW Mediterranean). Scientia Marina 72, 343-359.

Quijano-Scheggia, S., Esther, G., Karl, B. A., Pablo, D. L. I., Jorge, D., Jose-Manuel, F., JoRDI, C., 2010: Pseudo-nitzschia species on the Catalan coast: characterization and contribution to the current knowledge of the distribution of this genus in the Mediterranean Sea. Scientia Marina 74, 395-410.

Quilliam, M. A., XIE, M., HaRdStAFF, W. R., 1995: Rapid extraction and cleanup for liquid chromatographic determination of domoic acid in unsalted food. Journal of Aoac International 78, 543-554.

Rhodes, L. L., JAnet, A., Chris, S., 2000: Pseudo-nitzschia multistriata (Bacillariophyceae) in New Zealand; New Zealand Journal of Marine and Freshwater Research 34, 463-467.

Rhodes, L. L., White, D., Syhre, M., Atkinson, M., 1996: Pseudonitzschia species isolated from New Zealand coastal waters: domoic acid production in vitro and links with shellfish toxicity. In: Yasumoto, T., Oshima, Y., Fukuyo, Y. (ed), Harmful and toxic algal blooms, 155-158. Intergovernmental Oceanographic Commission of UNESCO, Paris.

RHodes, L. L., 1998: Identification of potentially toxic Pseudo-nitzschia (Bacillariophyceae) in New Zealand coastal waters, using lectins; New Zealand Journal of Marine and Freshwater Research 32, 537-544.

Sagou, R., Amnhir, R., Taleb, H., Vale, P., Blaghen, M., Loutfi, M., 2005: Comparative study on differential accumulation of PSP toxins between cockle (Aconthocardia tubercula) and sweet clam (Callista chione). Toxicon 46, 612-618.

SARnO, D., Dahlmann, J., 2000: Production of domoic acid in another species of Pseudo-nitzschia: P. multistriata in the Gulf of Naples (Mediterranean Sea). Harmful Algae News 21.

SPATHARIs, S., DANIELIDIs, D. B., TsirTsis, G., 2007: Recurrent Pseudo-nitzschia calliantha (Bacillariophyceae) and Alexandrium insuetum (Dinophyceae) winter blooms induced by agricultural runoff. Harmful Algae 6, 811-822.

Taleb, H., Vale, P., Jaime, E., Blaghen, M., 2001: Study of paralytic shellfish poisoning toxin profile in shellfish from the Mediterranean shore of Morocco. Toxicon 39, 1855-1861.

Trainer, V. L., Adams, N. G., Bill, B. D., Stehr, C. M., Wekell, J. C., Moeller, P., BusMAN, M., WoOdRUFF, D., 2000: Domoic acid production near California coastal upwelling zones. Limnology and Oceanography 45, 1818-1833.

Trainer, V. L., Hickey, B. M., Lessard, E. J., Cochlan, W. P., Trick, C. G., Wells, M. L., MacFadyen, A., Moore S. K., 2009: Variability of Pseudo-nitzschia and domoic acid in the Juan de Furca eddy region and its adjacent shelves. Limnology and Oceanography 51, 289-308. 
Ujević, I., NinČević-Gladan, Ž., RoJe, R., Skejić, S., Arapov, J., Marasović, I., 2010: Domoic acid - A new toxin in the Croatian Adriatic shellfish toxin profile. Molecules 15, 6835-6849.

UTERMÖHL, H., 1958: Zur Vervollkommnung der quantitative Phytoplankton Methodik. Mitteilungen Internationale Vereinigung für Theoretische und Angewandte Limnologie 9, 1-38.

Wright, J. L. C., Boyd, R. K., Freitas, A. S. W., Falk, M., Foxall, R. A., Jamieson, W. D., layock, M. V., McCulloch, A. W., Maclnnes, A. G., Odense, P., PathaK, V. P., Quilliam, M. A., Ragan, M. A., Sim, P. G., Thibaut, P., Walter, J. A., Gilgan, M., RichARD, D. J. A., DEWAR, D., 1989: Identification of domoic acid, a neurotoxic amino acid, in mussels from eastern Prince Edward Island. Canadian Journal of Chemistry 67, 481-490.

Zapata, M., Rodriguez, F., Fraga, S., Barra, L., Ruggiero, M. V., 2011: Chlorophyll C pigment patterns in 18 species (51 strains) of the genus Pseudo-nitzschia (Bacillariophyceae). Journal of Phycology 47, 1274-1280.

Zingone, A., Siano, R., D’ Alelio, D., Sarno, D., 2006: Potentially toxic and harmful microalgae from coastal waters of the Campania region (Tyrrhenian Sea, Mediterranean Sea). Harmful Algae 5, 321-337. 
Acta Bot. Croat. $72(1), 49-69,2013$

\title{
Karyological and morphological variations within the genus Dysphania (Chenopodiaceae) in Bulgaria
}

\author{
Neli H. Grozeva ${ }^{1}$, Yanka G. Cvetanova ${ }^{2}$ \\ ${ }^{1}$ Department of Biology and Aquaculture, Agriculture Faculty, Trakia University, \\ Stara Zagora, Bulgaria \\ ${ }^{2}$ Department of Informatics and Mathematics, Faculty of Economics, Trakia University, \\ Stara Zagora, Bulgaria
}

\begin{abstract}
The karyological and morphological variability of species from the genus Dysphania were studied. The results demonstrated that genus Dysphania is represented in Bulgaria by five species: Dysphania ambrosioides, D. multifida, D. botrys, D. schraderi$a n a$ and $D$. pumilio. The first two species are tetraploids with chromosome number $2 n=32$ for $D$. ambrosioides and $2 n=36$ for $D$. multifida. The remaining three species are diploids with $2 n=18$. The results from statistical analysis demonstrated that the main source of phenotype variation in the species is the interpopulation variation. The specific characters which allowed their recognition are the morphological characteristics of the perianth lobes, the upper leaves and the seeds. The distinction between D. multifida, D. ambrosioides and $D$. schraderiana is based on differences in the quantitative traits, while in $D$. botrys and $D$. pumilio qualitative traits are also important. The basic evolutionary mechanisms are polyploidy and diploidy. A tendency towards reduction in the size of generative organs and the number of perianth lobes was found.
\end{abstract}

Key words: Dysphania, distribution, ecology, karyology, morphology, Bulgaria

\section{Introduction}

Traditionally, the genus Dysphania comprises 6-10 species, endemic for Australia (Mosyakin 1993, Clements and Mosyakin 2003, Zhu et al. 2003). Over the past decades, the systemic definition and composition of the genus has frequently been a subject of discussion (MosYAKIN 1993; MosYAKIN and CLEMENTS 1996, 2002, 2008). Currently the genus Dysphania comprises about 40 species that earlier constituted the subgenus Ambrosia of the genus Chenopodium or were referred to the genera: Neobotritium Moldenke, Roubieva Moquin-Tandon, Teloxys Moquin-Tandon. The representatives of the genus are mainly ruderal and weed plants, more common in the tropics, subtropics and warm-temperature

* Corresponding author, e-mail: grozeva@uni-sz.bg

Copyright $^{\circledR} 2013$ by Acta Botanica Croatica, the Faculty of Science, University of Zagreb. All rights reserved. 
zone. Most of them entered Europe through the import of wool and agricultural products from Australia, South America, Eastern Asia, and Africa. A number of researchers (AELLEN 1960, Uotila and SuOMinen 1976, Dostalek 1985, KüHn 1993, Uotila 2001) pointed out their great morphological variability, especially prominent in the leaf lamina. The similar, rarely exceeding $1 \mathrm{~mm}$, dimensions of the generative organs very often make their distinction difficult.

For the Bulgarian flora so far five species have been reported - Chenopodium ambrosioides L. (= Dysphania ambrosioides (L.) Mosyakin et Clements), C. botrys L. (= Dysphania botrys (L.) Mosyakin et Clements), C. multifidum L. (= Dysphania multifida (L.) Mosyakin et Clements), C. pumilio R. Br. (= Dysphania pumilio (R. Br.) Mosyakin et Clements) and C. schraderianum Schult. (= Dysphania schraderiana (Schult.) Mosyakin et Clements) (Markova 1966, Assyov and Petrova 2006, Grozeva 2007).

Dysphania ambrosioides forms populations on open sandy terrain, in close proximity to water basins from sea level to $250 \mathrm{~m}$ above sea level. It is usually a dominant species in anthropophyte or ruderal communities.

D. multifida forms populations on open lowland areas, more rarely on those facing west or south at altitudes from sea level to $700 \mathrm{~m}$ above sea level. It dominates or is an accompanying species in anthropophyte or ruderal communities dominated by cereal species.

$D$. botrys is widely spread on open, sunlit areas and as a weed in cultivated crops at altitudes from sea level to $900 \mathrm{~m}$ above sea level. Most often, it dominates or is an accompanying species in ruderal communities.

D. schraderiana was established for the Bulgarian flora by Pertti Uotila in 1993 while revising the materials from the genus Chenopodium in the herbarium of the Biological Faculty at Sofia University (SO). The species has very limited distribution. So far, only two populations have been known located in Vitosha and in Sredna Gora Mountain. Its ecological requirements are quite similar to these of $D$. botrys and specimens from both species were recorded in the population under study.

D. pumilio occurs in single localities in the Eastern Balkan Range, Thracian Lowland, Northeast Bulgaria, Black Sea Coast and Tundzha Hilly Country as an accompanying species in ruderal communities (Grozeva 2007, Vladimirov and Petrova 2010, Vladimirov 2011). The species forms populations in open sunlit places at an altitude from 168 to $850 \mathrm{~m}$.

The objective of this study was to investigate the patterns and levels of morphological variation, chromosome numbers and karyotype morphology as well as ecological conditions of the natural local Bulgarian populations of genus Dysphania, and to attempt to trace the relationships between the species and some evolutionary trends in the genus.

\section{Materials and methods}

Morphological and karyological analyses were carried out on 27 natural Bulgarian populations of the genus Dysphania, referred to five species: Dysphania ambrosioides, D. botrys, $D$. multifida, D. pumilio, and $D$. schraderiana. Thirty plants from each population were used in the overall research.

Chromosome numbers and karyotypes have been reported on lasting preparations of metaphase root apex plates of seeds germinated in laboratory conditions collected in the nat- 
ural habitats of the species. The root tips were treated and squashed according to the accepted methods (Grozeva 2007). The chromosomal type was determined after the centromere index I $=\mathrm{s} / \mathrm{s}+1$, according to the classification proposed by GRIF and AGAPOVA (1986). Three metaphase plates have been measured from each population. The voucher specimens are kept in the herbarium of the Bulgarian Academy of Sciences (SOM).

Twenty-four quantitative characters were included in the morphological analysis: 1 . Height of plant; 2. Length of basal leaf; 3. Width of basal leaf; 4. Length/width ratio; 5. Length of basal leaf petiole; 6 . Length of upper leaf; 7 . Width of upper leaf; 8 . Length/width ratio; 9 . Length of upper leaf petiole; 10 . Length of inflorescence; 11 . Length of flower petiole; 12. Diameter of flower; 13. Length of perianth lobes in bisexual flower; 14. Width of perianth lobes in bisexual flower; 15 . Length of perianth lobes in female flower; 16 . Width of perianth lobes in female flower; 17. Length of seed; 18 . Width of seed; 19. Length/width ratio; 20. Thickness of seed; 21. Length of fruit; 22. Width of fruit; 23. Length/width ratio; 24. Thickness of fruit. The following qualitative features were employed too: colour of stem; type of inflorescence; degree of perianth concrescence; presence of keeled perianth lobes; colour of perianth, seed and pericarp.

The mean value and coefficient of variation were calculated for each character of every population. They were used in the comparative analyses on different levels.

The relative contributions of intra- and interpopulation variation to the overall variation of each characteristic of the studied species were evaluated by one-way ANOVA.

Unweighted pair-group average (UPGA) hierarchical cluster analysis (HCA) was applied to the matrix with the Euclidean distances between the populations of the genus Dysphania in order to study the morphological pair-wise similarities and the underlying hierarchical classification structure.

The discriminant function analysis was conducted on morphological data to determine the most parsimonious way to distinguish between species. The stepwise discriminant analysis (SDA) procedure was used as it allows recognition of the most effectively discriminating variables among a large set of morphological characters.

Statistica 6.0 (StatSoft Inc. 2001) was used for the statistical analysis of morphological data.

\section{Results}

\section{Karyology}

As a result of karyological study, 3 chromosome numbers: $2 n=18,32,36$ have been found in the genus Dysphania (Tab. 1). Two types of chromosomes: metacentric and submetacentric have been established in the karyotypes.

The number $2 n=18$ has been counted in three species - Dysphania botrys, D. pumilio and $D$. schraderiana. The last species was studied karyologically in Bulgaria for the first time and for the studied population karyotype $2 n=14 \mathrm{~m}+4 \mathrm{sm}=18$ chromosomes has been established (Plate 1A). The diploid chromosome number found for D. schraderiana confirms the data known from literature sources (KJELLMARK 1934, SCHWARZOVA 1978a). For all three populations of $D$. pumilio the karyotype of $2 n=8 \mathrm{~m}+10 \mathrm{sm}=18$ chromosomes has been recorded (Plate 1B). The chromosome number $2 n=18$ found for the Bulgarian popu- 
Tab. 1. Description of studied populations of genus Dysphania. * - data published by GROZEVA and StOEVA (2006). ** - data published by GROZEVA (2007)

\begin{tabular}{ccc}
\hline $\begin{array}{c}\text { Section, species } \\
\text { and population } \\
\text { number }\end{array}$ & $2 n \quad$ Locality \\
\hline
\end{tabular}

Sect. Adenois (Moq.) Mosyakin et Clements.

Dysphania ambrosioides (L.) Mosyakin et Clemants

№201 32** Danubian plain, island Milka near Belene town, at $27 \mathrm{~m}, 43^{\circ} 40^{\prime} \mathrm{N}$, $25^{\circ} 10^{\prime} \mathrm{E}$, in sandy hair

№32 32** Thracian Lowland, Plovdiv town, near the river Maritza, at $164 \mathrm{~m}$, $42^{\circ} 09^{\prime} \mathrm{N}, 24^{\circ} 45^{\prime} \mathrm{E}$, in ruderal places

№104 32** Thracian Lowland, the locality Ostrova near Plovdiv town, at $164 \mathrm{~m}$, $42^{\circ} 09^{\prime} \mathrm{N}, 24^{\circ} 45^{\prime} \mathrm{E}$, in ruderal places

Dysphania multifida (L.) Mosyakin et Clemants

№39 36 Danubian plain, Island Goljama Barzina near Belene town, at $20 \mathrm{~m}$, $43^{\circ} 40^{\prime} \mathrm{N}, 25^{\circ} 10^{\prime} \mathrm{E}$, in outskirts of the island and on sandy hair

№40 36 Danubian plain, Vidin town, at $345 \mathrm{~m}, 43^{\circ} 59^{\prime} \mathrm{N}, 22^{\circ} 52^{\prime} \mathrm{E}$, in ruderal places near the bus station with Trifolium album and other legumes.

№105 36 Central Balkan Range, Kalofer town, at 666 m, 42 37’ N,24 59’ E, grasslands with Lolium perenne L. of $50 \mathrm{~m}$ from post

№106 36** Western Sredna Gora Mt., Ikhtiman town, at $658 \mathrm{~m}, 42^{\circ} 09^{\prime} \mathrm{N}$, $24^{\circ} 45^{\prime} \mathrm{E}$, in ruderal places in the western parts of the city together with cereal species

№107 36** Eastern Rhodope Mts, Ivaylovgrad town, at $104 \mathrm{~m}, 41^{\circ} 32^{\prime} \mathrm{N}, 26^{\circ} 08^{\prime} \mathrm{E}$, in ruderal places together with Bromus tectorum L. and Setaria viridis

№108 36 Thracian Lowland, Purvomay town, at $134 \mathrm{~m}, 42^{\circ} 06^{\prime} \mathrm{N}, 2^{\circ} 13^{\prime} \mathrm{E}$, grasslands in kvartal Debar.

№109 36** Thracian Lowland, Asenovgrad town, at $104 \mathrm{~m}, 42^{\circ} 01^{\prime} \mathrm{N}, 2^{\circ}{ }^{\circ} 52^{\prime} \mathrm{E}$, in ruderal places together with Setaria viridis

Sect. Botryoides (C. A. Mey) Mosyakin et Clemants

Dysphania botrys (L.) Mosyakin et Clemants

№29 18 Northern Black Sea Coast, around Varnensko ezero lake, at $79 \mathrm{~m}$, $43^{\circ} 11^{\prime} \mathrm{N}, 27^{\circ} 50^{\prime} \mathrm{E}$, periodically flooded coastal alluvial sands deposits

№97 18 Southern Black Sea Coast, Pomorie town, at $0 \mathrm{~m}, 42^{\circ} 35^{\prime} \mathrm{N}, 2^{\circ} 37^{\prime} \mathrm{E}$, in ruderal places near Monastery of Saint George

№100 18** North-Eastern Bulgaria, Razgrad town, at $200 \mathrm{~m}, 43^{\circ} 46^{\prime} \mathrm{N}, 26^{\circ} 31^{\prime} \mathrm{E}$, between the sidewalk and fences together with Polygonum aviculare

№35 18** Danubian plain, Belene town, at $35 \mathrm{~m}, 43^{\circ} 39^{\prime} \mathrm{N}, 25^{\circ} 07^{\prime} \mathrm{E}$, in ruderal places near the fishing pier

№102 18 Easthern Balkan Range, Natural park »Sinite kamani«, at 290 m, $42^{\circ} 42^{\prime} \mathrm{N}, 26^{\circ} 21^{\prime} \mathrm{E}$, in ruderal places near road from hotel Ablanovo to the lake Asenovets

№99 18** Central Balkan Range, Trojan town, at $400 \mathrm{~m}, 43^{\circ} 53^{\prime} \mathrm{N}, 24^{\circ} 43^{\prime} \mathrm{E}$, in ruderal places from $50 \mathrm{~m}$ to bus station 
Tab. 1. - continued

\begin{tabular}{|c|c|c|}
\hline $\begin{array}{l}\text { Section, species } \\
\text { and population } \\
\text { number }\end{array}$ & $2 n$ & Locality \\
\hline №98 & 18 & $\begin{array}{l}\text { Sofia region, Malo Buchino village, at } 748 \mathrm{~m}, 42^{\circ} 41^{\prime} \mathrm{N}, 23^{\circ} 10^{\prime} \mathrm{E} \text {, } \\
\text { along the sidewalk between the plates together with Polygonum } \\
\text { aviculare and Cynodon dactylon (L.) Pers. }\end{array}$ \\
\hline №101 & 18 & $\begin{array}{l}\text { Struma valley, Blagoevgrad town, at } 360 \mathrm{~m}, 41^{\circ} 45^{\prime} \mathrm{N}, 23^{\circ} 25^{\prime} \mathrm{E} \text {, weed } \\
\text { in the cultural community }\end{array}$ \\
\hline №53 & 18 & $\begin{array}{l}\text { Easthern Sredna Gora Mt., Gorno Novo selo village, at } 597 \mathrm{~m} \text {, } \\
42^{\circ} 27^{\prime} \mathrm{N}, 25^{\circ} 14^{\prime} \mathrm{E} \text {, in ruderal places near the road for a hut } \\
\text { Kavakliika together with Cynodon dactylon. }\end{array}$ \\
\hline №30 & 18 & $\begin{array}{l}\text { Thracian Lowland, Plovdiv town, near the river Maritza, at } 164 \mathrm{~m} \text {, } \\
42^{\circ} 09^{\prime} \mathrm{N}, 24^{\circ} 45^{\prime} \mathrm{E} \text {, in ruderal places }\end{array}$ \\
\hline №34 & 18 & $\begin{array}{l}\text { Thracian Lowland, Malka Vereja village, at } 235 \mathrm{~m}, 42^{\circ} 24^{\prime} \mathrm{N}, 25^{\circ} 33^{\prime} \mathrm{E} \text {, } \\
\text { in ruderal places at the eastern edge of the village together with } \\
\text { Atriplex tatarica L. and Setaria viridis (L.) Beauv }\end{array}$ \\
\hline №45 & 18 & $\begin{array}{l}\text { Thracian Lowland, Tselina village, at } 193 \mathrm{~m}, 42^{\circ} 07^{\prime} \mathrm{N} 25^{\circ} 27^{\prime} \mathrm{E} \text {, weed } \\
\text { in the cultural community }\end{array}$ \\
\hline \multicolumn{3}{|c|}{ Dysphania schraderiana (Schult.) Mosyakin et Clemants } \\
\hline №103 & 18 & $\begin{array}{l}\text { Easthern Sredna Gora Mt., near Kavakliika hut, } \\
\text { at } 650 \mathrm{~m}, 42^{\circ} 27^{\prime} \mathrm{N}, 25^{\circ} 12^{\prime} \mathrm{E} \text {, in ruderal places around the hut of } \\
\text { forestry together with Dysphania botrys }\end{array}$ \\
\hline \multicolumn{3}{|c|}{ Sect. Orthospora (R. Br.) Mosyakin et Clemants } \\
\hline \multicolumn{3}{|c|}{ Dysphania pumilio (R. Br.) Mosyakin et Clemants } \\
\hline №214 & $18 *$ & $\begin{array}{l}\text { Eastern Balkan Range, Sinite kamani Natural Park, at } 850 \mathrm{~m}, 42^{\circ} 42^{\prime} \mathrm{N} \text {, } \\
25^{\circ} 20^{\prime} \mathrm{E} \text {, in ruderal places by roadsides together with Polygonum } \\
\text { aviculare L. }\end{array}$ \\
\hline №217 & 18 & $\begin{array}{l}\text { Thracian Lowland, Stara Zagora town, at } 195 \mathrm{~m}, 42^{\circ} 25^{\prime} \mathrm{N}, 25^{\circ} 38^{\prime} \mathrm{E} \text {, } \\
\text { in ruderal places together with Dysphania botrys }\end{array}$ \\
\hline $\mathrm{N}-221$ & 18 & $\begin{array}{l}\text { Thracian Lowland, Chirpan town, at } 168 \mathrm{~m}, 42^{\circ} 25^{\prime} \mathrm{N}, 25^{\circ} 38^{\prime} \mathrm{E} \text {, in } \\
\text { ruderal places together with cereal plants }\end{array}$ \\
\hline
\end{tabular}

lations of $D$. pumilio corresponds to the data of JAVOURKOVA-JAROMIROVA (1992) and MesíčEK (1992) from the Czech Republic, SchwARZovÁ (1978b) from Slovakia and RAHIMENIJAD (2004) from Iran. With the third diploid species D. botrys differences have been recorded in the karyotype of the various populations. In population No. 29 from the Varna lake and population No. 30 from Plovdiv the karyotype consists of $2 n=4 \mathrm{~m}+14 \mathrm{sm}=$ 18 chromosomes (Plate 1C). In population No. 99 from Troyan and population No. 45 from Tselina satellites can be seen on one pair of submetacentric chromosomes (Plate 1D). In the remaining eight populations (Tab. 1), a karyotype of 18 submetacentric chromosomes has been established. In four of these populations (No. 97 from Pomorie; No. 102 from »Sinite kamani« Natural Park; No. 53 from Gorno Novo selo; No. 100 from Razgrad) one of the chromosome pairs has satellites (Plate 2A), while in the other four (No. 35 from Belene; No. 
Grozeva N. H., Cvetanova Y. G.
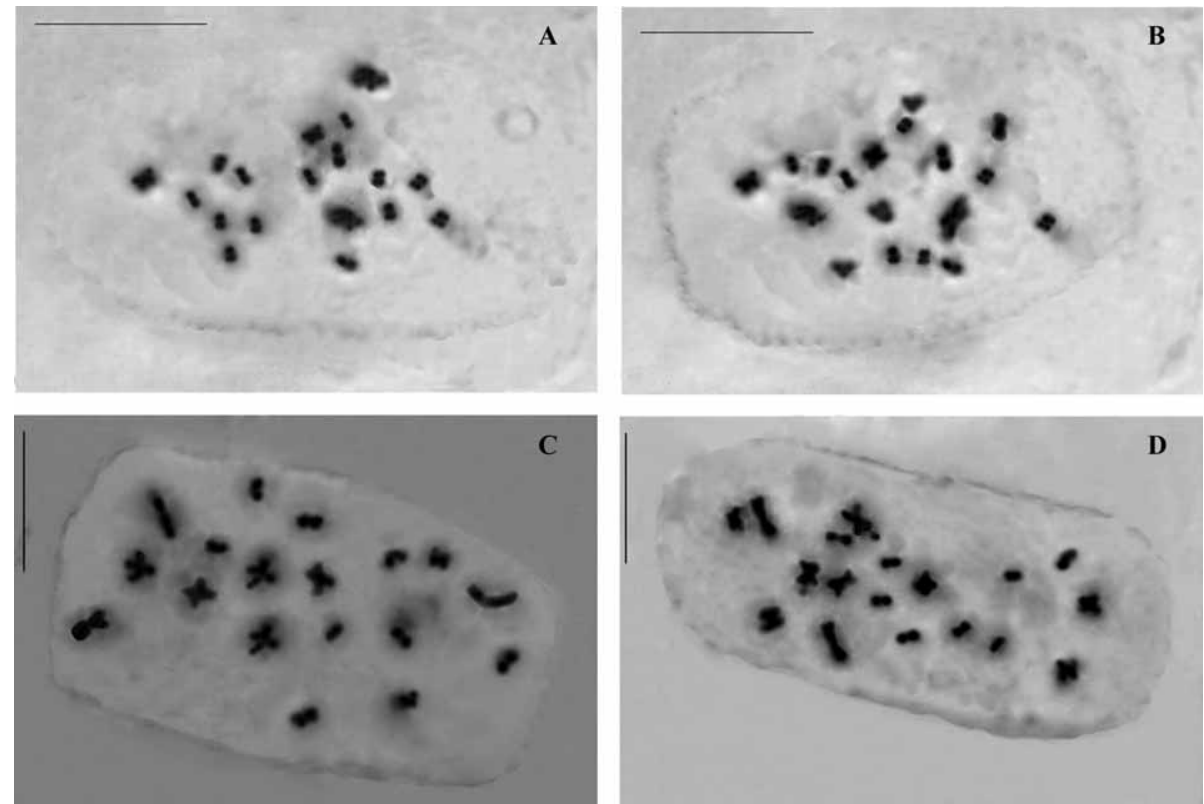

Plate 1. Microphotographs of the metaphase plate of Dysphania species: A - D. schraderiana (population № 103) $-2 n=18 ; \mathbf{B}-D$. pumilio (№ 221) $-2 n=18 ; \mathbf{C}-D$. botrys (№ 29) $-2 n=18$; D - D. botrys (№ 45) $-2 n=18$. - Scale bars $=10 \mu \mathrm{m}$.
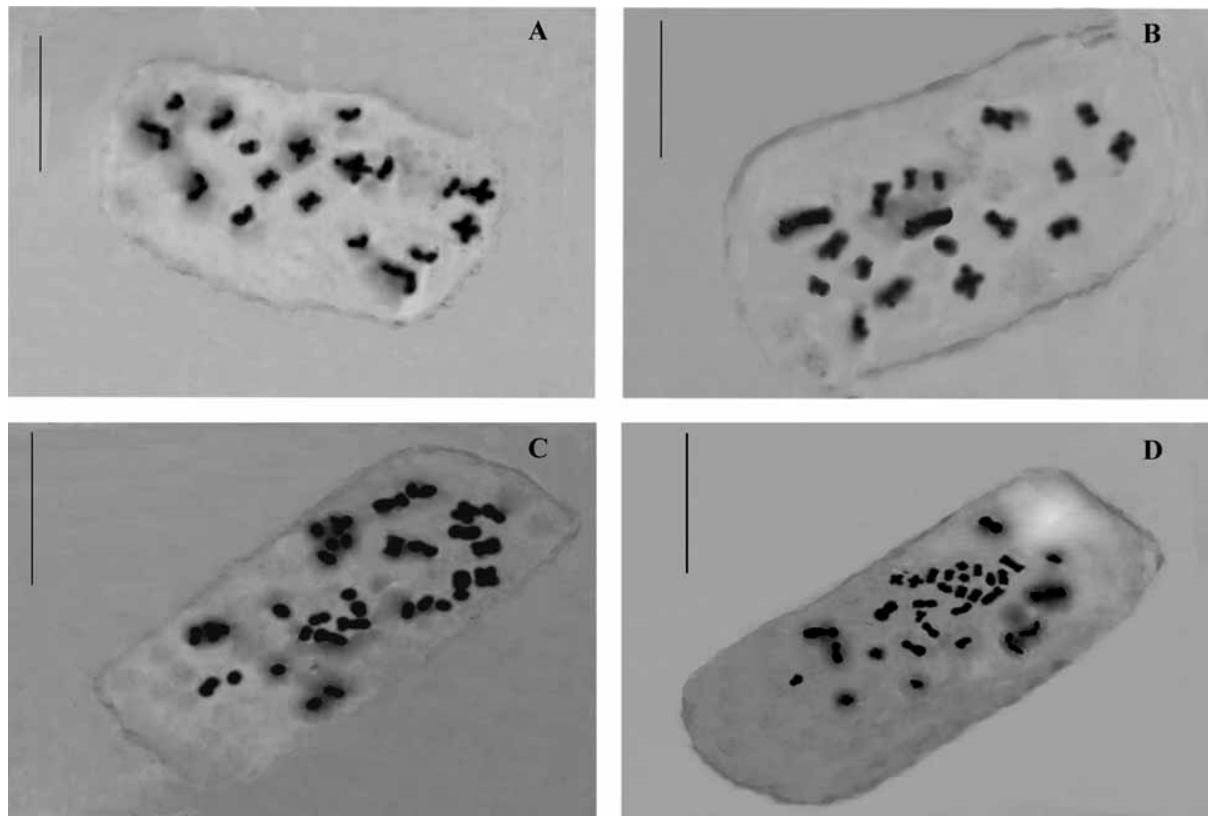

Plate 2. Microphotographs of the metaphase plate of Dysphania species: A-D. botrys (population № $53)-2 n=18 ; \mathbf{B}-D$. botrys (№ 98) $-2 n=18 ; \mathbf{C}-D$. ambrosioides (№ 102) $-2 n=32 ; \mathbf{D}-D$. ambrosioides (№ 201) $-2 n=32$. - Scale bars $=10 \mu \mathrm{m}$. 
98 from Malo Buchino; No. 34 from Malka Vereya; No. 101 from Blagoevgrad) satellites have not been found (Plate $2 \mathrm{~B}$ ). The chromosome number $2 n=18$ registered for the Bulgarian populations of $D$. botrys confirms the familiar reference data (MULLIGAN 1961; MEHRA and MALIK 1963; KeENER 1970; BASSET and CROMPTON 1971, 1982; Uotila 1973; QueIRos 1975, Schwarzová 1978b, 1980, 1993; DvořáK et al. 1980; KHATOON and Ali 1993; LOMONOSOVA et al. 2003).

The tetraploid chromosome number $2 n=32$ has been found for Dysphania ambrosioides. The same result has been found in various regions in the geographical area of the species (LORZ 1937; Woroschilov 1942; KAWATANI and OHNO 1950; RAGHAVAN and ARORA 1958; Mehra and Malik 1963; Sharma and Dey 1967; Murín and Ferakova 1974; QueIros 1975; Schwarzová 1978b, 1986; Silvestre 1984; Dvoř́́K 1989; KHATOON and Ali 1993; AL-TURKI et al. 1999, 2000). For the three studied populations, differences were recorded in the karyotype structure. In the two populations from the Thracian lowland (No. 32 from Plovdiv and No. 104 from an island on the Maritsa River) the karyotype consists of $2 n=20 \mathrm{~m}+12 \mathrm{sm}=32$ chromosomes (Plate 2C). For the population from the Danubian plain (No. 201 from the island of Milka) a karyotype of $2 n=4 \mathrm{~m}+28 \mathrm{sm}=32$ chromosomes has been established (Plate 2D).

The highest chromosome number $2 n=36$ is registered in the populations of $D$. multifida (Tab. 1). The same number was reported by MARKOVA (1968) for another Bulgarian population of the species from the village of Koshava in the Danubian plain. The data from the other parts of its habitat are for $2 n=32$ (KAWATANI and OHNO 1956; GIUSTI 1970; QueIRos 1975; GRANADO et al. 1988). In four of the studied populations (No. 39 from the island of Golyama Barzina, No. 108 from Parvomay, No. 105 from Kalofer, and No. 109 from Asenovgrad) the karyotype of $2 n=20 \mathrm{~m}+16 \mathrm{sm}=36$ chromosomes has been registered (Plate 3A). In the other three populations (No. 40 from Vidin, No. 106 from Ihtiman, No. 107 from Ivaylovgrad) the karyotype of $2 n=16 \mathrm{~m}+20 \mathrm{sm}=36$ chromosomes has been established (Plate 3B).
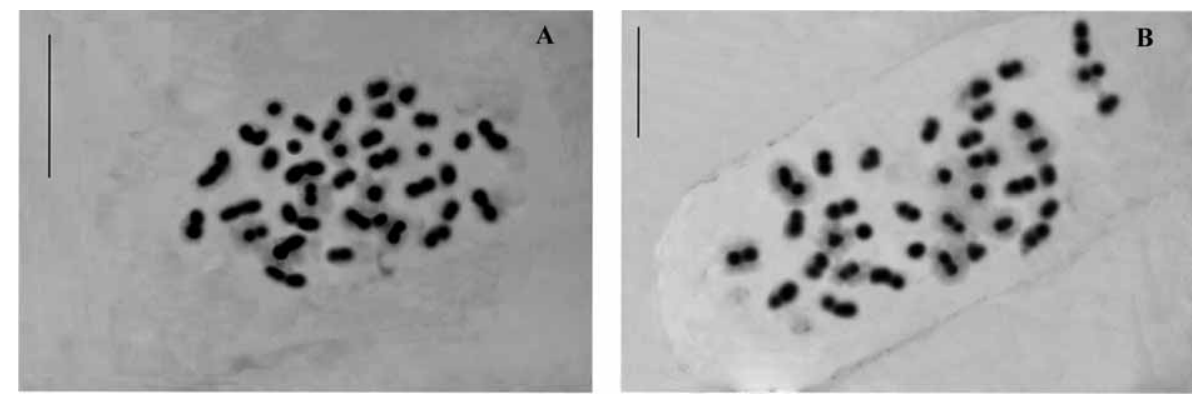

Plate 3. Microphotographs of the metaphase plate of Dysphania species: A - D. multifida (population № 105) $-2 n=36 ; \mathbf{B}-D$. multifida (№ 40) $-2 n=36$. - Scale bars $=10 \mu \mathrm{m}$.

\section{Morphology}

The intrapopulation variation was estimated on the basis of the coefficient of variation (Tabs. 2-4). The data show that in all populations vegetative have higher level of variability than generative traits. 
Grozeva N. H., Cvetanova Y. G.

Tab. 2. Mean (first line) and coefficient of variation in \% (second line) of Dysphania schraderiana (103), D. pumilio $(214,217,221)$, D. ambrosioides $(201,32,104)$ populations for each of the 24 observed characters

\begin{tabular}{|c|c|c|c|c|c|c|c|}
\hline & \multicolumn{7}{|c|}{ Populations } \\
\hline & 103 & 214 & 217 & 221 & 201 & 32 & 104 \\
\hline \multirow[t]{2}{*}{1} & 79.3 & 41.2 & 34.29 & 30.1 & 52.1 & 77.0 & 65.4 \\
\hline & 17.5 & 36.9 & 28.39 & 37.2 & 34.1 & 27.0 & 15.8 \\
\hline \multirow[t]{2}{*}{2} & 5.6 & 2.6 & 2.17 & 2.0 & 4.5 & 4.1 & 4.0 \\
\hline & 27.4 & 38.7 & 13.25 & 32.2 & 20.2 & 22.9 & 20.3 \\
\hline \multirow[t]{2}{*}{3} & 3.5 & 1.3 & 1.24 & 1.2 & 1.1 & 1.2 & 1.1 \\
\hline & 23.4 & 28.3 & 22.41 & 31.3 & 25.2 & 21.6 & 21.3 \\
\hline \multirow[t]{2}{*}{4} & 1.6 & 2.3 & 1.73 & 1.3 & 4.5 & 3.7 & 3.8 \\
\hline & 12.1 & 38.2 & 17.82 & 16.8 & 27.3 & 25.7 & 24.3 \\
\hline \multirow[t]{2}{*}{5} & 1.5 & 1.4 & 1.39 & 1.3 & 0.6 & 0.54 & 0.3 \\
\hline & 13.0 & 42.3 & 47.3 & 32.3 & 33.3 & 37.9 & 13.6 \\
\hline \multirow[t]{2}{*}{6} & 3.0 & 0.9 & 0.84 & 0.7 & 1.9 & 2.0 & 1.8 \\
\hline & 8.6 & 32.1 & 11.97 & 23.9 & 23.7 & 30.4 & 18.4 \\
\hline \multirow[t]{2}{*}{7} & 1.4 & 0.5 & 0.39 & 0.3 & 0.4 & 0.5 & 0.4 \\
\hline & 11.3 & 27.4 & 18.18 & 23.9 & 23.6 & 36.2 & 15.9 \\
\hline \multirow[t]{2}{*}{8} & 2.2 & 1.5 & 1.52 & 1.4 & 5.8 & 4.5 & 5.1 \\
\hline & 6.9 & 44.2 & 21.34 & 19.8 & 25.2 & 29.0 & 21.0 \\
\hline \multirow[t]{2}{*}{9} & 0.3 & 0.5 & 0.53 & 0.6 & 0.4 & 0.3 & 0.1 \\
\hline & 26.2 & 35.2 & 12.30 & 14.6 & 32.7 & 35.8 & 23.0 \\
\hline \multirow[t]{2}{*}{10} & 50.9 & 21.7 & 19.94 & 15.1 & 29.6 & 45.4 & 40.8 \\
\hline & 22.2 & 24.3 & 38.61 & 32.2 & 46.9 & 40.8 & 25.2 \\
\hline \multirow[t]{2}{*}{11} & 0.4 & 0.0 & 0.0 & 0.0 & 0.0 & 0.1 & 0.1 \\
\hline & 30.6 & 0.0 & 0.0 & 0.0 & 23.4 & 28.3 & 31.0 \\
\hline \multirow[t]{2}{*}{12} & 0.8 & 0.8 & 0.75 & 0.7 & 1.0 & 1.0 & 1.1 \\
\hline & 15.0 & 15.4 & 12.34 & 11.3 & 3.4 & 5.2 & 5.9 \\
\hline \multirow[t]{2}{*}{13} & 0.8 & 0.8 & 0.85 & 0.9 & 1.0 & 1.0 & 1.1 \\
\hline & 10.2 & 18.5 & 11.25 & 9.5 & 5.7 & 5.2 & 8.1 \\
\hline \multirow[t]{2}{*}{14} & 0.5 & 0.4 & 0.37 & 0.3 & 0.6 & 0.6 & 0.6 \\
\hline & 16.1 & 12.3 & 18.42 & 14.2 & 9.3 & 8.9 & 0.0 \\
\hline \multirow[t]{2}{*}{15} & 0.8 & 0.8 & 0.75 & 0.8 & 1.0 & 1.0 & 1.0 \\
\hline & 7.2 & 9.4 & 9.40 & 8.4 & 4.7 & 9.0 & 6.4 \\
\hline \multirow[t]{2}{*}{16} & 0.5 & 0.4 & 0.31 & 0.3 & 0.5 & 0.6 & 0.6 \\
\hline & 11.9 & 11.5 & 9.72 & 9.3 & 7.0 & 8.6 & 7.2 \\
\hline \multirow[t]{2}{*}{17} & 0.8 & 0.8 & 0.78 & 0.72 & 0.7 & 0.5 & 0.6 \\
\hline & 16.7 & 4.9 & 4.95 & 5.2 & 16.3 & 13.7 & 6.3 \\
\hline \multirow[t]{2}{*}{18} & 0.7 & 0.7 & 0.67 & 0.7 & 0.6 & 0.5 & 0.6 \\
\hline & 11.6 & 7.5 & 7.50 & 5.6 & 12.6 & 8.9 & 4.1 \\
\hline \multirow[t]{2}{*}{19} & 1.1 & 1.2 & 1.24 & 1.3 & 1.1 & 1.0 & 1.0 \\
\hline & 12.0 & 4.8 & 4.35 & 5.8 & 14.0 & 13.0 & 5.1 \\
\hline \multirow[t]{2}{*}{20} & 0.4 & 0.2 & 0.34 & 0.4 & 0.4 & 0.3 & 0.4 \\
\hline & 12.5 & 6.8 & 17.62 & 13.3 & 12.1 & 10.9 & 5.1 \\
\hline
\end{tabular}


Tab. 2. - continued

\begin{tabular}{rrrlrrrr}
\hline & \multicolumn{7}{c}{ Populations } \\
\hline \multirow{2}{*}{21} & 103 & 214 & 217 & 221 & \multicolumn{1}{c}{201} & \multicolumn{1}{c}{32} & 104 \\
\hline \multirow{2}{*}{23} & 0.9 & 0.8 & 0.84 & 0.9 & 0.8 & 0.6 & 0.7 \\
& 13.3 & 7.5 & 7.5 & 8.4 & 12.8 & 10.9 & 5.0 \\
& 0.9 & 0.8 & 0.78 & 0.8 & 0.7 & 0.6 & 0.6 \\
& 13.3 & 8.4 & 8.44 & 5.5 & 11.6 & 8.0 & 0.0 \\
& 1.0 & 1.3 & 1.36 & 1.1 & 1.2 & 1.0 & 1.2 \\
& 10.9 & 7.3 & 7.36 & 6.8 & 8.7 & 13.0 & 5.1 \\
& 0.6 & 41.2 & 34.29 & 30.1 & 0.4 & 0.4 & 0.4 \\
& 9.8 & 36.9 & 28.39 & 37.2 & 8.4 & 12.1 & 8.4 \\
\hline
\end{tabular}

Tab. 3. Mean (first line) and coefficient of variation in \% (second line) of Dysphania botrys populations for each of the 24 observed characters

\begin{tabular}{rrrrrrrrrrrrr}
\hline & & & & & \multicolumn{1}{c}{ Populations } & & & & & & \\
& 29 & 97 & 100 & 35 & 102 & 99 & 98 & 101 & 53 & 30 & 34 & 45 \\
\hline 1 & 44.3 & 51.4 & 48.2 & 46.0 & 51.7 & 40.6 & 52.4 & 59.3 & 43.9 & 45.5 & 47.9 & 24.7 \\
& 24.3 & 25.2 & 17.5 & 20.2 & 20.8 & 40.2 & 12.4 & 16.1 & 27.5 & 27.6 & 14.4 & 44.2 \\
2 & 2.4 & 3.7 & 4.0 & 2.2 & 3.3 & 3.7 & 4.3 & 3.1 & 3.3 & 2.1 & 3.0 & 2.9 \\
& 30.4 & 38.5 & 40.3 & 12.9 & 41.4 & 34.1 & 28.8 & 28.2 & 40.6 & 24.4 & 47.9 & 46.0 \\
3 & 1.4 & 1.6 & 0.9 & 0.9 & 1.4 & 1.7 & 2.0 & 1.5 & 1.7 & 1.2 & 1.6 & 1.4 \\
& 26.5 & 44.6 & 19.4 & 19.8 & 39.7 & 44.6 & 27.5 & 26.8 & 40.8 & 24.4 & 41.8 & 43.0 \\
4 & 2.3 & 2.5 & 4.7 & 3.2 & 2.4 & 2.4 & 2.2 & 2.1 & 1.9 & 1.6 & 1.8 & 2.2 \\
& 35.4 & 31.7 & 29.2 & 39.7 & 32.5 & 21.3 & 27.5 & 26.2 & 24.1 & 22.6 & 20.3 & 15.1 \\
5 & 1.1 & 1.2 & 1.5 & 1.5 & 1.2 & 0.6 & 1.2 & 1.3 & 1.4 & 1.4 & 1.3 & 0.6 \\
& 37.3 & 26.8 & 17.5 & 17.5 & 37.4 & 32.5 & 20.9 & 26.5 & 28.4 & 23.1 & 19.6 & 32.2 \\
6 & 0.8 & 0.8 & 0.7 & 0.7 & 0.8 & 0.6 & 0.8 & 0.7 & 0.7 & 0.7 & 0.7 & 0.6 \\
& 26.1 & 29.4 & 12.8 & 11.7 & 28.7 & 27.1 & 12.9 & 17.0 & 11.7 & 16.0 & 14.6 & 31.5 \\
7 & 0.3 & 0.3 & 0.4 & 0.3 & 0.4 & 0.4 & 0.3 & 0.3 & 0.3 & 0.3 & 0.3 & 0.3 \\
& 18.2 & 30.8 & 14.4 & 11.4 & 23.0 & 24.1 & 11.0 & 26.5 & 22.9 & 21.9 & 16.5 & 39.0 \\
8 & 2.7 & 2.7 & 2.0 & 2.2 & 2.3 & 1.8 & 2.4 & 2.7 & 2.5 & 2.7 & 2.6 & 2.1 \\
& 39.2 & 40.2 & 19.6 & 10.9 & 38.5 & 22.5 & 16.6 & 18.3 & 17.7 & 17.2 & 24.6 & 23.9 \\
9 & 0.9 & 0.4 & 0.0 & 0.0 & 0.1 & 0.4 & 0.2 & 0.1 & 0.5 & 0.1 & 0.9 & 0.4 \\
& 29.5 & 45.8 & 39.3 & 40.4 & 49.5 & 47.8 & 46.6 & 55.1 & 11.3 & 46.3 & 49.6 & 47.0 \\
10 & 25.6 & 25.4 & 24.9 & 24.9 & 25.6 & 19.0 & 40.5 & 46.7 & 34.5 & 25.6 & 40.2 & 19.7 \\
& 34.7 & 35.3 & 18.9 & 56.6 & 34.7 & 35.8 & 16.6 & 8.8 & 30.6 & 34.7 & 17.0 & 38.7 \\
11 & 0.2 & 0.7 & 0.2 & 0.2 & 0.2 & 0.3 & 0.7 & 0.2 & 0.7 & 0.2 & 0.3 & 0.3 \\
& 40.1 & 43.3 & 51.6 & 51.6 & 34.5 & 15.8 & 43.2 & 45.9 & 43.2 & 43.0 & 35.6 & 15.6 \\
12 & 0.9 & 0.9 & 1.1 & 1.1 & 0.9 & 0.9 & 1.0 & 1.0 & 1.1 & 1.0 & 1.0 & 0.9 \\
& 8.6 & 8.6 & 4.9 & 4.9 & 8.5 & 9.7 & 4.8 & 4.9 & 5.0 & 4.8 & 4.8 & 9.5 \\
13 & 0.9 & 0.9 & 1.1 & 1.1 & 0.9 & 0.9 & 0.8 & 0.8 & 0.7 & 0.8 & 0.8 & 0.8 \\
& 12.0 & 10.4 & 7.2 & 7.2 & 11.5 & 14.9 & 6.8 & 10.2 & 6.7 & 14.3 & 6.8 & 13.8 \\
& 0.3 & 0.4 & 0.4 & 0.3 & 0.4 & 0.3 & 0.3 & 0.3 & 0.4 & 0.3 & 0.3 & 0.3 \\
& 12.7 & 15.8 & 16.4 & 14.1 & 17.3 & 16.6 & 14.1 & 9.8 & 14.5 & 10.5 & 13.8 & 13.3 \\
\hline \multirow{4}{*}{50}
\end{tabular}


Grozeva N. H., Cvetanova Y. G.

Tab. 3. - continued

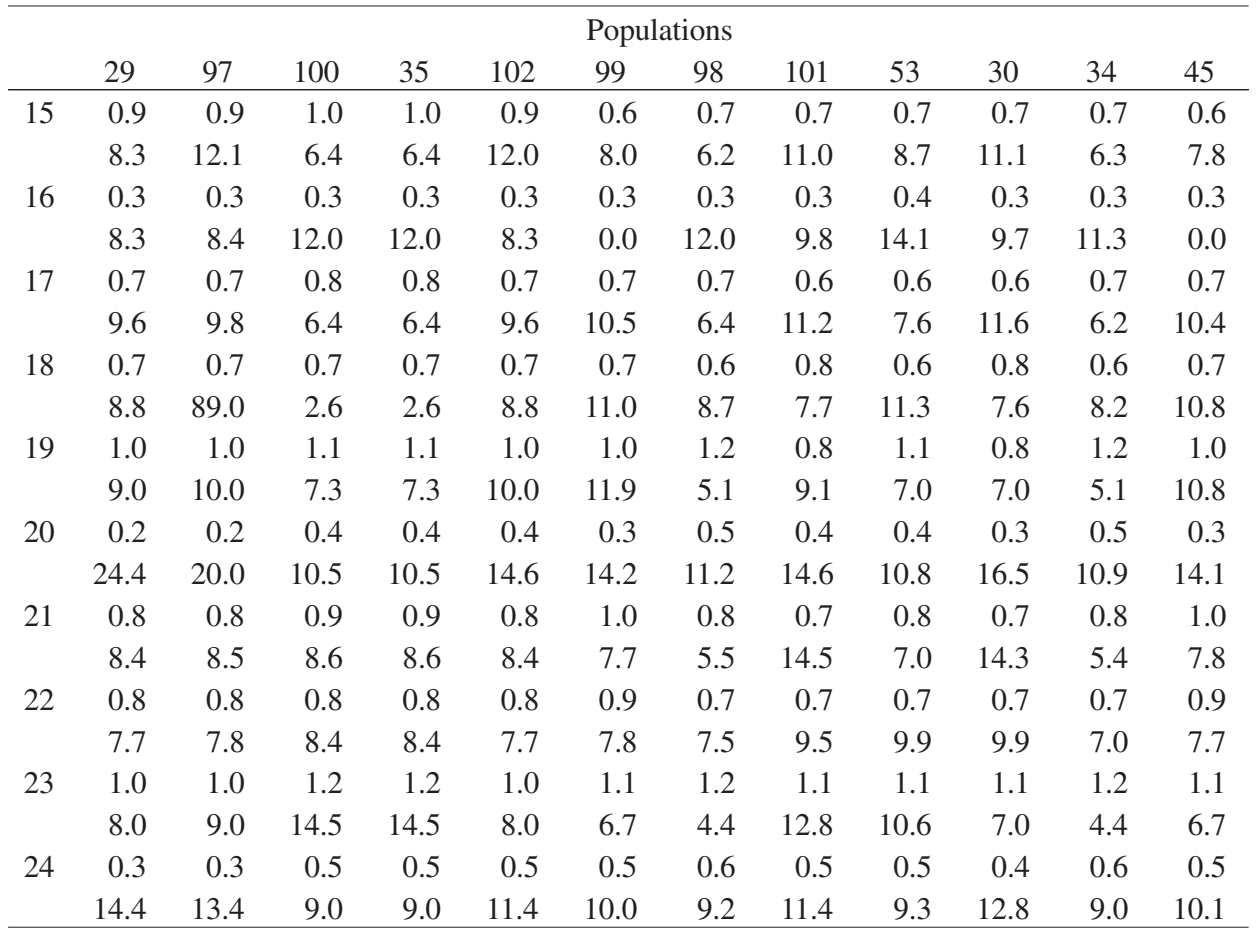

Tab. 4. Mean (first line) and coefficient of variation in \% (second line) of Dysphania multifida populations for each of the 24 observed characters

\begin{tabular}{|c|c|c|c|c|c|c|c|}
\hline & \multicolumn{7}{|c|}{ Populations } \\
\hline & 103 & 214 & 217 & 221 & 201 & 32 & 104 \\
\hline \multirow[t]{2}{*}{1} & 51.2 & 90.9 & 73.4 & 88.6 & 83.6 & 54.2 & 65.5 \\
\hline & 21.9 & 15.6 & 30.6 & 24.6 & 24.9 & 29.1 & 32.5 \\
\hline \multirow[t]{2}{*}{2} & 1.3 & 1.3 & 1.4 & 1.6 & 1.4 & 1.2 & 1.2 \\
\hline & 32.9 & 11.9 & 24.7 & 15.2 & 20.8 & 32.1 & 25.7 \\
\hline \multirow[t]{2}{*}{3} & 0.5 & 0.6 & 0.6 & 0.8 & 0.7 & 0.6 & 0.6 \\
\hline & 35.5 & 18.5 & 23.8 & 9.3 & 19.9 & 35.7 & 32.8 \\
\hline \multirow[t]{2}{*}{4} & 2.6 & 2.3 & 2.5 & 1.9 & 2.1 & 2.5 & 2.1 \\
\hline & 39.1 & 23.4 & 26.5 & 20.1 & 21.1 & 51.4 & 44.0 \\
\hline \multirow[t]{2}{*}{5} & 0.4 & 0.4 & 0.4 & 0.5 & 0.4 & 0.2 & 0.4 \\
\hline & 20.9 & 21.1 & 18.7 & 11.7 & 17.0 & 22.6 & 20.7 \\
\hline \multirow[t]{2}{*}{6} & 0.5 & 0.8 & 0.7 & 0.7 & 0.8 & 0.5 & 0.6 \\
\hline & 31.5 & 17.2 & 23.6 & 10.6 & 15.3 & 36.6 & 32.4 \\
\hline \multirow[t]{2}{*}{7} & 0.3 & 0.4 & 0.4 & 0.5 & 0.4 & 0.3 & 0.3 \\
\hline & 35.2 & 20.5 & 17.6 & 11.0 & 17.0 & 21.3 & 37.8 \\
\hline \multirow[t]{2}{*}{8} & 1.9 & 2.3 & 1.8 & 1.6 & 1.8 & 1.9 & 1.9 \\
\hline & 22.2 & 20.4 & 28.8 & 15.1 & 20.2 & 26.3 & 23.9 \\
\hline
\end{tabular}


Tab. 4. - continued

\begin{tabular}{|c|c|c|c|c|c|c|c|}
\hline & \multicolumn{7}{|c|}{ Populations } \\
\hline & 103 & 214 & 217 & 221 & 201 & 32 & 104 \\
\hline \multirow[t]{2}{*}{9} & 0.2 & 0.2 & 0.3 & 0.3 & 0.3 & 0.2 & 0.3 \\
\hline & 19.3 & 20.3 & 19.1 & 20.7 & 22.1 & 29.9 & 22.9 \\
\hline \multirow[t]{2}{*}{10} & 36.9 & 73.1 & 49.3 & 64.6 & 63.3 & 39.6 & 43.9 \\
\hline & 28.8 & 19.8 & 38.8 & 15.8 & 22.9 & 33.5 & 33.0 \\
\hline \multirow[t]{2}{*}{11} & 0.1 & 0.3 & 0.2 & 0.3 & 0.2 & 0.1 & 0.1 \\
\hline & 54.1 & 43.7 & 47.3 & 42.6 & 41.7 & 40.1 & 44.7 \\
\hline \multirow[t]{2}{*}{12} & 1.2 & 1.2 & 1.1 & 1.0 & 1.1 & 1.2 & 1.2 \\
\hline & 4.9 & 16.4 & 14.3 & 10.3 & 10.2 & 8.8 & 9.6 \\
\hline \multirow[t]{2}{*}{13} & 1.0 & 1.0 & 1.0 & 1.1 & 1.1 & 1.0 & 1.0 \\
\hline & 6.6 & 12.6 & 10.6 & 8.4 & 7.8 & 8.9 & 11.4 \\
\hline \multirow[t]{2}{*}{14} & 0.4 & 0.4 & 0.4 & 0.5 & 0.4 & 0.4 & 0.4 \\
\hline & 13.8 & 9.3 & 16.9 & 12.2 & 7.8 & 13.4 & 16.9 \\
\hline \multirow[t]{2}{*}{15} & 0.0 & 0.0 & 0.0 & 0.0 & 0.0 & 0.0 & 0.0 \\
\hline & 0.0 & 0.0 & 0.0 & 0.0 & 0.0 & 0.0 & 0.0 \\
\hline \multirow[t]{2}{*}{16} & 0.0 & 0.0 & 0.0 & 0.0 & 0.0 & 0.0 & 0.0 \\
\hline & 0.0 & 0.0 & 0.0 & 0.0 & 0.0 & 0.0 & 0.0 \\
\hline \multirow[t]{2}{*}{17} & 0.8 & 0.9 & 0.8 & 0.8 & 0.8 & 0.8 & 0.8 \\
\hline & 7.2 & 4.3 & 7.8 & 8.1 & 7.8 & 5.9 & 7.3 \\
\hline \multirow[t]{2}{*}{18} & 0.8 & 0.8 & 0.8 & 0.9 & 0.8 & 0.8 & 0.8 \\
\hline & 8.2 & 5.4 & 6.6 & 6.0 & 5.6 & 8.9 & 7.7 \\
\hline \multirow[t]{2}{*}{19} & 1.1 & 1.1 & 1.1 & 0.9 & 1.0 & 1.1 & 1.0 \\
\hline & 8.5 & 7.6 & 6.5 & 11.1 & 11.0 & 5.2 & 8.7 \\
\hline \multirow[t]{2}{*}{20} & 0.3 & 0.3 & 0.3 & 0.4 & 0.3 & 0.3 & 0.3 \\
\hline & 18.9 & 0.0 & 16.0 & 14.7 & 14.6 & 20.9 & 13.2 \\
\hline \multirow[t]{2}{*}{21} & 0.9 & 1.0 & 0.9 & 1.0 & 1.0 & 0.9 & 0.9 \\
\hline & 6.4 & 5.3 & 7.1 & 6.5 & 4.6 & 5.8 & 6.4 \\
\hline \multirow[t]{2}{*}{22} & 0.9 & 0.9 & 0.9 & 0.9 & 0.9 & 0.9 & 0.9 \\
\hline & 7.2 & 0.0 & 8.1 & 8.9 & 8.1 & 7.6 & 8.3 \\
\hline \multirow[t]{2}{*}{23} & 1.1 & 1.0 & 1.1 & 1.1 & 1.1 & 1.0 & 1.0 \\
\hline & 7.5 & 8.0 & 5.7 & 8.9 & 10.0 & 9.6 & 6.7 \\
\hline \multirow[t]{2}{*}{24} & 0.4 & 0.4 & 0.4 & 0.4 & 0.4 & 0.4 & 0.4 \\
\hline & 7.8 & 0.0 & 7.8 & 0.0 & 0.0 & 15.6 & 5.2 \\
\hline
\end{tabular}

The results of the ANOVA (Tab. 5) demonstrate that in all species, interpopulation variability is dominant in total variability.

The interpopulation variation was evaluated in Dysphania botrys, D. pumilio, D. ambrosioides and $D$. multifida, as $D$. schraderiana was investigated in a single population. The values of Euclidean distances (Ed) varied within different limits in the individual taxa (Tabs. 6-9)

The UPGA cluster analysis based on the morphological pairwise similarities (Euclidean distances between population centroids) enabled us to detect two main clusters A and B 
Grozeva N. H., Cvetanova Y. G.

Tab. 5. Percentage of the interpopulation variation in the overall morphological variation for each character in Dysphania

\begin{tabular}{ccccc}
\hline \multirow{2}{*}{ Character № } & \multicolumn{4}{c}{ Species } \\
& D. botrys & D. pumilio & D. ambrosioides & D. multifida \\
\hline 1 & 37.7 & 30.1 & 66.0 & 43.2 \\
2 & 29.2 & 45.7 & 47.7 & 29.2 \\
3 & 65.1 & 47.6 & 43.4 & 64.5 \\
4 & 46.4 & 70.9 & 38.1 & 49.9 \\
5 & 69.1 & 32.2 & 48.0 & 61.1 \\
6 & 61.8 & 51.3 & 31.1 & 37.0 \\
7 & 66.5 & 46.1 & 68.0 & 53.9 \\
8 & 67.7 & 55.8 & 40.2 & 57.3 \\
9 & 45.1 & 66.3 & 74.6 & 57.9 \\
10 & 76.6 & 65.3 & 71.1 & 48.7 \\
11 & 69.3 & 0.0 & 59.4 & 50.6 \\
12 & 52.1 & 55.7 & 62.3 & 55.7 \\
13 & 66.5 & 50.9 & 62.9 & 52.9 \\
14 & 55.7 & 59.0 & 64.9 & 38.2 \\
15 & 78.9 & 52.7 & 55.7 & 0.0 \\
16 & 33.1 & 56.8 & 59.9 & 0.0 \\
17 & 41.6 & 59.5 & 85.1 & 61.4 \\
18 & 57.0 & 56.2 & 94.0 & 63.0 \\
19 & 57.0 & 49.3 & 65.1 & 52.4 \\
20 & 76.8 & 52.8 & 78.7 & 61.5 \\
21 & 52.5 & 54.9 & 91.5 & 58.7 \\
22 & 66.4 & 52.2 & 91.6 & 55.2 \\
23 & 64.0 & 50.1 & 56.6 & 68.4 \\
24 & 61.7 & 50.6 & 0.0 & 52.1 \\
\hline
\end{tabular}

Tab. 6. Values of Euclidean distances between the pairs of populations of $D$. pumilio based on 24 characters.

\begin{tabular}{crc}
\hline $\begin{array}{l}\text { Number of } \\
\text { population }\end{array}$ & 214 & 217 \\
\hline 217 & 54 & \\
221 & 111 & 57 \\
\hline
\end{tabular}

Tab. 7. Values of Euclidean distances between pairs of populations of $D$. ambrosioides based on 24 characters.

\begin{tabular}{ccc}
\hline $\begin{array}{c}\text { Number of } \\
\text { population }\end{array}$ & 32 & 104 \\
\hline 104 & 125 & \\
201 & 295 & 194 \\
\hline
\end{tabular}

(Fig. 1). Cluster A consists of two subclusters $A_{1}$ and $A_{2}$. The populations of Dysphania multifida form the subcluster $\mathrm{A}_{1}$, while the populations of $D$. botrys, $D$. pumilio and $D$. schraderiana were grouped by their own species in the subcluster $\mathrm{A}_{2}$. Cluster B contains the populations of D. ambrosioides. 
Tab. 8. Values of Euclidean distances between the pairs of populations within Dysphania multifida based on 24 characters

\begin{tabular}{crrrrrr}
\hline $\begin{array}{c}\text { Number of } \\
\text { population }\end{array}$ & 39 & 40 & 105 & 106 & 107 & 108 \\
\hline 40 & 537 & & & & & \\
105 & 254 & 296 & & & & \\
106 & 465 & 122 & 216 & & & \\
107 & 418 & 89 & 173 & 51 & & \\
108 & 40 & 497 & 215 & 425 & 378 & \\
109 & 158 & 388 & 96 & 310 & 266 & 121 \\
\hline
\end{tabular}

Tab. 9. Values of Euclidean distances between the pairs of populations of Dysphania botrys based on 24 characters

\begin{tabular}{crrrrrrrrrrr}
\hline $\begin{array}{c}\text { Number of } \\
\text { Population }\end{array}$ & 29 & 97 & 100 & 35 & 102 & 99 & 98 & 101 & 53 & 30 & 34 \\
\hline 97 & 72 & & & & & & & & & & \\
100 & 43 & 34 & & & & & & & & & \\
35 & 22 & 59 & 31 & & & & & & & & \\
102 & 74 & 5 & 37 & 60 & & & & & & & \\
99 & 77 & 126 & 97 & 83 & 129 & & & & & & \\
98 & 171 & 152 & 162 & 171 & 150 & 245 & & & & & \\
101 & 296 & 265 & 273 & 283 & 266 & 267 & 410 & & & & \\
53 & 90 & 119 & 106 & 100 & 119 & 158 & 105 & 378 & & & \\
30 & 13 & 62 & 34 & 15 & 63 & 84 & 166 & 290 & 92 & & \\
34 & 151 & 152 & 153 & 155 & 151 & 224 & 47 & 417 & 69 & 148 & \\
45 & 205 & 274 & 241 & 220 & 276 & 160 & 347 & 398 & 243 & 216 & 309 \\
\hline
\end{tabular}

The results from the SDA are presented in table 10. The first three discriminant (canonical) functions account for over $98 \%$ of the total variance. Overall, the discrimination between species is highly significant (Wilks' Lambda $=0.00026, \mathrm{~F}=567.01, \mathrm{p}<0.001$ ). Wilks' Lambda is the standard statistic that has been used to denote the statistical significance of the discriminatory power of the current model. The closer to 0 the Wilks' Lambda, the greater is the contribution of the model to the overall discrimination. The Partial Wilks' Lambda values in the first column (Tab. 10) present the unique contribution of each character in the model to the discrimination between species. The lower the value in this column, the greater is the unique discriminatory power of the respective character. All discriminant functions and variables in the model were highly significant $(\mathrm{p}<0.001)$

The standardized discriminant function coefficients determine the unique contribution of each character to the discriminant functions D1-D3. The first discriminant function which provides the most overall discrimination between the five species is loaded most heavily by the width and the length of perianth lobes in the female flower, and the length of perianth lobes in the bisexual flower. The second discriminant function seems to be marked 


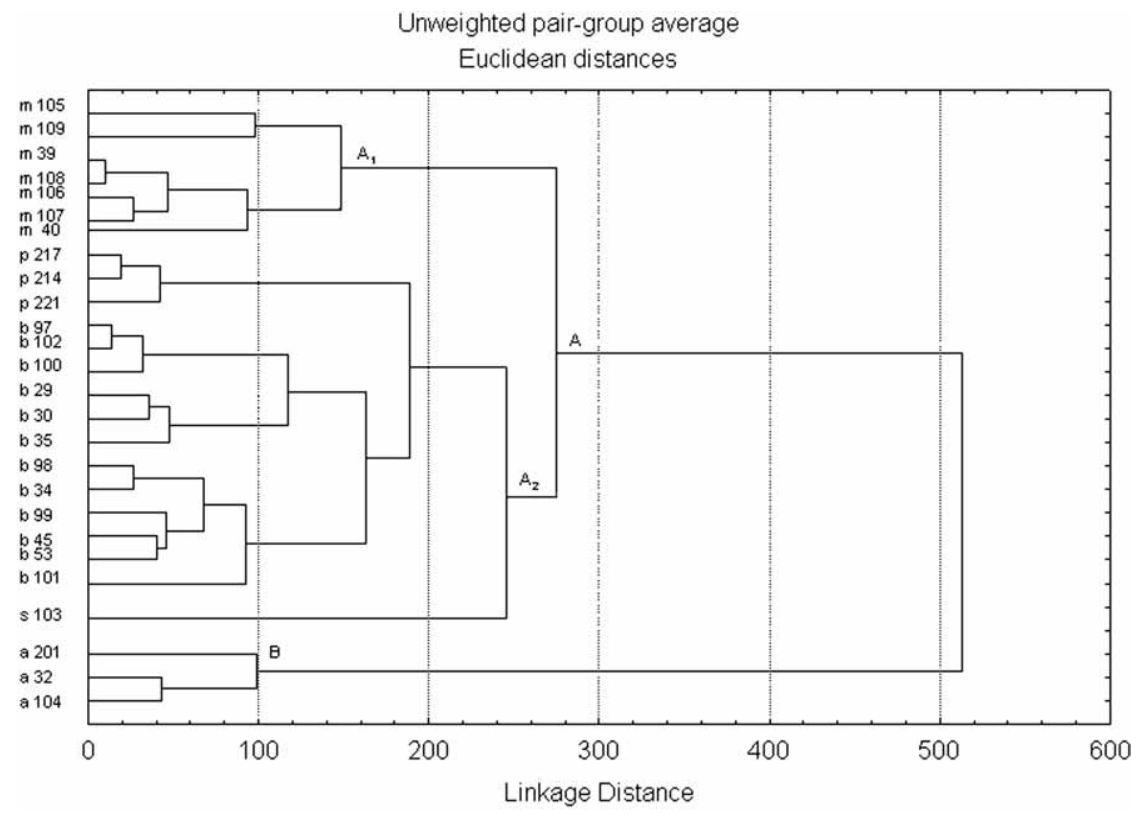

Fig. 1. Dendrogram of the cluster analysis of the genus Dysphania: № $105-40=D$. multifida (m); № $217-221=D$. pumilio $(\mathrm{p})$; № 97-101 $=$ D. botrys $(\mathrm{b})$; № $103=D$. schraderiana (s); № $201-104=$ D. ambrosioides (a)

Tab. 10. The sequence of the ten most significant characters for discrimination between five species of genus Dysphania obtained by SDA and corresponding values of Partial Wilks' Lambda, F-values and standardized coefficients for discriminant functions $D_{1}-D_{3}$. The eigenvalues, cumulative percentage of the variance explained by the first three roots are presented in the bottom two rows.

\begin{tabular}{|c|c|c|c|c|c|}
\hline Characters & F-remove & $\begin{array}{l}\text { Wilks' } \\
\text { Lambda }\end{array}$ & $\mathrm{D}_{1}$ & $\mathrm{D}_{2}$ & $\mathrm{D}_{3}$ \\
\hline $\begin{array}{l}\mathrm{x}_{16} \text {. Width of perianth lobes in } \\
\text { female flower }\end{array}$ & 307.0124 & 0.000674 & -0.75486 & -0.096454 & -0.255158 \\
\hline$x_{7}$. Width of upper leaf & 169.4663 & 0.000488 & -0.03937 & -0.384323 & 0.715588 \\
\hline $\mathrm{x}_{6 .}$ Length of upper leaf & 137.8743 & 0.000445 & -0.12250 & -0.666162 & -0.372245 \\
\hline $\begin{array}{l}\mathrm{x}_{15} \text {. Length of perianth lobes in } \\
\text { female flower }\end{array}$ & 137.6188 & 0.000445 & -0.71658 & 0.390183 & 0.069843 \\
\hline $\begin{array}{l}\mathrm{x}_{13} \text {. Length of perianth lobes in } \\
\text { bisexual flower }\end{array}$ & 72.0499 & 0.000356 & 0.47251 & -0.214634 & -0.386907 \\
\hline $\mathrm{x}_{24 .}$ Thickness of fruit & 54.0739 & 0.000332 & -0.15462 & -0.220721 & 0.206799 \\
\hline $\mathrm{x}_{11 .}$ Length of flower petiole & 85.6233 & 0.000374 & -0.01660 & -0.107996 & 0.471146 \\
\hline $\mathrm{x}_{5}$. Length of basal leaf petiole & 62.8143 & 0.000343 & 0.10170 & 0.156215 & 0.544039 \\
\hline $\mathrm{x}_{12 .}$. Diameter of flower & 45.4535 & 0.000320 & 0.28564 & -0.306588 & -0.234661 \\
\hline $\mathrm{x}_{9}$. Llength of upper leaf petiole & 37.9717 & 0.000310 & 0.10216 & -0.273894 & -0.373920 \\
\hline Eigenvalues & & & 41.98092 & 7.680871 & 4.657472 \\
\hline Cumulative Prop. of Variance & & & 0.76118 & 0.900440 & 0.984887 \\
\hline
\end{tabular}




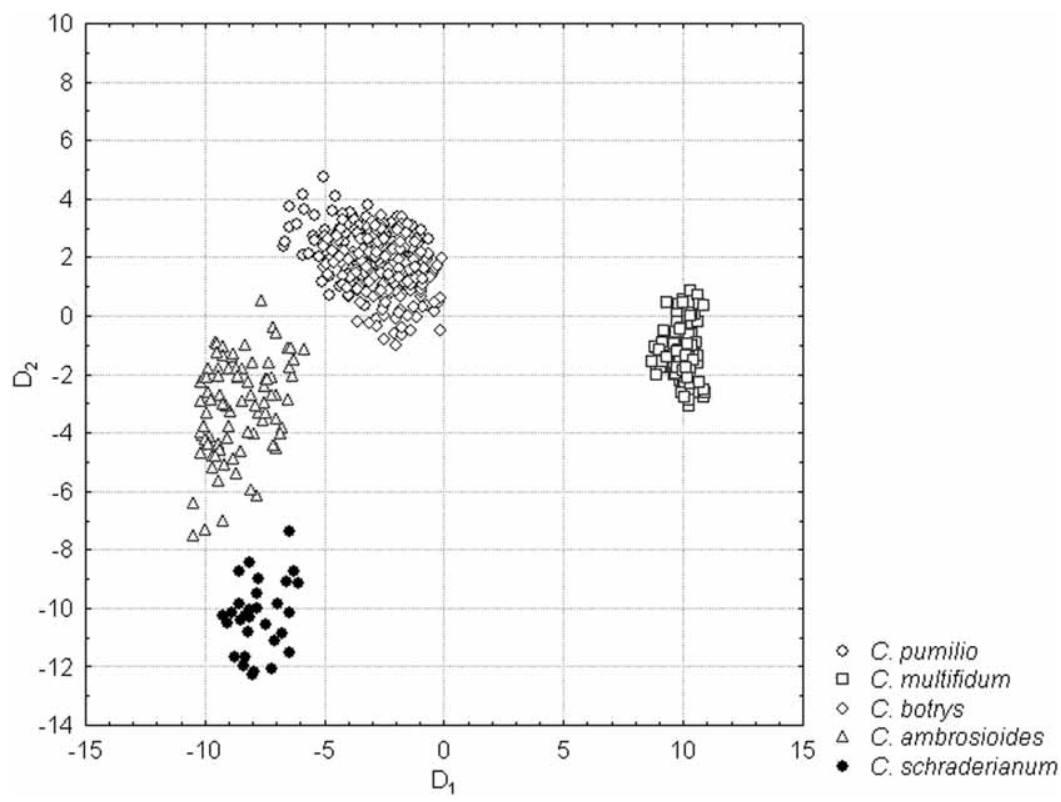

Fig. 2. Scatter plot of scores of the first two canonical roots $D_{1}$ and $D_{2}$ for the individuals of the five Dysphania species

mostly by the length of the upper leaf, while the width of the upper leaf, length of flower petiole and length of basal leaf petiole contribute mostly to the third discriminant function.

The populations of $D$. multifida, D. ambrossoides and D. schraderiana have been classified $100 \%$ correctly on the fourth step of the SDA while the populations of the other two species D. botrys and D. pumilio were classified with $98.46 \%$ and $92.22 \%$ correctness, respectively, on the tenth step.

The scatter plot of the canonical scores of the individuals from the five species on the first two discriminant dimensions (Fig. 2) enabled us to determine the nature of the discrimination for the first two discriminant roots. The first discriminant function mostly discriminates between $D$. multifida and the four other species. Clearly, the populations of $D$. multifida are plotted much further to the right of the central line. The second function seems to provide some discrimination between the species of $D$. ambrosioides, $D$. schraderiana and $D$. multifida (which mostly show negative values for the second canonical function) and the other two species D. botrys and D. pumilio (which have mostly positive values).

\section{Discussion}

The results of the present complete population research of genus Dysphania confirm the data from our previous research (GROZEVA and CVETANOVA 2008, 2011) on the species from family Chenopodiaceae, namely that vegetative traits are more variable than generative ones (Tabs. 2-4). The lamina size of the lower leaves, petiole length of upper or lower leaves and stem height are the most variable traits in almost all populations. The characteristics of the seed dimensions (i.e., length, width and ratio between them) are some of the most con- 
servative traits. No variability has been recorded for the trait length of female flower perianth in two of the populations of D. botrys, No. 45 from Tselina and No. 99 from Troyan. The high variability of stem height and leaf characters of the species from Chenopodium senso lato, and the lack of any considerable variability in seed characters have been acknowledged by researchers of the genus from various parts of the world (KowAL 1953, ENGSTRAND and Gustafsson 1972-1974, ReYNOLDS and CRAUfORD 1980, BASSET and Crompton 1982, DostáleK et al. 1990, Al-Turki and GHAFOOR 1996, Uotila 2001).

The main source of phenotype variation in all species is the interpopulation variation. The interpopulation differences were fewer and varied within much narrower limits in $D$. pumilio (Tab. 6). That is associated with the small differences between population habitats (Tab. 1) as well as with the lack of karyotype variability. Low variability level has been found among the populations of $D$. ambrosioides (Tab. 7), which relates to their similar habitats (sandy terrains in close proximity to a water basin) and similar altitudes (28-164 m). The recorded higher variability for the population from the Danubian plain than in the two populations from the Thracian lowland could be explained by either the differences in the soil and climatic conditions due to their geographic remoteness or the established karyotype differences.

Large interpopulation morphological variation was observed in D. multifida (Tab. 8) and the greatest differences have been recorded among populations with different karyotypes. Among populations with the same structure of the karyotypes, strong morphological similarity was recorded between populations with similar community components - No. 39 from the island of Golyama Barzina and No. 108 from Parvomay $(\mathrm{Ed}=40)$, where $D$. multifida dominates and cereal species are quite limited; No. 106 from Ihtiman and No. 107 from Ivaylovgrad $(\mathrm{Ed}=51)$, where cereal species are dominant. According to our observations, the established relationship is directly linked to the biological characteristics of the species. D. multifida is a perennial grass plant with a shallow root system and highly branched creeping stems. Its normal vegetative development needs space and efficient amount of water and food supplies in the topsoil, and these depend on the composition of the population and the existing relationships within it.

The largest interpopulation morphological variation was observed in Dysphania botrys (Tab. 9) which is in agreement with the diversity of ecological conditions, altitudes (0-748 $\mathrm{m}$ ), ecosystems (Tab. 1), as well as the constituted kariotype differences. The interpopulation differences within this species were the least between populations No. 97 from Pomorie, No. 102 from »Sinite kamani « Natural Park $(E d=5)$, and population No. 29 from the Varna lake and population No. 30 from Plovdiv $(\mathrm{Ed}=13)$, which have identical karyotype structures. High morphological similarity was found between population No. 35 from Belene and population No. 30 from Plovdiv $(\mathrm{Ed}=15)$, and population No. 29 from Varna Lake $(E d=22)$, which are with different karyotypes, although they have similar ecological conditions (altitudes up to $200 \mathrm{~m}$, flat terrain, close to a water basin with moist and sandy soil). Of all studied populations, the greatest differences are those from Tselina (population № 45) and Blagoevgrad (population № 101) where the species is a weed in a cultivated community. This is related to better soil conditions (i.e., food substances, moisture, and aeration), and weaker competition between the cultivated and weed plant than in the species' natural habitat. Regardless of the similar composition of communities, both populations differ significantly from each otehr, which relates to their appurtenance to two different and quite distant floristic regions and to the differences found in their karyotypes. 
The interpopulation variability is dominant within the total variability in all species (Tab. 5), which is due mainly to differences in ecological conditions and especially in the various plant communities to which they belong, as for the populations of $D$. ambrosioides, $D$. botrys and $D$. multifida karyological variability is also a factor. The less pronounced intrapopulation variability relates to the smaller number and area of the population, and the uniform ecological conditions within its borders.

After comparing all populations of the species in the genus according to the entire morphological set of quantitative traits (Fig. 1), the greatest similarity was found between the two diploid species $D$. botrys and $D$. pumilio. Quite similar to these two is the third diploid species $-D$. schraderiana. The three species also have similar ecological preferences. A certain morphological similarity was registered between the tetraploid D. multifida and the three diploid species, as well as between the tetraploid $D$. ambrosioides and all other species in the genus. Such morphological similarity among the five species was also noted by UotILA (2001) in Flora Nordica.

In spite of the high morphological similarity among the species, each one of them could be recognized correctly by certain characteristics (Fig. 2). The top ten significant features for differentiation of species, found by SDA were: width of perianth lobes in female flower, width of upper leaf, length of upper leaf, length of perianth lobes in female flower, length of perianth lobes in bisexual flower, thickness of fruit, length of flower petiole, length of basal leaf petiole, diameter of flower, length of upper leaf petiole (Tab. 10). The distinction between D. multifida, D. ambrosioides and D. schraderiana is based on differences in the quantitative traits, while such discrimination between $D$. botrys and $D$. pumilio is not always feasible. Due to the similarity in the greater part of the qualitative traits of these two species, qualitative characteristics should be used as well for their clear-cut distinction. D. pumilio could be distinguished easily from $D$. botrys as well as from the other species of the genus by its 4-5 pale green perianth leaves that harden and whiten at the fruit, as well as by reddish-brown to brown-black seeds with an imperceptible blunt edge. D. botrys was characterized by 5 yellowish-green perianth leaves that do not fully cover the fruit and do not harden and greyish-black seeds with an edge longitudinally split up in two. D. schraderiana differed by 4-5 perianth lobes with clearly defined serrated dorsal edge and black seeds with blunt edge. D. ambrosioides is easily recognizable by its five pale green perianth lobes with clearly defined non-serrated dorsal edge, connate up to $1 / 2$ of their length and brown seeds with blunt edge. D. multifida differed to the greatest degree from the other species with its five heavily furrowed perianth lobes, with no dorsal edge, connate along their entire length, that are preserved at the fruit and form a false pod and dark brown round seeds. Each species could also be identified by its typical indentation of the leaf lamina, however, that is not always a sure method since it is necessary to collect a greater number of whole plants in order to trace the lamina changeability of the lower, middle, and upper leaves.

The data from the present study confirm that polyploidy and diploidy are basic evolutionary mechanisms in genus Dysphania. In tracing the morphological variability, the tendency, known for Chenopodium senso lato, to reduce the sizes of the generative organs and the number of perianth lobes was established. The reduced size of perianth lobes and the decrease in their number facilitate anemophilous pollination. The retention of the perianth lobes at the fruit and the presence of glands on their surface is an adaptation to exozoochory. The nuts stick to animal fur and are carried as they move around, while the reduced size of 
the seeds favours their transportation at greater distances. Perianth lobes in some species have additional features securing reliable attachment: rough surface in $D$. multifida, pointed dorsal edge in D. ambrosioides, serrated dorsal edge in D. schraderiana). The lack of a dorsal edge on the perianth lobes of $D$. botrys and $D$. pumilio is perfectly compensated for by there being more glands on the entire surface of the first species, and on the upper parts of the second.

\section{Acknowledgements}

This study was supported by the Project Scientific Research Fund of Trakya University, Agriculture faculty (Project 2P/08). The authors are grateful to the anonymous reviewers for the valuable comments and suggestions.

\section{References}

Aellen, P., 1960: Chenopodium L. In: ReICHINGer, K. H., Hegis Illustrierte Flora von Mitteleuropa, 3.2., 569-664. Carl Hanser Verlag, Berlin - Hamburg.

Al-Turki, T. A., Ghafoor, A. 1996: The genus Chenopodium L. in Saudi Arabia. Feddes Repertorium 107, 189-208.

Al-Turki, T. A., Mehmood, S. F., Filfilan, S. A., 1999: IOPB chromosome data 15. Newsletter of International Organization of Plant Biosystematists (Pruhonice) 31, 10.

Al-Turki, T. A., Filfilan, S. A., Mehmood, S. F., 2000: A cytological study of flowering plants from Saudi Arabia. Willdenowia 30, 339-358.

Assyov, B., Petrova, A. (eds), 2006: Conspectus of the Bulgarian vascular flora. Distribution maps and floristic elements, 3 (In Bulgarian). BBF, Sofia.

Basset, I., Crompton, C., 1971: Reports. In: LÖVE, Å. (ed.), Chromosome number reports 34. Taxon 20, 785-797.

Basset, I. J., CRompton, C. W., 1982: The genus Chenopodium in Canada. Canadian Journal of Botany 60, 586-610.

Clements, S. E., Mosyakin, S. I., 2003: Dysphania R. Br. In: Editorial Committee (eds), Flora of North America north of Mexico, 4: Magnoliophyta: Caryophyllidae, 1, 267299. Oxford University Press, New York.

DostáleK, J. 1985: Determination of Chenopodium species of flora Czechoslovakia (in Czech). Zprávy České Botanické Společnosti 20, 161-177.

Dostálek, J., HejnỲ, S., HusÁk, Š., SchwarzovÁ, T., DvořÁK, F., 1990: Chenopodium L. In: HejnỲ, S., Slavík, B. (eds), Flora of the Czech Republic, 2 (in Czech), 223-265. Academia, Prague.

DVoŘÁK, F., 1989: Chromosome counts and chromosome morphology of some selected species. Scripta Facultatis Scientiarum Naturalium Universitatis Purkyn 19, 301-322.

DVOŘÁK, F., GRŰLl, F., KURKA, R., RŮŽIČKA, I., DADAKOVÁ, B., 1980: Reports. In: LÖVE, Á. (ed.), Chromosome number reports 68. Taxon 29, 533-547.

Engstrand, L., Gustafsson, M. 1972-1974: Drawings of Scandinavian plants. Chenopodium. Botaniska Notiser 125, 283-286; 126, 1-6, 135-141, 273-276, 393-397; 127, 1-6, 159-164, 291-296, 457-463. 
Giusti, L., 1970: Genus Chenopodium in Argentina. 1: Number of chromosomes (in German). Darwiniana 16, 98-105.

Granado, C., Luque, T., Pastor, J., 1988: Chromosome numbers from Spanish flora 551-555 (in Spanish), Lagascalia 15, 133-136.

GrIF, V. G., AGAPova, N., D., 1986: The methods of description of plant karyotypes (in Russian). Botanichesky Zhurnal 71, 550-553.

Grozeva, N., Cvetanova, Y. 2008: Variability among the populations of two Chenopodium genus species. Proceedings 7 Scientific Conference of Ekology and Health, Academic Publishing House of Agrarian University. Plovdiv, 135-140.

Grozeva, N., Cvetanova, Y. 2011: Chenopodium bonus-henricus (Perennial goosefoot) in Bulgaria. I. Population variability. Trakia Journal of Sciences 9, 1-7.

Grozeva, N., 2007: C. pumilio (Chenopodiaceae): a new species to the Bulgarian flora. Phytologia Balcanica 13, 331-334.

JAVOURKOVÁ-JAROLÍMOVÁ, V. 1992: Chenopodium pumilio R. Br. In: MĚsíčEK, J., JAVOURKOVÁ-JAROLÍMOVÁ,, V. List of chromosome numbers of the Czech vascular plants (in Czech), 75. Academia, Prague.

KaWATAni, T., Ohno, T., 1950: Chromosome numbers of genus Chenopodium: I. Chromosome number of Mexican tea (Ch. ambrosioides), American wormseed (Ch. ambrosioides L. var. altherminticum A Gray) and some allied species. Japanese Journal of Genetics $25,177-180$.

Kawatani, T., Ohno T., 1956: Chromosome numbers of genus Chenopodium. 2. Japanese Journal of Genetics 31, 15-17.

KeEner, C. 1970: Documented plant chromosome numbers 70. Sida Contributions to Botany 3, 533-536.

Khatoon, S., Ali S, I., 1993: Chromosome atlas of the angiosperms of Pakistan. Department of Botany, University of Karachi, Karachi.

KJELlmark, S., 1934: Some new chromosome numbers interpreted species (in German). Botaniska Notiser 117, 389-396.

KowAL, T. 1953: A key for the determination of the seeds of the genera Chenopodium and Atriplex (in Polish). Monographiae Botanicae 1, 87-163.

KÜHN, U. 1993: Chenopodiaceae. In: KuBITZKI, K. (ed.), The families and genera of vascular plants, 2, 253-281. Springer, Hamburg.

Lomonosova, M. N., S. A. Krasnikova, S. A., Krasnikov, A. A., Ebel, A. L., Rudaja, N. A., 2003: Chromosome numbers of the family members Chenopodiaceae representatives from Mongolia and Kazakhstan. Botanichesky Zhurnal 88, 113-115.

LoRZ, A., 1937: Cytological investigations on five Chenopodiaceous genera with special emphasis on chromosome morphology and somatic doubling in Spinacia. Cytologia 8, 241-276.

MARKova, İ., 1966: Chenopodium L. In: YORDANOV, D. (ed.), Flora of the People's Republic Bulgaria, 3, 527-541 (in Bulgarian). Aedibus Academiae Scientiarum Bulgaricae, Serdicae. 
Markova, M., 1968: Karyological study of Epimedium pubigerum (DC) Morren and Decne and Chenopodium multifidum L. Comptes Rendus de lộAcademie Bulgare des Sciences 21, 51-53.

Mehra, P., Malik, C., 1963: Cytology of some Indian Chenopodiaceae. Caryologia 16, 67-84.

MesíčEK, J., 1992: Chenopodium pumilio R. Br. In: MesíčEK, J., JavourkovÁ-JarolímovÁ, V., List of chromosome numbers of the Czech Vascular Plants (in Czech), 75. Academia, Prague.

Mosyakin, S. L., 1993: An outline of a system for Chenopodium L. (species of Europe, North and Central Asia). Ukrainsky Botanichny Zhurnal 50, 71-77.

Mosyakin, S. L., Clements, S. E., 1996: New infrageneric taxa and combination in Chenopodium L. (Chenopodiaceae). Novon 6, 398-403.

Mosyakin, S. L., Clements, S. E., 2002: New nomenclatural combinations in Dysphania R. Br. (Chenopodiaceae): taxa occurring in North America. Ukrainsky Botanichny Zhurnal 59, 380-385.

Mosyakin, S. L., Clements, S. E., 2008: Further transfers of glandular-pubescent species from Chenopodium subg. Ambrosia to Dysphania (Chenopodiaceae). Journal of the Botanical Research Institute of Texas 2, 425-431.

Mulligan, G., 1961: Chromosome numbers of Canadian weeds, 3. Canadian Journal of Botany 39, 1057-1066.

Murín, A., Ferakova, J. 1974: Chenopodium L. In: Majovsky et al. (eds), Index of chromosome numbers of Slovakian flora, 3. Acta Facultatis Rerum Naturalium Universitatis Comenianae 22, 1-20.

QueIros, M. 1975: Contribution to the cytotaxonomic knowledge of the Spermatophyta in Portugal, 10. Chenopodiaceae (in Portuguese). Boletim da Sociedade Broteriana, Série $2,121-142$.

RAHIMENIJAD, M. R. 2004: Chenopodium pumilio (Chenopodiaceae) new to the flora of Iran. Willdenovia 34, 183-186.

Raghavan, R., Arora, C. 1958: Chromosome numbers in Indian medicinal plants, 2. Proceedings of the Indian Academy of Sciences, Section B 47, 352-358.

Reynolds, J., F., CRAwFord, D. J., 1980: A quantitative study of variation in the Chenopodium atrovirens-desiccatum-pratericola complex. American Journal of Botany 67, 1380-1390.

Sharma, A. K., DeY., 1967: A comprehensive cytotaxonomic study on the family Chenopodiaceae. Journal of Cytology and Genetics 2, 114-127.

Schwarzova, T. 1978a: Reports. In: Löve, Å. (ed.), IOPB chromosome number reports 61 , Taxon 27, 375-392.

Schwarzova, T. 1978b: Chenopodium L. In: Majovsky at al. (eds), Index of chromosome numbers of Slovakian flora (part 6), Acta Facultatis Rerum Naturalium Universitatis Comenianae 26, 1-42.

Schwarzova, T. 1980: Reports. In: Löve, Å. (ed.), IOPB chromosome number report 69. Taxon 29, 728. 
Schwarzova, T. 1986: Chromosome numbers of some species of the genus Chenopodium L. from localities in Czechoslovakia. Acta Facultatis Rerum Naturalium Universitatis Comenianae 33, 37-40.

SchwarzovA, T. 1993: Beitrag zur Karyotaxonomie und Evolution mancher Arten der Gattung Chenopodium L. (Sektion Botryoides und Ambrina). Biologia (Bratislava) 48, 421-427.

Silvestre, S. 1984: Chromosome numbers 353-362, In: Choromosome numbers of Spanish flora (in Spanish), 300-364. Lagascalia 12, 298-303.

Uotila, P. 1973: Chromosome counts on Chenopodium L. from SE Europa and SW Asia. Annales Botanici Fennici 10, 337-340.

Uotila, P. 2001: Chenopodium L. In: Jonsell, B. (ed.), Flora Nordica, 2, 4-31. Bergius Foundation, Stockholm.

Uotila, P., SuOminen, J. 1976: The Chenopodium species in Finland, their occurrence and means of immigration. Annales Botanici Fennici 13, 1-25.

Vladimirov, V., Petrova, A., 2010: Reports 190-203. In: Vladimirov, V., Dane, F., SteVANOvić, V., TAN, K. (eds.), New floristic records in the Balkans, 14. Phytologia Balcanica $16,441-443$.

VladimiRov, V., 2011: Reports 124-130. In: VladimiRov, V., Dane, F., TAN, K. (eds.), New floristic records in the Balkans, 17. Phytologia Balcanica 17, 379-380.

Woroschilov, W. 1942: Review of species of Chenopodium L. from section Ambrina (Spach) Hook (in Russian). Botanichesky Zhurnal 27, 33-47.

Zhu, G., Mosyakin, S. L., Clements, S. E. 2003: Chenopodiaceae: Dysphania R. Br. In: Wu, Z. Y., RAven, P. H., Hong, D. Y. (eds), Flora of China, 5. Ulmaceae through Basellaceae, 376-378. Science Press, Beijing and Missori Botanical Garden Press, St. Louis. 


\title{
Floodplain forest communities along the Mura River (NE Slovenia)
}

\author{
Petra KoŠIR ${ }^{1,2, *}$, ANDraž ČARni ${ }^{1,3}$, AleKSANDER MARINŠEK $^{1}$, Urban ŠIlC $^{1}$ \\ ${ }^{1}$ Jovan Hadži Institute of Biology, Research Centre of the Slovenian Academy of \\ Sciences and Arts, Novi trg 2, SI-1001 Ljubljana, Slovenia \\ ${ }^{2}$ University of Primorska, UP FAMNIT, Glagoljaška 8, SI-6000 Koper, Slovenia \\ ${ }^{3}$ University of Nova Gorica, Nova Gorica, Slovenia
}

\begin{abstract}
Ecological gradients along river banks of the Mura River influence forest species composition. On the basis of 58 relevés of floodplain forests along the Mura River, the classification of vegetation plots was performed with the Pc-Ord program. The diagnostic species combination for three clusters revealed after classification was calculated by fidelity measure (phi-coefficient) and presented in an analytic table. Average Ellenberg inidicator values, stream distances and relative elevations of the relevés were passively projected onto PCA to show ecological relationships among them. Correlations of plant functional type and stream distance gradients were calculated with regression analysis. For the main edifiers response curves to the stream distance gradients were made. The classification of the Mura floodplain forests has revealed three ecologically interpretable vegetation types: Salicetum albae (most humid and nutrient-rich sites), Fraxino-Ulmetum allietosum ursini (ecologically intermediate sites), F.-U. quercetosum robori (the driest and the least nutrient-rich sites). Zonation of vegetation is connected to distance from the closest stream which influences species distribution through ecological gradients of moisture and nutrient. The proportion of therophytes is significantly negatively correlated with the distance from the closest stream and the proportion of neophytes is significantly negatively correlated with distance from the main stream.
\end{abstract}

Key words: Floodplain, gradient, hardwood, neophytes, riparian, vegetation, softwood, zonation, Mura River

Abbreviations: DCS - distance from the closest stream, DMS - distance from the main stream.

\section{Introduction}

Floodplain forests are subject to periodic over/the-bank flooding and cycles of erosion and deposition of nutrient-rich sediment. Well drained and nutrient-rich soils of floodplain

* Corresponding author, e-mail: petrako@zrc-sazu.si

Copyright ${ }^{\circledR} 2013$ by Acta Botanica Croatica, the Faculty of Science, University of Zagreb. All rights reserved. 
forests distinguish these forests from the floodplain swamp forests on stagnant water sites with gleyic soils, which are periodically flooded predominately by ground water. Floodplain forests are characterized by the highest species richness and diversity, density and productivity (Deiller et al. 2001, Mitsch and GosselinK 2000, Schnitzler 1994). They include several microhabitats harbouring numerous plant and invertebrate species unable to survive elsewhere (MACHAR 2001). Therefore floodplain forests, according to the Habitat Directive, belong among the habitats of the greatest importance for nature protection on the European scale.

Historically, natural floodplain forests have been fragmented and heavily impacted by watercourse regulations, timber harvesting and other human activities (KLIMO and HAGER 2001).

Like other large European rivers, the Mura has undergone several hydraulic management phases since the $19^{\text {th }}$ century. These regulation works and other human impacts, such as plantation and felling, have modified the floodplain forest ecosystem. Therefore identification of vegetation types along the Mura River is very difficult, undistinct and has not been done yet. Despite many an intervention into the river and its current, the Mura has still preserved so many natural treasures that it is treated as a nationally important value (GORŠAK and BAKAN 2003).

Flooded forests have already been thoroughly studied in many parts of Europe (MÜLLER 1992, SCHNitZler 1994, VichereK et al. 2000, PAAL et al. 2007, WiLlNER and GrABHERR 2007, KeVEy 2008, KLIMo et al. 2008, PoLDINI et al. 2011) and also in the southeastern part of Europe in the area of large rivers, such as the Sava, Drava and Danube (HoRvat et al. 1974, VuKELIĆ and BARIČEVIĆ 2004, 2005).

Two types of forests have usually been identified in the area of floodplain forests: softwood and hardwood forests. Softwood forests are mainly composed of early successional and light-demanding species such as Salix alba, Salix fragilis, Populus nigra and Populus alba. Hardwood forests are dominated by long-living species, with Fraxinus excelsior/Fraxinus angustifolia, Quercus robur and Ulmus minor/Ulmus laevis. Alluvial hardwood forests are found on flooded but well-drained and fertile soils of large European floodplain (SCHNITZLER 1994)

In Slovenia there were some surveys of vegetation of river banks, about all white willow stands Salicetum albae, along some other rivers, such as the Drava (PETRINEC 1999), Soča (DAKSKOBLER et al. 2004), Krka and Mirna (ŠILC 2003), mostly with a relatively narrow belt of riverine forest vegetation. The Mura River has the best preserved floodplain in Slovenia, but floodplain forests of river banks of the Mura River remain so far unresearched.

The main research questions of the study were:

- Which are the main forest vegetation types on the banks of the Mura River and the main ecological gradients that influence species composition of these forests?

- Despite the big changes in flooding regime and human impact (plantation, cutting down) does zonation of vegetation along the Mura River still exist? Is zonation connected to distance from the main stream of the river (DMS) or distance from the closest stream (DCS)?

- What is the distribution of plant functional types (life forms, plant ecological strategies, origin and residence time status) along stream distance gradient? 


\section{Material and methods}

\section{Study area}

The study took place along the Mura River in the eastern part of Slovenia, on the banks of the Mura River and Holocene terraces. This part of Slovenia has a continental climate: the annual mean precipitation is $800 \mathrm{~mm}$ and annual mean temperature is $9.2{ }^{\circ} \mathrm{C}$.

The study area belongs to the sub-Pannonian region, as we can find some Pannonian features; flooded and swamp forests, some very rare Pannonian elements. Since the area is composed mainly of sandstone, the flora shows a mainly central European floristic character.

The Mura (Mur) river is a Central European river, springing at $1898 \mathrm{~m}$ a.s.l. in the Eastern Alps in Austria. The Mura River is the largest tributary of the Drava river, that is the fourth largest tributary of the Danube River. When reaching Slovenia, the Mura river forms a 34-km long state border line between Austria and Slovenia, flows through Slovenian territory for $29 \mathrm{~km}$ and then becomes a state border again: first between Slovenia and Croatia (33 km), and then between Croatia and Hungary (GLOBEVNIK and Mikoš 2009). In Slovenia it has riverbed in lowland with a small gradient. The level of the Mura River increases in spring because of the melting snow in the high mountains and in autumn because of higher precipitation.

Regulation works on the Mura River started in $19^{\text {th }}$ century. Before regulation, $40 \%$ of water flowed through main channel, but today almost all the water flows in the main channel. There are still some side channels in the forests along the Mura River with connection to the main stream of the Mura. Flood protection dikes were constructed in the 1972-1990 period using a 100 year flood design to protect cultivated areas. The Mura River corridor between the dikes is up to $1 \mathrm{~km}$ wide (GLOBEVNIK and MiKoš 2009). Most of the forests range inside these dikes.

\section{Sampling and measurements}

Vegetation of floodplain forests was investigated according to the standard Central European method (BRAUN-BLANQUET 1964). We made 58 relevés of floodplain forests along the Mura River. All the relevés were made inside levees in the area of periodic floods. We did not include floodplain swamp forests (class Alnetea glutinosae) in our research as they have already been investigated (ACCETTO 1994, NEMESSZEGHY 1986, GlaVAĆ 1975). For each plot, GPS coordinates were collected and later on, distances from main stream of Mura (DMS) and distances from the closest stream (DCS), which may be the main or a side stream, were measured from the map in Arc-Gis program. In 14\% of relevés (8 of 58) DCS value equalled DMS value. This means that in $86 \%$ of the relevés the closest stream was a side stream. We also measured the relative elevation of each plot (elevation relative to average river level) with DMR of the area as it is known that elevation as well as distance from the river affects hydroperiod (flood frequency and duration) and thus influences species distribution and abundance (TURNER et al. 2004).

\section{Data analysis}

58 relevés made on flooded sites of the Mura River were entered into the TURBOvEG (HENNEKENS and SCHAMINÉE 2001) database. 
The numerical classification of vegetation plots, based on their species composition, was performed with PC-ORD 5.0 program (MCCunE and MEFFORD 2005). The data was square root transformed. Euclidean (Pythagorean) distance as the distance measure and Flexible Beta method for group linkage were used. We made several classifications with different numbers of clusters of relevés. We subjectively accepted classification with three clusters being most ecologically sound.

58 relevés are presented in the analytic table. The nomenclature of taxa is according to Flora Europaea (TuTiN et al. 1964-1980). Diagnostic species for the clusters (corresponding associations and subassociations) were determined in the JUICE program (TICHÝ 2002) by their fidelity values. Fidelity was calculated using the phi coefficient, applied to the classified data set with cluster sizes equalized to $1 / 3$ or $1 / 2$ respectively (in the case of searching for species diagnostic for two clusters together) of the size of the entire data set, of the total data set size according to TICHÝ and CHYTRÝ (2006). Species with phi $>30$ were considered as diagnostic for individual clusters, but species whose occurrence concentration in the plots of a particular cluster was not significant at $\mathrm{p}<0.05$ (Fisher's exact test) were excluded.

Unweighted average Ellenberg indicator values of relevés made on flooded sites, distances of the relevés from the streams (DMS, DCS) and relative elevation were passively projected onto a Principal Components Analysis biplot (PCA from CANOCO 4.5; TER BRAAK and ŠMILAUER 2002) to show ecological relationship among these relevés and to explain environmental gradients underlying the main ordination axes. Square root transformed cover data were used as the input data.

For further interpretation of the three clusters of flooded forests of the Mura River, unweighted average Ellenberg indicator values of 3 clusters of flooded forests, moisture and nutrient, which indicate the biggest correlations with axis 1 of the PC-ORD diagram, calculated in the JUICE program, and stream distances (DMS, DCS) were presented with Box-whiskers diagrams made in STATISTICA program (STATSOFT 2007). Boxes present mean and standard errors (SE), whiskers indicate standard deviations (SD).

Correlations of plant ecological strategies, life forms and origin and residence time status (native, archaeophyte, neophyte) and stream distance gradient were calculated with regression analysis, also in STATISTICA program. Each of the patterns was fitted with a linear regression model. The plant ecological strategies, life forms and plant status have been defined using the BIOLFLOR database (KLOTZ et al. 2002), that considers Grime's classification (GRIME 1979).

For the five most important tree species of the forests in the area, responses to the environmental variables (DCS, DMS) were fitted using the Huisman-Olff-Fresco models (HOF; HuIsman et al. 1993). HOF is a hierarchical set of five species response models with increasing complexity: model I-flat with no response, II-monotonously increasing or decreasing, III-monotonously increasing or decreasing with a »plateau«, IV-symmetric unimodal and $\mathrm{V}$-asymmetric unimodal response. Four parameters of these models were estimated using a non-linear maximum likelihood estimation procedure (OKSANEN and MiNCHIN 2002), available in Jari Oksanen's »gravy « library (http://cc.oulu.fi/\%7Ejraioksa/ softhelp/softalist.html) for the R program (http://www.r-project.org). This routine was run externally with R program (http://www.r-project.org) from the JUICE program (TICHÝ 2002), using a procedure developed by ZELENÝ and TICHÝ (2007) 


\section{Results}

The classification of the flooded forests of the Mura River is presented in the dendrogram (Fig. 1), and in the analytic table (Tab. 1). Classification into three clusters was accepted as it represents three ecologically interpretable vegetation types; 1. Salix alba and Populus nigra stands, 2. Fraxinus angustifolia subsp. oxycarpa stands and 3. Quercus robur and Carpinus betulus stands. The three clusters correspond to three communities; Salicetum albae Issler 1926, Fraxino-Ulmetum effusae Slavnić 1952 allietosum ursini subass. nova hoc loco, Fraxino-Ulmetum effusae Slavnić 1952 quercetosum robori subass. nova hoc loco.

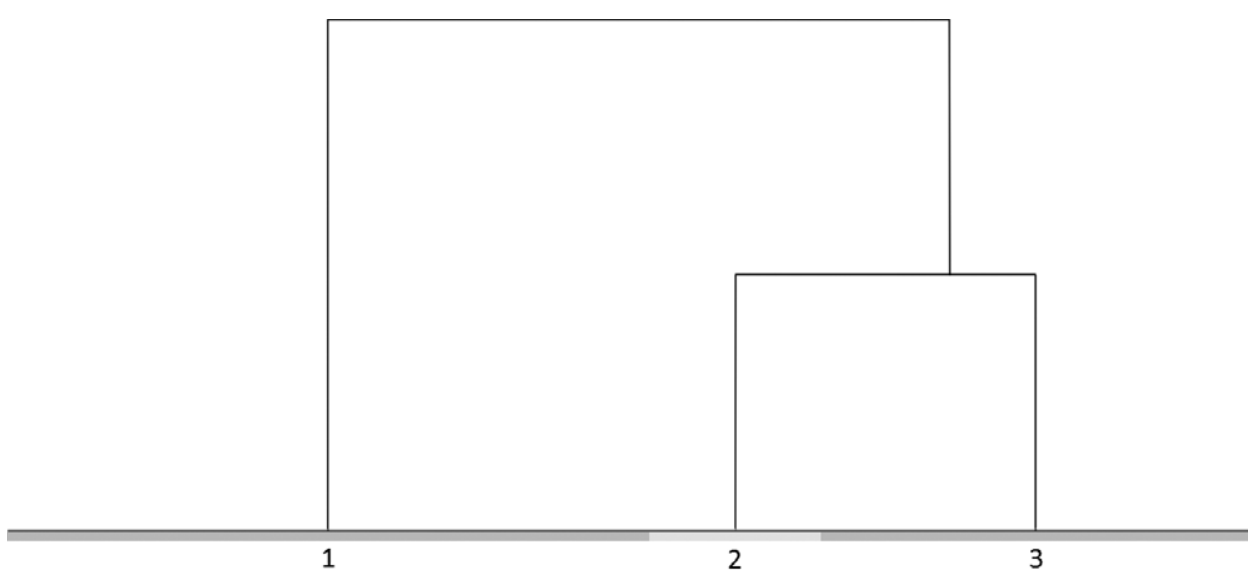

Fig. 1. Dendrogram of classification. Cluster 1: Salix alba and Populus nigra stands, cluster 2: Fraxinus angustifolia subsp. oxycarpa stands and cluster 3: Quercus robur and Carpinus betulus stands. For simplicity, the bottom part is not shown.

PCA is presented of the 58 relevés of flooded sites of the Mura River with Ellenberg indicator values (Fig. 2). Eigenvalues of the first two axes are 0.161 and 0.114 . The three communities (three clusters) thrive along a moisture and nutrient gradient. Moisture and nutrient indicator values are negatively correlated with DCS (with moisture -0.308 , with nutrients -0.341) and DMS (with moisture -0.224 , with nutrients -0.209 ). The association Salicetum albae (cluster one) occurs on the most moist and nutrient-rich sites, the subassociation Fraxino-Ulmetum effusae quercetosum robori (cluster three), on the other hand, occurs on the least moist and the least nutrient-rich sites (Fig 2, Fig. 3).

DCS is the lowest in cluster one (Salicetum albae) and the highest in cluster three (Fraxino-Ulmetum effusae quercetosum robori). DMS is also the highest in cluster three and lower in clusters one and two (Fraxino-Ulmetum effusae allietosum ursini). Cluster three shows the highest range of DMS indicating that the main stream of the Mura has the lowest effect on the distribution of Quercus robur stands, which can be also found relatively far (up to $3080 \mathrm{~m}$ far) from the main stream of Mura.

The proportion of neophytes is strongly significantly negatively correlated with DMS (Fig. 5), and not significantly correlated with DCS. The most abundant neophytes in our relevés are Robinia pseudacacia, Impatiens glandulifera, Solidago gigantea and Rudbeckia laciniata. 
KoŠIR P., ČARNI A., MARINŠEK A., ŠILC U.

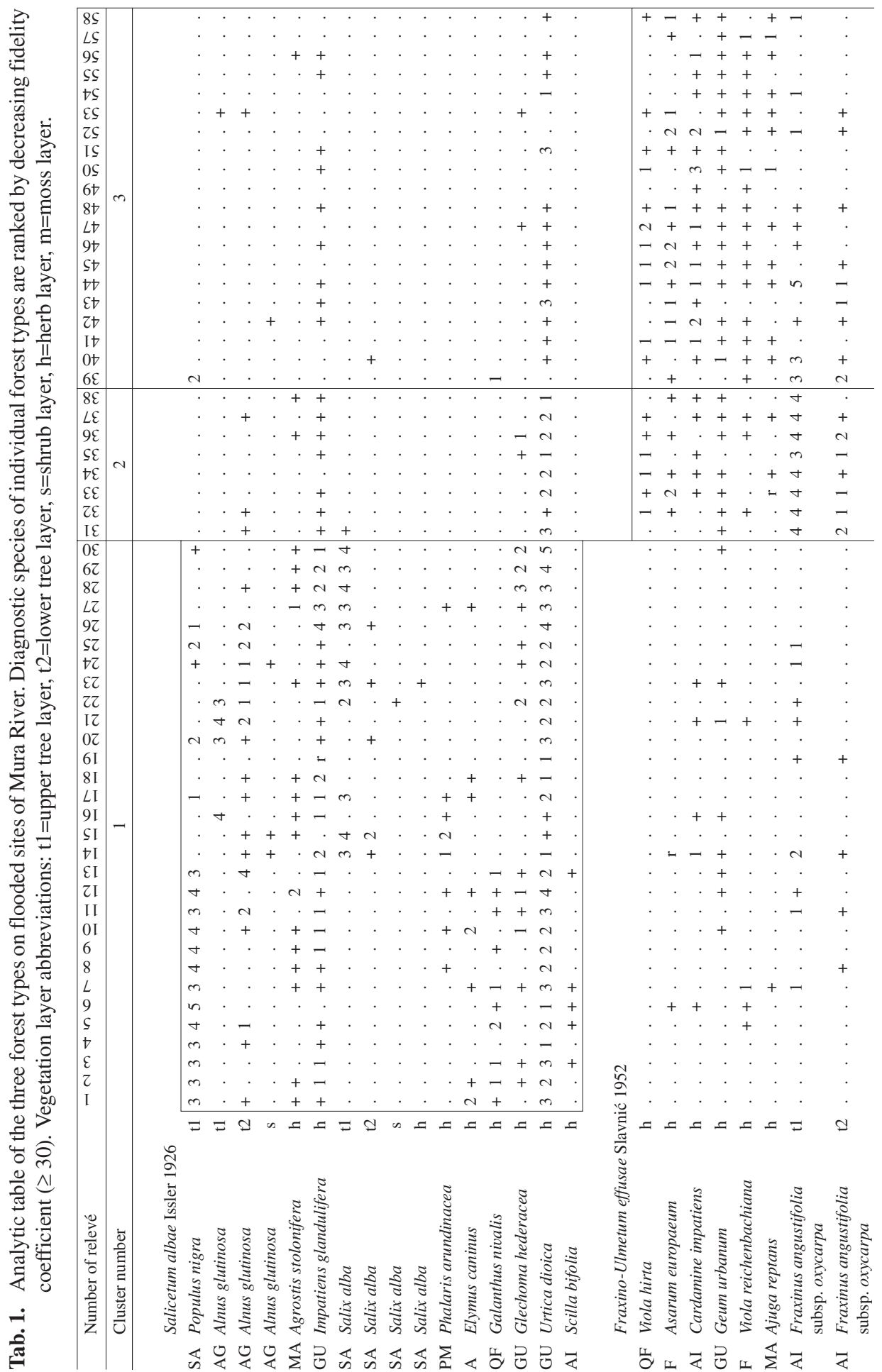




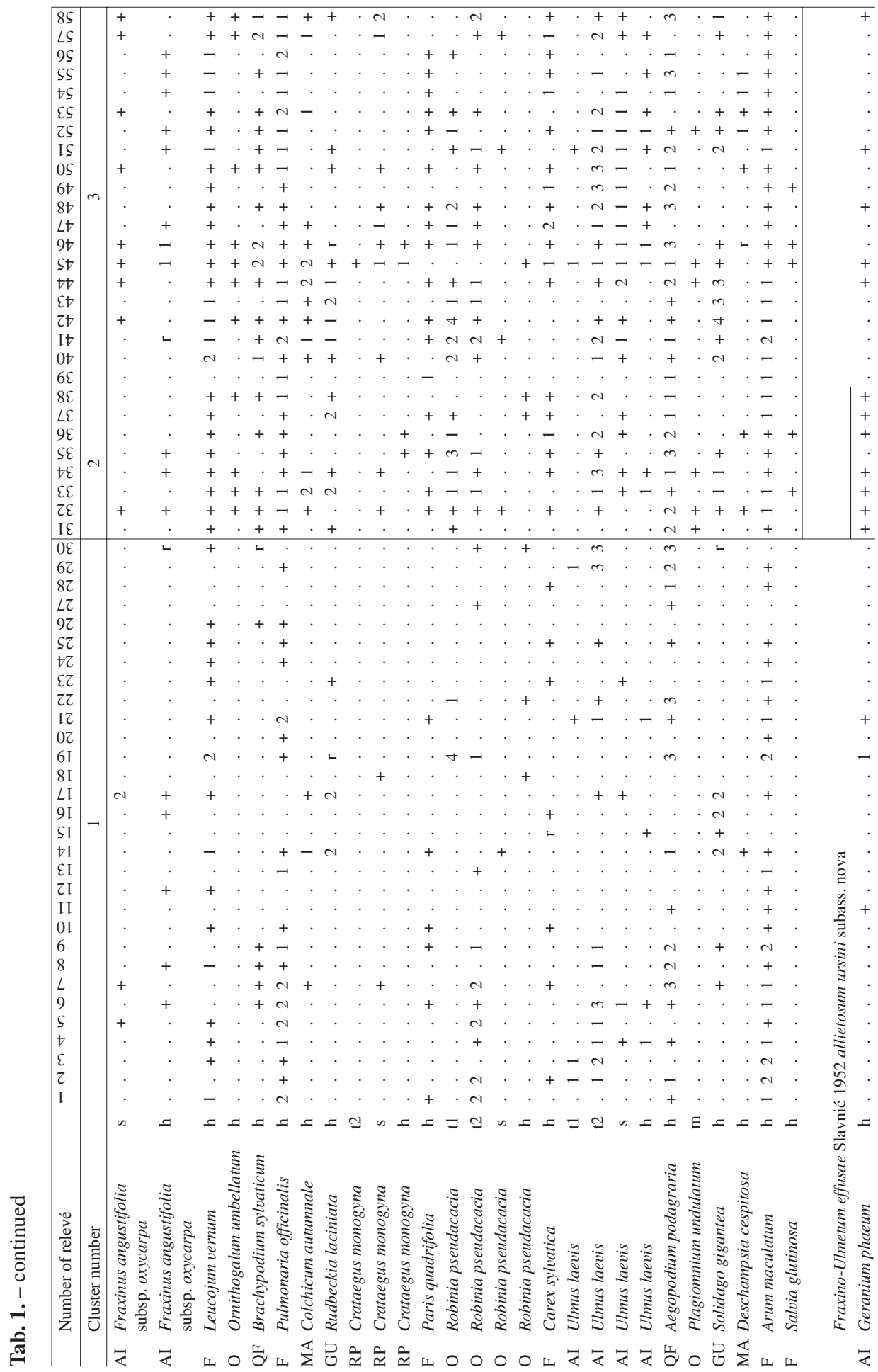


KoŠIR P., ČARNI A., MARINŠEK A., ŠILC U.

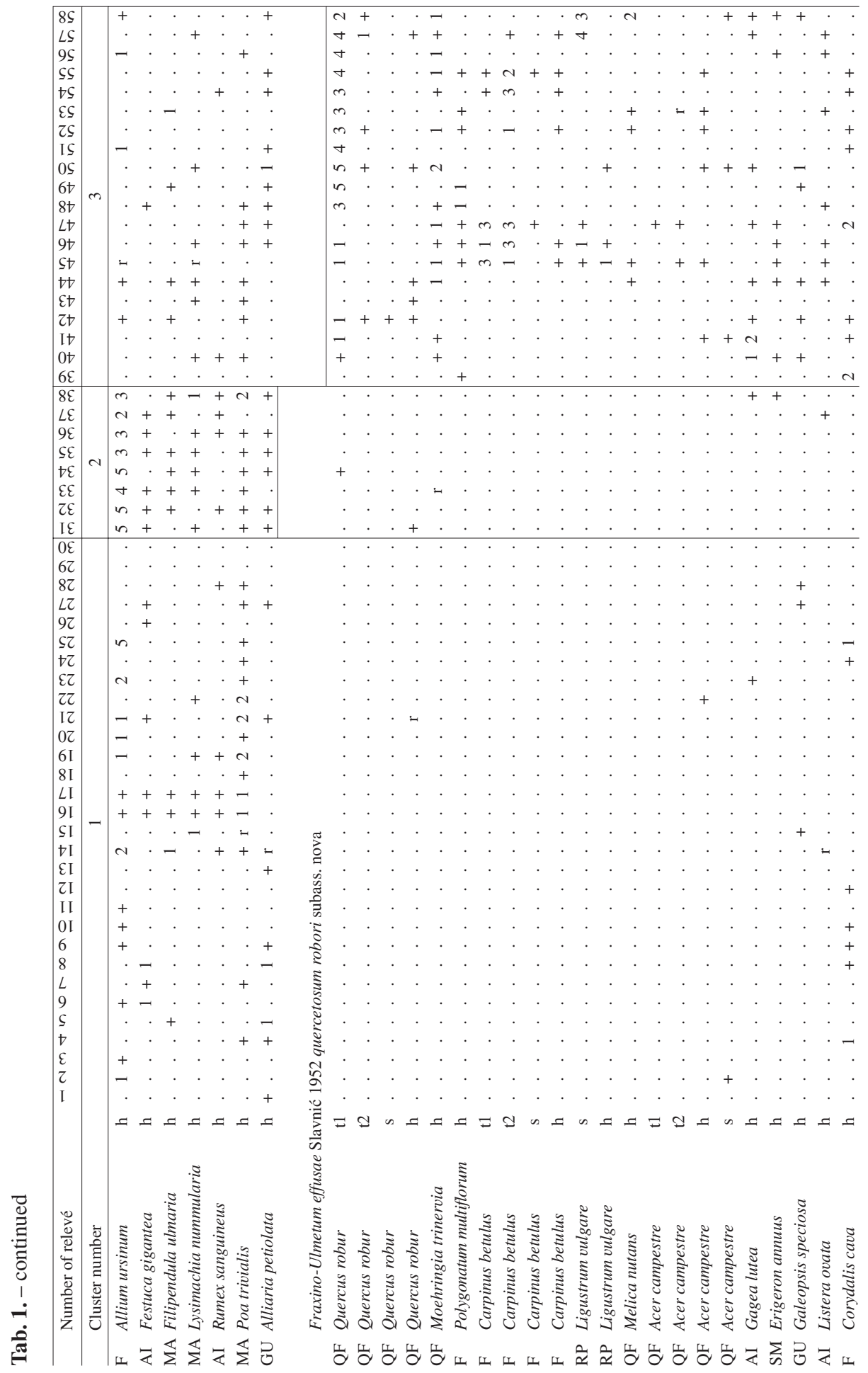




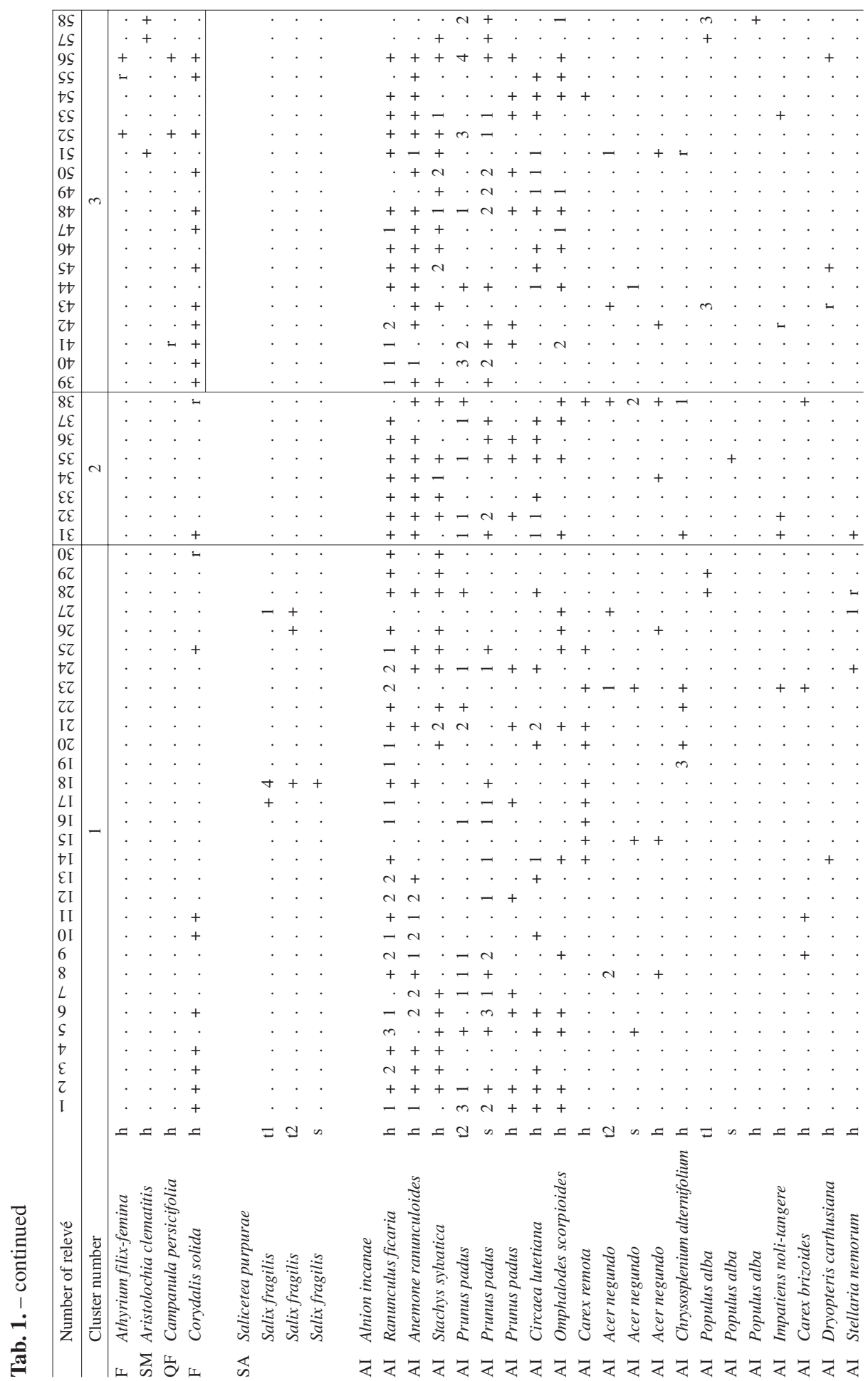


KoŠIR P., ČARNI A., MARINŠEK A., ŠILC U.

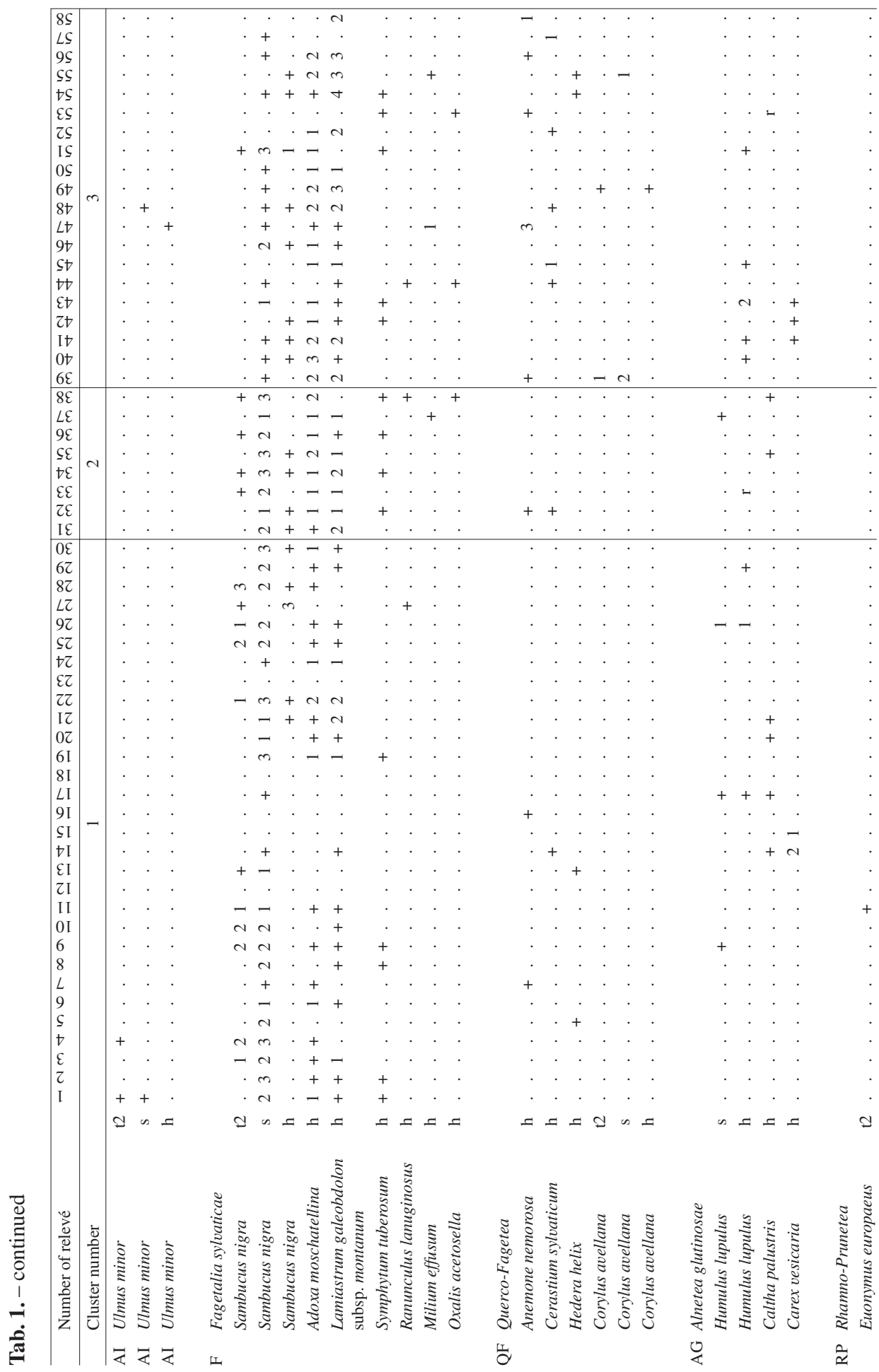




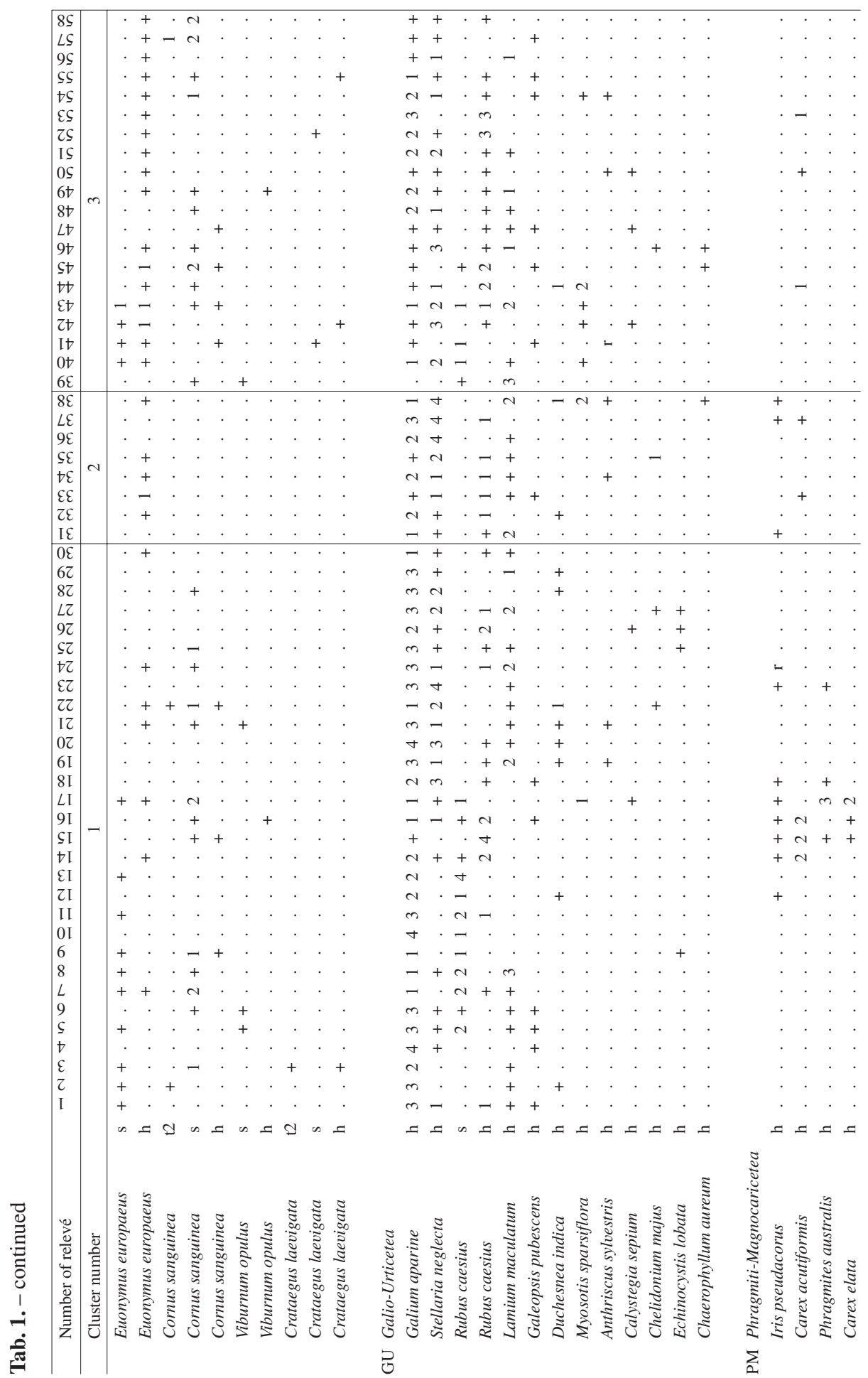


KoŠIR P., ČARNI A., MARINŠEK A., ŠILC U.

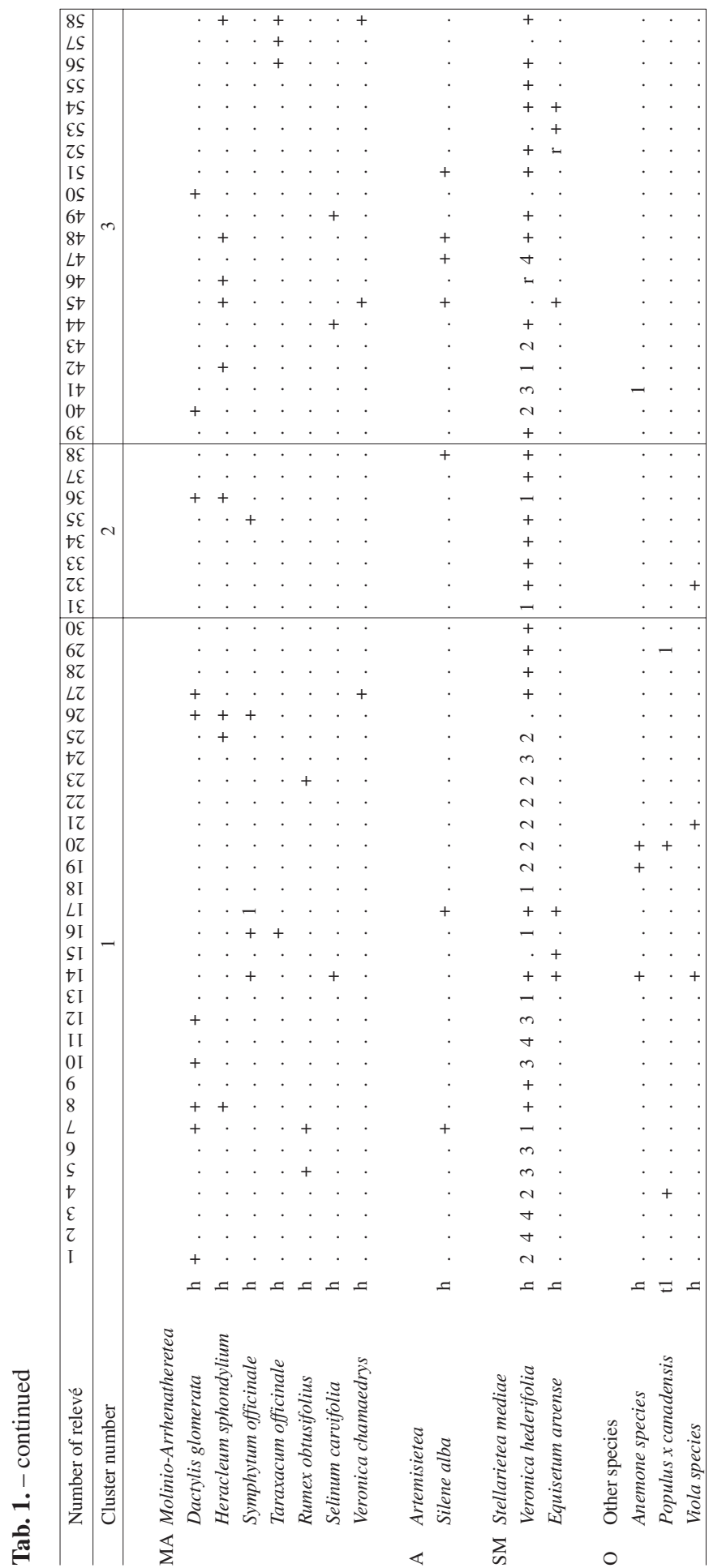

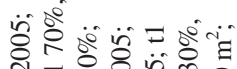

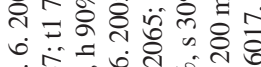

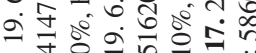

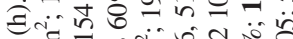

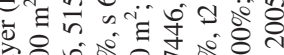

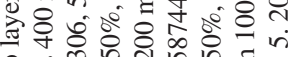

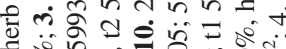

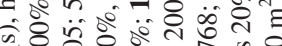

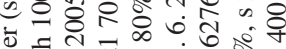

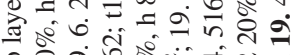

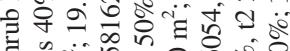
क ⿻ 1ิ80

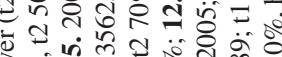
बिं

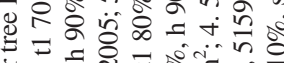

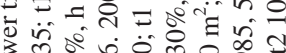

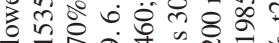

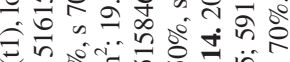

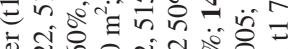

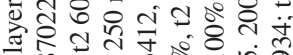
u ir $\forall \ddot{0} \ddot{0} \ddot{0}=\dot{0}$

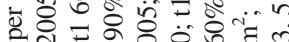

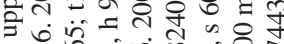

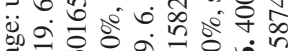
o응

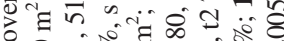
co

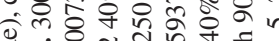

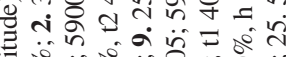

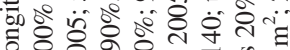
응ㅇㅇㅇㅇำ

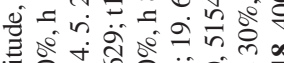

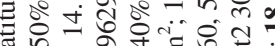
in w so o ñ

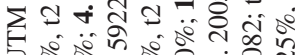
ट⿺辶。 औ

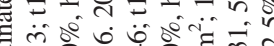

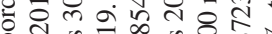

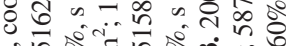

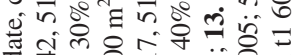

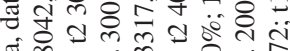

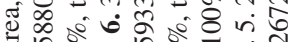
๙n

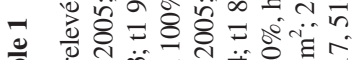

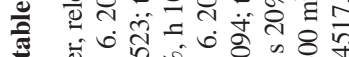
\& 20000

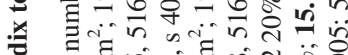

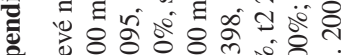

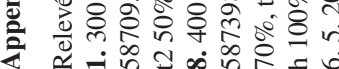




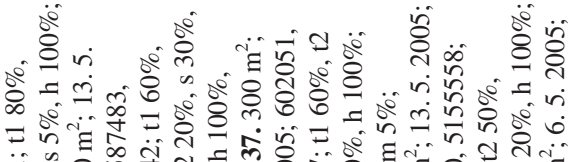
$\ddot{\bar{\sigma}}$ a 各

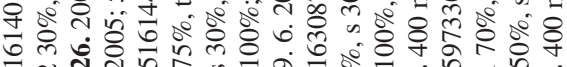

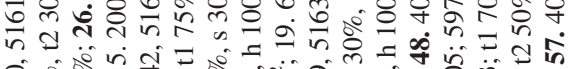

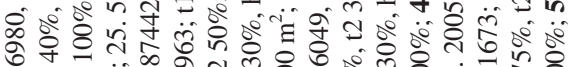
of J й

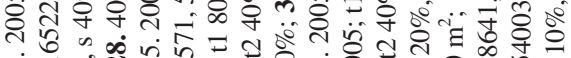

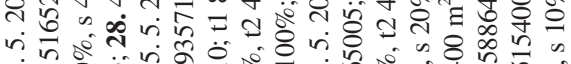

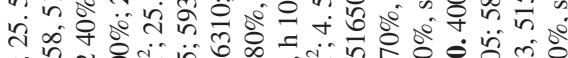

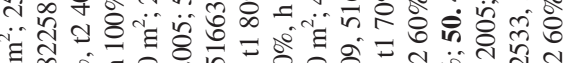

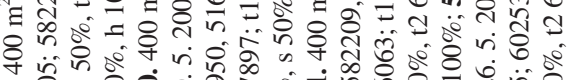

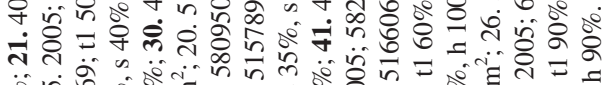

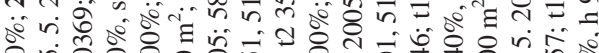

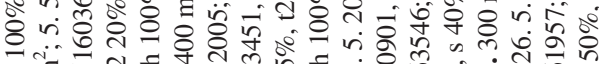
I

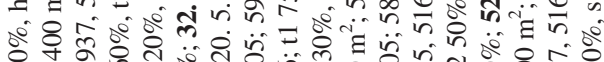

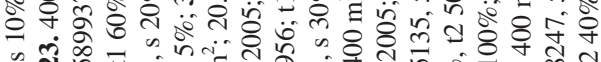
๓

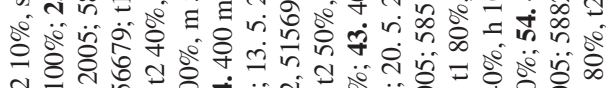

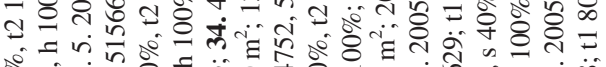

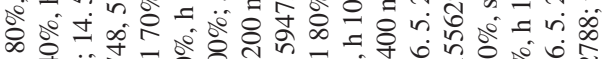

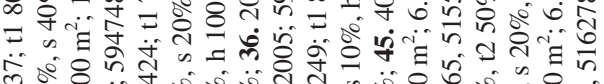

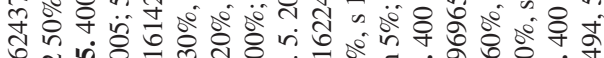

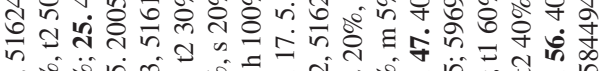

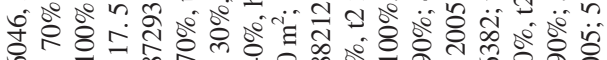
然

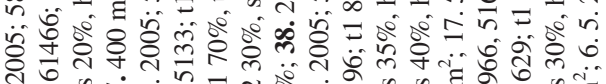

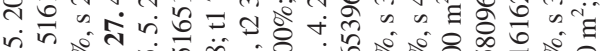
+

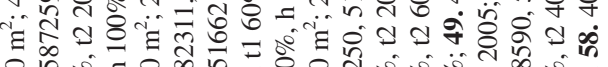

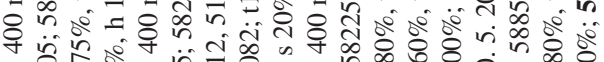

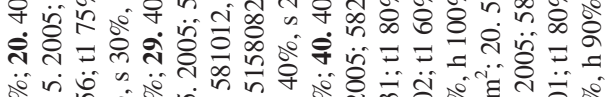

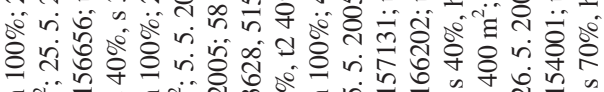

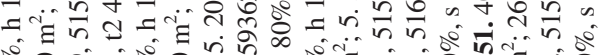

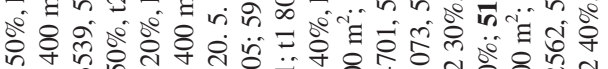

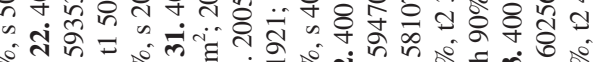

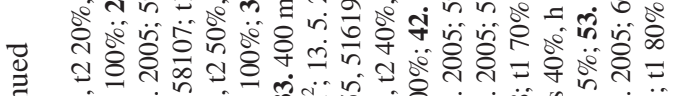
o든

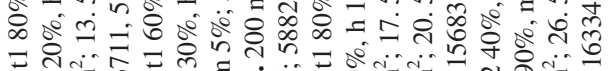

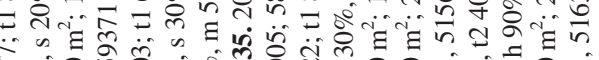

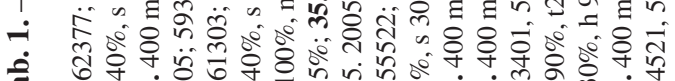

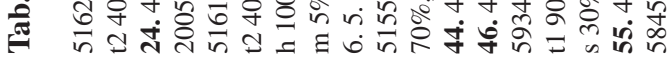

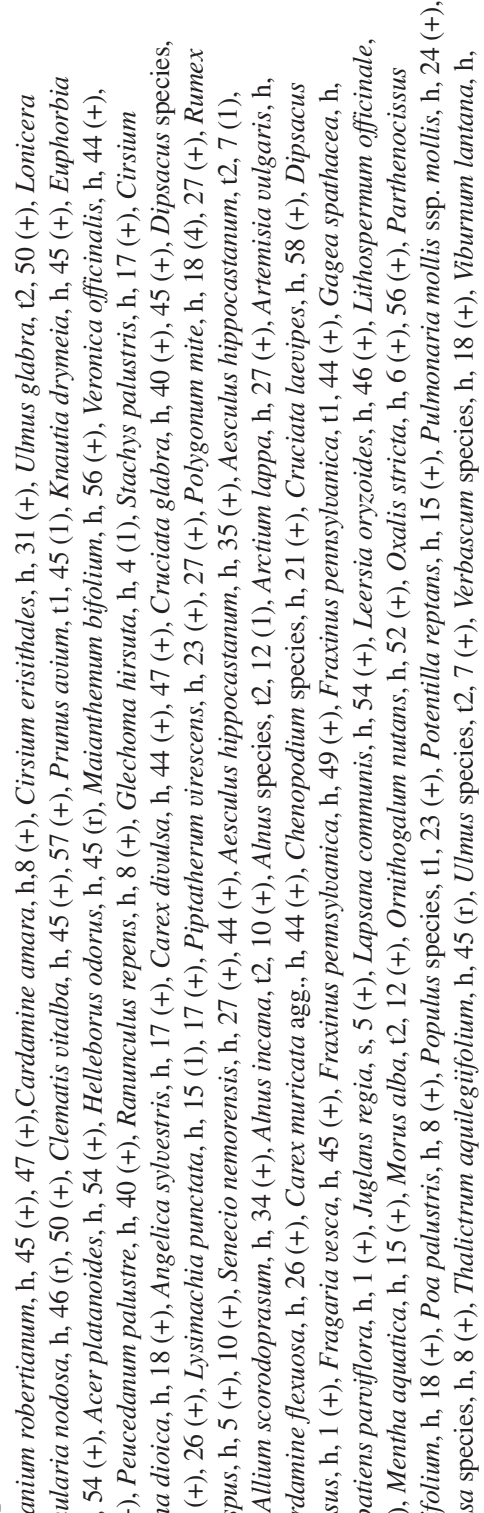

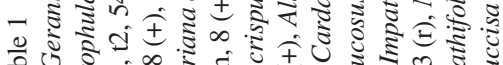

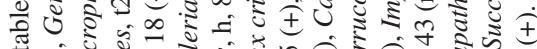

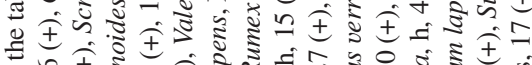

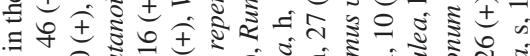

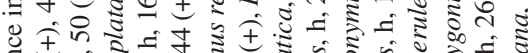

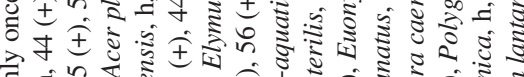

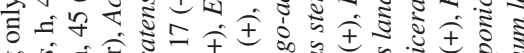

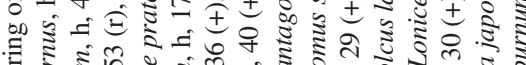

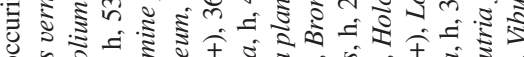

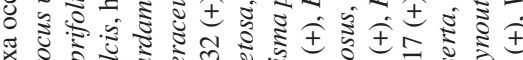

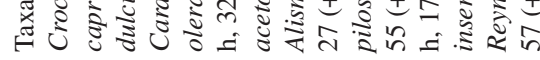


KOŠIR P., ČARNI A., MARINŠEK A., ŠILC U.

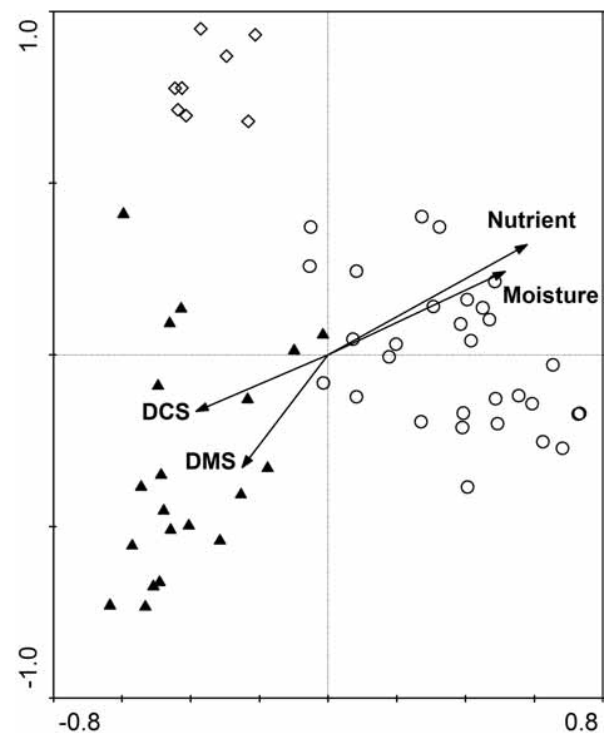

Fig. 2. Passive projection of Ellenberg indicator values and values of DCS and DMS onto the PCA diagram of relevés and species of flooded sites of the Mura River. Only indicator values with the highest correlations with the first two PCA axes are shown. The highest correlations with the first axis are shown by the indicator values for nutrients $(0.579)$, moisture $(0.515)$ and DCS (-0.384), with the second axis the values for DMS (-0.328). Legend: O Salix alba and Populus nigra stands (Salicetum albae Issler 1926), $\diamond$ Fraxinus angustifolia subsp. oxycarpa stands (Fraxino-Ulmetum effusae Slavnić 1952 allietosum ursini subass. nova hoc loco), Quercus robur and Carpinus betulus stands (Fraxino-Ulmetum effusae Slavnić 1952 quercetosum robori subass. nova hoc loco)
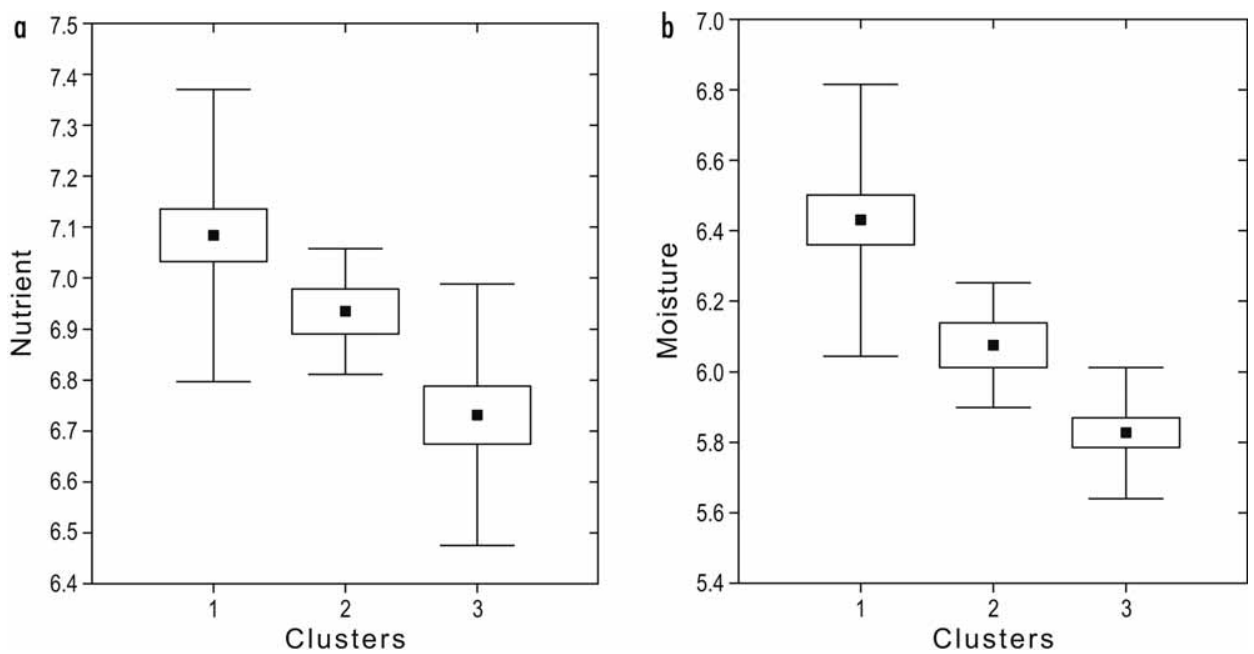

Fig. 3. Mean, standard error (box) and standard deviation (whiskers) of Ellenberg indicator values for nutrients (a) and moisture (b) of the three communities of the flooded forests. Communities (clusters) are numbered as in Fig.1. 

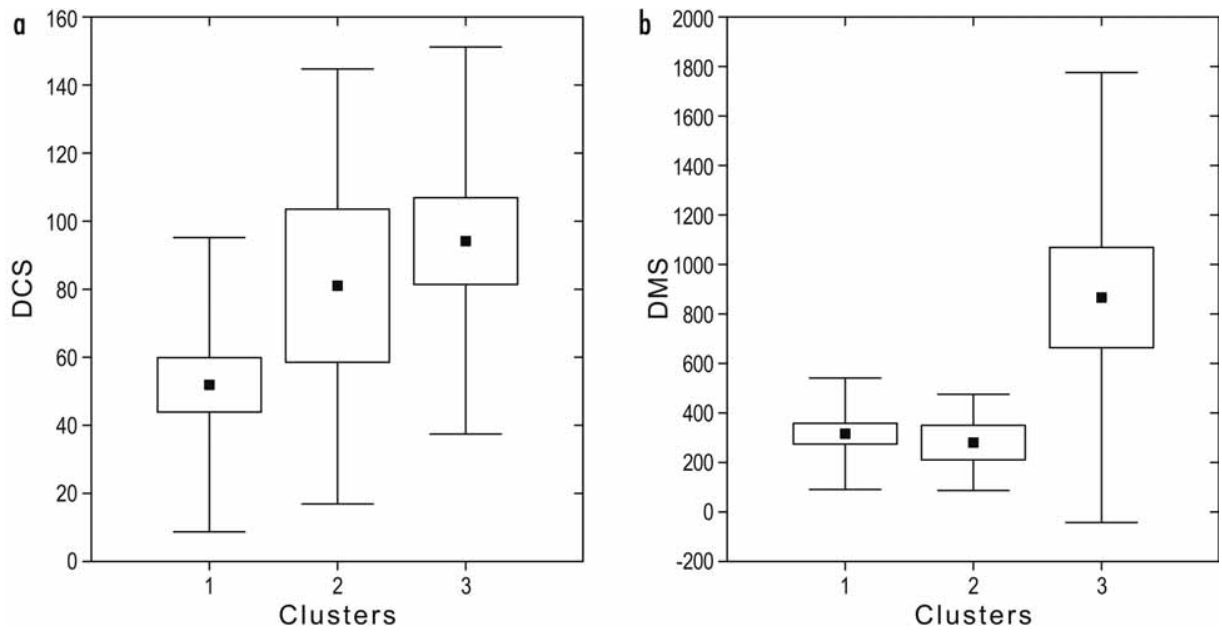

Fig. 4. Mean, standard error (box) and standard deviation (whiskers) of distance from the closest stream (DCS) (a) and distance from the main stream (DMS) (b) of the three clusters. Clusters are numbered as in Fig. 1.

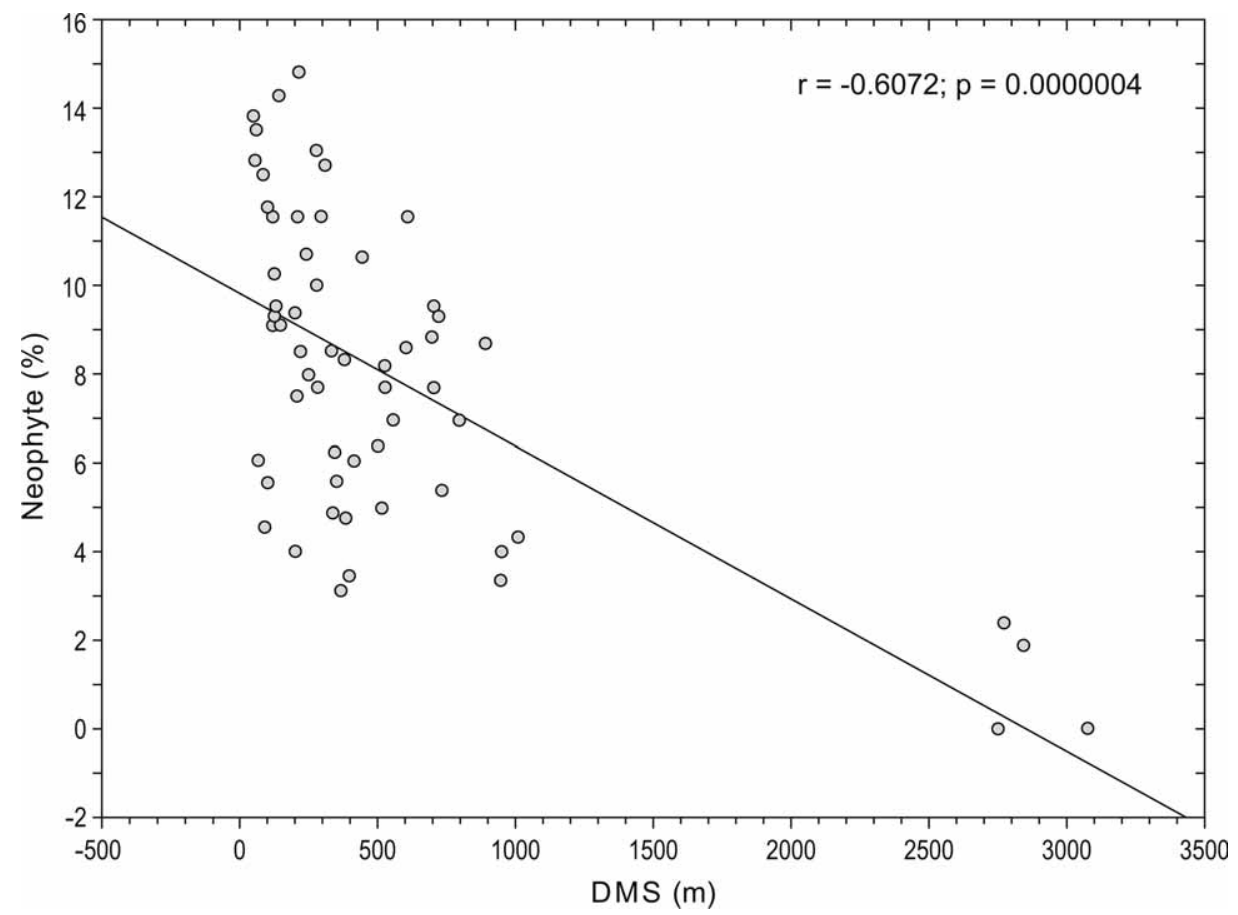

Fig. 5. Relation between the proportion of neophytes and increasing distance from the main stream (DMS).

In the case of life forms, correlation with DCS was very highly significant only in the case of therophytes (Fig. 6). Correlation with DMS was not significant in any case of life form. 
KoŠIR P., ČARNI A., MARINŠEK A., ŠILC U.

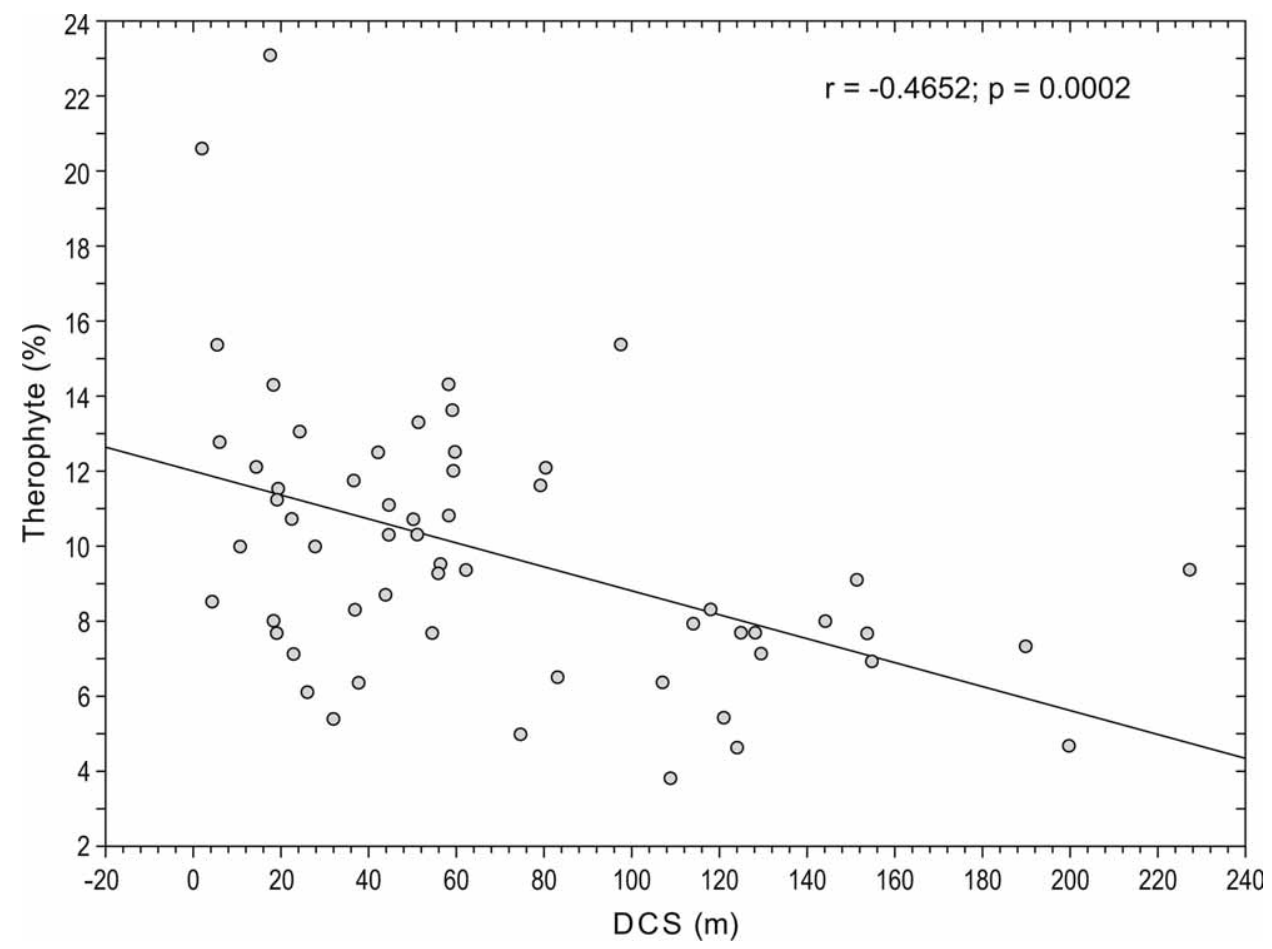

Fig. 6. Relation between the proportion of therophytes and increasing distance from the closest stream (DCS).

Correlations of ecological strategists and DCS and DMS was calculated with regression analysis. No analysis show statistical significant correlation.

In all three clusters hemicryptophytes represent the biggest proportion of species, geophytes and phanerophytes follow. Therophytes represent the smallest proportion of species in the relevés of three clusters (Tab. 2).

Tab. 2. Mean value of the share (\%) of life forms with standard deviations (SD) of the three clusters.

\begin{tabular}{lccc}
\hline life form & cluster 1 & cluster 2 & cluster 3 \\
\hline Hemicryptophytes & $37.6 \pm 8.96$ & $48.37 \pm 6.88$ & $41.67 \pm 6.87$ \\
Geophytes & $22.16 \pm 7.74$ & $21.62 \pm 2.94$ & $22.79 \pm 6.05$ \\
Phanerophytes & $20.95 \pm 5.4$ & $13.17 \pm 3.61$ & $20.47 \pm 5.62$ \\
Therophytes & $11.8 \pm 3.66$ & $7.68 \pm 1.57$ & $7.55 \pm 2.48$ \\
\hline
\end{tabular}

All three clusters consist of a mixture of different strategists (C-S-R, C, C-S, C-R and R). The proportions of CSR and C species were the highest in all three clusters (Tab. 3).

Species response curves fitted using HOF models (Fig. 7) describe the relationships among the main tree species of flooded forests of the Mura River and environmental variables DCS (Fig. 7a) and DMS (Fig. 7b). 
Tab. 3. Mean value of the share (\%) of C-S-R strategies with standard deviations (SD) of three clusters.

\begin{tabular}{lccc}
\hline strategy type & cluster 1 & cluster 2 & cluster 3 \\
\hline C-S-R & $36.25 \pm 8.07$ & $41.09 \pm 3.79$ & $41.14 \pm 5.5$ \\
C & $33.54 \pm 6.87$ & $27.07 \pm 3.18$ & $31.28 \pm 5.35$ \\
C-S & $10.8 \pm 5.15$ & $13.66 \pm 3.98$ & $11.81 \pm 2.28$ \\
C-R & $9.81 \pm 4.06$ & $6.81 \pm 1.55$ & $6.82 \pm 2.45$ \\
R & $4.25 \pm 1.5$ & $3.71 \pm 1.59$ & $3.67 \pm 2.22$ \\
\hline
\end{tabular}
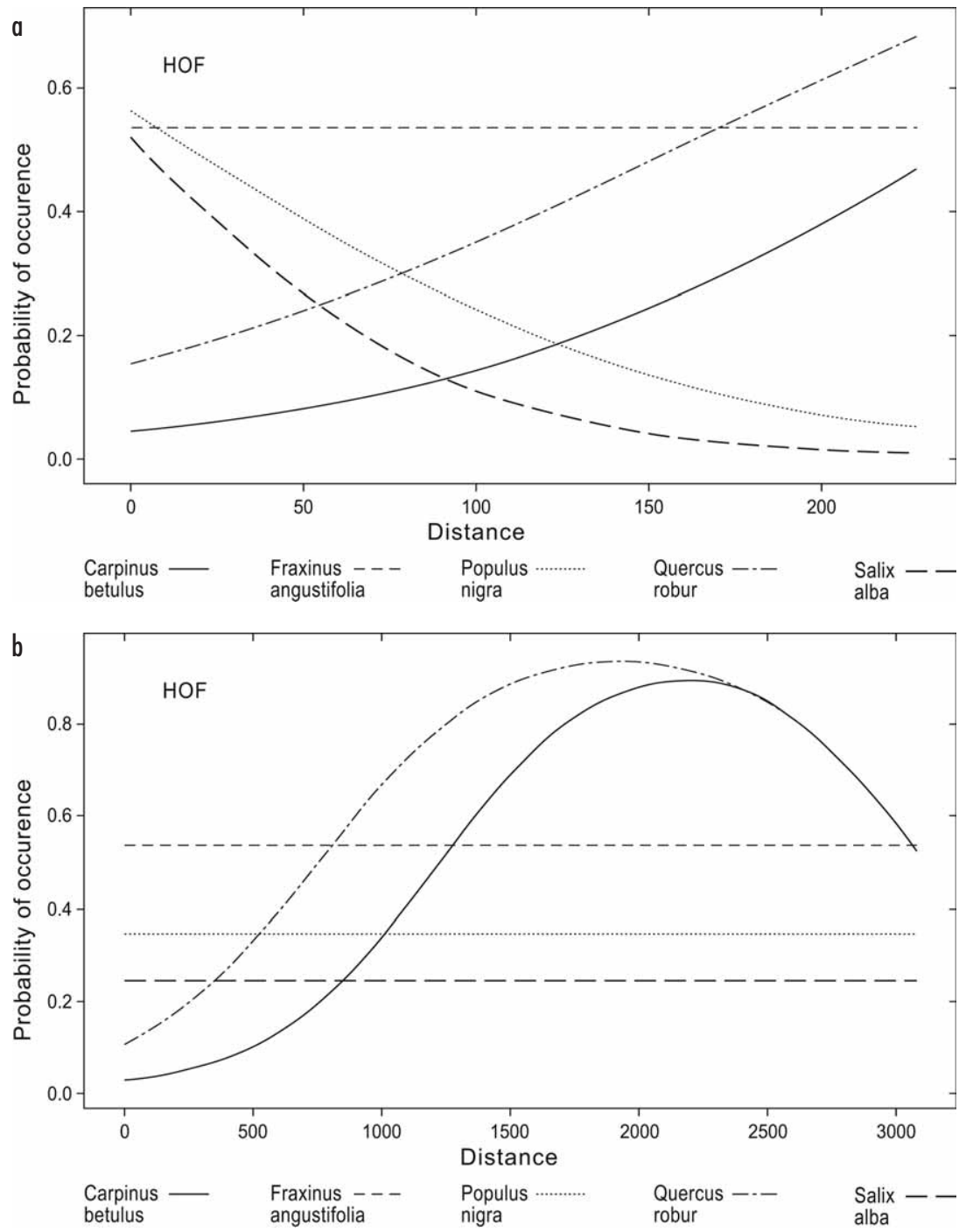

Fig. 7. Probability of occurrence of the main tree species of the area of the Mura River on the gradients of DCS (a) and DMS (b), modelled with the Huisman-Olff-Fresco models. Only species occurrences in the tree layer were considered for modelling. 
Carpinus betulus and Quercus robur respond to both DCS and DMS. They are found in areas distant from streams. Fraxinus angustifolia subsp. oxycarpa does not respond to either DCS or DMS. Salix alba and Populus nigra respond only to DCS and do not respond to DMS. Their response is the opposite of the response of Carpinus betulus and Quercus robur as they are found close to the stream.

\section{Discussion}

\section{Zonation of plant communities and ecological gradients}

The three forest vegetation types that appear on river banks were detected with numerical analysis (Fig. 1). The main ecological gradients that influence the species composition of these forests are nutrients and moisture, and they are negatively correlated with distance from the stream (DCS, DMS) (Fig.2). Moisture- and nutrient-rich plots are closer to the stream. Distance from the first closest stream (DCS) shows bigger correlation to species composition than DMS and it is the underlying gradient of vegetation zonation, which can be also seen from the DCS values of the three forest vegetation types (Fig. 4a). Three forest vegetation types are also ecologically delimited (Fig. 3a,b) as there is a distinction between the ecological values of the three groups of relevés. The values of relative elevation of the plots were much equalized, (as forests in depressions - floodplain swamp forests - were not included), and therefore do not influence species composition.

The three communities have been classified into syntaxa, as follows.

Syntaxonomical scheme:

Salicetea purpurae Moor 1958

Salicetalia purpurae Moor 1958

Salicion albae Soó 1930

Salicetum albae Issler 1926

Querco-Fagetea Br.-B1. et Vlieger 1937

Fagetalia sylvaticae Pawlowski in Pawlowski et al. 1928

Alnion incanae Lüdi 1921

Fraxino-Ulmetum effusae Slavnić 1952 subass. allietosum ursini subass. nova hoc loco Holotypus: relevé number 31 in Tab. 1 holotypus hoc loco

Fraxino-Ulmetum effusae Slavnić 1952 subass. quercetosum robori subass. nova hoc loco Holotypus: relevé number 48 in Tab. 1 holotypus hoc loco

In the central part of Europe along big rivers the hardwood association Querco-Ulmetum minoris Issler 1926 (syn. Fraxino-Ulmetum Tx. ex Oberd. 1953) is distinguished by the dominant species Quercus robur, Ulmus minor/laevis, Fraxinus excelsior. In central eastern and south eastern Europe a hardwood association with different Fraxinus species Fraxinus angustifolia subsp. oxycarpa (Fraxino-Ulmetum effusae Slavnić 1952 (syn. Fraxino pannonicae-Ulmetum Soó 1936 corr. 1963)) is the one that occupies the highest positions in floodplain areas along large rivers (WILLNER and GRABHERR 2007, NEUHÄUSLOVÁ et al. 2001, BORHIDI and KEVEY 1996, VICHEREK et al. 2000, VuKELIĆ and BARIČEVIĆ 2004, 2005, RAUŠ 1976, 1992, SLAVNIĆ 1952). That association was first correctly described by Slavnić in 1952 in the floodplain area of Vojvodina (Serbia) along rivers Drava and 
Danube. The reference of SLAVNIĆ (1952) was overlooked by most European researchers who recognized the name Fraxino pannonicae-Ulmetum Soó 1936 corr. 1963 given by Soó (1963) as the correct one.

\section{Description of the syntaxa (Tab. 1, Fig. 3a, b)}

\section{Salicetum albae Issler 1926}

This community occurs along streams, on floodplains and along gravel pits. Along the Mura the white willow (Salix alba) and poplar tree (Populus nigra) form a relatively wide belt of riparian vegetation. These tree species dominate the stands and are also diagnostic species of the association. In the tree layer there are also Alnus glutinosa, Salix fragilis, Ulmus laevis, Fraxinus angustifolia subsp. oxycarpa, Prunus padus and Robinia pseudacacia. The stands are often inundated and the ground water is high. The soil is structureless. Sedimentation is the result of inundation and alluvium deposits and its layers are clearly defined. Diagnostic species (Tab. 1) such as Impatiens glandulifera, Agrostis stolonifera, Elymus caninus, Urtica dioica etc. indicate moist and nutrient-rich, regularly disturbed sites. The large surfaces of the sites of this community were reclaimed in the past and planted with different cultivars of hybrid poplar and alder. The association is widely accepted and described all over Europe.

\section{Fraxino-Ulmetum effusae Slavnić 1952}

The community occurs in a wide belt along the Mura above the belt formed by white willow forests. In the area of Mura river we detected two subassociations of this association (subass. allietosum ursini and subass. quercetosum robori);

Fraxino-Ulmetum effusae Slavnić 1952 subass. allietosum ursini subass. nova. It occurs fragmentarily on finely structured alluvial soil. The sites are only occasionally flooded. The community is confined to the association Salicetum albae. In the tree layer species Fraxinus angustifolia subsp. oxycarpa dominates the stands, while Ulmus laevis, Robinia pseudacacia and Prunus padus also frequently occur. The diagnostic species are characteristic for moist, fresh, nutrient rich sites: Geranium phaeum, Allium ursinum (dominates the herb layer), Festuca gigantea, etc. In the vegetation map of forest communities of the area of Murska Sobota (ČARNi et al. 2008) forests of this subassociation were treated as a variant of Fraxino-Ulmetum effusae Slavnić 1952 var. Prunus padus Vukelić et Baričević 2004.

Fraxino-Ulmetum effusae Slavnić 1952 subass. quercetosum robori subass. nova. In terms of development, this forest type is the most mature and stable in the inundated region, it is the least nutrient rich and the least moist of the three vegetation types (Fig. 3). The dominant tree species in the tree layer is Quercus robur, sometimes also Carpinus betulus, Fraxinus angustifolia subsp. oxycarpa, Robinia pseudacacia and Ulmus laevis. The group of diagnostic species is large, and most species are of ordo Fagetalia (alliance Alnion incanae) and classes Rhamno-Prunetea and Galio-Urticetea. In the vegetation map of forest communities of the area of Murska Sobota (ČARNI et al. 2008) forests of this subassociation were treated as the association Genisto elatae-Quercetum roboris Horvat 1938. Later on, recent analysis showed that this vegetation type was more related to the association Fraxino-Ulmetum than to the association Genisto elatae-Quercetum. SLAVNIĆ (1952) was among the first to point out that the community Fraxino-Ulmetum displays a significant floristic affiliation with the Slavonian forest of pedunculate oak Genisto elatae- 
-Quercetum roboris; however these are two separate systematic units. The community Fraxino-Ulmetum effusae inhabits the highest position of floodplain areas along large rivers, all these areas being exposed to periodical flooding. On the other hand, the community of Genisto elatae-Quercetum occurs in swamps along boggy backwaters, where mollic gleysol is formed (VuKELIĆ and BARIČEVIĆ 2004).

Both the above described subassociations of association Fraxino-Ulmetum effusae correspond well to forests along the upper course of the river Drava (around Varaždin) in Croatia near to Slovenia described by VuKELIĆ and BARIČEVIĆ (2004) as Fraxino-Ulmetum variant Prunus padus (drier variant). As the difference between the variant Prunus padus and variant typicum (more humid variant along the Danube River and lower part of the Sava River) described by the same authors, is significant, we propose a description of subassociations.

Zonation of forest vegetation can also be evidenced in a response curve of the main edifiers of plant communities (Fig. 7a) on the gradient of DCS. Salix alba and Populus nigra, edifiers of association Salicetum albae, are found close to streams and their occurrence decreases with the distance from the stream. The probability of occurrence for the tree species Quercus robur and Carpinus betulus, edifiers of the variant Fraxino-Ulmetum subass. quercetosum robori, increases with distance from the stream. The tree species Fraxinus angustifolia does not respond to DCS, its probability of occurrence is equalized on the gradient of distances, and therefore gets a chance to become dominant in stands in the middle of the distance gradient (Fraxino-Ulmetum subass. allietosum ursini), where the occurrence of Salix and Populus falls and the increasing occurrence of Quercus and Carpinus is still low. Response curve of main edifiers of plant communities in the gradient of DMS on the other hand proved the already established fact that DMS is not an underlying gradient for the zonation of forest vegetation.

\section{Distribution of plant functional types along stream distance gradient}

The group of life forms is a good indicator of disturbance. Short-living species (like therophytes) are favoured by continual disturbance, therefore cover value of therophytes is higher in flooded stand compared to unflooded stands. Long-living species (geophytes, phanerophytes) on the other hand, benefit from the interruption of inundation or from long habitat continuity (GLAESER and WULF 2009). In our case too, the proportion of therophytes in the relevés close to the stream is bigger and decreases with distance from it (Fig. 6). That is because the stands close to the stream are more disturbed by floods, deposition and removal of nutrient material. Other life forms show no statistical significant correlation with DCS as has been already found out also for some other plant communities along the moisture gradient (ZELNIK and ČARNI 2008).

Riparian habitats are considered to be particularly prone to invasion by alien plant species (TICKNER et al. 2001). The expansion of neophytes (alien species introduced to the region after the year 1500 A.D.) in river-floodplain systems characterized the 20th century as human alterations to these systems, such as channel modifications, flow regulation, and floodplain drainage, intensified (SCHNITZLER et al. 2007, TABACCHI et al. 1996). Many alien species are typically wetland species (ZEDLER and KERCHER 2004, SKAÁLOVA and PYŠEK 2009), and some of them have also high nutrient demands (SCHNITZLER et al. 2007). Close to the river the abundant supply of water and the high nutrient content of freshly deposited 
sediments combine with the typically plentiful light availability to promote the successful germination and establishment of alien species (SANCHEZ-PEREZ et al. 1993, SchNitzLER et al. 2003).

As we tested the proportion of neophytes in the stands and their correlation to DCS and DMS, surprisingly there were no significant correlations with DCS, but there was a significant correlation with DMS (Fig. 5). This means that bigger occurrence of neophytes is not connected to certain type of vegetation (willow stands because of their community architecture promote light in the understoreys) as has been reported (SCHNITZLER and Aumaitre 2008). Also in the area of Mura the best preserved willow stands are along side streams (and not along the main stream) as vegetation close to main stream is much more affected by different human impacts. A more important factor is the proximity of the main stream alone, which beside promotion of light (there are many open and disturbed areas near the main stream) assures active dispersal of rhizomes or stems (vegetative matter and seeds) deposited during floods and thereby encourages propagation (SCHNITZLER et al. 2007, RicHARDSON et al. 2007). The flow of the main stream is quick and never drains up, in contrast to side streams.

Both groups of species (neophytes and therophytes) are characteristic of disturbed sites. The proportion of therophytes is significantly negatively correlated with the distance from the closest stream (DCS), which can be easily understood and has been observed and explained already by other authors. More surprising is that neophytes do not respond to environmental factors in the same way as therophytes. A proportion of neophytes does not correlate with the same distance - distance from the closest stream (DCS), but with distance from the main stream (DMS). It seems that for establishment of neophytes, the propagation assured with the flow of the main stream is one of the most important factors beside disturbance itself.

Strong correlations of ecological strategy and moisture gradient have already been detected for some other vegetation types (ZELNIK and ČARNI 2008, TURNER et al. 2004, GLAESER and WULF 2009). Relative elevation and distance from main channel, as indicators of flooding regime, were reported to be consistently important in predicting occurrence, community composition and abundance of species (TURNER et al. 2004, MENGES and WALLER 1983). In our case the distribution of plant ecological strategies indicates similar habitat conditions along transecst from the streams, as there is no statistical significant correlation of plant ecological strategies with DMS and DCS. All relevés were made inside the area of frequent floods (inside dikes) on quite equalized elevations. In our study all three types of vegetation show similar proportions of plant ecological strategies in their compositions.

\section{Conclusion}

The present study contributes basic data on the floristic composition and structure of floodplain forests of Mura river. The zonation of floodplain forests is connected to distance from the closest stream (DCS) and not from the main stream (DMS). Distance from the closest stream influences species distribution through ecological gradients of moisture and nutrient. Three types of forests have been detected along these gradients. The proportion of therophytes is significantly negatively correlated with the distance from the closest stream and the proportion of neophytes is significantly negatively correlated with distance from the 
main stream. The correlation of proportion of neophytes with DMS can be explained by the importance of their effective propagation ensured by flow of the main stream.

\section{Acknowledgements}

Our study was supported by the Ministry of Agriculture, Forestry and Food and Ministry of Higher education, Science and Technology. It was carried out as part of a project V-40983: Ecological circumstances as basis for forest economy and also as part of a research programme P1-0236: Gradients and Biodiversity.

\section{References}

ACCETTO, M., 1994: Moor and flooded forests. Design of ecosystems division (in Slovenian). Oddelek za Biologijo, Biotehniška fakulteta, Ljubljana.

Borhidi, A., Kevey, B., 1996: An annotated checklist of the Hungarian plant communities. In: BoRHIDI, A. (ed.), Critical revision of the Hungarian plant communities, 95-138. Janus Pannonius University, Pécs.

Braun-Blanquet, J., 1964: Pflanzensoziologie. Grundzüge der Vegetationskunde. Springer, Wien.

ČArni, A., KoŠIR, P., MARINČEK, L., MARINŠEK, A., ŠILC, U., ZElniK, I., 2008: Commentary to the vegetation map of forest communities of Slovenia in scale 1:50.000 - section Murska Sobota. Pomurska akademsko znanstvena unija (PAZU), Murska Sobota.

DAKSKOBleR, I., ŠILC, U., ČUŠIN, B., 2004: Riverine forests in the Upper Soča valley (The Julian Alps, western Slovenia). Hacquetia 3, 51-80.

Deiller, A.-F., Walter, J.-M. N., TrÉMOlieres, M., 2001: Effects of flood interruption on species richness, diversity and floristic composition of woody regeneration in the upper Rhine alluvial hardwood forest. Regulated Rivers: Research and Management 17, 393-405.

Glaeser, J., Wulf, M., 2009: Effects of water regime and habitat continuity on the plant species composition of floodplain forests. Journal of Vegetation Science 20, 37-48.

Glavać, V., 1975: Das Pruno-Fraxinetum Oberdorfer 53 in Nordwestkroatien. Beiträge zu naturkundlichen Forschung in Südwestdeutschland-DT1 35, 95-101.

GlobeVnik, L., Mikoš, M., 2009: Boundary conditions of morfodynamic processes in the Mura River in Slovenia. Catena 79, 265-276.

GORŠAK, B., BAKAN, B., 2003: Mura nature park (in Slovenian). Proteus 7, 311-322.

GRIME, J. P., 1979: Plant strategies and vegetation processes. Wiley, Chichester.

HoRvat, I., GLAVAČ, V., Ellenberg, H., 1974: Vegetation Südosteuropas. Geobotanica selecta 10. Gustav Fischer Verlag, Stuttgart.

Hennekens, S. M., SchaminéE, J. H. J., 2001: TURBOVEG, a comprehensive data base management system for vegetation data. Journal of Vegetation Science 12, 589-591.

Huisman, J., OlfF, H., Fresco, L. F. M., 1993: A hierarchical set of models for species response analysis. Journal of Vegetation Science 4, 47-58.

Kevey, B., 2008: Forest associations of Hungary (in Hungarian). Tilia 14, 1-489. 
Klimo, E., Hager, H., 2001: Executive summary. In: Klimo, E., Hager, H. (eds.), The floodplain forests in Europe. Current situation and perspectives, 7-11. European Forest Institute Research report 10, Brill, Leiden.

Klimo, E., Hager, H., Matič, S., Anič, I., KulhavÝ, J. (eds), 2008: Floodplain forests of temperate zone of Europe. Lesnicka prace, s.r.o., Kostelec nad Černými lesy.

Klotz, S., KüHN, I., DuRKA, W., 2002: BIOLFLOR: Eine Datenbank mit biologisch-ökologischen Merkmalen zur Flora von Deutschland. Schriftenreiche für Vegetationskunde $38,1-334$.

Machar, I., 2001: Floodplain forest in Hornomoravský úval, Czech Republic. In: KLIMO, E., Hager, H. (eds.), The floodplain forests in Europe. Current situation and perspectives, 37-50. European Forest Institute Research Report 10, Brill, Leiden.

McCunE, B., MeFFoRd, M. J., 2005. PC-ORD, Multivariate analysis of ecological data, Version 5 for Windows edition. MjM Software Design, Gleneden Beach.

Menges, E. S., Waller, D. M., 1983: Plant strategies to elevation and light in floodplain herbs. The American Naturalist 122, 454-473.

Mitsch, W. J., GosselinK, J. G., 2000: Wetlands, 3. John Wiley, New York.

Müller, T., 1992: Verband: Alno-Ulmion. In: OBERDORFER, E. (ed.), Süddeutsche Pflanzengesellschaften. Wälder und Gebüsche, 173-192. Gustav Fischer Verlag, Jena.

Nemesszeghy, L., 1986: Black alder in Prekmurje (in Slovenian). Pomurska založba, Murska Sobota.

NeuhäuslovÁ, Z., Moravec, J., Chytrý, M., LožEK, V., RybníčEK, K., RybníčEKovÁ, E., Husová, M., Grulich, V., Jeník, J., SÁdlo, J., JiRÁseK, J., KolbeK, J., Wild, J., 2001: Potential natural vegetation of the Czech Republic. Braun-Blanquetia 30, 1-80.

Oksanen, J., Minchin, P. R., 2002: Continuum theory revisited: what shape are species responses along ecological gradients? Ecological Modelling 157, 119-129.

PAal, J., RAnNiK, R., Jeletsky, E.-M., Prieditis, N., 2007: Floodplain forests in Estonia: Typological diversity and growth conditions. Folia Geobotanica 42, 383-400.

Petrinec, V., 1999: Vegetationsmonographie von Šturmovci (NO-Slowenien). Diplomarbeit, Universität Wien.

Poldini, L., Vidali, M., Ganis, P. 2011: Riparian Salix alba: Scrubs of the Po lowland (N-Italy) from an European perspective. Plant Biosystems 145 (Suppl. 1), 132-147.

RAUš, Đ., 1976: Vegetation of marshlands forests in Podunavlje between Alajmaš and Ilok (in Croatian). Annales pro Experimentis Foresticis 19, 5-75.

RAUŠ, Đ., 1992: Vegetation of marshlands forests along the river Drava between Varaždin and Osijek with particular attention paid to the Varaždin forests along the river (in Croatian). Annales pro Experimentis Foresticis 28, 245-256.

Richardson, D. M., Holmes, P., Esler, K. J., Galatowitsch, S. M., Stromberg, J. C., Kirkman, S. P., PyšEK, P., HobBS, R. J. 2007: Riparian vegetation: degradation, alien plant invasions, and restoration prospects. Diversity and Distribution 13, 126-139.

Sanchez-Perez, J. M., Trémolières, M., Schnitzler, A., Badre, B., CArbiener, R., 1993: Nutrient content in alluvial soils submitted to flooding in the Rhine alluvial deciduous forest. Acta Oecologica 14, 371-387. 
KoŠIR P., ČARNI A., MARINŠEK A., ŠILC U.

SLAVNIĆ, Ž., 1952: Lowland forests of Vojvodina (in Sebian). Zbornik Matice Srpske 2, $17-38$.

SCHNITZLER, A., 1994: European alluvial hardwood forests of large floodplains. Journal of Biogeography 21, 605-623.

Schnitzler, A., Gafta, D., Cornier, T., 2003: Concepts architecturaux et particularités écosystémiques des ripisylves. In: Piégay, H., Pautou, G., Ruffinoni, C.(eds.), Les forêts riveraines des cours deau, écologie, fonctions et gestions, 30-45. Institut pour le developpement forestier, Town?

Schnitzler, A., Hale, B. W., Alsum, E. M., 2007: Examing native and exotic species diversity in European riparian forests. Biological Conservation 138, 146-158.

Schnitzler, A., Aumaitre, D., 2008: Invasiveness and Invisibility After Change Sin Land Uses. Proceedings 12 World Lake Conférence, Jaipur, 1046-1050.

SkÁlova, H., PYŠEK, P., 2009: Germination and establishement of invasive and native Impatiens species in species-specific microsites. In: PYšEK, P., PERGL, J. (eds.), Biological Invasions: towards a Synthesis. Neobiota 8, 101-109.

Soó, R., 1963: Systematische Übersicht der pannonischen Pflanzengesellschaften, 6. Die Gebirgswälder 2. Acta Botanica Hungarica 9, 123-150.

STATSOFT, inc., 2007: STATISTICA (data analysis software system), version 8.0. www. statsoft.com.

ŠILC, U., 2003: Vegetation of the class Salicetea purpureae in Dolenjska (SE Slovenia). Fitosociologia 40, 3-27.

Tabacchi, E., Planty-Tabacchi, A.-M., Salinas, M. J., Décamps, H., 1996: Landscape structure and diversity in riparian plant communities: a longitudinal comparative study. Regulated rivers: Research \& Management 12, 367-390.

TER BraAK, J. F. C., ŠMilauer, P., 2002: CANOCO Reference Manual and CanoDraw for Windows Userž s Guide. Software for Canonical Community Ordination (version 4.5). Microcomputer Power, Ithaca.

TICHÝ, L., 2002: JUICE, software for vegetation classification. Journal of Vegetation Science 13, 451-453.

TiChÝ, L., CHYTRÝ, M., 2006: Statistical determination of diagnostic species for site groups of unequal size. Journal of Vegetation Science 17, 809-818.

Tickner, D. P., Angold, P. G., Gurnell, A. M., Mountford, J. O., 2001: Riparian plant invasions: hydrogeomorphological control and ecological impacts. Progress in Physical Geography 25, 22-52.

Turner, M. G., Gergel, S. E., Dixon, M. D., Miller, J. R., 2004: Distribution and abundance of trees in floodplain forests of the Wisconsin River: Environmental influences at different scales. Journal of Vegetation Science 15, 729-738.

Tutin, T. G., Heywood, V. H., Burges, N. A., Moore, D. M., Valentine, D. H., Walters, S. M., WebB, D. A. (eds.) 1964-1980: Flora Europaea, 1-5. Cambridge University Press, Cambridge.

Vicherek, J., Antonín, V., Danihelka, J., Grulich, V., Gruna, B., Hradílek, Z., RehoReK, V., Šumberová, K., VAmpola, P., VÁGner, A., 2000: Flora and vegetation at the confluence of the Morava and Dyje rivers (in Czech). Masarykova Univerzita v Brne, Brno. 
VUKELIĆ, J., BARIČEVIĆ, D., 2004: The association of spreading elm and narrow-leaved ash (Fraxino-Ulmetum laevis Slav. 1952) in floodplain forests of the Podravina and Podunavlje. Hacquetia 3, 49-60.

Vukelić, J., BARIČEVIĆ, D., 2005: Forest vegetation of flooded regions (in Croatian). In: Vukelić, J., Prpić, B., Kajba, B., Matić, S., Vratarić, P., Glavaš, M., Jakovac, H., Floodplain forests in Croatia (in Croatian). Akademija šumarskih znanosti, Zagreb.

Willner, W., GrabHERr, G., 2007: Die Wälder und Gebüsche Österreichs. Spektrum, Akademischer Verlag.

ZEDLER, J. B., KERCHER, S., 2004: Causes and consequences of invasive plants in wetlands: oppurtunists and outcomes. Critical Reviews in Plant Sciences 23, 431-452.

ZelenÝ, D., TichÝ, L., 2007: Species response curves in JUICE. Retrieved September 9, 2009, from http://sci.muni.cz/botany/zeleny/hof.php

ZELNIK, I., ČARNI, A., 2008: Distribution of plant communities, ecological strategy types and diversity along a moisture gradient. Community Ecology 9, 1-9. 
Acta Bot. Croat. $72(1), 97-111,2013$

CODEN: ABCRA 25

ISSN 0365-0588

eISSN $1847-8476$

DOI: $10.2478 / \mathrm{v} 10184-012-0008-6$

\title{
Population structure of woody plants in the arid cloud forests of Dhofar, southern Oman
}

\author{
MOHAMEd A. El-SHEIKH*,** \\ Department of Botany, Faculty of Science, Damanhour University, Damanhour, Egypt
}

\begin{abstract}
This study evaluates the size frequency distribution of 11 trees and shrubs in the cloud forest in Wadi Garziz, southern Oman, in order to assess their current situation, which is affected by cutting, overgrazing and other constraints. A size class distribution and a vegetation structure analysis were applied in order to analyze the dynamics of this forest using census data from 51 plots selected across 5 transects covering the hill-slope and wadi-bed habitats. Some of the trees inhabiting the hill-slopes (e.g. Acacia senegal and Commiphora spp.) were found to exhibit an inverse J-shaped distribution with constant regeneration, whilst in the wadi bed these same trees exhibited a J-shaped distribution (i.e. of declining populations). On the other hand, Acacia etbaica inhabiting the hill-slopes exhibited a tendency towards a J-shaped distribution and an inverse J-shaped distribution in the wadi-bed. All the populations (i.e. inhabiting the hill-slopes and the beds) of Anogeissus dhofarica had a J-shaped distribution whereas all the populations of Blepharispermum hirtum had a more or less inverse J-shaped distribution. The Ziziphus spina-christi and Acacia tortilis populations, meanwhile, exhibited the bi-modal shape of size distribution. The shrubs inhabiting the hill-slopes (e.g. Coroton confertus and Ormocarpum dhofarense) exhibited a tendency towards a J-shaped distribution; such distribution characterizes a declining population with a limited regenerational capacity. Overall, most of the examined populations, except those of Acacia etbaica in wadi-bed and Blepharispermum hirtum, seemed to be under stress from both environmental and human factors, particularly in the wadi bed. This type of study can provide a basis for the development of a management plan to support the conservation and sustainable use of forest vegetation in an arid region.
\end{abstract}

Key words: Cloud forest, distribution of trees, ecosystem management, seed dispersal

\section{Introduction}

Oman is situated in the latitudinal belt of subtropical deserts of the Northern Hemisphere. Water is generally considered to be the most important limiting factor for the

* Corresponding address, e-mail: el_sheikh_eg@yahoo.co.uk

**Present address: Botany and Microbiology Department, College of Science, King Saud University, P. O. Box 2455, Riyadh 11451, Saudi Arabia

Copyright ${ }^{\circledR} 2013$ by Acta Botanica Croatica, the Faculty of Science, University of Zagreb. All rights reserved. 
germination, growth and productivity of woody plants in desert ecosystems like those of Oman (BAXTER et al. 2005, ShALTOuT et al. 2009). In the forests of northern Oman, for example, FISHER and GRANDER (1995) have identified variations in the population size and regeneration of juniper woodlands as being affected by the microclimate, topography and hydrology of the area. In addition to these environmental and climatological factors, however, human activities (primarily over-grazing by livestock and related disturbances) are one of the principal influences on woodland species (OLIVER 1980, AGREN and ZACHRisson 1990, Skarpe 1990, Stewart and Rose 1990, Welden et al. 1991, Veblen 1992, SAKIO 1997, LYKKE 1998, SAKIO et al. 2002, TANAKA et al. 2008).

Even within desert regions, there may be significant local variations in water limitation. In cloud forests, for example, cloud condensation in fog-affected escarpment mountain slopes and fog precipitation during the summer season create a niche for moist woodland vegetation within the surrounding desert. In a cloud forest, woodland vegetation is able to gain enough water for survival through enhanced capture (filtering) of cloud water by tree canopies or from horizontal precipitation. This is the case in parts of the Dhofar Mountains of Oman, which are a remnant of a much more extensive moist vegetation belt, which once spread across the Arabian Peninsula (RADCLIFFE-SMith 1980).

The cloud forest of the Dhofar Mountains is classified as a centre of plant diversity in the Arabian Peninsula, with approximately 750 species, of which some 60 are endemic (RADCLIFFE-SMith 1980, MilleR 1994). Dhofar, like other areas of Oman, is developing rapidly, and this development has the potential to put the ecosystem under stress through increased human activities, such as cutting for firewood, housing, road building, and also from overgrazing. One of the features of a cloud forest is that a large proportion of total precipitation is filtered by the very presence of vegetation. Once vegetation is degraded, therefore, it becomes more difficult to re-establish due to the reduced level of filtered precipitation. Over-use of the Dhofar cloud forest has the potential, therefore, to seriously threaten this diverse ecosystem (Miller and Morris 1988, GHAZANFAR 1998).

Throughout Dhofar an urgent need exists for conservation measures and the adoption of sustainable utilization methods for keystone tree species, so that further degradation of natural resources can be avoided. This is especially the case since trees and shrubs can be of high ecological, economic and medicinal importance in arid regions (MILLER and MoRRIS 1988, ShEDED et al. 2006, BRigGs et al. 2007, ShAltout et al. 2009). Efficient management plans, however, must be based on knowledge of the current situation and the trends towards change in that situation.

The present work assessed the actual status of tree and shrub populations in the Dhofar cloud forests on the basis of static vegetation data. For this, the size structure of 11 populations of trees and shrubs in Wadi Garziz, southern Oman, were analyzed. Based on this analysis, factors affecting the survival of individuals in each population were identified and the regeneration, stability and decline status of these populations were described. The paper uses size-class distribution to consider the nature of the population changes in severely disturbed sites in the cloud forest and seeks to identify causes of population stress in order to inform subsequent population management plans.

The structure of a population of plants may be described in terms of the age and size of the population, and the form of its life stages. Since the fecundity and survival of plants are much more closely related to size than age (HARPER and WHITE 1974, HARPER 1977, WEINER 1986), some authors, e.g. (Werner and CASSwell 1977, CASSWEll 1986, Shaltout and 
Ayyad 1988, Shaltout et al. 2009) have argued that it is preferable to classify the life history of a plant by size rather than by age. Size-class distribution of trees has traditionally been employed in studies of forests specifically as an indicator of changes in species composition (ANonymous 1983, Newbery and Gartlan 1996, PoORTER et al. 1996, LyKKe 1998). A reverse J-shaped size-class distribution curve is usually characteristic of a species with good regeneration and continuous replacement, whereas distribution curves deviating from such a reverse-J shape tend to indicate a lack of recruitment and may indicate changes in species composition (HALL and BAWA 1993, LYKKE 1998).

Like all ecosystems, forests undergo changes brought about by a combination of endogenous and exogenous processes (RICHARD and DANIEL 2004). The population size structure of a woody species reflects regeneration processes and, when compared with the spatial structure of the forest, can reveal important insights regarding forest dynamics (TAKAHASH et al. 2001, Hou et al. 2004).

\section{Study area}

The study area is Wadi Garziz, $17^{\circ} 07^{\prime} 55^{\prime \prime} \mathrm{N}, 54^{\circ} 01^{\prime} 59^{\prime \prime} \mathrm{E}$, which is a part of the Dhofar region, southwest Oman. Along the southern coast, there is a range of limestone mountains covered by a woody vegetation type unique in Arabia (MILLER and MORRIS 1988). The mountains extend eastwards from the Yemen border as a crescent-shaped escarpment with a length of about $290 \mathrm{~km}$ (Fig. 1). The top of the range consists of a rolling plateau rising to over $2100 \mathrm{~m}$, dissected by deep wadis (EL-BAz 2002). There are no permanent water-courses, but pools persist in the wadi beds and a series of spring-fed pools can be found along the foot of the mountains. From June to mid-September the south-facing escarpments

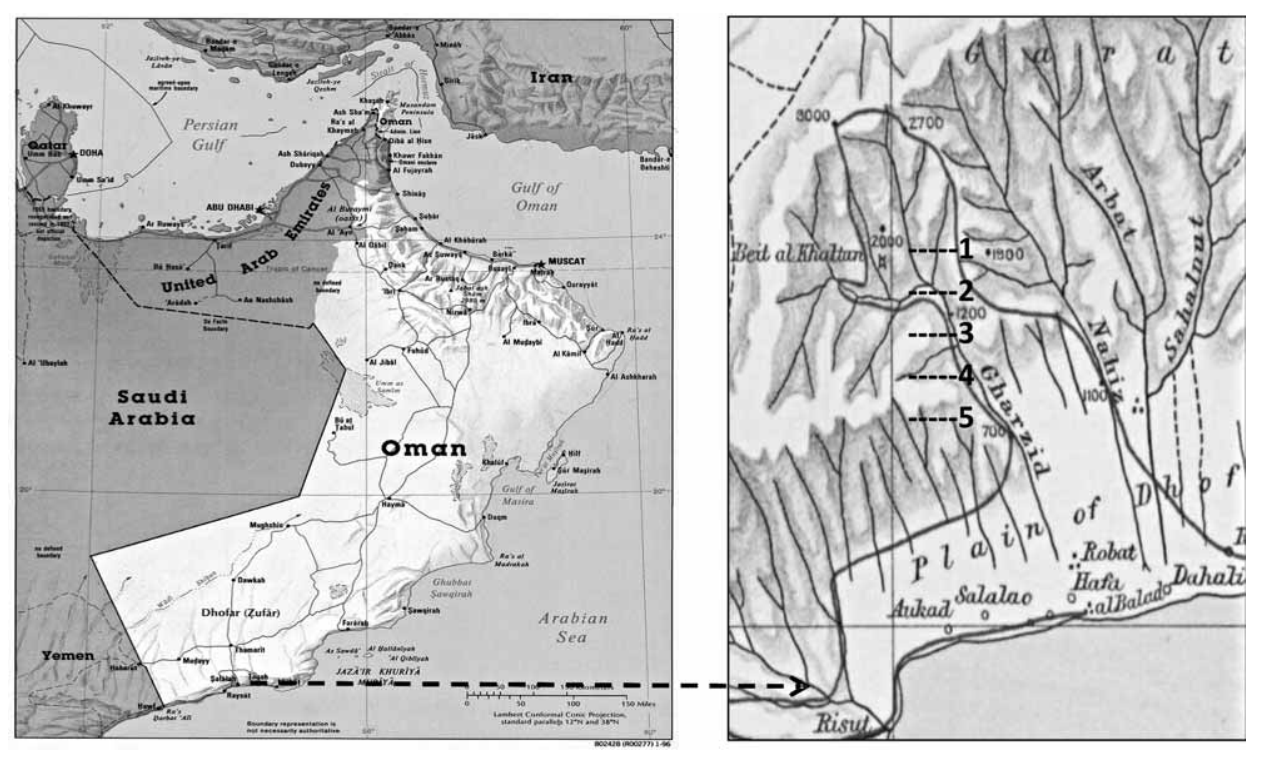

Fig. 1. Map of Oman showing the study area of Wadi Garziz (a), and a topographical map showing wadi Garziz and a part of plain of Dhofar with 5 transects (b). 
are blanketed by moisture-laden clouds, fed by southwest monsoon weather patterns (Fig. 2). Due to this, the region hosts a unique seasonally water-limited cloud forest, sustained by water droplets from the foggy clouds that condense on the plant surfaces and thence supply water to the soil. During the dry season, the trees can take up the required water from the supplemental water reserves percolated down to the ground water (RADCLIFFE-SMITH 1980, Miller and Morris 1988, HildebrandT and Eltahir 2006).

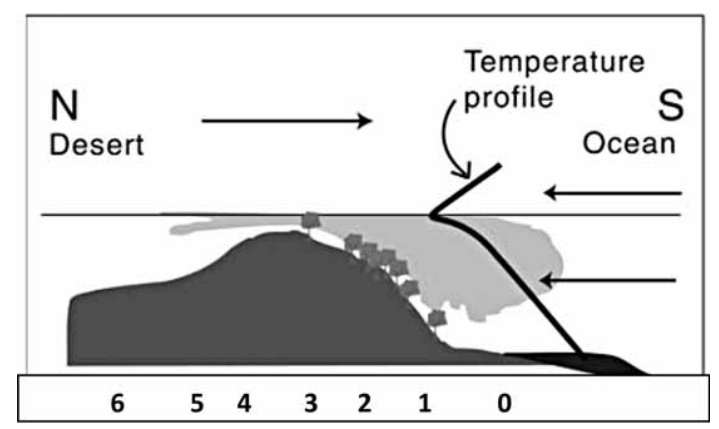

Fig. 2. Meteorological situation in Dhofar during the monsoon, and a diagrammatic representation of a section through Dhofar showing the main habitats from sea to desert: 0 - ocean, 1 coastal, 2 - foothills, 3 - escarpment, 4 - dry plateau, 5 - north cliffs, 6 - desert (modified from HILDEBRANDT et al. 2007).

Meteorological data for the region from the period 1942-1972 (SALE 1980) indicate that mean temperatures at the coastal plain of Salalah reach a high of $32{ }^{\circ} \mathrm{C}$ in May and June, and a low of $27^{\circ} \mathrm{C}$ in January and February. The highest relative humidity (97\%) is in July and August during the period of monsoon currents, and the lowest (40\%) is in February. Unfortunately no data from continuous measurements are available for the mountains. However, at 'Qayrun Heriti' village, near the mountain, the total rainfall during the monsoon season is more than $200 \mathrm{~mm}$ in June, July and August (Fig. 3) (ANONYMOus 2004). The soil of the wadi beds is alluvial with fine particles (EL-BAZ 2002).

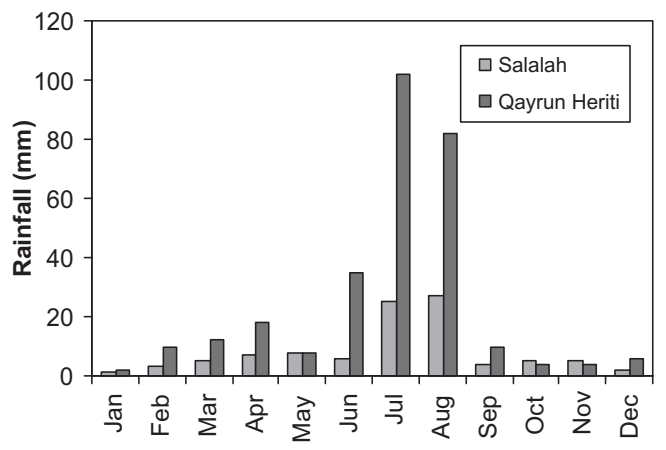

Fig. 3. Mean rainfall (in mm) in Salalah (elevation: $25 \mathrm{~m}$ ) and the mountain village 'Qayrun Heriti' (elevation: $880 \mathrm{~m}$ a.s.1.). 


\section{Materials and methods}

A field survey was carried out in the western slope (600-1200 $\mathrm{m}$ a.s.1.) and the wadi-bed (500-600 m a.s.1.) of Wadi Garziz. The study was carried out during winter in 2007 after the monsoon season. Five W-E transects were established in the study area (Fig. 1a and b) and 51 plots of $20 \times 20 \mathrm{~m}$ size were selected ( 27 plots on the hill-slope and 24 on wadi-bed) with the variation in the number of plots depending on the habitat heterogeneity. In each plot eleven taxa of trees and shrubs of the cloud forest were sampled (Tab. 1). These species were selected as they are the most common species, they are native and endemic woody species and constitute the main body of the forest, which is under severe anthropogenic disturbances. These species were identified according to MILLER and MoRRIS (1988) and

Tab. 1. Characteristics of the sampled species in Wadi Gerziz, Oman showing their families and dispersal type. Endemic species according to (MILLER and MORRIS 1988) are in bold.

\begin{tabular}{|c|c|c|}
\hline Species & Family & Dispersal type \\
\hline \multicolumn{3}{|l|}{ TREES } \\
\hline Acacia tortilis (Forssk.) Hayne & Fabaceae & Fruit legume, Seed 6 mm 'Ballochore' \\
\hline Acacia etbaica Schweinf. & Fabaceae & Fruit legume, Seed 6 mm 'Ballochore' \\
\hline Acacia senegal Willd. & Fabaceae & Fruit legume, Seed 6 mm 'Ballochore' \\
\hline Anogeissus dhofarica A. J. Scott & Combretaceae & Two winged 'Pterochore' \\
\hline Blepharispermum hirtum Oliv. & Asteraceae & With pappus and bristle 'Pogonochore' \\
\hline Commiphora habessinica (Berg.) Engl. & Burseraceae & Drupe $9 \mathrm{~mm}$ 'Sarcochore' \\
\hline Commiphora gileadensis (L.) C. Christ & Burseraceae & Drupe 8 mm 'Sarcochore' \\
\hline Ziziphus spina-christi (L.) Willd. & Rhamnaceae & Drupe 1cm, Seed 5 mm 'Sarcochore' \\
\hline \multicolumn{3}{|l|}{ SHRUBS } \\
\hline Croton confertus Baker & Euphorbiaceae & Capsule with hairs, seed $7 \mathrm{~mm}$ 'Desmochore' \\
\hline Ormocarpum dhofarense Hillcoat et Gillett & Fabaceae & Legume 'Ballochore' \\
\hline Sideroxylon mascatense (Falc.) A. DC. & Sapotaceae & Berry 15 mm 'Sarcochore' \\
\hline
\end{tabular}

include eight trees (Acacia tortilis, Acacia etbaica, Acacia senegal, Anogeissus dhofarica, Commiphora habessinica, Commiphora gileadensis, Blepharispermum hirtum and Ziziphus spina-christi) and three shrubs (Croton confertus, Ormocarpum dhofarense and Sideroxylon mascatense). Seed and fruit dispersal types were described according to the scheme of DANSEREAU and LEMS (1957), which distinguishes dispersal types primarily according to the morphology of the diaspore. The seed dispersal types recognized in the present study are: ballochore: parent plant with a mechanism for diaspore expulsion; sarcochore: diaspore with juicy or fleshy outer layer; pterochore: diaspore with scarious winglike appendages; desmochore: diaspore with short, stiff or hooked appendages; and pogonochore: with long hair-like appendages. The species dispersal frequency was calculated in each plot; the ratio between the number of individuals of the species and number of individuals of all species of dispersal types in the habitat. Impacts of human activities such as cutting, firing, grazing and resultant gaps were recorded in each plot.

In the concerned plot, the height $(\mathrm{H})$ and mean crown diameter (CD: based on three crown diameters depending on the uniformity of the measured individual) of each indi- 
vidual belonging a certain species were measured $(\mathrm{cm})$. Species size index was calculated as: H+CD)/2 (modified from CRISP and LANGE 1976, by ShalTout et al. 2003). The size index values of each species were used to determine the frequency distribution of the different age (size) cohorts. In order to evaluate the characteristics of each size class, the total density of the plant species per ha was also calculated. Mean and coefficient of variation of density, height, crown diameter and size index of each species were calculated.

\section{Results}

\section{Vegetation structure}

In the vegetation of Wadi Garziz, Acacia species represented the greatest proportion of the dominant family Fabaceae, followed by Burseraceae species (Tab. 1). Concerning seed and fruit dispersals, pogonochore (e.g. Blepharispermum hirtum) species, which depend on wind dispersal, attained the highest individual density in the study area, followed by sarcochorous species that usually depend on dispersal by animals (Fig. 4). Because of the human impact, the cloud forest is a disturbed environment, the wadi-bed more so than the hill-slope (Fig. 5).

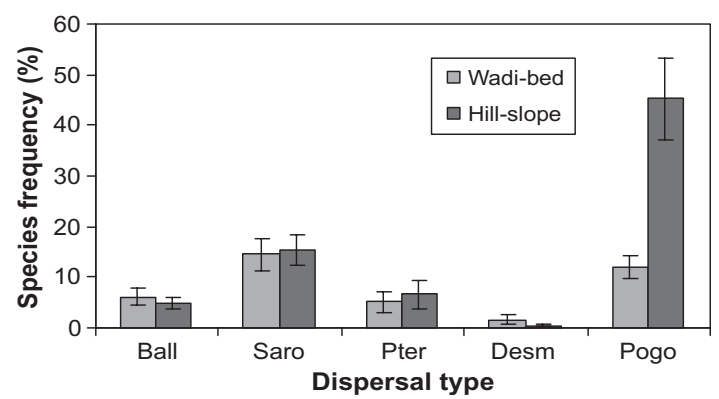

Fig. 4. The relative species dispersal frequency in the two habitats of cloud forests. Ball - Ballochore, Saro - Sarochore, Pter - Pterochore, Desm - Desmochore, Pogo - Pogonochore.

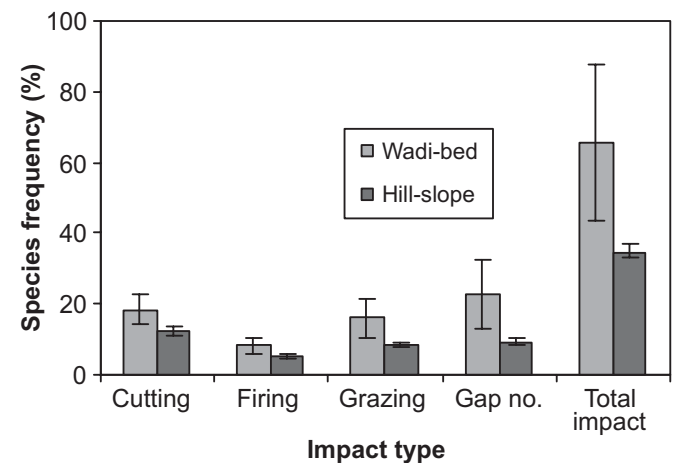

Fig. 5. Frequency of the human impact types (\%) in the two habitats of cloud forests. 
Acacia etbaica exhibited twice as many individuals per hectare in the wadi-bed area (105 individuals $\mathrm{ha}^{-1}$ ) as on the hill-slopes (53 individuals $\mathrm{ha}^{-1}$ ). On the other hand, the density of most other taxa was distinctly higher on the slope plots. Sometimes, they were exclusively present on slope plots. The trees Acacia tortilis and Ziziphus spina-christi, however, exhibited almost the same density of individuals at the hill-slope and the wadi-bed sites (Tab. 2). The highest density of occurrence (398 ind./ha) was found in the Blepharispermum hirtum population, followed by that of Commiphora gileadensis established on the hill-slope, while the population of Ormocarpum dhofarense showed the lowest density (67 individuals $\mathrm{ha}^{-1}$ ), being found exclusively on the hill-slopes. The height of most tree species exceeded five metres. In most cases relationships between the individual crown diameter and the height of the 11 studied species are simple linear with $\mathrm{r}$ values $>0.7$ except for »Sideroxylon mascatense and Ormocarpum dhofarense«. The mean height/crown diameter ratio is $>1.0$ for all species (Tab. 2)

Tab. 2. Mean values of some demographic variables of the common shrubs and trees in Wadi Gerziz, Oman. B: Wadi-bed, S: Wadi slope, H: Height and CD: Crown Diameter.

\begin{tabular}{|c|c|c|c|c|c|c|c|}
\hline \multirow{2}{*}{ Species } & \multicolumn{2}{|c|}{$\begin{array}{l}\text { Density } \\
\left(\text { ind ha }^{-1}\right)\end{array}$} & \multirow{2}{*}{$\begin{array}{l}\text { Height } \\
(\mathrm{cm})\end{array}$} & \multirow{2}{*}{$\begin{array}{l}\text { Crown } \\
\text { diameter } \\
(\mathrm{cm})\end{array}$} & \multirow{2}{*}{$\mathrm{H}: \mathrm{CD}$} & \multirow{2}{*}{$\begin{array}{c}\text { Size class } \\
\text { index } \\
(\mathrm{cm})\end{array}$} & \multirow{2}{*}{$\begin{array}{c}\text { r-value } \\
\text { between } \\
\mathrm{H} \text { and CD }\end{array}$} \\
\hline & $\mathrm{S}$ & $\mathrm{B}$ & & & & & \\
\hline \multicolumn{8}{|l|}{ Trees } \\
\hline Acacia tortilis & 117 & 106 & 538 & 341 & 1.57 & 440 & 0.89 \\
\hline Acacia etbaica & 53 & 105 & 413 & 281 & 1.47 & 348 & 0.92 \\
\hline Acacia senegal & 303 & 116 & 522 & 376 & 1.38 & 450 & 0.86 \\
\hline Anogeissus dhofarica & 194 & 139 & 680 & 462 & 1.47 & 572 & 0.79 \\
\hline Blepharispermum hirtum & 398 & 170 & 296 & 163 & 1.81 & 230 & 0.88 \\
\hline Commiphora habessinica & 130 & 35 & 154 & 100 & 1.53 & 127 & 0.89 \\
\hline Commiphora gileadensis & 311 & - & 72 & 18 & 3.90 & 45 & 0.97 \\
\hline Ziziphus spina-christi & 147 & 133 & 568 & 396 & 1.43 & 482 & 0.88 \\
\hline \multicolumn{8}{|l|}{ Shrubs } \\
\hline Croton confertus & 258 & - & 592 & 393 & 1.50 & 493 & 0.82 \\
\hline Ormocarpum dhofarense & 67 & - & 210 & 179 & 1.17 & 195 & 0.69 \\
\hline Sideroxylon mascatense & 215 & - & 145 & 75 & 1.94 & 110 & 0.27 \\
\hline
\end{tabular}

\section{Population size classes frequency distribution}

The size class frequency distribution of some trees inhabiting the hill-slopes (e.g. Acacia senegal and Commiphora spp.) showed an inverse J-shaped distribution, while they attained a J-shaped distribution in the wadi-bed populations (Fig. 6). On the other hand, Acacia etbaica inhabiting the hill-slopes demonstrated a J-shaped distribution, while in the wadi-bed it showed an inverse J-shaped distribution. The entire populations (i.e. inhabiting both of the hill-slopes and wadi-beds) of Anogeissus dhofarica attained a J-shaped distribution, whereas all the populations of Blepharispermum hirtum had more or less an inverse J-shaped or positively skewed size frequency distribution. Meanwhile, all the populations of Ziziphus spina-christi and Acacia tortilis exhibited a bi-modal shaped size frequency distribution. 


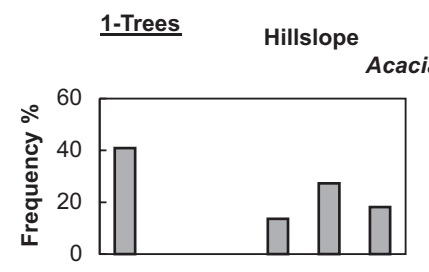

Bed

1-Trees

Hillslope

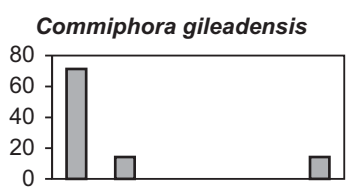

2-Shrubs
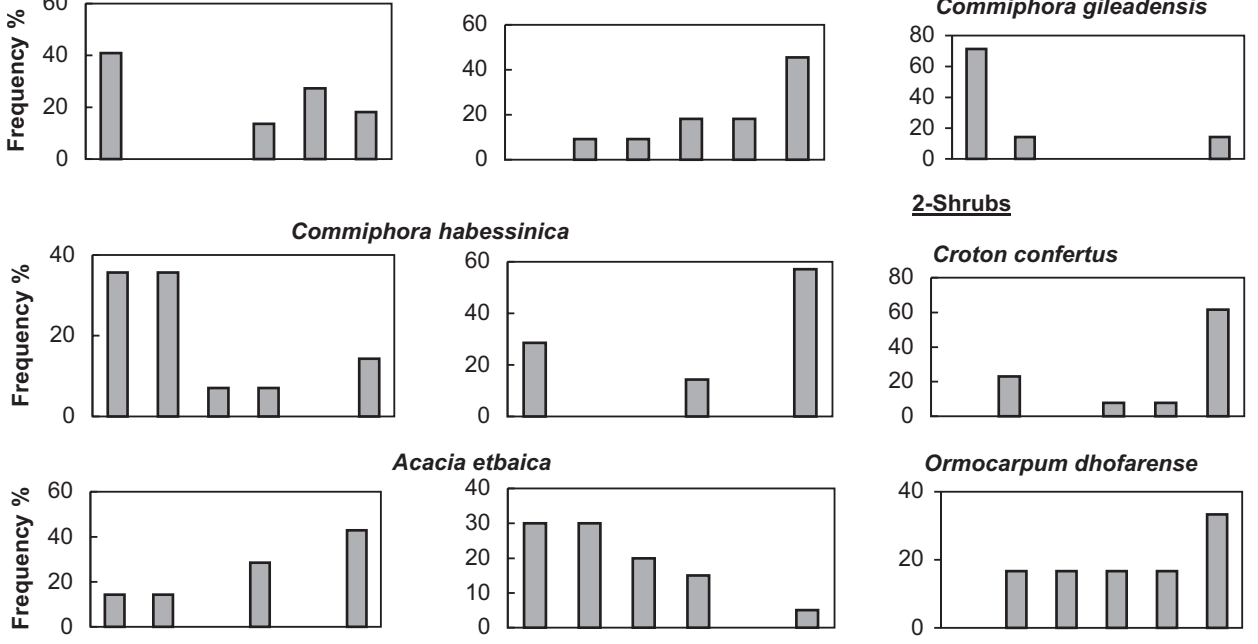

Acacia etbaica
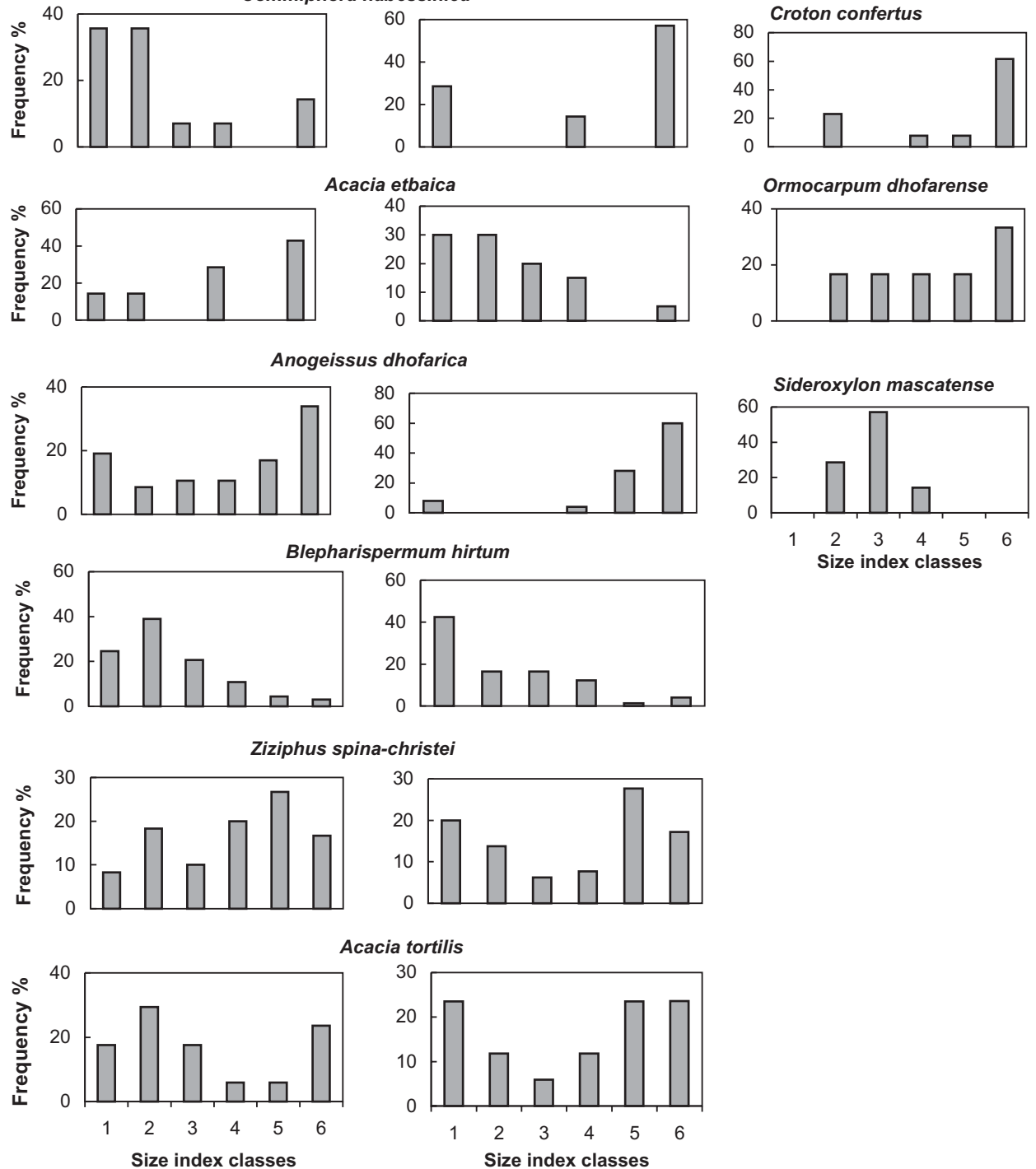

Acacia tortilis

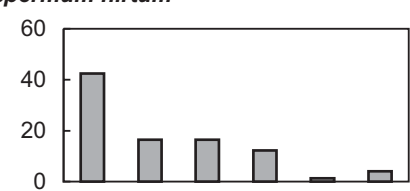

Size index classes

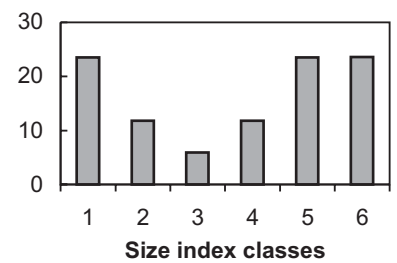

Fig. 6. Size-frequency distribution of the 11 common woody populations in the Dhofar region of Oman. The ranges of size index classes are as follows: for 8 trees are $1=<100,2=100-250$, $3=250-400,4=400-550,5=550-700$ and $6=>700$. For the 3 shrubs are $1=<50,2=50-100$, $3=100-150,4=150-200,5=200-250$, and $6=>250 \mathrm{~cm}$. 
The shrubs inhabiting the hill-slopes (e.g. Coroton confertus and Ormocarpum dhofarense) have a tendency towards the J-shaped distribution while Sideroxylon mascatense population showed a bell-shaped distribution. (Fig. 5).

\section{Discussion}

The size differences in plant populations revealed in this study may be caused directly or through differences in growth rates due to age differences, genetic variation, heterogeneity of resources, competition and herbivory (WEINER 1985). As reported by GRAY (1975), the topography and relative abundance of plants with a dense crown, along with the frequency and abundance of rainfall and human impacts are among the important variables to be accounted for in an attempt to quantify the capacity of species for regeneration. Human impact in forest environments frequently leads to vegetation changes that take place faster than natural vegetation transformations, as human impact-caused disturbances often occur in the form of continuous and widespread stress, e.g. cutting, frequent fires, grazing, and construction of roads and buildings. In environments where population changes are significant, the impact of population change on vegetation structure might override other demographic parameters (LYKKE 1998). This discussion will consider the significance of the population changes in the species surveyed in this study.

Populations of Acacia senegal, Commiphora spp. and Blepharispermum hirtum showed a greater density with a size distribution positively skewed or an inverse J-shaped size distribution towards the smaller individuals on the hill-slope as compared to the wadi-bed. The pattern of distribution of these species may represent rapidly growing populations with high reproductive capacity. While such distributions would tend to suggest a high level of juvenile mortality (HARPER 1977, EL-SHEIKH 2005), this does not contra-indicate long-term population stability, since in most stable populations one would expect excess juveniles over mature individuals (CRISP and LANGE 1976, GOLDBERG and TURNER 1986, SHALTOUT and AYYAD 1988, EL-SHEIKH 2005).

If human activities increase in the hill-slope areas, however, small individuals will inevitably die before maturity (LYKKE 1998). This is well demonstrated by the Commiphora spp., for example, which occurred in greater densities on the hill-slope than in the wadi-bed. Whereas the steeper and less accessible hill-slopes tended to exhibit fewer signs of human activity, Commiphora spp. in the wadi-bed appeared subject to over-cutting by natives on account of its aromatic secretions, which are used in folk medicine (BATANOUNY 1987, MiLLER 1994).

A further advantage provided by the steep hill-slopes was that the tree crowns were generally arranged in a step-like fashion and tended to be asymmetrical. This imbricate arrangement allowed more sunlight to penetrate from all sides and enabled individual densities to increase through creating different microhabitats and therefore greater heterogeneity in the substrate (WEISSENHOFER 2005).

Turning now to the endemic shrub Ormocarpum dhofarense, this species demonstrated a lower density and a J-shaped size distribution on the hill-slopes and disappeared totally from wadi-bed. The Ormocarpum dhofarense shrubs were particularly vulnerable to human impact in the wadi-bed, e.g. through overgrazing due to the palatability of this plant, its 
edible fruits, and cutting for folk medicine, firing and construction materials. Moreover, on the hill-slopes, the presence of tall trees represented a limiting factor for the shrubs with a negative influence on individual density. Therefore, overall, Ormocarpum dhofarense was found to be suffering from poor regeneration and insufficient seed dispersal »ballochorous « (WEISSENHOFER 2005).

Among the regional endemic species Blepharispermum hirtum had the highest density in the study area with an inverse J-shaped distribution. This may be because it has minute pogonochores for seed dispersal that allow dispersal by wind distribution. Consequently the seeds of the plant are able to invade large areas, including those less used by human inhabitants. This suggests that micro-environmental sites are suitable for their establishment, growth and survival (GRIME 1979; GREEN and JOHNSON 1996; WANG et al. 1999, 2000; MANABE et al. 2000; Hou, et al. 2004; El-SHEIKH 2005).

On the other hand, only Acacia etbaica, had a wide range of occurrence positively skewed towards small individuals in the wadi-bed rather than the hill-slope. This plant has a higher water demand than other Acacia spp. It tends to proliferate in open environments such as hillsides and the mouths of wadi openings (delta) with deep alluvial soils that receive seasonal flood waters (BATANOUNY 1987, MiLLER 1994, FETENE 2003). Wadi mouths store a significant amount of shallow groundwater where seepage of moisture and runoff collect from the hill-slopes (Miller and Morris 1988, HildEBRANDT and ElTAHIR 2006). Moreover, the ground surface of this habitat is covered with conglomerates and boulders which decrease evaporation and provide shelter for saplings. Acacia etbaica also has a hard stem nature to encroacher overgrazing and has a capacity to recover these degraded sites following enclosures of a few years (FETENE 2003). Field observation confirmed that this plant is able to regenerate following significant disturbance, such as cutting and overgrazing - events which also lead to a clumped distribution of young trees around older mother trees, as well as re-sprouting from dormant stems. Overall, Acacia etbaica ability for vigorous regeneration is a strategy well adapted to the environmental disturbance which is common in the contemporary cloud forest.

The entire population of Acacia tortilis and Ziziphus spina-christi had the same density and bi-modal bell shaped size distribution, which tends to indicate a comparable proportion of juvenile and mature individuals. If the current situation continues, however, the bimodal size distribution would tend to predict a reduction in the population size of this species in the future (Shaltout and Mady 1993, Al-SodAny 2003, El-SheikH 2005). This distribution might have resulted from an initially unimodal size distribution with a discontinuous variation in exponential growth rates among individuals. Sources of discontinuous variation may be due to environmental heterogeneity, gaps, variations in pedo-topography, altitude, impact gradients, undulation, light and soil conditions. It is known that the size structure of some species decreases with increasing undulation and decreasing soil depth (TAKAHASHI 1994, Pelissier and Goreaud 2001, Nishimura and Kohyama 2002). In addition, fluctuation in the availability of water from the short, wet, monsoon season to the long dry season may cause a variable input of new seedlings to the population each year (SHALTOUT and AYYAD 1988). Regarding the gaps, once vegetation is degraded, it becomes more difficult to re-establish due to a reduced level of filtered precipitation by trees, which creates an unbalance in the availability of water (HUSTON 1986, GHAZANFAR 1998, MASAKI et al. 1992, 
TANAKA et al. 2008). Moreover, mature trees change the conditions within their own microsite, which affects the establishment of the same or other species (WILSON and AGNEW 1992) and thus the distribution of saplings is spatially associated with canopy crowns (either conspecific or heterospecific). Some sapling distributions overlap mature trees of the other species along complex environmental gradients (STOHLGREN et al. 1998).

The dominance of Acacia species (as opposed to open canopy species) in the Dhofar forests is reflective of their ability to survive and succeed in such adverse conditions combining long dry periods and increasing human activities. In particular it is recognised that the acacia's ability to utilise dormancy as a means of avoiding climatic stress is of great importance in allowing the colonization of habitats unfavourable for growth at certain times of the year (MAHMOUD 1977). In addition, the performance and vigour of acacia trees, as indicated by the density and size of individuals, is known to differ according to the type of habitat, altitude, relative ground water content in dry periods, and human activities (MAHMOUd 1977, BATANOUNy 1987, FetENE 2003). Moreover, acacias are able to increase as the main encroacher in overgrazed habitats due to their large shallow lateral roots. ToLSMA et al. (1987) and SKARPE (1990) attribute the success of shallow-rooted acacias as compared to deep rooted species in encroaching overgrazed areas to their better access to nutrients, including nitrogen fixation by Rhizobium. This is probably of particular significance in a nutrient poor environment, such as a wadi-bed, but access to water is likely to be at least as important. Therefore, the increase of Acacia spp. in the cloud forest may give a good indication of the progress of wider vegetation changes that occur in the disturbed sites of this forest, from a wet closed forest habitat to more open dry savanna conditions. This steady replacement of the common and endemic woody trees and shrubs typical of the wet cloud forest is well illustrated by the case of Anogeissus dhofarica (a closed canopy species) which exhibited a J-shaped distribution towards larger individuals in all habitats of the wadi, tending to indicate a declining population with limited regeneration capacity or higher mortality of young individuals. (NARUKAWA and YAMAMOTO 2002, EL-SHEIKH 2005, COOMES and Allen 2007, TANAKA et al. 2008).

In conclusion, most of the studied woody trees and shrubs in the cloud forest, especially in the wadi-bed site, have been facing many stresses from human activities in southern Oman during the past 40 years, due to modernization and road construction inside this natural cloud forest. Some of these studied populations are the endemic species Anogeissus dhofarica, Maytenus dhofariensis, Ormocarpum dhofarense and it is these that are considered to be among the most threatened species in the cloud forest of Dhofar region due to their widespread collection for fodder, medicine, buildings and firewood (MILLER and Morris 1988, GHAZANFAR 1998, BRINKMANN et al. 2009). In general, different types of human impacts, mainly obvious, cause degradation in the cloud forest in Wadi Garziz. The size structure frequencies of these woody species give a good indication of the vegetation changes consequent to this human activity and further indicate that these are occurring especially in the wadi-bed, which seems to be experiencing a greater level of disturbance than the hill-slope areas, with a number of threatened species. This information on species distributions and threats is important for formulating management plans, and the size-class assessment method can be recommended for use in disturbed environments where changes are occurring quickly and where environmental management plans are therefore needed urgently. 


\section{Acknowledgements}

I would thank Prof. Loutfy Boulos Botany Department, Faculty of Science, Alexandria University, Prof. K. H. Shaltout, Botany Department, Faculty of Science, Tanta University and Prof. A. K. Hegazy, Botany and Microbiology Department, College of Science, King Saud University for valuable comments. I also thank Distinguished Scientist Fellowship Program of King Saud University and Mr Karl Woodgett for assistance in proof reading a draft of this article.

\section{References}

Agren, J., ZaCKRISSON, O., 1990: Age and size structure of Pinus sylverstris populations on mires in central and northern Sweden. Journal of Ecology 78, 1049-1062.

Al-SodAnY, Y. M., 2003: Size structure and dynamics of the common shrubs in Omayed Biosphere Reserve in the western Mediterranean coast of Egypt. Ecologia Mediterranea 29, 39-48.

ANONYMOUS, 1983: Ecosystem forestiers tropicaux d'Afrique. ORSTOM-UNESCO, Paris.

AnONymous, 2004: Water resources in Sultanate of Oman. Ministry of Regional Municipalities, Environment and Water resources, Muscut, Sultanate of Oman.

Batanouny, K. H., 1987. Current knowledge of plant ecology in the Arab Gulf countries. Catena 14, 291-316.

BAXTER, W. J., GetZ, M., WAYne, P., 2005: A model-farmed evaluation of elephant effects on tree, fire dynamics in Africa savannas. Ecological Application 154, 1331-1341.

Briggs, J. M., SchaAfsma, H. D., Trenkov, D., 2007: Woody vegetation expansion in a desert grassland: Prehistoric human impact? Journal of Arid Environments 69, 458-472.

Brinkmann, K., Pazelt, A., Dickhoefer, U., Schlecht, E., Buerkert, A., 2009: Vegetation patterns and diversity along an altitudinal and grazing gradient in the Jabal al Akhdar mountain range of northern Oman. Journal of Arid Environments 73, 1035-1045.

CAsswell, H., 1986: Life cycle models for plants. Lectures on Mathematics in the Life Sciences 18, 171-233.

Coomes, D. A., Allen, R. B., 2007: Mortality and tree size distributions in natural mixed-age forests. Journal of Ecology 95, 27-40.

CRISP, M. D., LANGE, R. T., 1976: Age structure, distribution and survival under grazing of the arid-zone shrub Acacia burkitii. Oikos 27, 86-92.

DANSEREAU, P., LEMS, K., 1957: The grading of dispersal types in plant communities and their ecological significance. Contributions de L'Institute Botanique Institute of Botany, University of Montreal 71, 1-52.

EL-BAz, F., 2002: Wadis of Oman satellite image atlas. Center for Remote Sensing, Boston University; Office of the Advisor to His Majesty the Sultan for Cultural Affairs Publishing, Muscut, Sultanate of Oman.

EL-SheIKH, M. A., 2005: Plant succession on abandoned fields after 25 years of shifting cultivation in Assuit, Egypt. Journal of Arid Environments 61, 461-481.

FETENE, M., 2003: Intra-and inter-specific composition between seedlings of Acacia etbaica and a perennial grass (Hyparrenia hirta). Journal of Arid Environments 55, 441-451. 
Fisher, M., GARDNER, A., 1995: The status and ecology of a Juniperus excelsa subsp. polycarpos woodland in the northern mountains of Oman. Vegetatio 119, 33-51.

GHAZANFAR, S., 1998: Status of the flora and plant conservation in the Sultanate of Oman. Biological Conservation 85, 287-295.

GoldBerG, D. E., Turner, R. M., 1986: Vegetation change and plant demography in permanent plots in the Sonoran desert. Ecology 67, 695-712.

GrAY, B., 1975: Size-composition and regeneration of Araucaria stands in New Guinea. Journal of Ecology 63, 273-289.

GreEn, D. F., Johnson, E. A., 1996: Wind dispersal of seeds from a forest into a clearing. Ecology 82, 595-609.

GRIME, J. P., 1979: Plant strategies and vegetation processes. Wiley, New York.

HALL, P., BAWA, K., 1993: Methods to assess the impact of extraction of non-timber tropical forest products on plant populations. Economic Botany 47, 234-247.

Harper, J. L., White, J., 1974: The demography of plants. Annual Review of Ecology Evolution and Systematics 5, 419-463.

HARPER, J. L., 1977: Population biology of plants. Academic Press, London.

Hildebrandt, A., Eltahir, E. A. B., 2006: Forest on the edge: Seasonal cloud forest in Oman creates its own ecological niche. Geophysical Research Letter 33, L11401.

Hildebrandt, A., Al Aufi, M., Amerjeed, M., Shammas, M., Eltahir, E. A. B., 2007. Ecohydrology of a seasonal cloud forest in Dhofar: 1. Field experiment. Water Resources Research 43, W10411.

Hou, J. H, Mi, X. C., LiU, C. R., MA, K. P., 2004: Spatial patterns and associations in a Quercus-Betula forest in North China. Journal of Vegetation Science 15, 407-414.

Huston, M., 1986: Size bimodality in plant populations: an alternative hypothesis. Ecology 67, 265-269.

LYKKE, A. M., 1998: Assessment of species composition change in savanna vegetation by means of woody plant's size class distributions and local information. Biodiversity and Conservation 7, 1261-1275.

Mahmoud, A., 1977: Germination of three desert Acacias in relation to their survival in arid environment. Proceedings 1 Conference of Saudi Biological Society, Riyadh, 47-94.

Manabe, T., Nishimura, N., Miura, M., Yamamoto, S., 2000: Population structure and spatial patterns for trees in a temperate old-growth evergreen broad-leaved forest in Japan. Plant Ecology 151, 181-197.

Masaki, T., Suzuki, W., Niryama, K., Iida, S., Tanaka, H., Nakashizuka, T., 1992: Community structure of a species rich temperate forest, Ogawa Forest Reserve, central Japan. Vegetatio 98, 97-111.

Miller, A. G., Morris, M., 1988: Plants of Dhofar, the southern region of Oman: Traditional, Economic and Medicinal uses. Office of the Adviser for Conservation of the Environment, Diwan of Royal Court Sultanate of Oman Publishing, Sultanate of Oman.

Miller, G. M., 1994: Dhofar Fog Oasis, Oman and Yemen. In: Davis, S. D., HeYwood, V. H., Hamilton, A. C. (Eds.), Centres of plant diversity, 1, 309-311. World Wildlife Fund, International Union for Conservation of Nature, Gland. 
Newbery, D. McC., Gartlan, J. S., 1996: A structural analysis of rain forest at Korup and Douala-Edea, Cameroon. Proceedings of the Royal Society of Edinburgh 104B, 177224.

Nishimura, T. B., Kohyama, T., 2002: Formation and maintenance of community boundaries in a sub-alpine forest landscape in northern Japan. Journal of Vegetation Science13, $555-564$.

NARUKAWA, Y., Yамамото, S., 2002: Effects of dwarf bamboo (Sasa sp.) and forest floor microsites on conifer seedling recruitment in a subalpine forest, Japan. Forest Ecology and Management 163, 61-70.

OLIVER, C. D., 1980: Forest development in North America following major disturbances. Forest Ecology and Management 3, 153-168.

Poorter, L., Bongers, F., van Rompaey, R. S. A. R., De Klerk, M., 1996: Regeneration of canopy tree species at five sites in west African moist forest. Forest Ecology and Management 84, 61-69.

Pelissier, R., GoREAUd, F., 2001: A practical approach to the study of spatial structure in simple cases of heterogeneous vegetation. Journal of Vegetation Science 12, 99-108.

RICHARD, B., DANIEL, M., 2004: Advances in spatial, individual-based modeling of forest dynamics. Journal of Vegetation Science 15, 831-842.

RAdCliffe-Smith, A., 1980: The vegetation of Dhofar. in: Scientific Results of the Oman Flora and Fauna survey 1977 (Dhofar). The Journal of Oman Studies, Special Issue 2, 59-86.

Sale, J. B., 1980: The environment of the mountain region of Dhofar. Scientific results of the Oman flora and fauna survey 1977 (Dhofar). The Journal of Oman Studies 2, 17-23.

SAKIO, H., 1997: Effects of natural disturbance on the regeneration of riparian forests in a Chichibu Mountains, central Japan. Plant Ecology 132, 181-195.

Sakio, H., Kubo, M., Shimano, K., Ohno, K., 2002: Coexistence of three canopy tree species in a riparian forest in the Chichibu Mountains, central Japan. Folia Geobotanica $37,45-61$.

Shaltout, K. H., AyYAD, M. A., 1988: Structure and standing crop of Egyptian Thymelaea hirsuta populations. Vegetatio 47, 137-142.

Shaltout, K. H., MAdy, M. A., 1993: Current situation of the raudha's woody plant populations in the Central Saudi Arabia. Feddes Repertorium 104, 503-509.

Shaltout, K. H., Sheded, M. G., El-Kady, H. F., Al-Sodany, Y. M., 2003: Phytosociology and size structure of Nitraria retusa along the Egyptian Red Sea coast. Journal of Arid Environments 53, 331-345.

Shaltout, K, Sheded, M. G., SAlem, A. H., 2009: Population structure of common shrubs and trees in Wadi Allaqi Biosphere Reserve, South-East Egypt. Feddes Repertorium $120,343-354$.

Sheded, M. G. Pulford, I. D., Hamed, A. I., 2006: Presence of major and trace elements in seven medicinal plants growing in the South Eastern Desert, Egypt. Journal of Arid Environments 66, 210-217.

SKARPE, C., 1990: Structure of woody vegetation in disturbed and undisturbed arid savanna, Botswana. Vegetatio 78, 11-18. 
Stewart, G. H., Rose, A. B., 1990: The significance of life history strategies in the development history of mixed beech (Nothofagus) forests, New Zealand. Vegetatio 87, 101-114.

Stohlgren, T. J., Backand, R. R., OnAmi, Y., Binkley, D., 1998: Species-environment relationships and vegetation patterns: effects of spatial scale and tree life-stage. Plant Ecology 135, 215-229.

TAKAHASHI, K., 1994: Effect of size structure, forest floor type and disturbance regime on tree species composition in a coniferous forest in Japan, Journal of Ecology 82, 769-773.

Takahashi, K. Homma, K., Vetrova, V. B., Florenzev, S., Hara, T., 2001: Stand structure and regeneration in a Kamchatka mixed boreal forest. Journal of Vegetation Science 12, $627-634$.

Tanaka, H., Shibata, M., Masaki, T., Iida, S., Nityama, K., Abe, S., Kominami, Y., NaKaSHIZUKA, T., 2008: Comparative demography of three coexisting Acer species in gaps and under closed canopy. Journal of Vegetation Science 19, 127-138.

Tolsma, D. L., ERnst, W. H. O., VerweiJ, R. A., VooiJst, R., 1987: Seasonal variation of nutrient concentrations in a semi-arid savanna ecosystem in Botswana. Journal of Ecology 75, 755-770.

Veblen, T. T., 1992: Regeneration dynamics. In: Glenn-Lewin, D. C. Peet, R. K., Veblen, T. T. (eds), Plant succession: theory and prediction, 152-187. Chapman and Hill, London.

WANG, W., MA, K. P., LiU, C. R., 1999: Removal and predation of Quercus Liaotungensis acorns by animals. Ecological Research 14, 225-232.

Wang, W., MA, K. P., LIU, C. R., 2000: Seed shadow of Quercus Liaotungensis Koidz. in a broad-leaved deciduous forest in Dongling Mountain. Acta Botanica Sinica 42, 195202.

Werner, P. A., CAsswell, H., 1977: Population growth rates vs. stage distribution models for teasel (Dipsacus sylvestris Huds.). Ecology 58, 1103-1111.

WeINER, J., 1985: Size hierarchies in experimental populations of annual plants. Ecology 66, 746-752.

WeINER, J., 1986: How competition for light and nutrients affects size variability in Ipomoea tricolor populations. Ecology 67, 1425-1427.

Welden, C. W, Hewett, S. W., Hubbell, P. S., Foster, R. B., 1991: Sapling survival, growth, and recruitment: relationship to canopy height in a neotropical forest. Ecology $72,35-50$.

Weissenhofer, M. A., 2005: Structure and vegetation dynamics of four selected one hectare forest plots in the lowland rain forests of the Piedras Blancas National Park, Costa Rica, with notes on the vegetation diversity of the Golfo Dulce region. Ph.D. Thesis, University of Wienna.

Wilson, J. B., Agnew, A. D. Q., 1992: Positive-feedback switches in plant communities. Advances in Ecological Research 23, 263-336. 


\title{
Heaths with dwarf ericaceous shrubs and Alpine juniper (Juniperus alpina) in the Dinaric Alps: A nomenclatorial and synsystematic re-appraisal
}

\author{
BOŠTJAN SURINA ${ }^{1,2, *}$ \\ ${ }^{1}$ University of Primorska, Faculty of Mathematics, Natural Sciences and Information \\ Technologies, Glagoljaška 8, SI-6000 Koper, Slovenia \\ 2 Natural History Museum Rijeka, Lorenzov prolaz 1, 51000 Rijeka, Croatia
}

\begin{abstract}
The ecology and phytosociology of north-western Dinaric heaths of the association Rhododendro hirsuti-Juniperetum alpinae Horvat ex Horvat et al. 1974 nom. corr. prop. as well as the syndynamics and synsystematics of heaths in the Dinaric Alps are discussed. While the structure (physiognomy) of these stands is very homogenous and dominated by few species, the flora is heterogeneous, since ecotonal areas, where heaths are most frequently developed, represent a contact zone of elements of different syntaxa. Due to an abrupt reduction in pasture activities strong encroachments of shrubs and trees have become common, which additionally contribute to the floristic heterogeneity of the heaths. Although the identification and circumscription together with synecology and synchorology of heaths in general are more or less easily understood and straightforward, their floristic affinities, in relation to structure homogeneity and syndynamics, are complicated, which led to the proposal of several synsystematic schemes depending on interpretation of the relationship between flora and structure of stands. Dinaric heaths are classified into three classes, Erico-Pinetea, Vaccinio-Piceetea and Festuco-Brometea and a classification scheme is proposed together with nomenclatorial revision of the analyzed heaths with dwarf ericaceous shrubs and Alpine juniper (Juniperus alpina) in the Dinaric Alps.
\end{abstract}

Key words: Dinaric Alps, Ericaceae, Juniperus alpina, phytosociology, Rhododendron hirsutum, synsystematics

\section{Introduction}

An accurate and updated vegetation map is an essential tool for successful conservation planning, monitoring and managing biological diversity and other natural resources both within and outside the existing protected areas. In order to delimit areas with various vegetation types accurately, while assigning them to objective categories that can be easily

* Corresponding author, e-mail address: bostjan.surina@prirodoslovni.com

Copyright ${ }^{\circledR} 2013$ by Acta Botanica Croatica, the Faculty of Science, University of Zagreb. All rights reserved. 
recognized in the field and that reliably reflect fundamental biological differences (primarily the floristic composition and physiognomy), we started with detailed vegetation mapping in the Obruč area (Liburnian karst, Dinaric Alps) in north-western Adriatic (Fig. 1), one of the most important plant areas in Croatia (see RANDIĆ 2009). Vegetation studies in the Obruč mountain range were initiated by Croatian botanist Ivo Horvat and resulted in a worked-out vegetation typology (e.g. HoRvAT 1930, 1931, 1938) and a vegetation map (in collaboration mostly with Z. Pelcer, Z. Matan and S. Bertović) of the broader area (HoRVAT 1962).

Based on a vegetation map of Horvat and co-workers (HORVAT 1962), the study area represents a mosaic of forest and non-forest vegetation types where (subalpine) beech forests of the association Polysticho lonchitis-Fagetum (=Fagetum croaticum australe subalpinum) generally prevail. Southern slopes are covered by thermophilic stands of the association Seslerio autumnalis-Fagetum (=Fagetum croaticum australe seslerietosum) and fir-beech stands of the association Omphalodo-Fagetum var. geogr. Calamintha grandiflora (=Fagetum croaticum australe abietetosum) seslerietosum autumnalis. Stony and steep slopes, intercepted with boulders, gravels and cracks, are covered with more or less pure fir stands of the association Calamagrostido variae-Abietetum (piceetosum). Recently, though not included in the vegetation map, beech stands from the summit were segregated into a new beech association Calamagrostido arundinaceae-Fagetum (CEROVEČKI 2009). Among non-forest vegetation types, botanists mapped three syntaxa: (a) mountain pine scrubs with Pinus mugo of the association Hyperico grisebachii-Pinetum mugo var. geogr. Arabis scopoliana (=Pinetum mughi croaticum [p.p.]), (b) dry and stony grasslands of the subassociation Carici humilis-Centaureetum rupestris seslerietosum tenuifoliae (=Cariceto-Centaureetum rupestris [p.p.]), and (c) heaths with Rhododendron hirsutum and Juniperus alpina (=Juniperus communis L. subsp. sibirica (Suter) Čelak., J. nana Willd.; Rhodereto-Juniperetum).

\section{Syntaxonomy of »heaths«}

Besides the many typological and nomenclatorial issues among most of the above-mentioned syntaxa (compare WeBER et al. 2000), we find the synsystematics and syndynamics of stands dominated by hairy Alpenrose (Rhododendron hirsutum), Alpine juniper (Juniperus alpina) and large-leaved willow (Salix appendiculata), although of homogenous structure, the most difficult problem to solve. These heaths are usually established in a phytoclimatic belt which is characterized by the timberline and/or isolated tree lines, within more or less large ecotone areas, once used for pastures but, due to overall changes in the socioeconomic situation, now almost completely abandoned (PoLDINI et al. 2004). As a result, these areas are nowadays exposed to rapid dynamic phenomena and abrupt changes in vegetation cover. The climatogenic timberline in the Liburnian karst exceeds the highest peaks due to the overall relatively low altitude (the highest peak, Mt Snežnik, reaches 1796 $m$ a.s.l.). However, under anthropogenic influence, and rarely due to extreme environmental site conditions (e.g. steep slopes, sites exposed to strong Bora etc.), the man-made limit of the timberline and/or isolated tree, due to pasture and logging economy, might lie considerably lower than the climatogenic one (e.g. WrABER 1997).

HORVAT (1962) found structurally homogenous and ecologically well defined heaths with Rhododendron hirsutum and Juniperus alpina developed on exposed ridges of lower altitude (between 1200-1400 m a.s.1.). He placed them into the association Rhododendro- 
-Juniperetum nanae and afterwards supported this with an incomplete synoptic table (HORVAT et al. 1974, Tab. 135, col. 1, 16 relevés). These stands, according to vegetation map, are more or less frequent in the Obruč (the main ridge, Pakleno, Mts Suhi vrh, Fratar and Gornik), Snježnik (Bjela Škalja and Ceclje area, Medvejci, Planina and Guslice) and Risnjak area above $1200 \mathrm{~m}$ a.s.l. Similar stands were observed on sites with similar ecological conditions in the Slovenian part of the Liburnian karst as well, on the Snežnik plateau, between 1200-1600 m a.s.l., in the area of Gornji Dužovec, Zatrep, Grdobe, Planinc, Ilovca, Stanišče, Ždrocle etc. and mapped as Rhododendro hirsuti-Salicetum appendiculatae.

Structurally similar, but strikingly different in floristic composition are thermophilic stands with Juniperus alpina and Sesleria robusta from the Biokovo mountain range (Croatia, central Dalmatia) described by Domac as Seslerio robustae-Juniperetum sibiricae (DomAC 1962, VRDOLJAK 1983). Besides hosting a considerable number of Dinaric tussock (Seslerion tenuifoliae) and sub-Mediterranean grassland taxa (Satureion subspicatae), these stands are characterized by the absence of Rhododendron hirsutum and other de-alpine taxa. Within these stands, a subassociation - pinetosum dalmaticae - was recognized on the basis of the presence and/or dominance of Pinus nigra ssp. dalmatica, the only real differential taxon for the floristically and structurally based subassociation. On Jahorina mountain range (central part of Bosnia and Herzegovina) BJELČIĆ (1966) placed stands dominated by Juniperus alpina into the association Junipero sibiricae-Semperviretum schlechanii, while similar stands on Mt Bjelasica in Montenegro, developed on somewhat more acidic soils, were studied by LAKUŠIĆ (1966) who at that time recognized two new associations: Roso pendulinae-Juniperetum nanae and Hyperici-Vaccinietum montenegrini. On Vranica mountain range (central Bosnia and Herzegovina), a geologically diverse area characterized by a mixture of calcareous and siliceous bedrocks, LAKUŠŕc et al. (1979) studied more acidophytic (Hyperici-Vaccinetum bosniacum, Vaccinio-Callunetum subalpinum) and relatively basiphytic stands (Aquilegio-Rhododendretum hirsuti, Arctostaphylletum uvae-ursi) dominated by dwarf ericaceous species.

While the structure (physiognomy) of these stands is very homogenous and dominated by few species such as Rhododendron hirsutum, Juniperus alpina, Salix appendiculata, Erica carnea, Calamagrostis varia and Rosa pendulina, the flora is heterogeneous since this ecotonal area represents a contact zone of elements of different syntaxa. Additionally, due to a conspicuous reduction in pasture activities, strong encroachments of phanerophytes have become common contributing to a mixture of floristic composition of stands. Although the identification and circumscription together with synecology and synchorology of the heaths in general are more or less simple and straightforward, their floristic affinities, in relation to structure homogeneity and syndynamics, are complicated, which led to the proposal of several syntaxonomic schemes depending on the interpretation of the relationship of the two aspects, focusing either on the flora (e.g. WALLNÖFER 1993a, 1993b), the structure (e.g. HoRvat 1962, HoRvat et al. 1974, THeURILlat et al. 1995, STANISCI 1997), or both (PoldiNI et al. 2004). TheuRILlat et al. (1995) placed all mountain pine scrubs, regardless of the substrate, into a new class Roso pendulinae-Pinetea mugi, while they classified all the orotemperate heaths into the class Loiseleurio-Vaccinietea. On the other hand, WALLNÖFER (1993a, 1993b) differentiated acidophilic (Vaccinio-Piceetea) and basiphilic mountain pine scrubs (Erico-Pinetea), while acidophilic heaths were included into the class Loiseleurio-Vaccinietea and basiphilic into the class Seslerietea albicantis. In the Apennines (STANISCI 
1997), mountain pine scrubs and formations with Juniperus alpina lack many boreo-alpine elements and were therefore referred to the class Pino-Juniperetea, a class consisting of orophilous communities dominated by conifers in the circum-Mediterranean area. In the Dinaric Alps (e.g. BlEČIĆ 1957, 1958, LAKUŠIĆ 1966, BJELČIĆ 1966, LAKUŠIĆ et al. 1979, ZuPANČIČ et al. 2004, 2006, VuKELIĆ et al. 2008), mountain pine scrubs and dwarf ericaceous scrubs, strongly influenced by the researches of BRAUN-BLANQUET (1931) and HORVAT (e.g. 1938, 1962, 1974), were classified in different subordinate syntaxa into the class Vaccinio-Piceetea without an exception.

In our study we aim to: (1) elucidate the phytosociological characteristics and site conditions of structurally similar but floristically different stands of north-west Dinaric heaths with hairy Alpenrose Rhododendron hirsutum and Alpine juniper Juniperus alpina, (2) identify the potential vegetation cover and syndynamic relationships between the north-west Dinaric heaths and surrounding forest and non-forest vegetation types and (3) to propose a sensible syntaxonomic scheme for the heaths of the Dinaric Alps.

\section{Methods}

In years 2005 and 2011, we recorded 22 relevés dominated by Rhododendron hirsutum and Juniperus alpina in the Liburnian karst (Fig. 1) applying the standard Central-European method (Braun-Blanquet 1928, WesthofF and VAN DER MAAREL 1973, DierschKe 1994). The plot size used for sampling averaged $30 \mathrm{~m}^{2}$ and further details on the phytosociological parameters of sites are given in Appendix I. A complete floristic inventory is given in table 2, while taxa occurring in a single relevé are listed in Appendix II. Coverage index (D\%, e.g.

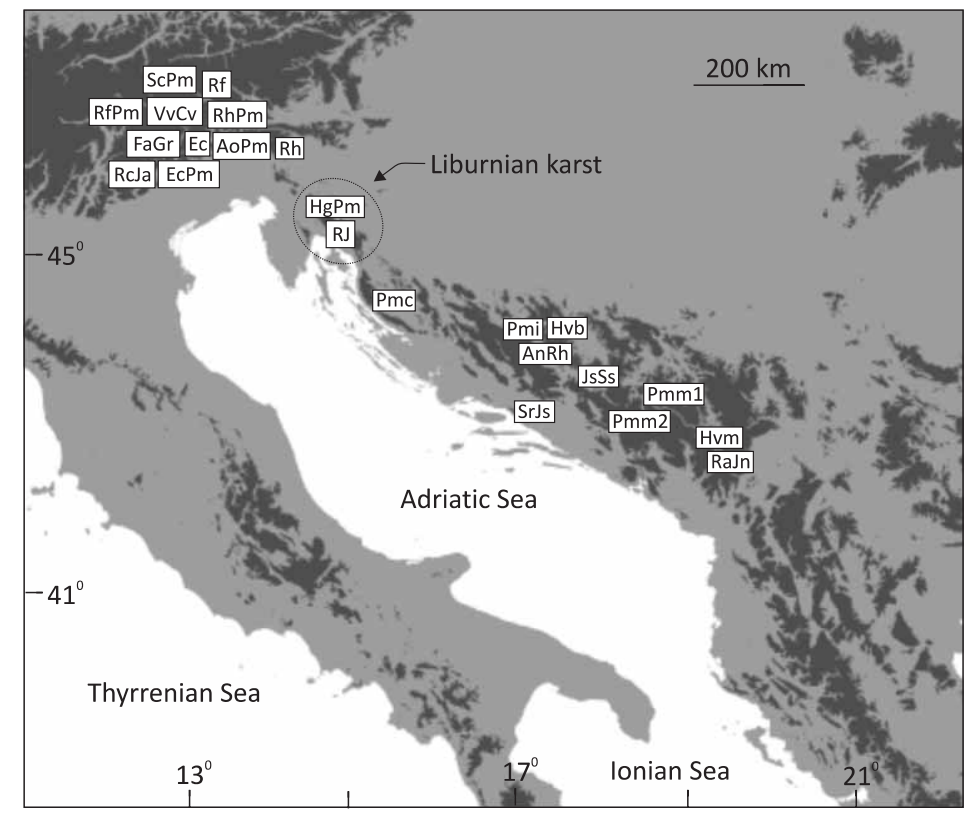

Fig. 1. Map showing the study area (hatched line) and approximate localities of the syntaxa from table 1 with corresponding acronyms. 
Surina 2005) was calculated for each taxon in table 2. The nomenclature and taxonomic source for the names of vascular plants was Mala flora Slovenije (MARTINČIČ et al. 2007). Syntaxonomic groups in tables 2 and 3 were assigned according to Flora Alpina (AESCHIMANN et al. 2004), DAKSKOBler (2006) and Poldini et al. (2004) and the list of syntaxa with full names is given in Appendix III. Prior to numerical analysis, the original cover-abundance values for individual taxa were transformed into an ordinal scale as proposed by van der MAAREL (1979). Groups of vegetation types were ascertained using cluster and ordination analysis with the help of the programme package PAST (HAMMER et al. 2001). The arrangement of relevés in table 2 was done according to the results of cluster analysis (Fig. 2a) and diagnostic groups of species were subsequently tested by means of the SIMPER analysis, an algorithm implemented in programme package PAST. In order to explain the
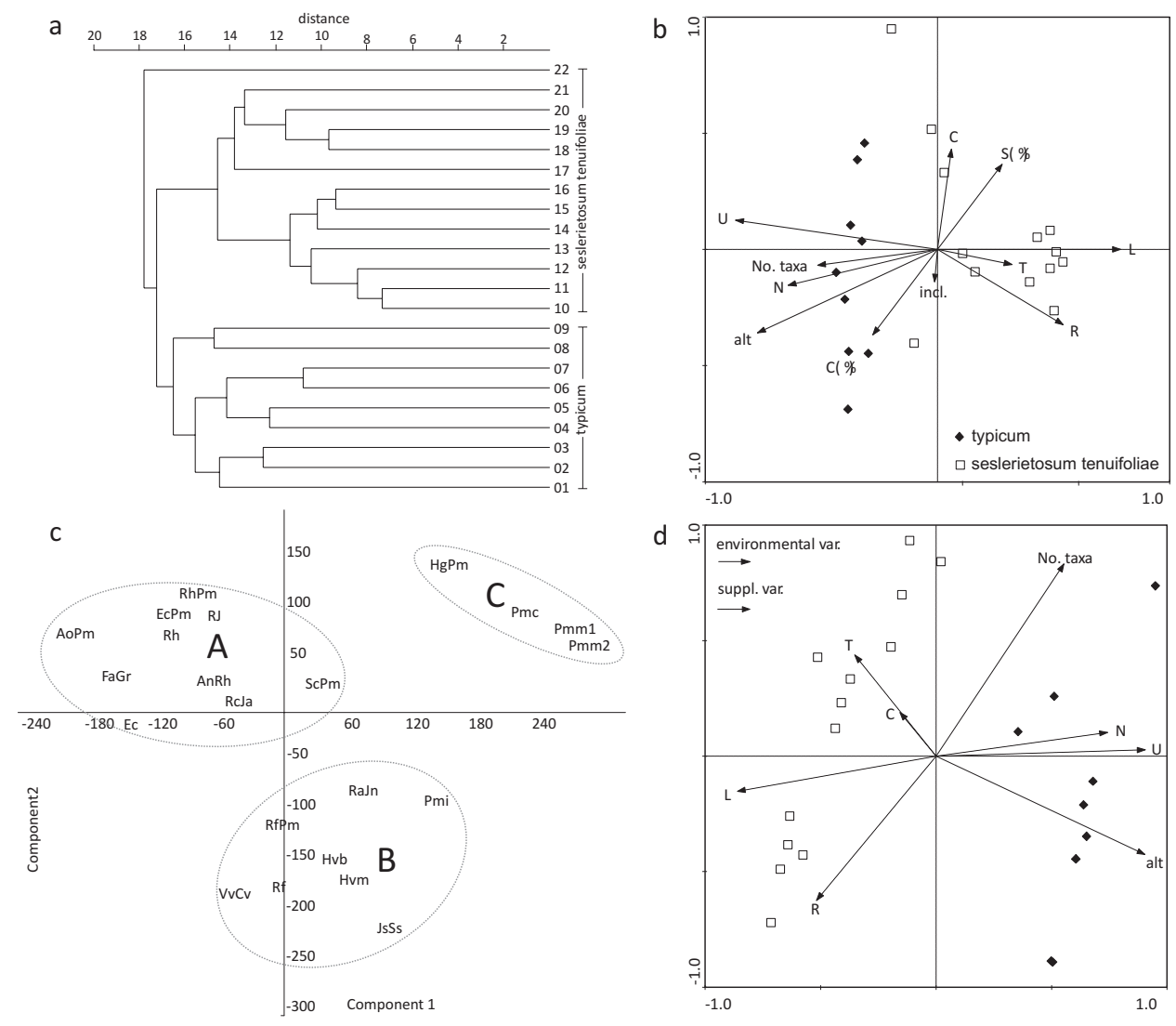

Fig. 2. The results of (a) cluster (UPGMA), (b) PCA (eigenv.: $1-0.883,2-0.687,3-0.6794-$ 0.695 ; cumulative percentage variance of species-environment relation [in \%]: $1-45.1,2-$ 58.5, 3 - 68.7, 4 - 77.6; (c) ordination (Euclid distances, eigenv.: 1 - 19,7\%, 2 - 12\%, 3 10,5\%; acronyms correspond to those in Fig. 1 and Tab. 1) and (d) DCA (eigenv.: 1 - 0.885, 2 - 0.703, $3-0.759,4-0.585$; cumulative percentage variance of species-environment relation [in \%]: $1-42.8,2-50.0,3-76.9,4-82.2$ ) analysis of stands with dominating Rhododendron hirsutum and Juniperus sibirica in the Liburnian karst (north-west Dinaric Alps) and structurally similar stands from the South-eastern Calcareous and Dinaric Alps. 


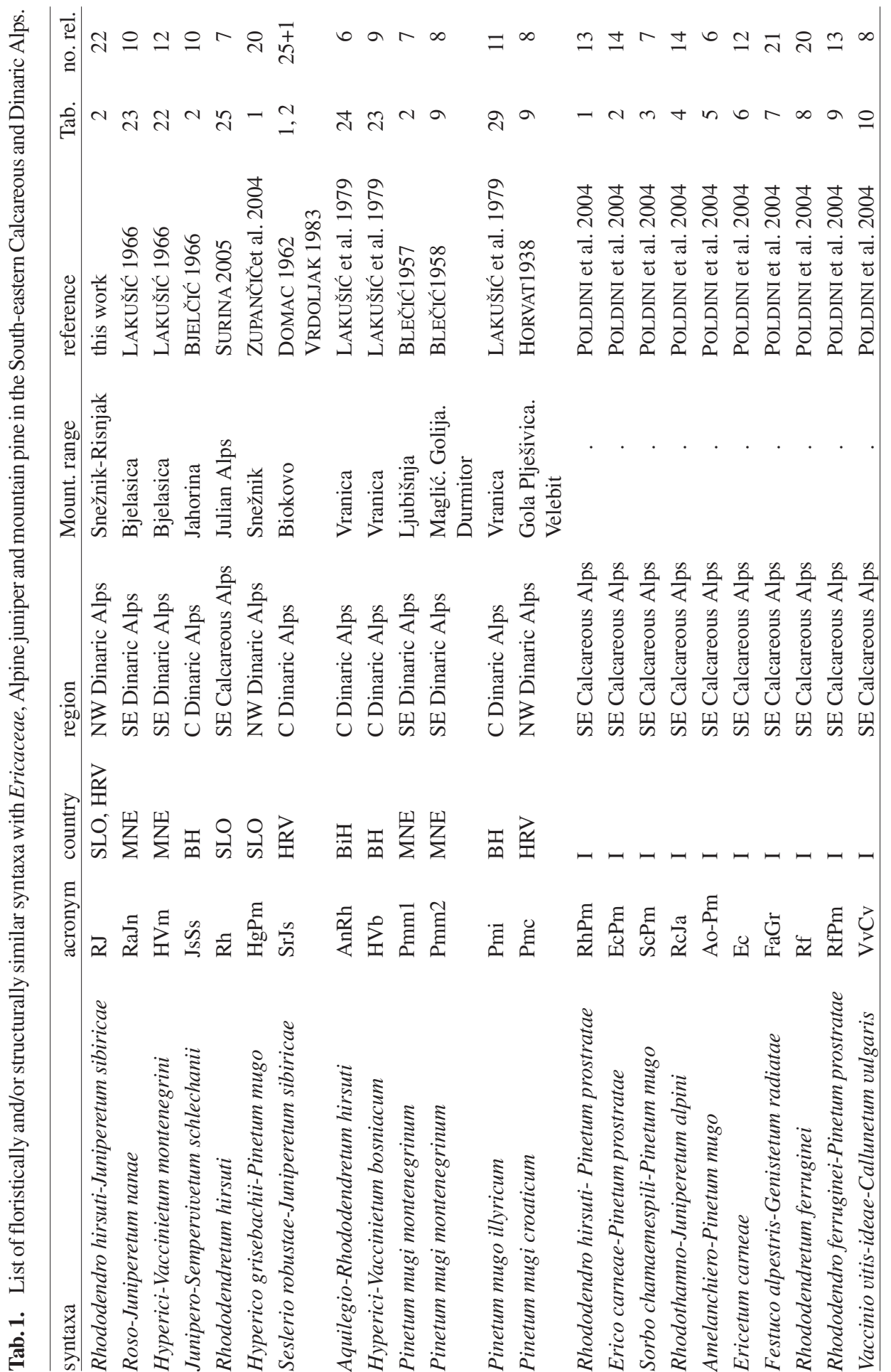


variation by specific environmental and structural (phytosociological) variables, unconstrained (PCA, DCA) and constrained (RDA) ordination analyses were performed, using the CANOCO computer programme (BRAAK TER and ŠMILAUER 2002). In order to determine the lengths of gradients, DCA analyses, detrended by segments, were initially performed and the models (linear, unimodal) used accordingly. The statistical significance of the site parameters $(\mathrm{p}<0.05)$ was tested using the Monte Carlo test, with 499 permutations. Only the significant parameters were then analyzed together, in order to produce a general view of the environmental impact on floristic composition and structure of stands. For estimating the environmental affinities of the relevés, we used Pignatti's indicator values for vascular plants (PIGNATTI 2005). The environmental value in a relevé $\left(\mathrm{EV}_{\mathrm{w}}\right)$ was estimated as the weighted average of the indicator values of all present species, their abundances being used as weights (LEPŠ and ŠMILAUER 2003).

Heaths from the Liburnian karst were compared with mountain pine scrubs and structurally similar stands with dwarf ericaceous scrubs and/or Alpine juniper from other parts of the Dinaric Alps and South-eastern Calcareous Alps between Italy and Montenegro (Tab. 1, Fig. 1).

\section{Results}

Floristic composition and structure of the Liburnian (the north-western Dinaric) heaths

We recorded 98 taxa of phanerogams in 22 relevés with a median number of 27 per relevé ( $\min =17, \max =37$; Tab. 2 ). Coefficient of variation of the number of taxa per relevé is $19.63 \%$. Rhododendron hirsutum ${ }^{+-4}\left(\mathrm{D}_{\%}=7.7\right)$, Juniperus alpina ${ }^{+-4}(6.7)$, Salix appendiculata $^{1-3}(6.4)$ and Calamagrostis varia ${ }^{1-2}(5.4)$ occurred in all relevés with high or the highest coverage of all recorded taxa. Almost one quarter of the all registered taxa occurred in more than $50 \%$ of relevés, with the highest presence and coverage shown by Cyclamen purpurascens $^{+-2}(3.5)$, Rosa pendulina $^{+-2}(3.9)$, Allium ericetorum ${ }^{+-2}(3.7)$, Erica carnea ${ }^{1-4}(4.5)$, Campanula cochleariifolia $^{+-2}$ (2.6), Thesium linophyllum ${ }^{+-2}$ (2.2), Picea abies ${ }^{+-1}$ (1.7), Clematis alpina $^{+-2}(2.2)$ and Aster bellidiastrum ${ }^{+-2}$ (2.5). The structure of stands is defined by their edificators, Rhododendron hirsutum, Juniperus alpina and Salix appendiculata, forming more or less dense scrubby vegetation type not exceeding $1 \mathrm{~m}$ in height. As a rule, these stands are developed on very shallow organogenic soil - lithosol or even over a bare, compact to fragmented limestone bedrock on gravelly slopes of mountain ridges above $1200 \mathrm{~m}$ a.s.l., with long-lasting snow cover where northerly exposed sites prevail. Here, the studied stands are in close contact with subalpine beech (Polysticho-Fagetum), fir-spruce (Calamagrostido-Abietetum) and Dinaric fir-beech forest stands (Omphalodo-Fagetum) as well as with scrubby stands of mountain pine (Hyperico-Pinetum mugo), forming transitions toward forest vegetation types. In frost hollows, an ecologically extreme habitat with specific microsite conditions (e.g. MARTINČIČ 1977, SURINA and VREŠ 2004, 2009, MODRIĆ SURINA and SURINA 2010), the studied stands prefer southerly exposed gravelly slopes and close contact with azonal spruce (Lonicero caeruleae-Piceetum, Hacquetio-Piceetum) and extrazonal subalpine beech forest stands with hairy Alpenrose - Polysticho-Fagetum rhododendretosum (SURINA and RAKAJ 2007), but more frequently with non-forest stands with Carex ferruginea, Salix appendiculata stands, Doronico austriaci-Adenostyletum alliariae, and Drepanoclado uncinati-Heliospermetum pusilli, the last representing the most cryophilic stands developed specifically in frost hollows of north-western Dinaric Alps. 


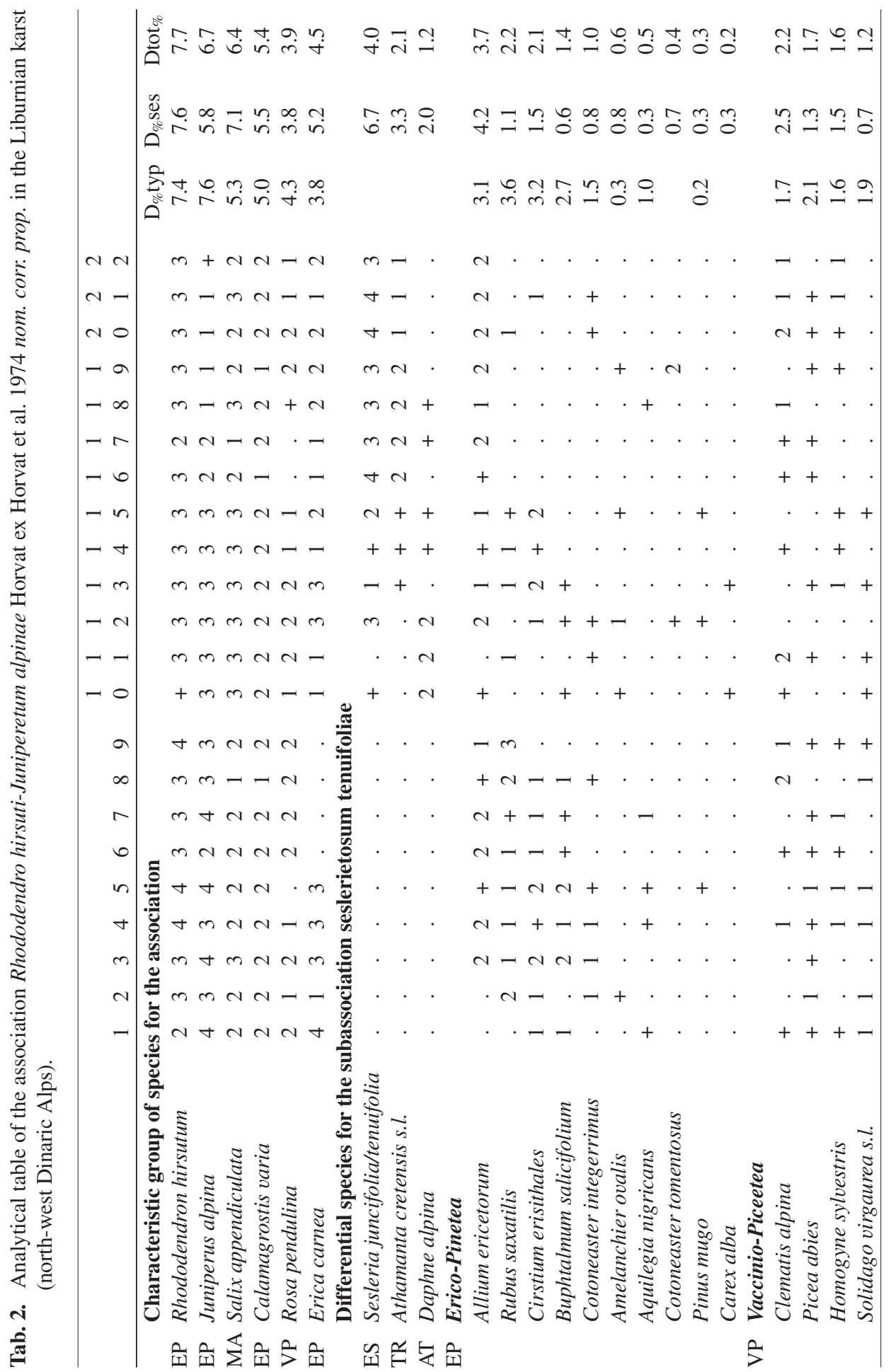




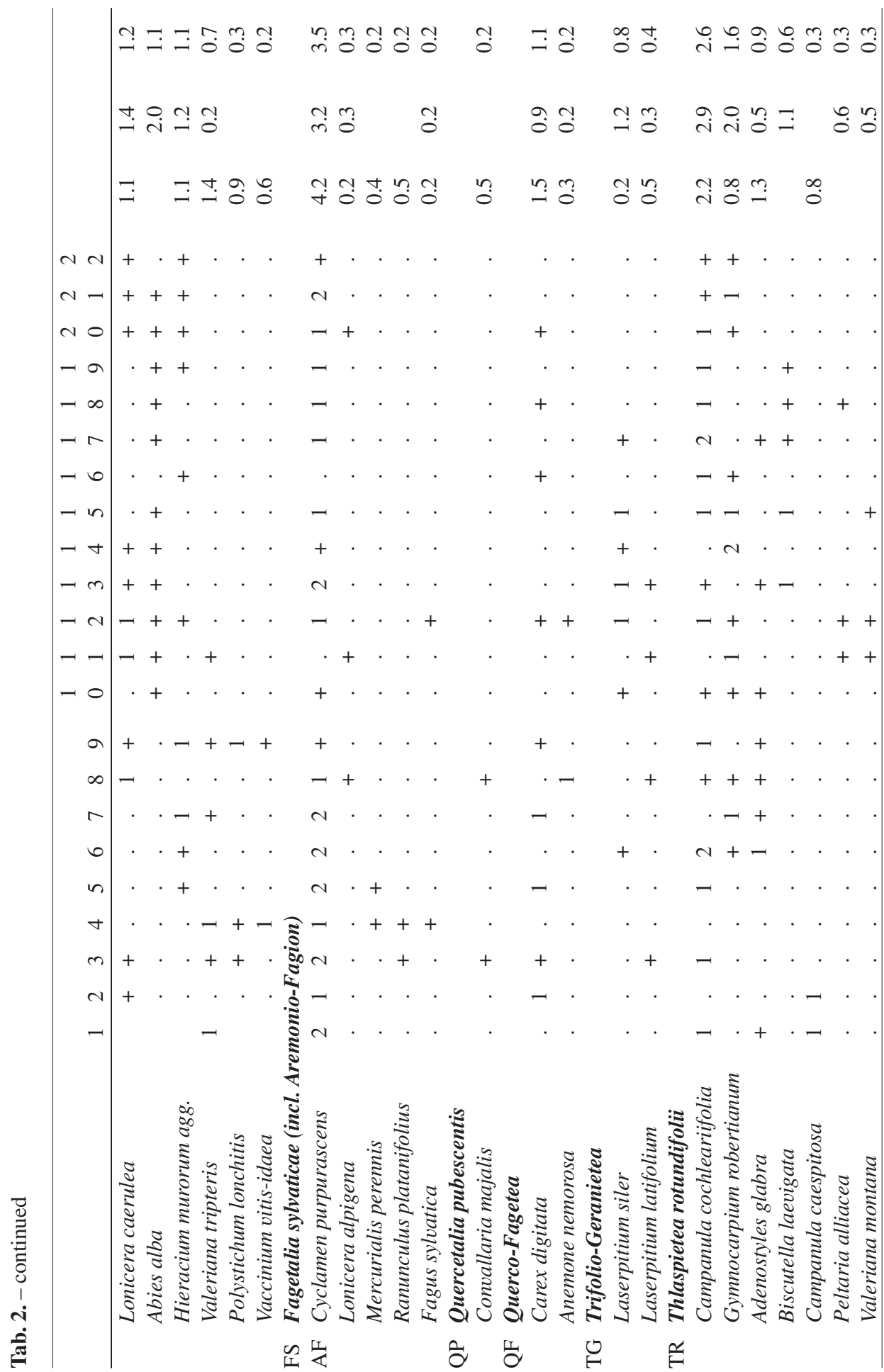




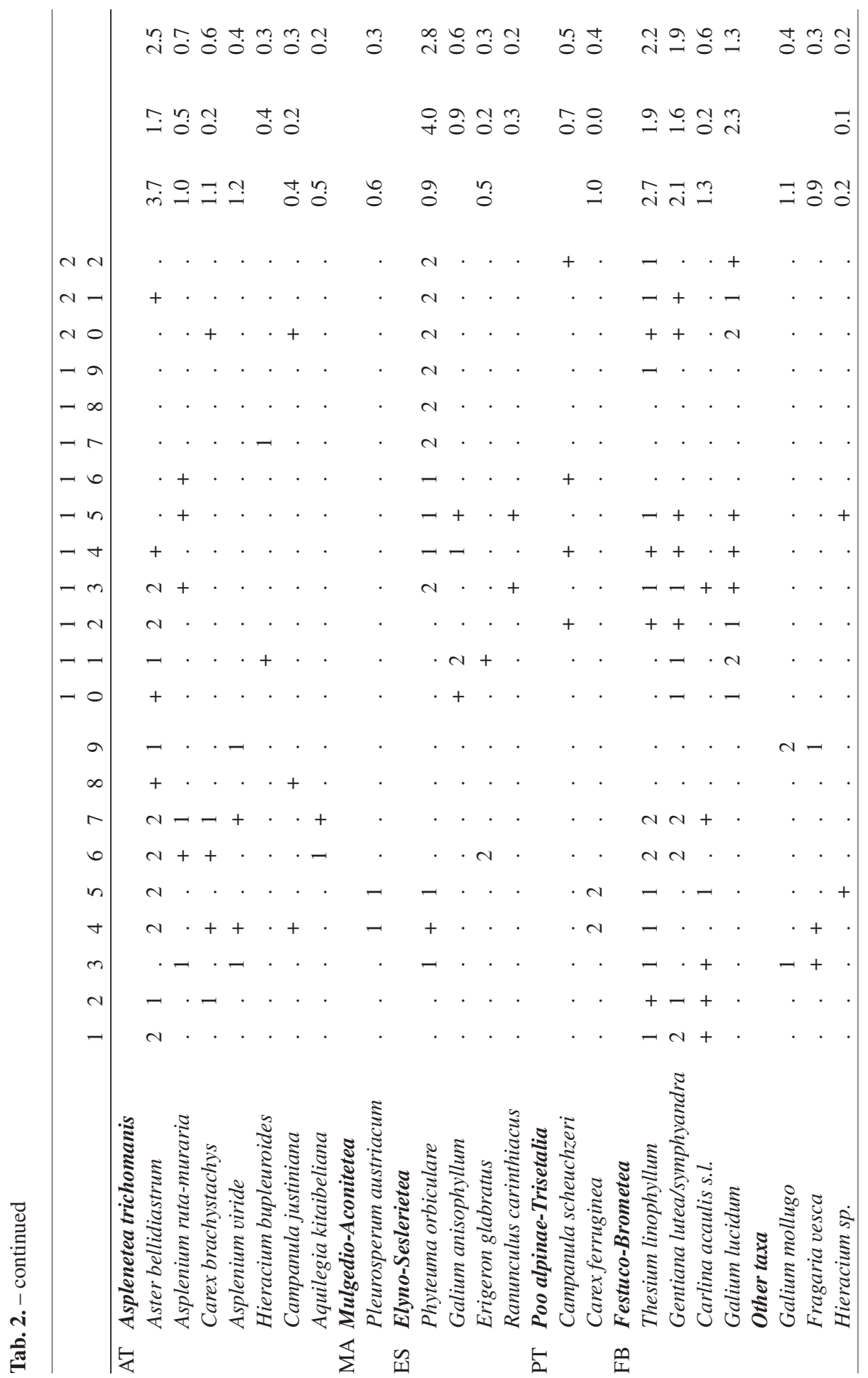


Generally, species of the class Erico-Pinetea completely dominate in stands, being the most frequent and achieving the highest coverage indices $\left(\mathrm{D}_{\%}=44.4\right.$, Tabs. 2,3$)$, followed by spruce forest species (Vaccinio-Piceetea, 15.5) and petrophytic species of screes and rock crevices (Thlaspietea rotundifolii, 9.6 and Asplenietea trichomanis, 6.7, respectively). Dry grassland species of the class Festuco-Brometea (6.2) are represented by six species, the most frequent, occurring in more than $50 \%$ of relevés, being Thesium linophyllum and Gentiana lutea subsp. symphyandra ${ }^{+-2}(1.9)$. There are 11 beech forest species (Fagetalia sylvaticae, 5.2) recorded in the studied stands, but although Cyclamen purpurascens ${ }^{+-2}$ (3.5), occurs in more than $90 \%$ of relevés, the others, a negligible coverage, are much less frequent.

Although structurally very similar, the studied stands form floristically and ecologically two well circumscribed vegetation types (Tabs. 2, 3, Fig. 2 a, b, d). Stands from the first group (»typical« ones) are developed at more elevated, cooler, moister, shadier, sheltered and more nutrient-rich sites. These stands are characterized by higher number and coverage of spruce forest species which is in line with overall lower values for the substrate $\mathrm{pH}$ reaction and cooler sites. On the other hand, stands from the second group (-seslerietosum tenuifoliae) are developed on warmer and lighter sites at lower altitudes but, also thrive on northerly exposed slopes of the ridge, more exposed to strong winds. These stands host a considerably higher number and greater coverage of species preferring open habitats (screes - Thlaspietea rotundifolii, subalpine Dinaric tussock grasslands - Elyno-Seslerietea). Among the phytosociological parameters, the altitude $(\mathrm{P}=0.002)$ and the number of species per relevé $(\mathrm{P}=0.006)$ turned out to be statistically significant factors in floristic differentiation of stands. The first group of stands is clearly separated from the second one along the altitudinal gradient. Results of the SIMPER analysis showed the overall average dissimilarity between the two groups to be 51.84 with the taxa that contributed most to the dissimilar-

Tab. 3. Coverage indices $\left(\mathrm{D}_{\%}\right)$ according to syntaxonomic groups within the association Rhododendro hirsuti-Juniperetum alpinae Horvat ex Horvat et al. 1974 nom. nov. prop. in the Liburnian karst (north-west Dinaric Alps).

\begin{tabular}{lccc}
\hline syntaxa & typical stands & seslerietosum & association \\
\hline Erico-Pinetea & 38.2 & 47.8 & 44.4 \\
Vaccinio-Piceetea & 17.2 & 14.4 & 15.5 \\
Thlaspietea rotundifolii & 6.0 & 11.7 & 9.6 \\
Elyno-Seslerietea & 1.5 & 12.2 & 1.6 \\
Mulgedio-Aconitetea & 7.1 & 7.2 & 7.1 \\
Asplenietea trichomanis & 7.2 & 6.6 & 6.7 \\
Festuco-Brometea & 6.1 & 6.1 & 6.2 \\
Fagetalia sylvaticae & 6.7 & 4.2 & 5.2 \\
Trifolio-Geranietea & 0.7 & 1.9 & 1.4 \\
Querco-Fagetea & 2.1 & 1.1 & 1.4 \\
Poo alpinae-Trisetalia & 1.0 & 0.7 & 0.9 \\
Other taxa & 2.1 & 0.2 & 0.8 \\
Quercetalia pubescentis & 0.7 &. & 0.3 \\
Molinio-Arrhenatheretea & 0.3 &. & 0.1 \\
\hline
\end{tabular}


ity being Sesleria juncifolia subsp. tenuifolia (3.1), Erica carnea (1.8), Phyteuma orbiculare (1.7), Aster bellidiastrum (1.5), Athamanta cretensis (1.5), Rubus saxatilis (1.4) etc. Even the coefficient of variation of the number of taxa per relevé showed differences, being in the first group (»typical« stands) significantly lower (16.5\%) than in the second one $(21.5 \%)$ which might indicate more homogenous floristic composition of stands within the first group. Based on the results of the SIMPER analysis and ecological preferences of taxa in general, as a differential group of species for the second group of stands we chose Sesleria juncifolia subsp. tenuifolia ${ }^{+-4}$ (6.7), Athamanta cretensis $^{+-2}$ (3.3) and Daphne alpina ${ }^{+-2}$ (2), exclusively differentiating the two groups. A taxonomic note: the taxonomic status of specimens of Athamanta cretensis (var. mutellinoides?) from the Liburnian karst is uncertain; specimens at lower altitudes (1000-1300 m) differ morphologically and physiognomically from typical ones found on higher altitude summits (e.g. Mt. Snežnik, 1796 m, or Mt. Snježnik, $1524 \mathrm{~m}$ ), and are similar to specimens of A. haynaldii Borb. et Uechtr.

\section{Syntaxonomic position and notes on nomenclature of Dinaric heaths}

Comparison of the floristic inventory in table 2 and that in the reduced synoptic table 135 in HORVAT et al. (1974) clearly showed that the studied stands belong to the association Rhododendro hirsuti-Juniperetum Horvat 1962. However, in his original diagnosis (HORVAT 1962), the author failed to designate the type relevé (Art. 2b, 7 and 17 of the Phytosociological code), nor did he provide an analytical and/or synoptic table, although subsequently (HoRvat et al. 1974) he did publish a synoptic table (Tab. 135, col. 1), which, according to Art. 7 (WeBER et al. 2000), is the first valid publication of a name (Definition III) Rhododendro hirsuti-Juniperetum alpinae Horvat ex Horvat et al. 1974 nom. corr. prop. (=Rhododendro hirsuti-Juniperetum Horvat 1962 nom. nud.). As a neotype (Definition VIII) we chose a relevé no. 4 in table 2, neotypus hoc loco. Within the studied stands, we recognized a new subassociation Rhododendro hirsuti-Juniperetum alpinae seslerietosum tenuifoliae subass. nova hoc loco, and as a differential group of species for the subassociation we chose Sesleria juncifolia subsp. tenuifolia, Athamanta cretensis and Daphne alpina. Nomenclature type for the new subassociation is relevé no. 17 in table 2, holotypus hoc loco.

Results of the ordination analysis (Fig. 2c) and cluster analyses using various similarity measures (not shown) suggest great floristic similarity between stands of the association Rhododendro hirsuti-Juniperetum from the Liburnian karst (RJ) and stands from the South-eastern Calcareous Alps, belonging to the associations Rhododendro hirsuti-Pinetum prostratae (RhPm), Erico carneae-Pinetum prostratae (EcPm) and Rhododendretum hirsuti (Rh; group A). In all three associations, species from the class Erico-Pinetea prevail both in number and coverage over the species of the other syntaxa and we classified stands from the Liburnian karst into class Erico-Pinetea, order Erico-Pinetalia and alliance Ericion carneae (see below). Stands of the association Aquilegio-Rhododendretum hirsuti (AnRh) were nested in the same group of relevés (Fig. 2c, group A) indicating close floristic and ecological similarity. Hence, we classified them into the alliance Ericion carneae. Although the syntaxon Aquilegio-Rhododendretum hirsuti is supported with the analytical table (Tab. 24 in LAKUŠIĆ et al. 1979), the type relevé has not been designated and is, according to Definition IV of the Code (compare also Articles 5, 15-18), treated as an unpublished name. As a lectotype of the association Aquilegio nigricantis-Rhododendretum hirsuti Lakušić et al. ex 
Surina ass. nova (=Aquilegio -Rhododendretum hirsuti Lakušić et al. 1979 nom. inv.), we chose relevé no. 2 in tab. 24 in LAKUšıć et al. 1979, lectotypus hoc loco.

Dinaric scrubs of Mountain pine (HgPm, Pmc, Pmm 1, 2) formed a group C (Fig. 2c), while more acidophilic syntaxa, either heaths (VvCv, Rf, HVb, HVm, RaJn, JsSs) or mountain pine scrubs (RfPm, Pmi), formed another homogenous group (group B, Fig. 2c). We classified the later, being distinctly acidophilic, into the class Vaccinio-Piceetea, order Vaccinio-Piceetalia and alliance Rhododendro-Vaccinion. The associations Hyperico-Vaccinietum bosniacum, Hyperici-Vaccinietum montenegrinum and Vaccinio-Callunetum subalpinum are invalidly published, violating the principles of phytosociological nomenclature in several articles (e.g. Art. 5, 10, 15-18, 46). Hence, validly published names with selected lectotypes are proposed: Hyperico maculati-Vaccinietum myrtilli Lakušić et al. ex Surina ass. nova (=Hyperico-Vaccinietum bosniacum Lakušić et al. 1979 nom. inv.), lectotypus hoc loco: relevé no. 2 in table 23 in LAKUŠIĆ et al. (1979); Hyperico grisebachii-Vaccinietum myrtilli Lakušić ex Surina ass. nova (=Hyperici-Vaccinietum montenegrinum Lakušić 1966 nom. inv.), lectotypus hoc loco: relevé no. 6 in table 22 in LAKUŠıć (1966); Vaccinio myrtilli-Callunetum vulgaris Lakušić et al ex Surina ass. nova (=Vaccinio-Callunetum subalpinum Lakušić et al. 1979 nom. inv.), lectotypus hoc loco: relevé no. 10 in table 23 in LAKUŠIĆ et al. (1979). According to the results of the analyses, stands of the associations Roso pendulinae-Juniperetum alpinae Lakušić 1966 nom. corr. prop. (Art. 41; =Roso pendulinae-Juniperetum nanae Lakušić 1966) and Sempervivo schlechanii-Juniperetum alpinae Bjelčić 1966 nom. invers. et corr. prop. (Art. 42; =Junipero-Semperviretum schlechanii Bjelčić 1966), gathered in group C together with stands of the associations Hyperico maculati-Vaccinietum myrtilli, Hyperico grisebachii-Vaccinietum myrtilli and Vaccinio myrtilli-Callunetum vulgaris, showed considerable floristic similarities and are thus classified accordingly. For the two mentioned syntaxa, lectotypes were here designated: Roso pendulinae-Juniperetum alpinae Lakušić 1966 nom. corr. prop., lectotypus hoc loco: relevé no. 4 in table 22 in LAKUŠIć (1966); Sempervivo schlechanii-Juniperetum alpine Bjelčić 1966 nom. invers. et corr. prop., lectotypus hoc loco: relevé no. 6 in table 2 in BJELČÍć (1966).

In all the numerical analyses we performed, relevés of the association Seslerio robustae-Juniperetum alpinae Domac 1962 nom. corr. prop. formed a completely separated and floristically clearly distinct group of stands, being the most thermophilic and composed of a significant number of species of the class Festuco-Brometea. Therefore, we omitted this syntaxon from the subsequent analyses and classified it within the class Festuco-Brometea, order Scorzonero-Chrysopogonetalia and alliance Satureion subspicatae.

Erico-Pinetea Horvat 1959

Erico-Pinetalia Horvat 1959

Ericion carneae Rübel ex Grabherr et al. 1993

Aquilegio nigricantis-Rhododendretum hirsuti Lakušić et al. ex Surina ass. nova hoc loco (=Aquilegio-Rhododendretum hirsuti Lakušić et al. 1979 nom. inv.)

Rhododendro hirsuti-Juniperetum alpinae Horvat ex Horvat et al. 1974 nom. corr. prop.

(=Rhododendro-Juniperetum Horvat 1962 nom. nud.)

-seslerietosum tenuifoliae Surina subass. nova hoc loco

Vaccinio-Piceetea Br.-Bl. in Br.-Bl. et al. 1939 emend. Zupančič (1976) 2000

Piceetalia excelsae Pawlowski in Pawlowski et al. 1928

Rhododendro-Vaccinion (Br.-Bl. in Br.-Bl. et Jenny 1926) Br.-B1. 1948

Roso pendulinae-Juniperetum alpinae Lakušić 1966 nom. corr. prop. 


\author{
(=Roso pendulinae-Juniperetum nanae Lakušić 1966) \\ Sempervivo schlechanii-Juniperetum alpinae Bjelčić 1966 nom. invers. et corr. prop. \\ (=Junipero-Sempervivetum schlechanii Bjelčić 1966) \\ Hyperico maculati-Vaccinietum myrtilli Lakušić et al. ex Surina ass. nova hoc loco \\ (=Hyperici-Vaccinietum bosniacum Lakušić et al. 1979 nom. inv.) \\ Hyperici grisebachii-Vaccinietum myrtilli Lakušić ex Surina ass. nova hoc loco \\ (=Hyperici-Vaccinietum montenegrinum Lakušić 1966 nom. inv.) \\ Vaccinio myrtilli-Callunetum vulgaris Lakušić et al. ex Surina ass. nova hoc loco \\ (Vaccinio-Callunetum subalpinum Lakušić et al. 1979 nom. inv.) \\ Festuco-Brometea Br.-B1. et Tx. 1943 \\ Scorzonero-Chrysopogonetalia Horvatić et Horvat (1956) 1958 \\ Satureion subspicatae Horvat 1961 \\ Seslerio robustae-Juniperetum alpinae Domac 1962 nom. corr. prop.
}

\title{
Discussion
}

According to our observations, heaths of the association Rhododendro hirsuti-Juniperetum alpinae persist in sites with extremely low winter temperatures, but with long duration of snow cover, where stands covered with snow are sheltered from low temperature extremes, winter desiccation, ice blast and solar radiation. The same pattern with structurally similar stands on Mt. Jahorina was thoroughly discussed by BJELČIĆ (1966). It seems that in our case extreme winter temperatures on sites with ericaceous heaths are buffered with deep and persistent snowpacks originating either from blasts of snow along the mountain ridges or specific microclimate of frost dolines (temperature inversion!). The specific origin of snowpacks, as well as specifics in relief, are well reflected in floristic composition of stands and distinction of the two subassociations: (a) -typicum, with cryophilic stands developed in moister and cooler sites at the margins or on slopes of frost dolines, and (b)-seslerietosum tenuifoliae, with relatively thermophilic stands developed on warmer, lighter and wind exposed sites on mountain ridges.

Although within a rather restricted area of the Liburnian karst, structurally identical but, in terms of their origin, floristic composition and specifics in site ecology, nevertheless different groups of stands were identified. Due to site ecology and pronounced human impact (deforestation due to intensive logging and subsequent soil erosion and pasture activities), these stands, which are in contact with various forest and non-forest stands, but in general developed within the stands of zonal association Polysticho lonchitis-Fagetum, host a plethora of species of different vegetation types (classes, see POLDINI et al. 2004), rendering synsystematic and syndynamic analyses particularly troublesome. Although there were earlier attempts to explain the origin and syndynamics of studied heaths (e.g. HoRvAT 1962, BJELČIĆ 1966), none of the proposed schemes actually suffice and the question of heath syndynamics, at least in the Dinaric Alps, remains an open question. This is followed with uncertainties in heath synsystematics where several authors proposed various synsystematic schemes based either on floristic principle, structure of stands of both. In our proposal we followed the compromise made by POLDINI et al. (2004), placing heaths on the basis of floristic principle into two classes: Erico-Pinetea and Vaccinio-Piceetea, and only latter, while classifying the associations into the syntaxa ranked bellow the class, took into the consideration their structure. Hence, the Dinaric associations Rhododendro hirsuti-Juniperetum alpinae and Aquilegio nigricantis-Rhododendretum hirsuti (their stands being de- 
veloped on calcareous soils) were placed within the class Erico-Pinetea, while associations Roso pendulinae-Juniperetum alpinae, Sempervivo schlechanii-Juniperetum alpinae (their stands being developed on non-calcareous soils or on sites with close contact to spruce forests, respectively), Hyperico maculati-Vaccinietum myrtilli and Vaccinio myrtilli-Callunetum vulgaris (their stands being developed on non-calcareous soils) within the class Vaccinio-Piceetea. This scheme is well supported by the results of the numerical analyses (Fig. 2c). The association Arctostaphylletum uvae-ursi silicicolum Lakušić et al. 1979 nom. inv., since documented with only a single relevé, was not analyzed, but most probably belongs to the same group of syntaxa. The stands of the association Seslerio robustae-Juniperetum alpinae from the Biokovo mountain range in central Dalmatia, structurally similar, but floristically quite distinct, synsystematically better fit within the class Festuco-Brometea than Erico-Pinetea or even Vaccinio-Piceetea (for further discussion see TrinaJstić 1987) and to ascertain their syntaxonomic position more accurately would require much more comprehensive analyses comparing syntaxa not only of two, but three or four classes. Being aware that their syntaxonomic position is not entirely clear we followed the proposal of TRINAJSTIĆ (1987, 2008), although Sedlar and co-workers placed similar stands with Pinus nigra subsp. dalmatica dominating in a tree layer within the class Pino-Juniperetea (SEDLAR et al. 2011).

Although resolving the syntaxonomy of mountain pine scrubs communities was far beyond the scope of the present paper, the results of our preliminary analyses showed a certain (phyto)geographical structure (Fig. 3c), where Dinaric stands represented a distinct group of syntaxa in all of the performed analyses. However, only a thorough synoptic approach taking into account all the south-eastern-European stands of the Mountain pine would properly challenge their current syntaxonomy.

\section{Acknowledgements}

We thank friends and colleagues Andraž Žnidaršič (Slovenia Forest Service, Slovenia), Andrej Radalj (The Jezero Society, Croatia) for the help during the field work and Željka Modrić Surina (Natural History Museum Rijeka, Croatia), Marko Randić (Public Institution »Priroda «, Croatia), Igor Dakskobler (Science and Research Centre of the Slovenian Academy of Sciences and Arts, Slovenia), Academ. Mitja Zupančič (Slovenian Academy of Sciences and Arts, Slovenia), Emerit. Livio Poldini (University of Trieste, Italy), Romeo di Pietro (Sapienza University of Rome, Italy), Vladimir Hršak and Joco Vukelić (University of Zagreb, Croatia) for fruitful discussions on syntaxonomy of heaths. Special thanks go to Igor Dakskobler for valuable comments and discussions on nomenclatorial issues, while Željka Modrić Surina commented on a previous version of the manuscript. The research was financially supported by the Public Institution »Priroda« (project no. 112-07/11-02/01 -2170-52-01/1-11-19).

\section{References}

Aeschimann, D., Lauber, K., Mosser, D. M., Theurillat, J.-P., 2004: Flora alpina, 1-3. Haupt Verlag, Bern, Stuttgart, Wien. 
BiLlings, W. D., Bliss, L. C., 1959: An alpine snowbank environment and its effects on vegetation, plant developlent, and productivity. Ecology 40, 388-397.

BJELČIĆ, Ž., 1966: Vegetation of the subalpine belt of Mt. Jahorina (in Serbian). Glasnik Zemaljskog muzeja Bosne i Hercegovine u Sarajevu 5, 31-104.

BLEČIć, V., 1957: Contribution to the knowledge of forest vegetation of Mt. Ljubišnja (in Serbian). Glasnik prirodnjačkog muzeja Srpske zemlje, Serija B 10, 25-42.

BLEČIĆ, V., 1958: Forest, scree and rock crevices vegetation of the Piva valley (in Serbian). Glasnik prirodnjačkog muzeja u Beogradu, Serija B, 1-108.

BraAk Ter, J. F. C., Šmilauer, P., 2002: CANOCO Reference manual and CanoDraw for Windows. User's guide to Canoco for Windows: Software for Canonical Community Ordination (version 4.5). Microcomputer Power (Ithaca, NY, USA), New York.

Braun-Blanquet, J., 1928: Pflanzensoziologie. Springer, Berlin.

Braun-Blanquet, J., 1931: Aperçu des groupements végétaux du Bas-Languedoc. Communication S.I.G.M.A. 9, Montpellier.

CEROVEČKI, Z., 2009: Beech forests and milava - As. Calamagrosti arundinaceae-Fagetum (Ht. 1950) Cerovčki as. nov. of the mountain of west Croatia (in Croatian). Šumarski List 133, 417-423

DAKSKOBLER, I., 2006: The association Rhodothamno-Laricetum (Zukrigl 1973) Willner \& Zukrigl 1999 in the Julian Alps (in Slovenian). Razprave 4 Razreda SAZU 57, 117-192.

DierschKe, H., 1994: Pflanzensoziologie. Eugen Ulmer Verlag, Stuttgart.

Domac, R., 1962: Dalmatian Pine (Pinus dalmatica Vis. s.1.) forests on Mt. Biokovo (in Croatian). Acta Botanica Croatica 20-21, 203-223.

Hammer, O., Harper, D. A. T., Ryan, P. D., 2001: Paleontological Statistics Software Package for Education and Data Analysis. Palaeontologia Electronica 4, 1-9.

HoRvat, I., 1930: Vegetation studies in mountains of Croatia. I. Tussoc grassland communities (in Croatian). Rad Jugoslavenske Akademije Znanosti i Umjetnosti 238, 1-96.

HoRvat, I., 1931: Vegetation studies in mountains of Croatia. II. Scree and rock-crevices communities (in Croatian). Rad Jugoslavenske Akademije Znanosti i Umjetnosti 241, 147-206.

HoRvat, I., 1938: Phytosociological research of forests in Croatia (in Croatian). Glasnik za šumske pokuse $6,127-256$.

HoRvat, I., 1962: Mountain vegetation of west Croatia (in Croatian). Acta Biologica II 30, $1-179$.

Horvat, I., Glavać, V., Ellenberg, H., 1974: Vegetation Südosteuropas. Gustav Fischer Verlag, Stuttgart.

LAKUŠIĆ, R., 1966: Grassland vegetation of Mt. Bjelasica (in Serbian). Godišnjak Biološkog Instituta u Sarajevu 19, 25-186.

Lakušić, R., Pavlović, D., ABadžIć, S., Kutleša, L., Mišıć, Lj., RedžIć, S., Maljević, D., Bratović, S., 1979: Ecosystems structure and dynamics on Mt. Vranica in Bosnia (in Serbian). In: RAUš, Du. (ed.), Proceedings 2 Congress of Jugoslavian Ecologists I, 605-714. Savez društava ekologa Jugoslavije, Zagreb.

LEPŠ, J., Šmilauer, P., 2003: Multivariate analysis of ecological data using CANOCO. Cambridge University Press, Cambridge. 
MARTINČIČ, A., 1977: Contribution to the knowledge of the ecology of freezing dolines in Slovenia (in Slovenian). Razprave IV.razreda SAZU 20, 231-316.

Martinčič, A., Wraber, T., Jogan, N., Podobnik, A., Turk, B., Vreš, B., RaVnik, V., FraJman, B., Strgulc KrajšEK, S., TrČAK, B., BačIČ, T., Fischer, M. A., Eler, K., Surina, B., 2007: Small flora of Slovenia. Identification key of vascular plants (in Slovenian). Tehniška založba Slovenije, Ljubljana.

Modrić SurinA, Ž., SuRINA, B., 2010: Snowbed vegetation in Croatia: phytosociology, ecology and conservation status. Plant Biosystems 144, 747-768.

Pignatti, S., 2005: Valori di bioindicazione delle piante vascolari della flora d'Italia. Braun-Blanquetia 39, 1-97.

Poldini, L., Oriolo, G., Francescato, C., 2004: Mountain pine scrubs and heaths with Ericaceae in the south-eastern Alps. Plant Biosystems 138, 53-85.

Randić, M., 2009: Obruč. In: Nikolić, T., Topić, J., Vuković, N. (eds.), Importan plant areas - Croatia (in Croatian), 395-400. Prirodoslovno-matematički fakultet Sveučilišta u Zagrebu i Školska knjiga, Zagreb.

SEDLAR, Z., HRŠAK, V., ŠOŠTARIĆ, R., 2011: Numerical and phytosociological analysis of the Junipero sibiricae-Pinetum dalmaticae Domac (1956) 1965 association and comparison to Mediterranean forests dominated by Pinus nigra Arn. s.l. Šumarski List 85, $139-152$.

STANISCI, A., 1997: Gli arbusteti altimontani dell' Appennino centrale e meridionale. Fitosociologia 34, 3-46.

SuRINA, B., 2005: Subalpine and alpine vegetation of the Krn area in the Julian Alps. Scopolia 57, 1-222.

Surina, B., RAKAJ, M., 2007: Subalpine beech forest with hairy alpenrose (Polysticho lonchitis-Fagetum rhododendretosum hirsuti subass. nova) on Mt. Snežnik (Liburnian karst, Dinaric Mts). Hacquetia 6, 89-102.

SuRINA, B., VREŠ, B., 2004: Phytsociological characteristics of sites of Heliosperma pusillum (=Silene pusilla, Caryophyllaceae) in the freezing ravines on the Snežnik Plateau (SW Slovenia). Razprave 4 razreda SAZU 45, 147-183.

SuRINA, B., VREŠ, B., 2009: The association Drepanoclado uncinati-Heliospermetum pusilli (Arabidetalia caeruleae, Thlaspietea rotundifolii) in the Trnovski gozd plateau (Slovenia, NW Dinaric Mts). Hacquetia 8, 31-40.

Theurillat, J.-P., Aeschimann, D., KüPfER, P., SpIChiger, R., 1995: The higher vegetation units of the Alps. Colloques phytosociologiques 23, 189-239.

TrinAJstić, I., 1987: A sintaksonomic overview of plant communities on Mt. Biokovo (in Croatian). Acta Biokovica 4, 143-174.

TRINAJSTIĆ, I., 2008: Plant communities of Croatia. Akademija šumarskih znanosti, Zagreb.

VAN DER MAAREL, E., 1979: Transformation of cover-abundance values in phytosociology and its effects on community similarity. Vegetatio 39, 97-114.

VRDOLJAK, Ž., 1983: Contribution to the knowledge of forest vegetation of Mt. Biokovo (in Croatian). Acta Biokovica 2, 247-282. 
Vukelić, J., Mikac, S., Baričević, D., BaKšić, D., Rosavec, R., 2008: Forest Sites and Forest Communities in Croatia. National Ecological Network. State Institute of Nature Protection, Zagreb.

WallnöFer, S., 1993b: Erico-Pinetea. In: Grabherr, G., Greimler, J., Mucina, L. (eds.), Die Pflanzengesellschaften Österreichs, 3, Wälder und Gebüsche, 244-282. Fischer Verlag, Jena-Stuttgart-New York.

WallnöFer, S., 1993a: Vaccinio-Piceetea. In: Grabherr, G., Greimler, J., Mucina, L. (eds.), Die Pflanzengesellschaften Österreichs, 3, Wälder und Gebüsche, 283-337. Fischer Verlag, Jena-Stuttgart-New York.

Weber, H. E., Moravec, J., Theurillat, J.-P., 2000: International Code of Phytosociological Nomenclature, 3. Journal of Vegetation Science 11, 739-768.

Westhoff, V., VAN DER MAAREL, E., 1973: The Braun-Blanquet approach. In: WhitTAKER, R. H. (ed.), Ordination and classification of communities. Handbook of Vegetation Science 5, 619-726. Dr. W. Junk b.v. Publishers, The Hague.

Wraber, T., 1997: Bupleurum exaltatum, Mt. Snežnik and - (?) sheeps (in Slovenian). Proteus 59, 374-377.

ZUPANČIČ, M., WrABER, T., ŽAGAR, V., 2004: Dinaric mountain pine association Hyperico grisebachii-Pinetum mugo on Mt. Snežnik (in Slovenian). Razprave 4 razreda SAZU 45, 185-261.

ZupančIČ, M., ŽAgar, V., Culiberg, M., 2006: Slovene Alpine Pinus mugo scrub in comparison with European Pinus mugo scrab. Dela 4 razreda SAZU 40, 1-111.

Appendix I - phytosociological and site parameters of relevés in table 1 (rel. no. and field no., altitude, exposition, inclination, coverage: $\mathrm{S}$ - stoniness, $\mathrm{C}$ - herb layer

1-8 - Mt. Snežnik, 9-22 - Mt. Obruč

1 (20111004/07), 1413 m, NNE, $36 \mathrm{~m}^{2}, 20^{\circ}$, S 40\%, C 60\%, leg. A. Radalj et B. Surina; 2 (20111004/08), 1412 m, SE, $36 \mathrm{~m}^{2}, 10^{0}, \mathrm{~S} \mathrm{60 \% ,} \mathrm{C} \mathrm{40 \% ,} \mathrm{leg.} \mathrm{A.} \mathrm{Radalj} \mathrm{et} \mathrm{B.} \mathrm{Surina;} 3$ (20111004/04), 1390 m, S, $36 \mathrm{~m}^{2}, 25^{0}$, S 60\%, C 40\%, leg. A. Radalj et B. Surina; 4 (20111004/03), 1375 m, NNE, $30 \mathrm{~m}^{2}, 35^{0}$, S 20\%, C 80\%, leg. A. Radalj et B. Surina; 5 (20111004/05), 1400 m, E, $25 \mathrm{~m}^{2}, 40^{0}$, S 30\%, C 70\%, leg. A. Radalj et B. Surina; 6 (20111004/01), $1391 \mathrm{~m}, \mathrm{E}, 20 \mathrm{~m}^{2}, 40^{\circ}$, S 50\%, C 50\%, leg. A. Radalj et B. Surina; 7 (20111004/02), 1400 m, NNE, $25 \mathrm{~m}^{2}, 60^{\circ}$, S 40\%, C 60\%, leg. A. Radalj et B. Surina; 8 (20050724/05), 1340 m, S, $25 \mathrm{~m}^{2}, 20^{0}$, S 30\%, C 70\%, leg. A. Žnidaršič et B. Surina; 9 (20111004/06), 1350 m, NNE, $50 \mathrm{~m}^{2}, 30^{\circ}$, S 40\%, C 60\%, leg. A. Radalj et B. Surina; 10 (20110907/08), 1242 m, ESE, $36 \mathrm{~m}^{2}, 30$, S 40\%, C 60\%, leg. B. Surina; 11 (20110907/12), 1220 m, E, $30 \mathrm{~m}^{2}, 35^{0}$, S 60\%, C 40\%, leg. B. Surina; 12 (20110907/11), 1260 m, NNE, 30 $\mathrm{m}^{2}, 30^{0}$, S 40\%, C 60\%, leg. B. Surina; 13 (20110907/07), 1239 m, N, $25 \mathrm{~m}^{2}, 30^{\circ}$, S 30\%, C $70 \%$, leg. B. Surina; 14 (20110907/06), 1243 m, NNE, $20 \mathrm{~m}^{2}, 30^{0}$, S 40\%, C 60\%, leg. B. 
Surina; 15 (20110907/10), $1248 \mathrm{~m}, \mathrm{~N}, 25 \mathrm{~m}^{2}, 40 \%$, S 50\%, C 50\%, leg. B. Surina; 16 (20110830/10), 1260 m, NNE, $30 \mathrm{~m}^{2}, 25^{0}$, S 60\%, C 40\%, leg. Ž. Modrić Surina et B. Surina; 17 (20110907/05), 1252 m, ENE, $30 \mathrm{~m}^{2}, 30^{0}$, S 60\%, C 40\%, leg. B. Surina; 18 (20110907/09), 1244 m, NNE, $25 \mathrm{~m}^{2}, 35^{0}$, S 60\%, C 40\%, leg. B. Surina; 19 (20110907/04), $1260 \mathrm{~m}, \mathrm{NE}, 50 \mathrm{~m}^{2}, 25^{\circ}$, S 50\%, C 50\%, leg. B. Surina; 20 (20110907/01), $1255 \mathrm{~m}$, ENE, 20 $\mathrm{m}^{2}, 30^{\circ}$, S 40\%, C 60\%, leg. B. Surina; 21 (20110907/02), $1246 \mathrm{~m}$, ENE, $30 \mathrm{~m}^{2}, 35^{\circ}$, S 30\%, C 70\%, leg. B. Surina; 22 (20110907/03), 1250 m, NE, $36 \mathrm{~m}^{2}, 40^{\circ}$, S 40\%, C 60\%, leg. B. Surina.

\section{Appendix II - taxa occurring once in table 1}

Erico-Pinetea: Arctostaphyllos uva-ursi 1 (12), Gymnadenia conopsea + (18), Peucedanum austriacum s.l. + (8); Vaccinio-Piceetea: Huperzia selago + (4), Luzula sylvatica + (4); Fagetalia sylvaticae (incl. Aremonio-Fagion*): Hacquetia epipactis* + (8), Euphorbia carniolica + (8), Melica nutans + (8), Dryopteris filix-mas + (9), Scrophularia nodosa + (9), Acer pseudoplatanus + (13); Querco-Fagetea (incl. Quercetalia pubescentis*): Melittis melissophyllum* + (9), Hepatica nobilis + (8); Trifolio-Geranietea: Ligusticum seguerii 2 (11); Thlaspietea rotundifolii: Petasites paradoxus 2 (18), Dryopteris submontana 1 (9), Festuca nitida 1 (9), Scrophularia laciniata $+(10)$, Trisetum argenteum $+(4) ;$ Asplenietea trichomanis: Asplenium fissum + (6), Kernera saxatilis $+(6)$, Cystopteris fragilis $+(9)$; Mulgedio-Aconitetea: Viola biflora + (6), Aconitum ranunculifolium + (9), Hypericum maculatum ssp. maculatum + (9), Veratrum album s.1. + (3), Tephroseris ovirensis + (4); Elyno-Seslerietea: Polygala alpestris ssp. croatica $+(20)$; Festuco-Brometea: Teucrium montanum + (10), Ruta divaricata 1 (10); Molinio-Arrhenatheretea: Leontodon hispidus 1 (4).

\section{Appendix III - list of syntaxa mentioned in text and table 1}

Amelanchiero-Pinetum mugo Minghetti in Pedroti 1994; Aquilegio nigricantis-Rhododendretum hirsuti Lakušić et al. ex Surina ass. nova hoc loco (=Aquilegio-Rhododendretum hirsuti Lakušić et al. 1979 nom. inv.); Arctostaphylletum uvae-ursi Lakušić et al. 1979 nom. inv:; Aremonio-Fagion (Horvat 1938) Borhidi in Török, Podani et Borhidi 1989; Asplenietea trichomanis Br.-Bl. in Meier et Br.-B1. 1934; Berberido creticae-Juniperion foetidissimae Brullo et al. 2001; Calamagrostido arundinaceae-Fagetum Cerovečki 2009; Calamagrostido variae-Abietetum Horvat 1950 piceetosum; Carici humilis-Centaureetum rupestris Horvat 1931 seslerietosum tenuifoliae Horvat 1962 nom. nud.; Doronico austriaci-Adenostyletum alliariae Horvat ex Horvat 1974;

Drepanoclado uncinati-Heliospermetum pusilli Surina et Vreš 2004; Elyno-Seslerietea Br.-B1. 1948; Ericetum carneae Rübel 1911; Ericion carneae Rübel ex Grabherr et al. 1993; Erico carneae-Pinetum prostratae Zötl 1951 nom. inv.; Erico-Pinetea Horvat 1959; Erico-Pinetalia Horvat 1959; Fagetalia sylvaticae Pawlowski in Pawlowski et al. 1928; Festuco-Brometea Br.-Bl. et Tx. 1943; Festuco alpestris-Genistetum radiatae Peer ex Poldini et al. 2004; Hacquetio-Piceetum Zupančič (1980) 1999; Hyperico maculati-Vaccinietum myrtilli Lakušić et al. ex Surina ass. nova hoc loco (=Hyperici-Vaccinietum bosniacum Lakušić et al. 1979 nom. inv.); Hyperico grisebachii-Vaccinietum myrtilli Lakušić ex Surina ass. nova hoc loco (=Hyperici-Vaccinietum montenegrinum Lakušić 1966 nom. inv.); 
Hyperico grisebachii-Pinetum mugo Wraber et al. in Zupančič et al. 2004 var. geogr. Arabis scopoliana (=Pinetum mughi croaticum Horvat 1938 p.p.; Pinetum mughi montenegrinum Blečić 1957 nom. inv.); Juniperetalia haemisphaericae Rivas-Martinez et Molina 1999; Junipero sibiricae-Semperviretum schlechanii Bjelčić 1966 (=Sempervivo schlechanii-Juniperetum sibiricae Bjelčić 1966 nom. invers. prop.); Lonicero caeruleae-Piceetum Zupančič (1980) 1999; Loiseleurio-Vaccinietea Eggler ex Schubert 1960; Mulgedio-Aconitetea Hadač et Klika in Klika et Hadač 1944; Molinio-Arrhenatheretea R. Tx. 1937 em. R. Tx. 1970; Omphalodo-Fagetum (Tregubov 1957 corr. Puncer 1980) Marinček et al. 1993 var. geogr. Calamintha grandiflora Surina 2001 seslerietosum autumnalis nom. nud. (=Fagetum croaticum australe abietetosum Horvat 1938, Abieti-Fagetum dinaricum Tregubov 1957); Piceetalia excelsae Pawlowski in Pawlowski et al. 1928; Pinetum mughi Illyricum Lakušić et al. 1979 nom. inv.; Pino-Juniperetea Rivas-Martinez 1964; Polysticho lonchitis-Fagetum (Horvat 1938) Marinček in Poldini et Nardini 1993 (=Fagetum croaticum australe subalpinum Horvat 1938) rhododendretosum hirsuti Surina et Rakaj 2007; Poo alpinae-Trisetalia Ellmauer et Mucina 1993; Quercetalia pubscentis Klika 1933; Querco-Fagetea Br.-B1. et Vlieg. 1937; Rhododendretum ferruginei Rübel 1911; Rhododendro ferruginei-Pinetum prostratae Zötl 1951 nom. inv.; Rhododendro hirsuti-Juniperetum sibiricae Horvat ex Horvat et al. 1974 (=Rhododendro hirsuti-Juniperetum sibiricae Horvat 1962 nom. nud.); Rhododendro hirsuti-Pinetum prostratae Zötl 1951 nom. inv.; Rhododendro hirsuti-Salicetum appendiculatae Tomažič nom. nud. (=Salicetum appendiculatae Horvat ex Horvat et al. 1974); Rhododendro-Vaccinion (Br.-Bl. in Br.-Bl. et Jenny 1926) Br.-Bl. 1948; Rhodothamno chamaecisti-Juniperetum alpini Poldini et al. 2004; Roso-Juniperetum nanae Lakušić 1966 (=Roso pendulinae-Juniperetum sibiricae Lakušić 1966 nom. corr.); Roso pendulinae-Pinetea mugi Theurillat in Theurillat et al. 1995; Satureion subspicatae Horvat 1962; Scorzonero-Chrysopogonetalia Horvatić et Horvat (1956) 1958; Seslerio autumnalis-Fagetum (Horvat 1938) M. Wraber ex Borhidi 1963 (=Fagetum croaticum australe seslerietosum autumnalis Horvat 1938); Seslerion tenuifoliae Horvat 1962; Seslerietea albicantis Oberdorfer 1978 corr. Oberdorfer 1990; Seslerio robustae-Juniperetum sibiricae Domac 1962; Sorbo chamaemespili-Pinetum mugo Minghetti 1996; Thlaspietea rotundifolii Br.-Bl. in Br.-Bl. et Jenny 1926; Trifolio-Geranietea Th. Mueller 1961; Vaccinio myrtilli-Callunetum vulgaris Lakušić et al. ex Surina ass. nova hoc loco (Vaccinio-Callunetum subalpinum Lakušić et al. 1979 nom. inv.); Vaccinio-Piceetea Br.-Bl. 1939 emend. Zupančič (1976) 2000; Vaccinio vitis-ideae-Callunetum vulgaris Poldini et al. 2004. 


\title{
Chemical composition and antioxidant potential of Acacia leucophloea Roxb.
}

\author{
MuHAMMAD Zia-Ul-HaQ ${ }^{1}$, SANJA ĆAVAR ${ }^{2, *}$, Mughal QAYUM ${ }^{3}$, \\ INAMULLAH KHAN ${ }^{4}$, SHAKEEL AHMAD ${ }^{5}$ \\ ${ }^{1}$ Research Institute of Pharmaceutical Sciences, Department of Pharmacognosy, \\ University of Karachi, Karachi 75270, Pakistan \\ ${ }^{2}$ University of Sarajevo, Faculty of Science, Department of Chemistry, \\ 71000 Sarajevo, Bosnia and Herzegovina \\ ${ }^{3}$ Department of Pharmacy, Kohat University of Science and Technology, Kohat 2600, \\ Pakistan \\ ${ }^{4}$ Department of Pharmacy, University of Peshawar, Peshawar 25120, Pakistan \\ ${ }^{5}$ Department of Agronomy, Bahauddin Zakariya University, Multan 60800, Pakistan
}

\begin{abstract}
The aim of this study was to evaluate the compositional and nutritional potential of methanolic extracts of various parts of Acacia leucophloea Roxb. concerning the chemical composition and antioxidant potential of which limited information is available. Compositional studies indicated carbohydrates as major components in both seed and pods. Despite differences in mineral content among the leaves, pods and seeds, calcium was found in the highest amount and zinc in the lowest. The amino acid profile indicated aspartic acid as the major amino acid and proline as the minor. Among protein fractions, globulin was present in higher amounts than other fractions. Linoleic acid was the major fatty acid detected in the oil from both pods and seeds, while $\gamma$-tocopherol was the major component of the tocopherol observed from same oil. Moreover, significant antioxidant potential was observed from the extracts of all three parts investigated. The results obtained in this study clearly indicate that A. leucophloea has a sufficient potential for use as a natural antioxidant agent. Further phytochemical studies will be performed for specification of the biologically active principles.
\end{abstract}

Key words: Acacia leucophloea, mineral content, amino acids, fatty acids, tocopherols, sterols, antioxidant activity
Abbreviations:
AOAC - Association of Official Analytical Chemists; BHA - butylated hydroxy anisole; BHT - butylated hydroxy toluene; FRAP - ferric reducing antioxidant power; ROS - re- active oxygen species; TAC - total antioxidant capacity; TEAC - Trolox equivalent anti- oxidant capacity; TRAP - radical-trapping antioxidant parameter.

* Corresponding author, e-mail: sanja_cavar@yahoo.com

Copyright ${ }^{\circledR} 2013$ by Acta Botanica Croatica, the Faculty of Science, University of Zagreb. All rights reserved. 